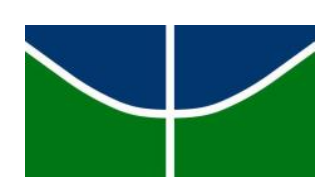

UNIVERSIDADE DE BRASÍLIA - UnB

INSTITUTO DE LETRAS - IL

DEPARTAMENTO DE LINGUÍSTICA, PORTUGUÊS E LÍNGUAS CLÁSSICAS-LIP PROGRAMA DE PÓS-GRADUAÇÃO EM LINGUÍSTICA - PPGL

\title{
ATIVIDADES DE COMPREENSÃO TEXTUAL NO ENSINO TÉCNICO: ESTUDO SOCIOINTERACIONAL DE PROCESSOS INFERENCIAIS
}

ALINNE SANTANA FERREIRA 
UNIVERSIDADE DE BRASÍLIA - UnB

INSTITUTO DE LETRAS - IL

DEPARTAMENTO DE LINGUÍSTICA, PORTUGUÊS E LÍNGUAS CLÁSSICAS-LIP PROGRAMA DE PÓS-GRADUAÇÃO EM LINGUÍSTICA - PPGL

\section{Alinne Santana Ferreira}

\section{ATIVIDADES DE COMPREENSÃO TEXTUAL NO ENSINO TÉCNICO: ESTUDO SOCIOINTERACIONAL DE PROCESSOS INFERENCIAIS}

Tese apresentada ao Programa de Pós-Graduação em Linguística, Departamento de Linguística, Português e Línguas Clássicas, Instituto de Letras, Universidade de Brasília, como requisito parcial para obtenção do Grau de Doutora em Linguística.

Área de concentração: Linguagem e Sociedade.

Orientadora: Prof ${ }^{a}$. Doutora Cibele Brandão de Oliveira

Brasília - DF, dezembro de 2016. 
Ficha catalográfica elaborada automaticamente, com os dados fornecidos pelo(a) autor(a)

\section{FERREIRA, ALINNE SANTANA}

FF383a

ATIVIDADES DE COMPREENSÃO TEXTUAL NO ENSINO TÉCNICO: ESTUDO SOCIOINTERACIONAL DE PROCESSOS INFERENCIAIS / ALINNE SANTANA FERREIRA; orientador CIBELE BRANDÃO. - - Brasília, 2016.

$234 \mathrm{p}$.

Tese (Doutorado - Doutorado em Linguística) -Universidade de Brasília, 2016.

1. Processos inferenciais. 2. Compreensão textual. 3. Letramentos críticos no ensino técnico. 4. Proposta didática para ensino da leitura. I. BRANDÃO, CIBELE, orient. II. Título. 


\title{
ATIVIDADES DE COMPREENSÃO TEXTUAL NO ENSINO TÉCNICO: ESTUDO SOCIOINTERACIONAL DE PROCESSOS INFERENCIAIS
}

\author{
Tese apresentada ao Programa de Pós-Graduação em \\ Linguística, Departamento de Linguística, Português e \\ Línguas Clássicas, Instituto de Letras, Universidade de \\ Brasília, como requisito parcial para obtenção do Grau de \\ Doutora em Linguística. \\ Área de concentração: Linguagem e Sociedade.
}

\section{Banca Examinadora:}

Prof $^{\mathrm{a}}$. Doutora Cibele Brandão de Oliveira (Orientadora /Presidente)

Programa de Pós-Graduação em Linguística - Universidade de Brasília (PPGL/UnB)

Prof $^{\mathrm{a}}$. Doutora Mônica Magalhães Cavalcante (Membro Externo)

Departamento de Letras Vernáculas - Universidade Federal do Ceará (UFC)

Prof $^{\text {a }}$. Doutora Maria da Penha Pereira Lins (Membro Externo)

Departamento de Línguas e Letras - Universidade Federal do Espírito Santo (UFES)

Prof $^{\text {a }}$. Doutora Maria Luiza Monteiro Sales Corôa (Membro Interno)

Programa de Pós-Graduação em Linguística - Universidade de Brasília (PPGL/UnB)

Prof $^{\text {a }}$. Doutora Ana Adelina Lôpo Ramos (Membro Interno)

Programa de Pós-Graduação em Linguística - Universidade de Brasília (PPGL/UnB)

Prof. Doutor Rodrigo Albuquerque Pereira (Suplente)

Programa de Pós-Graduação em Linguística - Universidade de Brasília (PPGL/UnB) 
A minha mãe, minha inspiração para tudo o que há de mais lindo no mundo. A meu esposo Edwin, amor, amigo e companheiro em todas as horas. 


\section{AGRADECIMENTOS}

À Deus, razão de ser de todas as coisas.

Ao Mestre Jesus e a meus amigos espirituais, pela inspiração e companhia em todos os instantes.

A meus pais e a minha irmã, por sempre me mostrarem a importância do estudo e do trabalho.

A meu sobrinho Heitor, minha luz e alegria.

A todos os meus familiares pelo apoio e pelas orações, compreendendo, mesmo com tristeza, minha ausência em razão dos estudos.

Aos meus colegas e amigos do Instituto Federal de Brasília, que me apoiaram desde a realização da seleção do doutorado até a efetivação do meu afastamento para concluir o curso.

Aos colegas que encontrei no Programa de Pós-Graduação em Linguística da UnB, pelas conversas e produções que tanto enriqueceram meu saber e minha identidade de pesquisadora.

Às amigas, parceiras de todas as horas, Regysane, Adriane e Luciane, pelas conversas, risadas e conselhos e pelas revisões no texto deste trabalho.

Aos professores do Programa de Pós-graduação em Linguística com os quais tive a honra de conviver participando das aulas e de outros momentos de interlocução que abrilhantaram minha formação no mestrado e no doutorado.

A minha orientadora, professora $\mathrm{Dr}^{\mathrm{a}}$. Cibele Brandão, pela competência, seriedade e compromisso. Sou grata pela oportunidade de ter convivido com ela e aprendido muito durante os anos do mestrado e do doutorado.

À professora Dra ${ }^{\mathrm{a}}$. Maria Luiza Corôa, pelas excelentes contribuições no exame de qualificação, que propiciaram novos rumos a este trabalho e pelas inesquecíveis aulas de Semântica e de Análise do Discurso e Ensino.

À professora Dra ${ }^{a}$. Edwiges Morato, pelas valiosas contribuições realizadas no exame de qualificação.

Às professoras $\mathrm{Dr}^{\mathrm{a}}{ }^{\mathrm{a}}$. Maria Luiza Corôa, Ana Adelina Lôpo Ramos, Mônica Magalhães Cavalcante, Maria da Penha Pereira Lins e ao professor Dr. Rodrigo Albuquerque Pereira, pela gentileza em terem aceitado o convite para participar de minha banca de doutorado. 
Às queridas amigas Cíntia e Regysane, pela tradução do resumo deste trabalho para o Espanhol e para o Inglês, respectivamente.

À amiga Eneida, que tão gentilmente cedeu seis aulas em sua turma do $1^{\circ}$ módulo do Técnico Subsequente em Secretariado Escolar para que eu pudesse realizar a geração dos dados desta pesquisa.

Aos queridos alunos do primeiro módulo do curso Técnico Subsequente em Secretariado Escolar, do Instituto Federal de Brasília - IFB, campus São Sebastião, por terem me acolhido de forma tão amorosa e por permitirem que os dados fossem gerados e transformados neste estudo.

Ao Instituto Federal de Brasília - IFB, pela concessão de licença para capacitação, a partir do segundo ano de curso, que me permitiu dedicação integral aos estudos doutorais. 
O DIÁLOGO É O ENCONTRO ENTRE OS HOMENS, MEDIATIZADOS PELO MUNDO, PARA DESIGNÁ-LO. SE AO DIZER SUAS PALAVRAS, AO CHAMAR AO MUNDO, OS HOMENS O TRANSFORMAM, O DIÁLOGO IMPÕE-SE COMO O CAMINHO PELO QUAL OS HOMENS ENCONTRAM SEU SIGNIFICADO ENQUANTO HOMENS; O DIÁLOGO É, POIS, UMA NECESSIDADE EXISTENCIAL.

(PAULO FREIRE, 1979, p.82) 
Este estudo investigou os processos inferenciais em atividades de compreensão textual em uma turma do curso técnico em secretariado escolar do Instituto Federal de Brasília - IFB, campus São Sebastião - DF. Os dados foram gerados por meio de pesquisa-ação participativa crítica, na qual a pesquisadora atuou como professora da turma, gravando áudios e imagens das atividades realizadas. A base teórica do trabalho é orientada pela Sociolinguística Interacional (Goffman ([1964]2002; Gumperz, 1982a e b e Tannen, 2004), pois nele são analisados os significados sociais que emergem das interações face a face e investigam-se práticas sociais contextualmente situadas. A Linguística Textual ofereceu embasamento referente aos conceitos de texto, gêneros textuais, referenciação e inferenciação, fundamentais para as referências deste estudo na construção do arcabouço teórico, que deu suporte para análise de dados. Nessa perspectiva, o texto é compreendido como atividade sociodiscursiva (KOCH \& MARCUSCHI, 1998), em que a referenciação e a inferenciação constituem processos sociodiscursivos. Por essa razão, os estudos de Vygotsky ([1934]2001 e 1997) sobre pensamento, linguagem, aprendizagem e desenvolvimento, bem como os de Tomasello ([1999]2003, 2008 e 2009) acerca da filogênese, da ontogênese e da sociogênese humanas foram acrescidos aos fundamentos teóricos deste estudo. Também foi necessário abordar o letramento na perspectiva ideológica (BARTON, 1994 e STREET 1984, 1993 e 2014), uma vez que os colaboradores desta pesquisa tiveram a oportunidade de refletir sobre os significados das práticas que vivenciaram em sala de aula. A Andragogia (LUDOJOSKI, 1972 e KNOWLES, 1973), área que estuda as práticas educacionais voltadas ao público adulto, também foi tratada, pois os ensinamentos dessa disciplina auxiliam professores de cursos técnicos subsequentes a conhecerem seu público, formado majoritariamente por estudantes adultos. A metodologia empregada para a construção do corpus desta pesquisa teve na etnografia colaborativa de sala de aula o alicerce para o emprego da pesquisa-ação participativa crítica (KEMMIS \& McTAGGART, 2005) como método utilizado em pesquisas educacionais que objetivem transformações no contexto pesquisado. Como forma de triangular os dados, realizou-se grupo focal (MORGAN, 1977 e BARBOUR, 2009) para investigar as representações dos alunos em relação às atividades realizadas durante as aulas. Os resultados deste estudo indicam que os processos inferenciais foram construídos durante a realização de atividades de produção textual compreensiva e nas interações face a face que ocorreram durante as atividades de leitura coletiva. Foram revelados quatro processos inferenciais: (1) uso de metáforas; (2) utilização de narrativas; (3) uso de expressões referenciais e (4) realização de inferências conversacionais. Além desses resultados, constatou-se que as atividades de leitura em sala de aula devem ser pensadas previamente pelo professor, por meio da escolha de gêneros textuais coerentes com os objetivos da aula e da elaboração de atividades individuais nas quais os alunos possam refletir previamente sobre $\mathrm{o}(\mathrm{s})$ textos(s) trabalhado(s) para que, posteriormente, eles ampliem as inferências nos momentos de interação com o professor e com os colegas, a fim de construírem letramentos críticos. Este estudo foi transformado em proposta didática que pretende orientar as práticas de leitura realizadas por professores dos cursos técnicos subsequentes.

Palavras-chave: Processos inferenciais. Compreensão textual. Letramentos críticos no ensino técnico. Proposta didática para ensino da leitura. 
This study investigated the inferential processes in text comprehension activities of a class of subsequent technical school secretarial course in the Instituto Federal de Brasília - IFB, São Sebastião campus - DF. Data were generated through a participatory action research, in which the researcher acted as the group's teacher, recording the audio and images of the activities. The theoretical basis of the work is guided by Interactional Sociolinguistics (GOFFMAN ([1964] 2002; GUMPERZ 1982a and b; and TANNEN, 2004), according to which we analyzed the social meanings that emerge from face to face interactions, and investigated contextually situated social practices. Textual Linguistics offered the basis regarding the concepts of text, genres, and reference and inference processes, that are fundamental to this study's references in building the theoretical framework that supported data analysis. In this perspective, text is understood as a sociodiscursive activity (KOCH \& MARCUSCHI, 1998), wherein the reference and inference processes constitute sociodiscursive processes. Because of this, Vygotsky's studies ([1934] 2001 and 1997) on thinking, language, learning and development, as well as Tomasello's ones ([1999] 2003, 2008 and 2009) on phylogeny, ontogenesis and human sociogenesis were added to the theoretical foundations of this study. It was also necessary to address literacy in the ideological perspective (BARTON, 1994; and STREET 1984, 1993 and 2014), since the collaborators of this research had the opportunity to think about the meanings of the practices they had experienced in classroom. Andragogy (LUDOJOSKI, 1972 and KNOWLES, 1973), area that studies the educational practices aimed at an adult audience, was also considered, because the teachings of this discipline help teachers of subsequent technical courses to know their audience, which is mainly constituted by adult students. The methodology used to build the corpus of this research has its foundation on the classroom collaborative ethnography which was the basis for the implementation of the critical participatory action research (KEMMIS \& McTAGGART, 2005) as a method used in educational research whose goals are transformations in the investigated context. For data triangulation, we conducted a focus group (MORGAN, 1977; and BARBOUR, 2009) to investigate students' representations regarding the activities undertaken during the classes. This study's results indicate that inferential processes were constructed during comprehensive textual production activities and in face to face interactions that occurred during the collective reading activities. Four inferential processes were revealed: (1) use of metaphors; (2) use of narratives; (3) use of referential expressions; and (4) performance of conversational inferences. In addition to these results, it was found that reading activities conducted in classroom must be previously thought by the teacher, through genres choices that are consistent with the objectives of the class and the development of individual activities in which students can think in advance about the text (s) worked, in order to, later, expand their inferences during the interaction moments with the teacher and classmates, aiming to build critical literacies. This study was turned into a didactic proposal that is intended to guide the reading practices conducted by subsequent technical courses teachers.

Keywords: Inferential processes. Text comprehension. Critical Literacies in technical education. Didactic proposal for teaching reading. 
Este estudio investigó los procesos de inferenci en actividades de comprensión de texto en una clase de curso técnico subsecuente en secretariado escolar del Instituto Federal de Brasilia - IFB, campus São Sebastião - DF. Los datos fueron generados por medio de investigaciónacción participativa crítica, en la que la investigadora trabajó como profesora de la clase, gravando audios e imágenes de las actividades realizadas. El suporte teórico del trabajó es guiado por la Sociolingüística Interacional (Goffman ([1964]2002; Gumperz, 1982a e b e Tannen, 2004), ya que se analizó los significados sociales que emergen de las interacciones cara a cara e se investigó las prácticas sociales contextualmente situadas. La Lingüística Textual ofreció embasamiento referente a los conceptos de texto, géneros textuales, referencia e inferencia, fundamentales para las referencias de este estudio sobre la construcción del marco teórico, que dio soporte para análisis de datos. En esta perspectiva, el texto se entiende como actividad sociodiscursiva, en que la referencia y la inferencia constituyen procesos sociodiscursivos (KOCH \& MARCUSCHI, 1998). Por esa razón, los estudios de Vygotsky ([1934]2001 e 1997) sobre pensamiento, lenguaje, aprendizaje e desarrollo, así como los de Tomasello ([1999]2003, 2008 e 2009) acerca de la filogénesis, de la ontogénesis e de la sociogénesis humanas hicieron parte de los fundamentos teóricos de este estudio. También era necesario abordar el letramento en la perspectiva ideológica (BARTON, 1994 e STREET 1984, 1993 e 2014), ya que los colaboradores de esta investigación tuvieron la oportunidad de reflexionar sobre los significados de las prácticas que han experimentado en la clase. La Andragogía (LUDOJOSKI, 1972 e KNOWLES, 1973), área que estudia las prácticas educativas relacionadas al público adulto, también fue utilizada, pues esta disciplina ayuda a los maestros de cursos técnicos subsecuentes a conocer a su público, compuesto mayoritariamente por estudiantes adultos. La metodología utilizada para la construcción del corpus de esta investigación tuvo en la etnografía colaborativa de clase el suporte para el uso de la investigación-acción participativa crítica (KEMMIS \& McTAGGART, 2005) como método utilizado en la investigación educativa que tiene como objetivo transformaciones del contexto de búsqueda. Con el fin de triangular los datos, fue realizado grupo focal (MORGAN, 1977 y BARBOUR, 2009) para investigar el papel de los estudiantes en relación con las actividades realizadas a lo largo de las clases. Los resultados de este estudio indican que los procesos de inferencia se construyeron a lo largo de la realización de actividades integrales de producción textual y en interacciones cara a cara que se produjeron a lo largo de las actividades de lectura colectiva. Cuatro procesos inferenciales fueron revelados: (1) uso de metáforas; (2) uso de narrativas; (3) uso de expresiones referenciales y (4) realización de inferenciales conversacionales. Además de estos resultados, se encontró que las actividades de lectura en clase deben ser pensaba anteriormente por el profesor, a través de la elección de los géneros consistentes con los objetivos de la clase y el desarrollo de las actividades individuales en las cuales los estudiantes pueden reflexionar previamente sobre lo (s) texto (s) trabajado (s) para que, después, se expanden las inferenciales en los momentos de interacción con el profesor y con los compañeros, con el fin de construir letramentos críticos. Este estudio se transforma en propuesta didáctica que se pretende orientar las prácticas de lectura llevadas a cabo por los profesores de los cursos técnicos subsecuentes.

Palabras-llaves: Procesos de inferencias. Comprensión de textos. Letramentos críticos en la enseñanza técnica. Propuesta didáctica para la enseñanza de la lectura. 
INTRODUÇÃO ..........................................................................................................................207

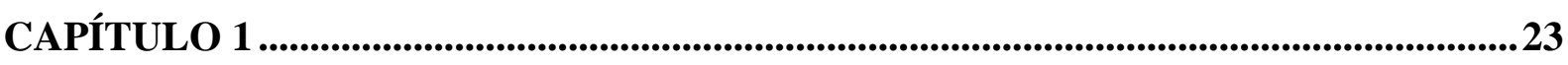

PROCESSOS INFERENCIAIS EM ATIVIDADES DISCURSIVAS.................................23

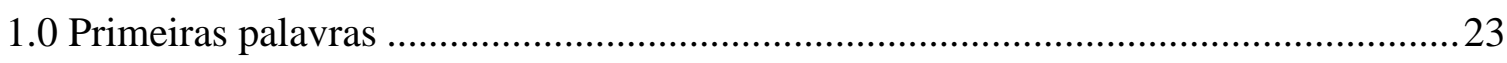

1.1 Ponto de partida: a Sociolinguística Interacional ………….......................................2

1.2 Referenciação como atividade inferencial na construção sociocultural do sentido ....25

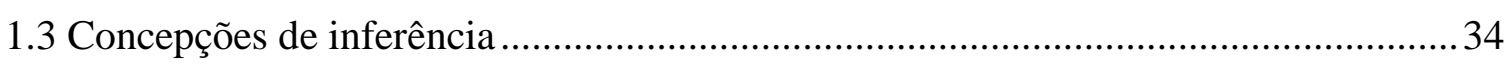

1.4 Pistas de contextualização e construção dos andaimes ................................................. 45

1.5 Processos Inferenciais em Atividades Discursivas .....................................................50

1.5.1. A metáfora no processo inferencial.................................................................50

1.5.2. A narrativa no processo inferencial ................................................................5

1.5.3 O uso de expressões referenciais na construção de inferências ..........................57

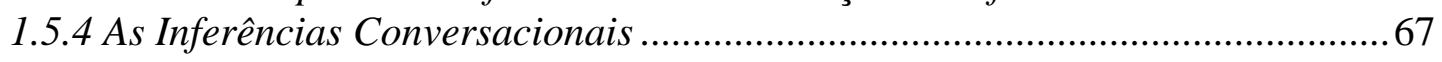

1.6 Reflexões sobre os processos inferenciais............................................................

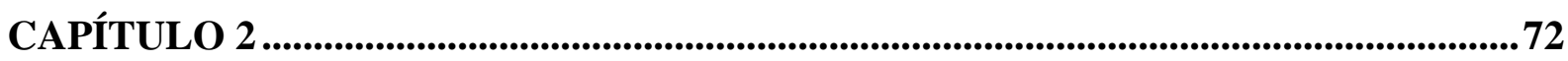

PERSPECTIVAS SOCIOCULTURAIS DA COGNIÇÃO HUMANA................................72

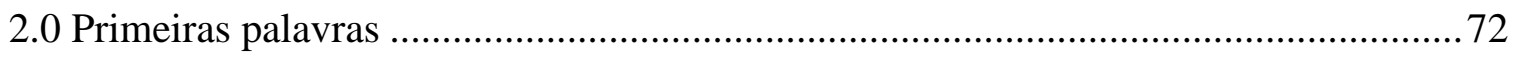

2.1 Vygotsky e a concepção social da mente …………………………………………... 72

2.2 A construção sociocultural do conhecimento ...............................................................79

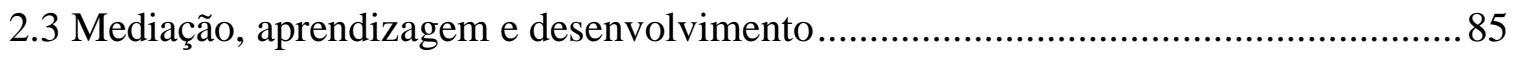

2.4 Cognição humana, linguagem e cultura ...................................................................94

2.5 Reflexões sobre as perspectivas socioculturais da cognição humana ......................... 104

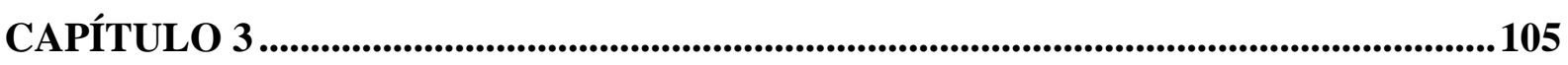

PARA COMPREENDER O PROCESSO DE PESQUISA: O PERCURSO METODOLÓGICO ...............................................................................................105

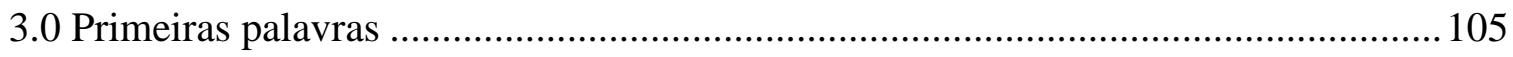

3.1 Da etnografia à etnografia colaborativa de sala de aula ............................................... 105

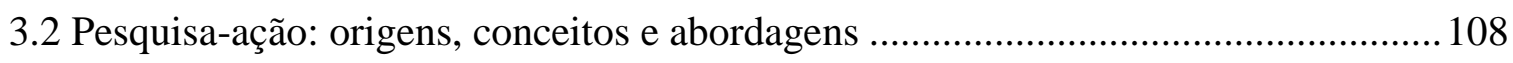

3.3 Convergência da pesquisa participativa com a pesquisa-ação .....................................118

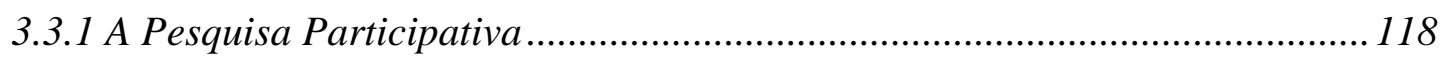


3.3.2 A pesquisa-ação participativa crítica

3.4 Grupo Focal: a voz ativa dos colaboradores de pesquisa

3.5 Relato da geração dos dados: da pesquisa-ação participante crítica ao grupo focal .126

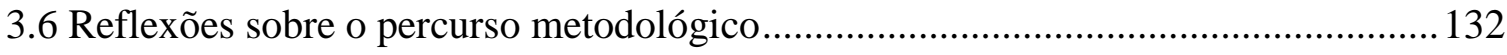

CAPÍTULO 4

O TEXTO COMO PROTAGONISTA DA AULA.

4.0 Primeiras palavras

4.1 Linguística Textual: conceitos e enfoques

4.2 Perspectiva social e discursiva do texto: o estudo dos gêneros

4.3 A multimodalidade no processo inferencial

4.4 O processo de construção dos sentidos dos textos durante atividade escrita

4.4.1 Texto e argumentatividade

4.4.2. A compreensão textual como processo interativo.

4.4.3 Análise das respostas dos alunos

4.5 Reflexões sobre o texto como protagonista da aula ................................................. 169

CAPÍtULLO 5

LETRAMENTOS NO ENSINO TÉCNICO: COMPROMISSO A SER ASSUMIDO .171

5.0 Primeiras Palavras

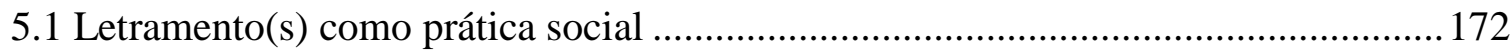

5.2 Letramentos no Ensino Técnico: um olhar para a Andragogia

5.3 Relatos do grupo focal: discurso dos alunos a respeito das atividades vivenciadas .181

5.3.1 O que vocês aprenderam com os 06 encontros?

5.3.2 Como vocês aprenderam o assunto por meio dos textos?

5.3.3. Nas atividades realizadas, quais aspectos mais contribuíram para que vocês compreendessem os textos?

5.3.4. Quais atividades mais colaboraram para que vocês compreendessem o assunto?.

5.4.5. O que vocês acham que os professores podem fazer para aprimorar a compreensão textual da turma?

5.4. Sobre os processos inferenciais revelados: uma proposta didática para atividades de leitura no ensino técnico

5.5 Reflexões sobre os letramentos no ensino técnico: uma proposta didática 
APÊNDICE I............................................................................................................2218

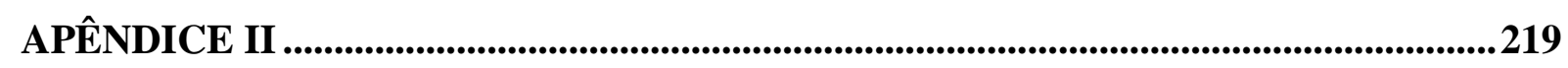

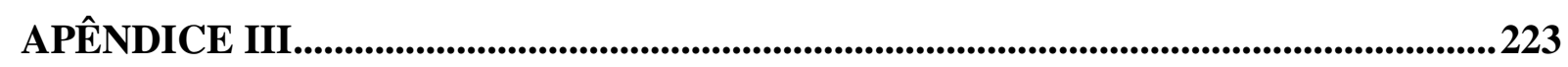

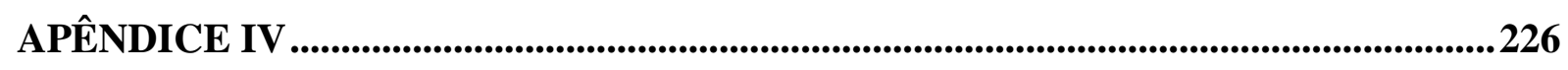

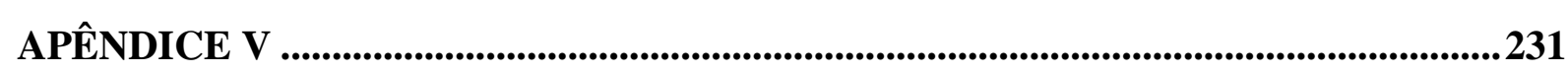

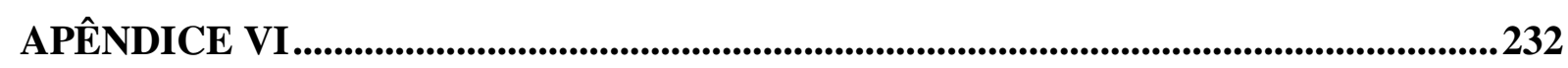

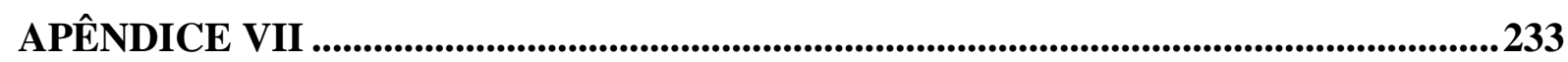




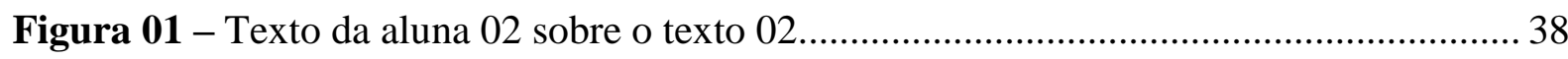

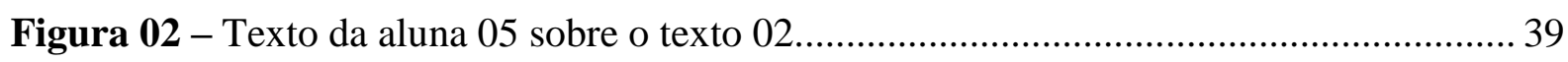

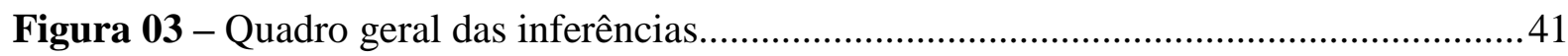

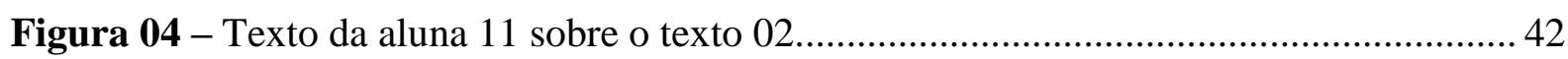

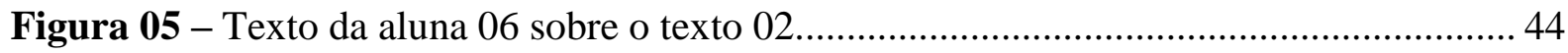

Figura 06 - Excerto 01 do texto da aluna 19 sobre a crise hídrica 02 ...................................52

Figura 07 - Excerto 02 do texto da aluna 19 sobre a crise hídrica 02 ..................................53

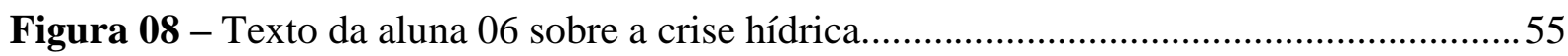

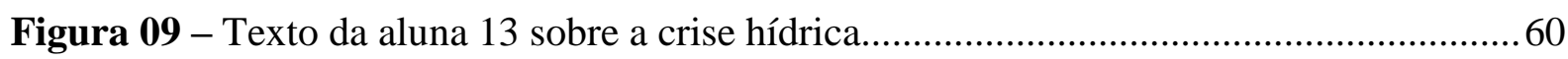

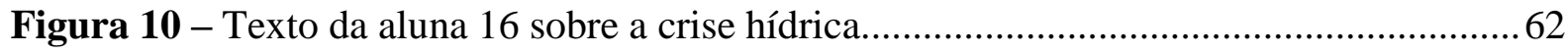

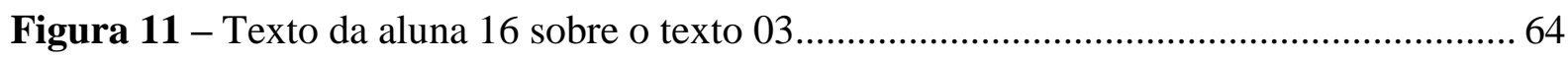

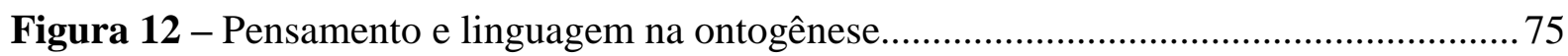

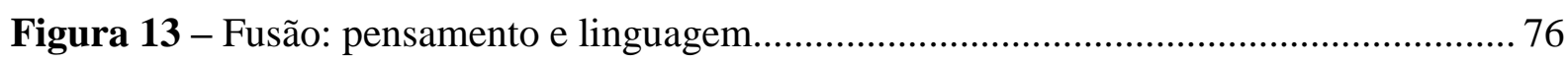

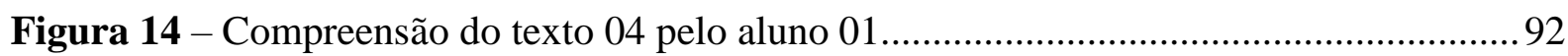

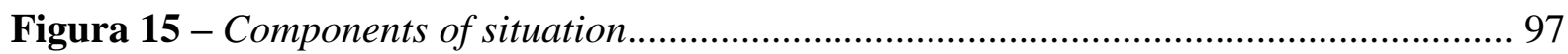

Figura 16 - Compreensão do texto 02 pela aluna 05....................................................... 101

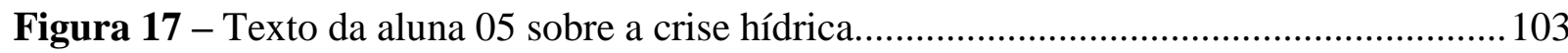

Figura 18 - Passos da pesquisa-ação................................................................................. 115

Figura 19 - Representação do ciclo básico da investigação-ação em quatro fases................. 116

Figura 20 - Espiral da pesquisa-ação........................................................................... 122

Figura 21 - Percurso metodológico da pesquisa-ação participativa crítica............................ 133

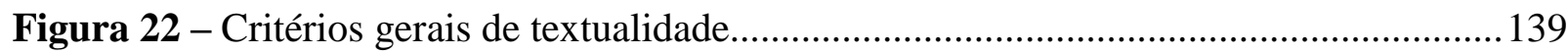

Figura 23 - Infográfico sobre o nível do Sistema Cantareira..............................................153

Figura 24 - Volume útil do reservatório do Sistema Cantareira.............................................. 154

Figura 25 - Contínuo da construção de sentidos................................................................... 161

Figura 26 - Contínuo da construção de sentidos (texto 04) .................................................. 163

Figura 27 - Contínuo da construção de sentidos (texto 03) .................................................. 165

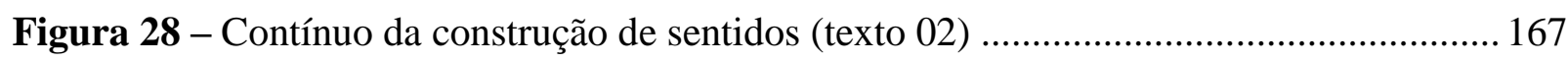

Figura 29 - Contínuo da construção de sentidos (texto 05) ................................................. 168

Figura 30 - Esquema dos processos inferenciais revelados................................................. 191

Figura 31 - Práticas do docente em eventos de letramento no ensino técnico........................ 194

Figura 32 - Proposta didática: encadeamento de ações para o trabalho com a leitura em cursos técnicos. 


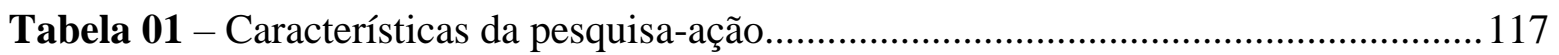

Tabela 02 - Síntese do percurso metodológico.......................................................... 126

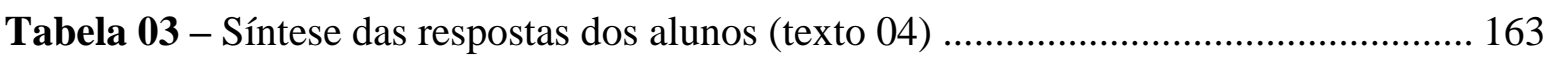

Tabela 04 - Síntese das respostas dos alunos (tex to 03) .................................................. 164

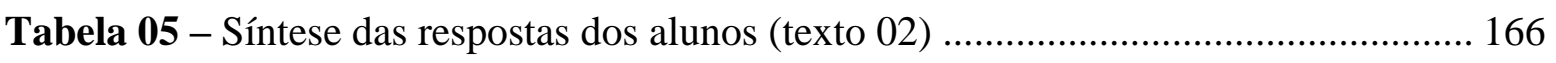

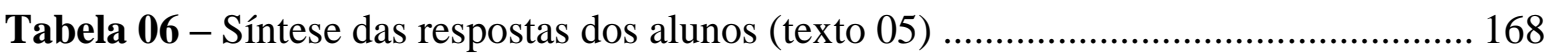




\begin{tabular}{|c|c|c|}
\hline OCORRÊNCIAS & SINAIS & EXEMPLOS \\
\hline $\begin{array}{l}\text { Incompreensão de palavras } \\
\text { ou segmentos }\end{array}$ & ( ) & $\begin{array}{l}\text { Professora, deixa eu te fazer } \\
\text { uma pergunta: o Nordeste, o } \\
\text { Nordeste sempre sofreu com } \\
\text { falta de água ( ) e foi muito } \\
\text { falado não é de agora. }\end{array}$ \\
\hline Hipótese do que se ouviu & (hipótese) & $\begin{array}{l}\text { Que que o povo tem e o } \\
\text { governo não tem? (E aí?). }\end{array}$ \\
\hline Truncamento & l & $\begin{array}{l}\text { /.../ fra/o que está escrito aí e } \\
\text { não olhar a imagem, vai estar } \\
\text { incompleto. }\end{array}$ \\
\hline Sobreposição de falas & {[} & $\begin{array}{l}\text { Professora: /.../ vai estar } \\
\text { incompleto. } \\
\text { [Aluna } \\
\text { 1: }\end{array}$ \\
\hline $\begin{array}{c}\text { Prolongamento de vogal e } \\
\text { consoante }\end{array}$ & $\begin{array}{c}:: \text { podendo aumentar para }:::: \\
\text { ou mais }\end{array}$ & $\begin{array}{l}\text { /.../ o "fundo do poço", é:: } \\
\text { engraçado, né. }\end{array}$ \\
\hline Interrogação & ? & $\begin{array}{l}\text { /.../ E aí, como é que foi? Aí, } \\
\text { depois daquela conversa, } \\
\text { como vocês passaram a } \\
\text { compreender esse texto? }\end{array}$ \\
\hline Pausa & $\ldots$ & $\begin{array}{l}\text { /.../ porque cai bem pouquinho } \\
\text { sabe... o de lá de casa num, } \\
\text { não dá pra encher um balde. }\end{array}$ \\
\hline $\begin{array}{c}\text { Comentários descritivos da } \\
\text { pesquisadora }\end{array}$ & $(())$ & $\begin{array}{l}\text { ((Alunas } 2 \text { e } 3 \text { sinalizam que } \\
\text { concordam)) }\end{array}$ \\
\hline $\begin{array}{c}\text { Citações literais ou leituras } \\
\text { de textos, durante a } \\
\text { gravação }\end{array}$ & " " & $\begin{array}{l}\text { Está escrito "povo" } \\
\text { "governo"... ok. }\end{array}$ \\
\hline $\begin{array}{l}\text { Transcrição parcial ou } \\
\text { eliminação de trecho }\end{array}$ & $\mid \ldots /$ & $\begin{array}{l}\text { A partir da observação da } \\
\text { charge. /.../ Eu gostei bastante } \\
\text { dela. }\end{array}$ \\
\hline
\end{tabular}

\footnotetext{
${ }^{1}$ Fontes: Gumperz (1982a e 1982b) e Marcuschi (2007b). Os exemplos são provenientes do corpus desta pesquisa.
} 


\section{INTRODUÇÃO}

\section{Contextualizar é preciso.}

O interesse pelo tema de pesquisa surgiu desde que a pesquisadora, após o mestrado, passou a atuar em turmas da educação básica, técnica e tecnológica no Instituto Federal de Brasília, doravante, IFB.

O Governo Federal, por meio do Ministério da Educação, promulgou em 2008 a lei ${ }^{\circ}$ 11.892, que instituiu a Rede Federal de Educação Profissional, Científica e Tecnológica, criando os Institutos Federais de Educação, Ciência e Tecnologia.

A Resolução CNE $n^{\circ}$ 06, de 20/09/2012, que define as diretrizes curriculares nacionais para a educação profissional técnica de nível médio, especifica, em seu artigo $8^{\circ}$, inciso II, que, para ingresso em cursos técnicos subsequentes ${ }^{2}$, é exigido que o estudante tenha concluído o ensino médio e que tenha mais de 18 anos. Desse modo, no IFB são recebidos alunos adultos de diversas faixas etárias, havendo predominância, no campus São Sebastião, onde esta pesquisa foi realizada, de alunos que cursaram o ensino médio por meio da EJA Educação de Jovens e Adultos.

A pesquisadora observou, depois do contato com esses estudantes, que a maioria deles possui pouca experiência não apenas em atividades de leitura e compreensão de gêneros textuais relacionados a práticas de letramento vivenciadas em meios escolares, mas também com textos relacionados ao cotidiano desses estudantes no trabalho e na vida privada.

O componente curricular Leitura e Produção de Texto ocupa papel importante nos projetos pedagógicos dos cursos técnicos oferecidos pelo IFB. Nos cursos técnicos subsequentes, a disciplina Leitura e Produção de Texto possui carga horária de 40 a 80 horas/aula ${ }^{3}$, constituindo componente que deve preparar o aluno para as atividades de leitura e produção textual em todo o curso, qualificando-o para o exercício da profissão.

\footnotetext{
${ }^{2} \mathrm{O}$ artigo $7^{\circ}$ da Resolução CNE 06/2012 preceitua que a Educação Profissional Técnica de Nível Médio é desenvolvida nas formas articulada e subsequente ao Ensino Médio. Quando é articulada, os cursos são vinculados ao Ensino Médio e, quando subsequente, é desenvolvida em cursos destinados exclusivamente a estudantes que tenham terminado o Ensino Médio. Toda vez em que houver referência a cursos técnicos neste trabalho, entenda-se por Curso Técnico Subsequente, modalidade na qual a pesquisadora atuou para a geração dos dados que compõem o corpus deste estudo.

${ }^{3}$ A carga horária é definida no Projeto Pedagógico de cada curso técnico subsequente.
} 
Nas aulas de Leitura e Produção de Texto realizadas nesse campus a pesquisadora, por meio da escolha de alguns gêneros textuais, propõe atividades de leitura que levem os alunos a refletirem sobre os aspectos linguístico-discursivos presentes nos textos. Tal cenário faz com que as aulas se tornem espaços para discussões coletivas, nas quais a docente apresenta conceitos, discute temas, lê textos com os alunos e debate os aspectos linguísticos e extralinguísticos neles presentes. Todas essas ações propiciam a construção de contexto dialógico, no qual alguns alunos fazem inferências em voz alta, tiram dúvidas e negociam sentidos com a professora.

Assim, o objetivo geral desta pesquisa é compreender como ocorrem os processos de inferenciação em atividades de compreensão textual, bem como avaliar suas implicações na ampliação das práticas de letramento.

Os objetivos específicos deste trabalho são apresentados a seguir:

i. Investigar como o processamento das expressões referenciais/indexicais contribui para a construção de sentido do texto quando os alunos realizam as inferências.

ii. Revelar como o fornecimento de pistas verbais e não verbais pela professora pesquisadora, durante as discussões, colabora para que os alunos realizem inferências e, consequentemente, a construírem sentido para o texto.

iii. Analisar o grau de conhecimento contextual dos alunos nos processos de referenciação e de categorização/recategorização, tendo em vista o desenvolvimento de estratégia para ampliar esse conhecimento e visando à melhoria do processo de compreensão textual.

iv. Revelar como o trabalho com a diversidade de gêneros textuais multimodais corrobora com a ampliação de conhecimentos linguísticos e extralinguísticos e, consequentemente, com a construção de multiletramentos.

v. Propor atividade didático-pedagógica que possa ser realizada em aulas de quaisquer componentes curriculares a fim de desenvolver habilidades de processamento textual para ampliar as inferências realizadas pelos estudantes.

Esses objetivos específicos estão norteados pelas seguintes questões de pesquisa:

i. Que processos sociocognitivos são realizados pelos alunos durante o processamento textual em atividades escritas e nas interações com a professora-pesquisadora e com os demais colegas? 
ii. Como as pistas verbais e não verbais fornecidas pela professora pesquisadora colaboram para a construção de inferências e atribuição de sentidos ao texto?

iii. De que forma e por quais elementos a compreensão do texto vai sendo atualizada e reconstruída pelos estudantes ao compartilharem suas inferências em momentos de discussão coletiva?

iv. De que modo a apresentação de diversos gêneros textuais multimodais contribui para a ampliação da compreensão leitora dos estudantes e para a construção de multiletramentos?

v. Que atividades didático-pedagógicas podem ser realizadas para desenvolver competência de processamento textual tendo em vista a ampliação das inferências realizadas pelos alunos?

Para a formação profissional no ensino técnico, é necessário o conhecimento de gêneros textuais, além daqueles já vivenciados pelos estudantes, que devem propiciar a eles multiletramentos a fim de que conquistem habilidades para a leitura de textos voltados não apenas para sua prática profissional, mas também para as demais práticas sociais das quais eles possam fazer parte. Por isso, de acordo com a Resolução CNE nº 06, de 20/09/2012, os currículos dos cursos de Educação Profissional Técnica de Nível Médio, devem proporcionar aos estudantes, entre outras habilidades:

I - diálogo com diversos campos do trabalho, da ciência, da tecnologia e da cultura como referências fundamentais de sua formação;

II - elementos para compreender e discutir as relações sociais de produção e de trabalho, bem como as especificidades históricas nas sociedades contemporâneas;

III - recursos para exercer sua profissão com competência, idoneidade intelectual e tecnológica, autonomia e responsabilidade, orientados por princípios éticos, estéticos e políticos, bem como compromissos com a construção de uma sociedade democrática;

IV - domínio intelectual das tecnologias pertinentes ao eixo tecnológico do curso, de modo a permitir progressivo desenvolvimento profissional e capacidade de construir novos conhecimentos e desenvolver novas competências profissionais com autonomia intelectual (...). (Resolução CNE nº 06, de 20/09/2012, Art. 14, Incisos I a IV )

Portanto, pretende-se, com esta pesquisa, apresentar propostas para que professores de cursos técnicos, não apenas os de língua portuguesa, mas aqueles de quaisquer áreas do saber, possam realizar atividades didático-pedagógicas que priorizem o processamento do texto por meio de práticas interativas que permitam aos alunos refletirem sobre as inferências realizadas no momento da leitura, para que eles possam, por meio do diálogo com professores e colegas, 
ampliar a compreensão textual e, consequentemente, conquistar autonomia intelectual nas práticas sociais relacionadas à vida pessoal e profissional.

\section{Os pressupostos teóricos e metodológicos.}

Este trabalho possui embasamento teórico na Sociolinguística Interacional, porque objetiva revelar como os interagentes negociam e partilham significados sociais durante as trocas verbais. Isso requer prática de pesquisa voltada para a interpretação dos significados sociais em determinado contexto.

Desse modo, fez-se a escolha por metodologias qualitativas para a geração dos dados de pesquisa ${ }^{4}$. A pesquisa qualitativa se situa nas experiências vividas, com foco nos significados das ações sociais. Isso significa que esta pesquisa não pretende estudar formas linguísticas idealizadas, mas compromete-se em estudar a língua por meio das ações sociais nas quais ela se insere.

Em relação às teorias que dão suporte ao trabalho, houve preocupação em resenhar os estudos que concebessem língua como prática social contextualmente situada e que estivessem relacionados com o foco dessa investigação. Por isso, teorias da Linguística Textual contribuem sobremaneira para este estudo, de modo especial aquelas relacionadas aos estudos da referenciação e da inferenciação na perspectiva sociodiscursiva.

Para investigar como o processo de compreensão textual se desenrola durante as atividades de leitura, busca-se, nos estudos da sociocognição, esclarecimentos sobre como os estudantes constroem suas inferências. Assim, concebe-se a aprendizagem como processo colaborativo, que conta com recursos não apenas mentalistas para o processamento das inferências, pois a cognição se processa por meio das trocas verbais, e o sentido se constrói na e pela linguagem.

As atividades realizadas com os colaboradores de pesquisa, por meio de pesquisa-ação participativa crítica e grupo focal, serão descritas e analisadas ao longo do trabalho, a fim de evidenciarem-se os procedimentos didáticos que podem ser realizados e que promovem a ampliação da compreensão leitora dos alunos e, portanto, a ampliação dos letramentos construídos no meio escolar.

\footnotetext{
${ }^{4} \mathrm{O}$ termo geração de dados foi adotado pela pesquisadora, pois os pressupostos metodológicos deste trabalho compreendem que os dados são construídos ao longo do processo. Mais informações sobre esse termo serão discutidas no capítulo 03 (p. 105).
} 


\section{Como este trabalho se organiza?}

Com o intuito de discutir as teorias que irão embasar este estudo, articulando-as aos dados gerados, este trabalho será dividido em 05 capítulos, cada qual com seções e subseções necessárias para apresentar os eixos temáticos desenvolvidos. Diferentemente de alguns trabalhos acadêmicos, que apresentam os capítulos teóricos e os de análise de dados separados, este estudo não irá tratar das teorias à parte da análise dos dados gerados. Isso significa que os capítulos 01, 02, 04 e 05 irão discutir as teorias, por meio das resenhas das principais obras que abarcam o tema, assim como analisar os dados gerados por meio de pesquisa-ação participativa crítica. Essa escolha da pesquisadora se justifica pela necessidade de contextualizar a teoria discutida em cada um dos capítulos por meio de exemplos práticos, que foram selecionados do corpus desta pesquisa.

O capítulo 01 apresentará o tema central da tese: o processo inferencial presente nas atividades discursivas. Assim, nele serão discutidos os conceitos relacionados, primeiramente, à Sociolinguística Interacional, ponto de partida deste estudo, seguidos das concepções que envolvem a referenciação como processo interacional, realizado por meio de operações de categorização e recategorização, que tomam forma através da construção dos objetos de discurso (MONDADA \& DUBOIS, 2003). Ou seja, a construção de sentido ocorre de forma interacional e leva em consideração as experiências dos sujeitos (MORATO, 2014). Nesse capítulo, também será feita revisão de literatura incluindo os principais conceitos de inferência, sendo aprofundados aqueles que mais dialogam com a proposta desta pesquisa.

A segunda parte deste trabalho (capítulo 02) tratará de mais um dos pilares que sustentam esta tese: a cognição humana, vista pelo viés da prática social, ou seja, da sociocognição. Os dados apresentados neste capítulo serão analisados à luz das principais concepções que afirmam ser o conhecimento humano resultado de processos socioculturais construídos de modo coletivo e cooperativo (TOMASELLO, [1999] 2003 e 2009), mediado pela relação intrínseca entre pensamento e linguagem. (VYGOTSKY, [1934]2001 e 1991; MORATO, 2002)

O capítulo 03 irá narrar o percurso metodológico empreendido nesta pesquisa. Primeiramente, serão expostas as bases teóricas relacionadas à pesquisa qualitativa com orientação etnográfica, incluindo as pesquisas realizadas em contextos escolares com características colaborativas, que visam à transformação da realidade na qual o professorpesquisador atua. Na sequência, a pesquisadora irá situar este estudo como uma pesquisa-ação 
participativa crítica, na qual atuou diretamente como condutora das atividades, durante o processo de geração dos dados.

No quarto capítulo, a Linguística Textual será retomada e discutida como campo teórico relevante para os estudos linguísticos relacionados ao texto, não somente como estrutura, mas como produto das relações socioculturais e históricas construídas pelos sujeitos (BEAUGRANDE \& DRESSLER, 1981; MARCUSCHI, 2008; VAN DIJK, 2009). Também será feita revisão teórica a respeito das teorias relacionadas aos gêneros textuais. (BAKHTIN, [1979] 1997; MARCUSCHI, 2010; MILLER, 1984; BONINI, 2002 e 2007)

Os estudos da Linguística de Texto voltados para as atividades sociodiscursivas revelarão concepções importantes para o entendimento da inferenciação como atividade interacional. Assim, os textos produzidos pelos alunos, durante o processo de leitura compreensiva, serão analisados, no penúltimo item do capítulo 04, à luz das teorias já discutidas, associadas à Semântica Argumentativa. (VOGT, 1980)

Por fim, o capítulo 05 irá expor os principais conceitos da Andragogia, disciplina que estuda educação e práticas pedagógicas direcionadas ao público adulto (FREIRE, 1967 e 1989; MORALES, 1975; LUDOJOSKI, 1972). Além disso, será discutido o modelo ideológico de letramento (BARTON, 1994 e STREET, 2014) como modo de proposição de eventos de letramento, em turmas de curso técnico, que evidenciem o trabalho com a multiplicidade de gêneros textuais voltados não somente para a prática profissional dos estudantes, mas que compreendam as demais práticas socialmente demandadas.

Em seguida, este capítulo retomará as teorias antes apresentadas a fim de expor, sistematicamente, os processos inferenciais revelados durante a geração dos dados e de apresentar a proposta didática para atividades que envolvam práticas de leitura e compreensão textual em turmas de ensino técnico. 


\section{CAPÍTULO 1}

\section{PROCESSOS INFERENCIAIS EM ATIVIDADES DISCURSIVAS}

As coisas não estão no mundo da maneira como as dizemos aos outros. A maneira como nós dizemos aos outros as coisas é decorrência de nossa atuação intersubjetiva sobre o mundo e da inserção sócio-cognitiva do mundo em que vivemos. O mundo comunicado é sempre fruto de um agir intersubjetivo (não voluntarista) diante da realidade externa e não de uma identificação de realidades discretas.

(Luiz, Antônio Marcuschi)

\subsection{Primeiras palavras}

A referenciação e a inferenciação constituem temas de grande relevância nos estudos linguísticos, especialmente naqueles que entendem língua como prática social. A Semiótica, a Psicologia Cognitiva e a Filosofia da Linguagem também têm colocado esses estudos em lugar privilegiado. Porém, esta pesquisa empenha-se em compreender como ocorre o processo inferencial na produção de textos escritos e orais durante as atividades de compreensão textual e, por essa razão, os estudos voltados para os processos inferenciais serão destacados a fim de investigar, no corpus desta pesquisa, como esses processos contribuem para a efetivação da compreensão textual com vistas à construção do letramento escolar.

Neste primeiro capítulo, a inferenciação será abordada, principalmente, dentro da perspectiva da Sociolinguística Interacional, da Linguística Textual e da Pragmática, por constituírem áreas nas quais este trabalho se fundamenta. E também por conceberem os processos inferenciais como atividades discursivas construídas no processo interacional e processadas por meio de atividades sociocognitivas.

Desse modo, os estudos da Sociolinguística Interacional corroboram para a compreensão de como os processos inferenciais também se realizam dentro das trocas verbais que acontecem no curso da interação entre professora-pesquisadora/alunos e alunos/alunos. As análises a serem realizadas, ao longo desse capítulo, são embasadas nas concepções de inferência conversacional, bem como nas pistas de contextualização (GUMPERZ, 1982a), o que situa esta pesquisa não somente na análise dos textos escritos dos alunos, mas na relação entre o individual e o social, que constitui linha muito tênue quando se entende língua como ação social. 
A Linguística Textual, na concepção contemporânea, compreende o texto como evento histórico-social, estabelecendo para ele uma agenda de estudos baseada nas questões sociocognitivas que envolvem a referenciação, a inferenciação, o acesso ao conhecimento prévio, (...) o tratamento da oralidade e da relação oralidadelescrita; e o estudo dos gêneros textuais. (KOCH, 2001, p. 14).

A Pragmática focaliza os estudos acerca da concepção cultural dos sentidos partilhados pelos interagentes, pois inclui em suas análises as intenções do falante, o contexto, os usuários e a linguagem em uso (LEVINSON, 2007, p. 06). Nesse sentido, a Pragmática auxilia estudos que procurem revelar como os sentidos são constituídos por meio da negociação entre os interagentes quando inseridos em determinado contexto de interação.

Enfim, as concepções a serem apresentadas e discutidas neste primeiro capítulo pretendem situar este trabalho como uma investigação qualitativa, socialmente situada, que procura revelar quais os processos inferenciais presentes nas atividades de compreensão textual realizadas pelos estudantes que colaboraram com esta pesquisa, a fim de contribuir para que professores de diversas áreas do conhecimento compreendam esses processos e possam utilizar metodologias que os levem em consideração.

\subsection{Ponto de partida: a Sociolinguística Interacional}

Gumperz (1982a) apresenta a contribuição dos estudos da Sociolinguística Interacional para compreender os processos sociais que envolvem as práticas interacionais. Esse autor (1982a, p. 21) aponta para a concordância entre psicólogos, linguistas e sociolinguistas de que existem processos que envolvem o processamento simultâneo de informações em vários níveis de generalidade. Portanto, para se determinar aquilo que se entende em qualquer contexto conversacional, Gumperz, sugere que existem esquemas ou frames interpretativos (TANNEN \& WALLAT, 1987) que permitem aos interagentes distinguirem entre as opções de interpretação admissíveis.

Por essa razão, a investigação proposta neste trabalho se apropria da Sociolinguística Interacional, pois essa disciplina busca estudar os modos como os interagentes negociam e partilham significados sociais durante as trocas verbais. Assim, as análises das interações verbais realizadas durante as aulas gravadas constituem material de análise de primordial importância da mesma forma que a análise dos textos escritos produzidos pelos estudantes. 
Conforme Tannen (2004, p. 76) a Sociolinguística Interacional é um tipo de análise qualitativa que se situa na interseção entre Linguística, Antropologia e Sociologia. Ancorada na abordagem teórica e metodológica de Goffman ([1964] 2002) e Gumperz (1982a), essa área de estudos realiza análise das relações sociais estabelecidas por meio da linguagem verbal e não verbal. Com a publicação de Discourse Strategies, em 1982, Gumperz apresentou o campo teórico e metodológico da Sociolinguística Interacional e situou essa disciplina no campo da análise linguística voltada para as práticas sociais estabelecidas entre os sujeitos, durante as interações, por meio das diversas atividades de fala ${ }^{6}$.

A noção de contexto é, portanto, essencial para a Sociolinguística Interacional, pois o estudo dos significados sociais presentes nas interações deve compreender a atualização constante do contexto, que não pode ser visto como algo distante do discurso. Nessa concepção, os interagentes criam o contexto por meio das pistas linguísticas verbais e não verbais (TANNEN, 2004, p. 77). Dentro dessa perspectiva, os sentidos não são criados por um interagente sozinho, mas construído coletivamente por meio das atividades de fala realizadas durante a aula.

Portanto, a investigação do processo inferencial em atividades de compreensão de textos parte do pressuposto de que os sentidos ${ }^{7}$ são construídos por meio de um conjunto de interpretações situadas e compartilhadas socialmente (GUMPERZ, 1999). As inferências conversacionais são construídas dentro de um processo contínuo dentro do qual a interpretação dos sentidos não está ligada às palavras ditas, mas a todos os aspectos que envolvem o como elas são ditas. (TANNEN, 2004, p. 77)

\subsection{Referenciação como atividade inferencial na construção sociocultural do sentido}

O discurso científico, principalmente o das ciências naturais e o das abordagens linguísticas mais estruturalistas e formalistas, pressupõe o poder referencial da linguagem

\footnotetext{
${ }^{5}$ Tradução própria.

${ }^{6}$ As atividades de fala são geradas, nos termos de Gumperz (1982a, p. 166), por um conjunto de relações sociais que possuem fins comunicativos específicos. Assim, o contexto de sala de aula no qual esta pesquisa se insere, possui atividades de fala relacionadas às práticas interacionais construídas durante a interação entre professorapesquisadora/alunos e alunos/alunos.

${ }^{7}$ No texto original de Gumperz (1999, p. 454), esse autor utiliza a palavra meaning, que, na tradução para a língua portuguesa, pode se referir a "significado" ou a "sentido". A não distinção dessas duas acepções pode acarretar problemas teóricos relevantes, pois a primeira acepção se aproxima de uma concepção mais formal de língua, na qual o significado das coisas constitui uma referência direta do mundo. Desse modo, convém destacar que, neste trabalho, a acepção para meaning será a de "sentido", pois condiz com o que se defende neste estudo: o caráter processual, interacional e social da compreensão textual, como será mais pormenorizado no desenrolar deste capítulo.
} 
legitimado por relação direta e verdadeira entre as palavras e as coisas. Assim, nessa concepção, a palavra sempre irá se relacionar a uma coisa específica, constituindo uma estabilidade da língua e das entidades a que ela se refere. No entanto, propõe-se considerar, na verdade, a instabilidade das coisas do mundo representadas pela linguagem e pelo pensamento, para, depois do estudo sobre como essas instabilidades funcionam num determinado contexto, apresentar as possíveis estabilidades, considerando as categorias linguísticas e cognitivas presentes nesse processo. (MONDADA \& DUBOIS, 2003, p. 19)

Seguindo essa linha, Mondada \& Dubois (ibid, p. 29) propõem o estudo da referenciação que leve em consideração as práticas simbólicas, ou seja, a parte não linguística em que o texto é produzido e interpretado. Essas práticas sugerem a construção de objetos cognitivos e discursivos na intersubjetividade das negociações, das modificações, das ratificações de concepções individuais e públicas de mundo. (Ibid, p. 20)

As autoras sugerem, assim, a utilização do termo referenciação, em vez de referência, pois defendem visão dinâmica que considera não somente o sujeito encarnado, mas o sujeito de relações, sociocognitivo, que trafega não em si mesmo, mas numa rede de relações complexas mediadas pelos discursos e pelo mundo.

Mondada \& Dubois (2003), de tal modo, organizam o conceito de referenciação sob a defesa dos seguintes tópicos, que serão aprofundados adiante:

(1) a referenciação possui instabilidade em relação às coisas/ao mundo, assim como a representação disso por meio da linguagem/palavras;

(2) a referenciação possui caráter dinâmico e sociocognitivo;

(3) a instabilidade linguística ocorre dentro das práticas linguísticas e cognitivas;

(4) a construção de referentes ocorre de modo colaborativo, sendo negociado pelos sujeitos;

(5) a construção da referenciação passa por processos de estabilização em níveis psicológicos e também linguísticos.

O primeiro tópico diz respeito à instabilidade, que é inerente aos objetos do discurso e às práticas sociais (Ibid, p. 22), fazendo das categorizações sociais variáveis, instáveis e flexíveis. Elas mudam conforme as relações sociais e vão se transformando em razão do contexto. Mondada \& Dubois (ibid, pp. 22-23) nomeiam de variações sincrônicas e diacrônicas dos usos das categorias comuns as mudanças que tornam as categorizações sociais instáveis.

A categorização e a recategorização fazem parte da atividade de referenciação e são realizadas por meio da compreensão das expressões referenciais. Sendo assim, entende-se por 
categorização o processo pelo qual se agrupam entidades semelhantes, mas não necessariamente idênticas (objetos, pessoas, lugares etc.) em classes específicas (FERRARI, 2011). Ela ocorre não somente pela denominação lexical, sendo recurso muito importante para apreensão de sentido no texto. Desse modo, entende-se que a categorização está relacionada ao contexto no qual o enunciado é produzido envolvendo o discurso que precede o texto, o contexto linguístico, o gênero textual, o estilo/registro (se formal ou informal) e o campo discursivo (legal, eclesiástico, didático, político etc.). (CLARK, 1996; FERRARI, 2011)

Nesse sentido, a categorização depende de valores sociais estabelecidos por determinada cultura e é realizada pelos atores sociais, os quais selecionam ou excluem certa categorização para determinada coisa ou pessoa. Essas são questões muito mais voltadas à Pragmática do que à Semântica dos objetos, visto que afetam muito mais os objetos sociais do que os objetos psíquicos, fazendo com que a organização do conhecimento humano seja motivada pelos fins adaptativos. (MONDADA \& DUBOIS, 2003, p. 23). Isso indica que os sistemas cognitivos das pessoas são adaptados para serem flexíveis. Por exemplo, a palavra chuveiro pode ter acepções diferentes, como no diálogo entre a professora-pesquisadora e os alunos, na aula $04^{8}$.

\section{Excerto 01 - Aula 049}

01 Professora ${ }^{10}:$ /.../se nós pensarmos, se a gente colocar num balde, né, a água caindo do chuveiro 02 durante cinco minutos é muita coisa, o cálculo de água que daria, eu não tenho essa noção, mas é 03 muito... parar para pensar, é muito.

04 Aluna 01 ${ }^{11}$ : Professora, depende do chuveiro.

05 Professora: Depende do chuveiro também.

06 Aluna 01: Vai depender do chuveiro também, se for ducha.

\footnotetext{
${ }^{8} \mathrm{O}$ excerto 01 refere-se a uma discussão realizada na aula 04 acerca do boletim informativo da rádio Nova Brasil FM, que conscientiza os ouvintes a economizarem água nas tarefas domésticas, inclusive no banho.

${ }^{9}$ Os dados gerados nesta pesquisa serão apresentados do seguinte modo: os excertos provenientes da transcrição das 06 aulas gravadas ou do grupo focal serão enumerados em ordem crescente (aula 01, aula 02... grupo focal; excerto 01 , excerto $02 \ldots$ ). Os textos também serão enumerados na ordem crescente e terão sempre a mesma numeração que foi dada a eles na primeira vez em que apareceram.

10 Toda referência que houver ao turno conversacional da professora, entenda-se que se trata da professorapesquisadora, autora deste trabalho.

${ }^{11}$ Os alunos foram enumerados pelas interações que ocorreram em cada aula. Isso significa que a aluna 03, da aula 01, não é a mesma aluna 03, na aula 03, por exemplo. Não foi possível atribuir nomes fictícios a esses colaboradores, pois a câmera que gravou as imagens permanecia na mesma posição durante toda a aula. Assim, alguns alunos que se encontravam no meio e no final da sala não apareceram no vídeo e não puderam ser identificados durante a transcrição e a análise de dados. Só foi possível, então, transcrever suas falas e, para evitar imprecisão, optou-se pela referência aos colaboradores de pesquisa por numerais arábicos. Há alguns casos, nos quais foi possível identificar o mesmo aluno em diversos contextos (interação em sala de aula, grupo focal e/ou produção textual). Neles, o número do aluno será o mesmo e as participações do estudante serão relacionadas umas às outras.
} 
07 Professora: Numa ducha cai muita água, já tem aquele chuveiro que cai bem pouquinho.

08 Aluna 01: De lá da minha casa mesmo, não enche um balde, entendeu, porque cai bem

09 pouquinho sabe... o de lá de casa num, não dá pra encher um balde.

Como se pôde observar, no Excerto 01, a palavra chuveiro, primeiramente, foi tratada pela professora em termos gerais, assim como exposto neste fragmento do boletim informativo:

\section{Texto $01^{12}$ - Trecho do Boletim Informativo 01 - Rádio Nova Brasil FM}

“...O banho deve ser rápido. Cinco minutos são suficientes para higienizar o corpo. A economia é ainda maior se você fechar o registro na hora de passar sabonete. A água que cai do chuveiro também deve ser reaproveitada para outras atividades da casa, como a lavagem do quintal..."

As palavras destacadas banho, registro e, posteriormente, chuveiro pertencem ao mesmo campo semântico que remete ao ambiente de banho, cujo sentido construído pela professora foi de chuveiro - objeto responsável pela queda de água que faz parte do banho a que a cultura brasileira está adaptada. A professora utilizou essa palavra em termos gerais, como se todo chuveiro tivesse o mesmo volume de queda d'água, a ponto de cinco minutos serem suficientes para encher vários baldes de água. Todavia, a aluna 01 afirmou que, no chuveiro da casa onde reside, esse feito não seria possível, pois a água escoava com dificuldade, não havendo uma boa saída do fluxo de água.

A referência (imagem mental) da professora era a de um chuveiro com características de ducha, que seria capaz de encher uma grande quantidade de baldes de água, mas a aluna 01 tinha a representação do chuveiro da sua casa, do qual saía pouca água, não podendo, nesse contexto, encher muitos baldes. Esse excerto exemplifica a instabilidade na categorização do chuveiro, e indica a plasticidade linguística e cognitiva por meio da adequação contextual e adaptativa (MONDADA \& DUBOIS, 2003, p. 25). Portanto, a instabilidade caracteriza o modo normal e rotineiro de entender, descrever, compreender o mundo - e lançar assim a desconfiança sobre toda descrição única, universal e atemporal do mundo. (Ibid, 2003, p. 28)

Compreender, nesse contexto de análise, o conceito de plasticidade cerebral (ou plasticidade cognitiva) irá ajudar na compreensão do modo como os alunos processam o conteúdo textual. O termo plasticidade tem origem nas neurociências, com William James (1980), na obra The Principles of Psychology, na qual esse termo foi introduzido como modo

\footnotetext{
${ }^{12}$ A rádio Nova Brasil FM gentilmente concedeu, via e-mail, o áudio dos boletins informativos após solicitação da pesquisadora.
} 
de demonstrar a susceptibilidade dos seres humanos para a modificação das estruturas cognitivas.

As pesquisas, até meados do século XIX, indicavam que o cérebro humano não possuía capacidade de divisão neuronal, e isso tornava as lesões cerebrais irreversíveis, não havendo possibilidade de adaptação para pessoas com alguma deficiência e nem de recuperação para aquelas que tiveram essas regiões cerebrais atingidas em razão de acidentes e doenças. Conforme James (1980, p. 105), plasticidade refere-se

\begin{abstract}
ao sentido amplo de designar estruturas fracas o bastante para ceder, mas fortes o suficiente para não ceder tudo de uma vez. Cada fase de equilíbrio em tais estruturas é marcada por poder evocar novos conjuntos de hábitos. A matéria orgânica, especialmente o tecido nervoso, parece provido de um grau extraordinário de plasticidade; de modo que nós podemos, sem hesitação, estabelecer como nossa primeira proposta o seguinte: que os fenômenos dos hábitos dos seres vivos devemse à plasticidade dos materiais orgânicos dos quais seus corpos são compostos ${ }^{13}$. (Ibid, p. 105)
\end{abstract}

Morato (2014, p. 306) defende que a plasticidade cognitiva é construída por fatores socioculturais:

\begin{abstract}
Mais e mais estudos realizados nas últimas décadas, interessados em aspectos não estrita ou meramente paralelistas ou localizacionistas da relação entre processos linguísticos e cerebrais, têm admitido, face à evidência empírica de uma plasticidade cerebral altamente associada a fatores tidos como "externos" (experiência cultural, aprendizagens formais e informais, condições materiais e simbólicas da vida em sociedade, aspectos psicoafetivos, etc.), que dificilmente é possível sustentar a tese de uma estrita lateralização ou dominância hemisférica. (Ibid, p. 306)
\end{abstract}

As descobertas acerca da plasticidade cognitiva apontam para a dinamicidade da cognição humana, ao refutarem a tese de que existe um período específico para aprendizagem. A capacidade cognitiva dos seres humanos, nesse sentido, é adaptativa ao contexto sociocultural do qual fazem parte e é modificada e ampliada, a todo instante, nas interações que eles estabelecem ao longo da vida.

A noção de plasticidade cognitiva confere caráter dinâmico e sociocognitivo à referenciação, por ocorrer em práticas linguísticas nas quais a instabilidade da construção dos sentidos se manifesta. Logo, a elaboração de termos não parte mais de uma espécie de cartografia de palavras-etiqueta que nomeiam as coisas reais do mundo, mas

em termos de identificação de um dispositivo geral que explore as restrições e as potencialidades linguísticas para desenhar uma representação cognitiva socialmente compartilhada da realidade. Os locutores marcam, eles mesmos, os deslizes entre

13 Tradução própria. 
referencialidade e negociação intersubjetiva dos processos de referenciação, pelos comentários metalinguísticos que pontuam seu discurso. (MONDADA \& DUBOIS, 2003, p. 32)

Por isso, a categorização das coisas do mundo não é fornecida por processos somente cognitivos, mas varia de acordo com as atividades sociocognitivas que o sujeito exerce, incluindo os artefatos culturais construídos e a capacidade de recategorizar o mundo por meio do processo de interação e de negociação com outrem, produzindo, por meio disso, categorias potencialmente memorizadas e lexicalizadas. (Ibid, 2003, p. 35)

A construção dos referentes (objetos de discurso) ocorre, consoante essas autoras (ibid, p. 35), de modo colaborativo e é negociada entre os sujeitos, ou seja, sua existência é estabelecida por meio do discurso, emergindo de práticas simbólicas e intersubjetivas. Por essa razão, a concepção de referenciação não se restringe a um processo objetivo e verificável, no qual são definidos conceitos e designações para termos e palavras. Ao contrário disso, a atividade referencial é construída intersubjetivamente por meio das práticas interacionais de negociação de sentidos.

Cavalcante \& Santos (2012, p. 660) afirmam que

\begin{abstract}
penetrar o sentido de um texto implica, necessariamente, engendrar diversos processos referenciais. A construção da referência é um processo dinâmico; dependendo das relações intertextuais e interdiscursivas, por vezes, ela se move sobre ambiguidades contextuais, exacerbando ainda mais esse dinamismo, que exige do leitor maior elasticidade nas expectativas que cria.
\end{abstract}

Os sentidos são construídos, então, na relação dinâmica entre língua e práticas sociais, da qual se originam os objetos-de-discurso por meio dos quais os interagentes percebem a realidade.

Para Tomasello ([1999] 2003, p. 135), a referenciação é um ato social no qual uma pessoa chama atenção de outra para voltar o olhar para algum ponto em comum no mundo. Portanto, ela deve ser entendida dentro do contexto das interações sociais, que esse autor nomeia de cenas de atenção conjunta ${ }^{14}$. As cenas de atenção conjunta fornecem o contexto intersubjetivo, no qual ocorre o processo de simbolização. A cena referencial simbolizada na linguagem concerne, pois, apenas um subconjunto de coisas que ocorrem nas interações intencionais da cena de atenção conjunta. (TOMASELLO, [1999] 2003, p. 138)

\footnotetext{
${ }^{14}$ As cenas de atenção conjunta se referem às atividades interativas estabelecidas nos vários eventos sociais. Neste trabalho, o evento social aula representa uma cena de atenção conjunta. Esse conceito será pormenorizado no capítulo 02 .
} 
A discussão apresentada pode ser visualizada no Excerto 02, em que a professorapesquisadora introduz o tema que guiará a produção escrita da turma no decorrer da quarta aula. O texto que embasa essa produção foi retirado da revista Super Interessante (Anexo II), publicado no site da revista (http://super.abril.com.br/crise-agua/ofundodopoco.shtml) e se chama Fundo do Poço. Durante a conversa prévia que a professora estabeleceu com os alunos, antes de eles começarem a escrever os textos, ela os questiona sobre o que significa o termo "fundo do poço".

\section{Excerto 02 - Aula 04}

01 Professora: /.../ é um texto que fala da crise hídrica tá é::: é um texto muito interessante tá ele,

02 ele é um texto que traz diversas informações, então vamos perceber que dentro desse texto nós

03 temos diversas possibilidades de leitura, a primeira possibilidade de leitura está na manchete, o

04 que diz a manchete? Bem grande.

05 Alunos: "O fundo do poço".

06 Professora: "O fundo do poço", é:: engraçado né, é::: a gente não vai comentar agora o que quer

07 dizer fundo do poço, mas eu quero que vocês já façam essa reflexão é, quando eu digo que

08 alguém está no fundo do poço, mas que poço lembra o quê?

09 Alunos: A água.

10 Professora: A água. E tem o que aqui né? Então é muito sugestiva essa manchete da reportagem.

11 Aluno 03: Então, tá certo. Professora, só comenta mais um pouco sobre a frase "o fundo do poço".

12 Professora: "Fundo do poço", tenta, tenta fazer uma correlação entre estar no fundo do poço,

13 quando eu digo assim, é "aquele meu amigo está no fundo do poço", eu quero dizer o quê? Né, e

14 aí tenta relacionar, que tem dois significados aí nessa, nessa, nesse título da reportagem, tem um

15 significado de estar no fundo do poço que é esse que eu acabei de falar, quando eu digo que uma

16 pessoa está no fundo do poço, eu estou querendo dizer o quê? E tem uma outra /.../ tem uma outra

17 inferência que nós podemos fazer de fundo do poço que é..., Hã... em relação à água né, poço, o

18 poço no sentido real da palavra, é o poço artesiano que tem água no fundo /.../ I.../

19 Aluna 02: ( ) Na pior né, só ele e as necessidades dele.

20 Professora: Façam essa reflexão, eu não posso falar muita coisa até então, só posso dar essas

21 pistas pra vocês. I.../

22 Professora: /.../ Sim, exatamente, aí você pode relacionar o poço artesiano com esses 23 reservatórios.

24 Aluno 03: Porque tem uma parte de recurso hídrico que é a falta d'água, aí ele coloca "fundo do 25 poço", aí a gente não vai associar o poço ao poço artesiano.

26 Professora: Mas é o que ele representa /.../.

27 Aluno 03: Mas ele representa a, como é que se diz, fugiu aqui, eu tava na cabeça.

28 Professora: Ele representa a produção de água de São Paulo.

29 Aluno 03: O reservatório. O reservatório seria um ápice, seria um poço né?

30 Professora: Exato. Exato, é isso.

31 Aluno 03: Porque se a gente for observar bem não encaixa um poço artesiano aqui.

32 Professora: No sentido estrito da palavra, não, mas aí você relaciona o poço com o reservatório

33 de água, com a realidade de São Paulo. 
Por mais que a professora não quisesse fornecer muitas informações a respeito do texto, pois pretendia que, nesta primeira etapa da atividade, os alunos construíssem os sentidos de maneira mais individual por meio da escrita, o aluno 03 sentiu necessidade de estabelecer relações categoriais a respeito da expressão no fundo do poço (linhas 11, 24 e 25). Naquele momento, ele não estava se sentido à vontade para construir um texto, pois não conseguiu criar relações discursivas entre a palavra poço e o tema do texto, que era a crise hídrica no Estado de São Paulo. Assim, o diálogo colaborativo entre o aluno 03 e a professora-pesquisadora auxiliou os demais estudantes a compreenderem o motivo pelo qual os autores do texto elegeram esse termo como título da reportagem.

Inicialmente, a professora-pesquisadora convidou os alunos a refletirem acerca do significado da expressão fundo do poço - levando-os a pensar nessa expressão no contexto relacionado a uma pessoa: /.../mas eu quero que vocês já façam essa reflexão é, quando eu digo que alguém está no fundo do poço (linhas 07 e 08). Porém, a aluna 02 responde que poço lembra água - o que faz sentido também, todavia, não era o que a professora esperava ouvir naquele momento, haja vista que a expressão fundo do poço indicaria que alguém estava mal. Por isso, entre as linhas 12 e 18, a docente tentou fornecer pistas para que os estudantes compreendessem o duplo sentido da palavra poço, no texto em questão, como a situação precária na qual se encontrava o Estado de São Paulo em razão da redução dos níveis de água nos principais reservatórios desse Estado.

Morato (2008, p. 171) afirma que os sujeitos envolvidos na interação são obrigados a "trabalharem" sociocognitivamente sobre o significado (aspas da autora) ou por meio de algum insight ou sistema conceitual de natureza essencialmente mental e psicológica. Os sistemas conceituais são construídos por meio da interação dos sujeitos com o meio social e histórico no qual estão imersos. Por isso, os processos cognitivos são, antes de tudo, moldados pelas condições sociais. A linguagem, por conseguinte, é sistema simbólico que se materializa nas relações sociais e é responsável pela construção subjetiva do significado.

A indicialidade da linguagem torna-se clara nesse momento da quarta aula e indica a necessidade de compreender o discurso em seu contexto de produção. Isso indica que a categorização é adaptativa, pois as descrições de mundo são necessariamente incompletas, e a categorização evolui de modo flexível fazendo com que a produção seja indissociável do trabalho de interpretação (MONDADA \& DUBOIS, 2003, p. 40). Desse modo, os interagentes completam essas descrições e as ajustam ao contexto. 
Todo o diálogo descrito no Excerto 02 indica o caminho percorrido entre a instabilidade dos níveis psicológico e linguístico de construção da referenciação com vistas à estabilização desses. Mondada \& Dubois (2003, pp. 41-42) recorrem à concepção de protótipos e estereótipos (ROSCH, 1978, p. 49) como contínuos que contribuirão para a estabilização linguística.

Os protótipos correspondem aos rótulos sociais atribuídos aos nomes. Então, poço, teve, inicialmente, para aluna 02, o sentido de fonte e reservatório de água. Entretanto, através da mediação da professora-pesquisadora, o diálogo foi evoluindo para a junção de protótipos das palavras fundo e poço ligados pela preposição de $+o$. A discussão durante esse período caminhou para estabelecer um estereótipo, ou seja, após a apresentação de todos os protótipos possíveis, chegou-se à estabilização da expressão linguística fundo do poço.

Todavia, como será analisado mais adiante, o processo de estabilização não é o mesmo para todos os alunos, o que se torna claro por meio da análise dos textos escritos produzidos por eles, cujos conteúdos indicaram vários processos de categorização e, na maioria das vezes, a estabilidade dos níveis psicológicos e linguísticos ocorreu mediante interação verbal com os colegas e com a professora-pesquisadora. Em conclusão, Mondada \& Dubois (2003, p. 43) ratificam que a evolução dos protótipos e das significações das palavras para estereótipos não se baseia mais em propriedades realistas ou de valores de verdade, mas na codificação social dos modos de falar e de representar o mundo (...).

Por essa razão, Marcuschi (2000, p. 38) compreende que a referenciação é muito menos uma determinação linguística e muito mais uma ação conjunta num processo interativo com atividades inferenciais realizadas na enunciação, sem esquecer que a cognição situada exerce um papel central. Nesse sentido, precisa-se muito mais do que compreender como funciona o processo de construção de sentido durante a interação, é necessário verificar quais sentidos são possíveis de serem construídos durante a interação obtendo-se, assim, análise sociocognitiva da construção de sentidos por meio da interação com textos.

Portanto, a referenciação constitui ação cognitiva, discursiva, pragmática e sociointeracional, pois entende a linguagem como atividade colaborativa, na qual os sujeitos interagem e se autoajudam com o objetivo de acertar as arestas da significação, produzindo criativa e coletivamente os sentidos para as expressões que circundam as práticas linguísticas. A interação deve ser entendida não como a fonte dos sentidos (MARCUSCHI, 2000, p. 43), mas como o ponto de convergências para a construção de referentes. 
Cultura, sociedade e cognição estão na base de toda capacidade humana de pensar e de dizer o mundo. Por isso, a referenciação ocorre não somente como um processo cognitivo desconectado de questões sociais, mas constitui a soma da cognição com as questões sóciohistóricas, reveladas em atividades de categorização de esforço coletivo, e não individual. (MARCUSCHI, 2007a, p. 83)

A referenciação é, portanto, atividade discursiva (KOCH \& MARCUSCHI, 1998; MARCUSCHI, 2000, 2008; KOCH, 2005) e, por isso, contextualizada. Os referentes passam a ser concebidos como objetos de discurso elaborados pelos interlocutores. Por isso, as categorias são definidas e estabilizadas nas práticas discursivas (LIMA E FELTES, 2013, p. 32). Acerca disso, Koch entende que

\footnotetext{
a língua não existe, portanto, fora dos sujeitos sociais que a falam e fora dos eventos discursivos nos quais eles intervêm e nos quais mobilizam suas percepções, seus saberes quer de ordem linguística, quer de ordem sócio-cognitiva [sic], ou seja, seus modelos de mundo. Estes, todavia, não são estáticos, (re)constroem-se tanto sincrônica como diacronicamente, dentro das diversas cenas enunciativas, de modo que, no momento em que se passa da língua ao discurso, torna-se necessário mobilizar conhecimentos - socialmente compartilhados e discursivamente (re)construídos - , bem como situar-se dentro das contingências históricas, para que se possa proceder aos encadeamentos discursivos. (KOCH, 2008, p.101)
}

Em outros termos, entende-se que os objetos do discurso são dinâmicos. Quando introduzidos, são compartilhados, transformados, ativados, reativados e categorizados pelas práticas sociais. Quando a língua se materializa por meio do discurso, os sentidos passam também a ser descobertos, categorizados e recategorizados pela atividade social. Portanto, a referenciação é um processo e, ao longo dele, os objetos do discurso são construídos e reconstruídos de modo instável, ancorados na sociocognição.

\subsection{Concepções de inferência}

A primeira questão a ser pensada, antes de voltar o olhar para o conceito de inferência, é a elucidação das diferenças entre inferência e implicatura, pois ambas possuem significações muito próximas que podem gerar conflitos de natureza teórica. As implicaturas estão ligadas ao ato de insinuar, sugerir ou transmitir algum significado indiretamente por meio da linguagem. Já as inferências relacionam-se com o processo de dedução que os sujeitos fazem a partir de evidências linguísticas, paralinguísticas ou não-linguísticas (THOMAS, 1995, 
p.58). Assim, um interagente apresenta implicaturas a partir das pressuposições que possui para que o outro faça as suas inferências a fim de haver compreensão mútua. (Ibid, pp. 58-61)

Coscarelli (2002, p. 02) entende que as inferências são operações cognitivas que o leitor realiza para construir proposições novas a partir de informações que ele encontrou no texto. Além disso, essa autora (ibid, p. 12) afirma que inferências são informações, incorporadas à representação mental do texto, geradas a partir de informações ativadas durante a leitura. Tais conceitos afastam-se, em parte, da perspectiva sociointeracional deste trabalho, uma vez que as inferências não são construídas somente por meio de operações cognitivas, mas também pelos aspectos socioculturais e contextuais. Compreende-se que o processamento cognitivo constitui elemento importante e possui vários estudos a respeito desse processo, como os estudos acerca dos espaços mentais, conduzido por Fauconnier (1994), além de outros estudos de Fauconnier e Tunner (2002 e 2008) e Fillmore (1976 e 1982). Entretanto, este trabalho privilegia os estudos que compreendem os aspectos sociocognitivos na realização das inferências.

Cook, Limber e O’Brien (2001. p. 220) avaliam ser necessário, no âmbito da compreensão leitora, entender como alguns tipos de inferências são realizadas pelos leitores. Dentre as classificações apresentadas pelos autores, destacam-se as inferências necessárias e as elaborativas. As inferências necessárias compreendem aquelas requeridas para compreensão completa, já as elaborativas são aquelas que não são prioritariamente necessárias à compreensão, mas que, quando realizadas, expandem e embelezam o que já havia sido indicado ${ }^{15}$. (Ibid, p. 220)

Nota-se a presença dessas duas modalidades de inferências, propostas por Cook, Limber e O'Brien (2001), nas atividades de compreensão de textos realizadas pelos colaboradores desta pesquisa. Todavia, é preciso salientar que tal classificação não abarca todas as relações entre os sujeitos que participam do processo de compreensão textual, pois esses autores propõem uma análise mais centrada nas relações estabelecidas tão somente entre o texto e o leitor. Ao contrário disso, este estudo pretende identificar como ocorre o processo de compreensão leitora por meio da realização das inferências que possuem precedentes como cultura, conhecimentos prévios e aspectos interacionais que acontecem durante a interação entre texto/autor/aluno-leitor/professora-pesquisadora.

A respeito disso, Leffa (1996b, pp. 153-154) trata das visões micro e macro que se deve ter acerca das inferências. $\mathrm{O}$ aspecto micro corresponde às investigações voltadas para

\footnotetext{
15 Tradução própria.
} 
os aspectos somente cognitivos que envolvem a compreensão textual, privilegiando, nesta perspectiva de análise, a relação texto e leitor. Já na visão macro, há a preocupação de investigar não somente o léxico e as estruturas sintáticas que corroboram para construção da significação do texto (análise da microestrutura), mas principalmente de analisar uma abordagem maior (macroestrutura textual).

O texto passa a ser visto mais no seu todo do que nas suas partes e a compreensão não é apenas um processo linear, onde se apreende sequencialmente pequenas porções do texto, mas também um processo de visualização global, com apreensão não-linear de segmentos selecionados. (LEFFA, 1996b, p.153)

A concepção de inferência em Leffa (1996b) inicia discussões mais voltadas à associação dos aspectos internos e externos que envolvem o processo de compreensão leitora, mas elas não avançam em direção ao aspecto sociocognitivo aqui adotado. Por essa razão, os estudos de Marcuschi (2007a, 2008), Koch (2002, 2009a e 2014), Koch e Elias (2006), harmonizam-se com a proposta defendida neste trabalho, pois compreendem a inferenciação como atividade discursiva.

Marcuschi (2008, p. 248) defende o ponto de vista de que compreender é inferir aquilo que o outro quer dizer. As inferências, para ele, convocam os aspectos de compreensão de texto, que não podem ser relacionados tão somente a aspectos linguísticos. Aspectos antropológicos, psicológicos e factuais fazem parte do processo tão complexo que envolve a compreensão do texto.

\footnotetext{
As inferências são, pois, processos cognitivos nos quais os falantes ou os ouvintes, partindo da informação textual e considerando o respectivo contexto, constroem uma nova representação semântica (...). As inferências introduzem informações por vezes mais salientes que as do próprio texto. (MARCUSCHI, 2008, p. 249)
}

As inferências, por essa razão, possuem bases lógicas, semânticas, pragmáticas e cognitivas. Assim, o sentido é resultado da explicitação de inferências discursivamente produzidas, e, para que um enunciado possa ser entendido por mais de um sujeito, ele deve permitir a projeção de sentidos. (MARCUSCHI, 2007a, p. 88)

Entende-se que a inferenciação se constitui não apenas como atividade voltada para a interação dos alunos com os textos trabalhados em sala de aula, mas acrescentam-se a esta análise as interações entre pesquisadora/alunos, alunos/alunos e alunos/produções escritas, pois todas as interações estabelecidas durante o processo de compreensão textual, sendo orais ou escritas, constituíram material essencial para este estudo, pois parte-se do pressuposto de 
que todas as atividades de compreensão textual realizadas em sala de aula devem priorizar a relação dialógica entre esses atores sociais e os textos lidos e debatidos.

Uma questão importante abordada por Koch (2014, p. 143) é que as representações mentais devem fazer parte dos estudos sobre inferência, pois dizem respeito à relação entre as inferências e as estruturas cognitivas ativadas durante o processamento do texto, bem como aos tipos de relação existentes entre as inferências produzidas e a representação mental construída pelo interlocutor durante a compreensão (ibid, p. 43). Dessa forma, as inferências são vistas, por essa autora, como processos cognitivos através dos quais os interagentes partem de uma informação textual explicitamente veiculada e ligada ao contexto para a construção de representações semânticas. (Ibid, p. 43)

Essas informações são processadas semanticamente de maneira seletiva para que as inferências tornem disponíveis as informações antigas e novas. Koch (Ibid, p. 44) questiona se esse processo inferencial acontece em qualquer ponto do processamento mental ou se ele se realiza quando há necessidade de recobrir uma lacuna do texto. Os dados desta pesquisa revelam que ambas as assertivas são plausíveis, pois os processos inferenciais ocorrem nos momentos das atividades escritas de leitura e compreensão textual, como também quando os alunos expressam suas dúvidas e as discutem com a professora e com os colegas. Do mesmo modo, a pouca participação dos alunos durante a discussão do texto 02, mais adiante, no Excerto 03 (p. 42-43), revela o desconhecimento, por grande parte desses estudantes, dos objetos de discurso mais partilhados pelo autor da charge apresentada a seguir.

Texto 02 - Charge

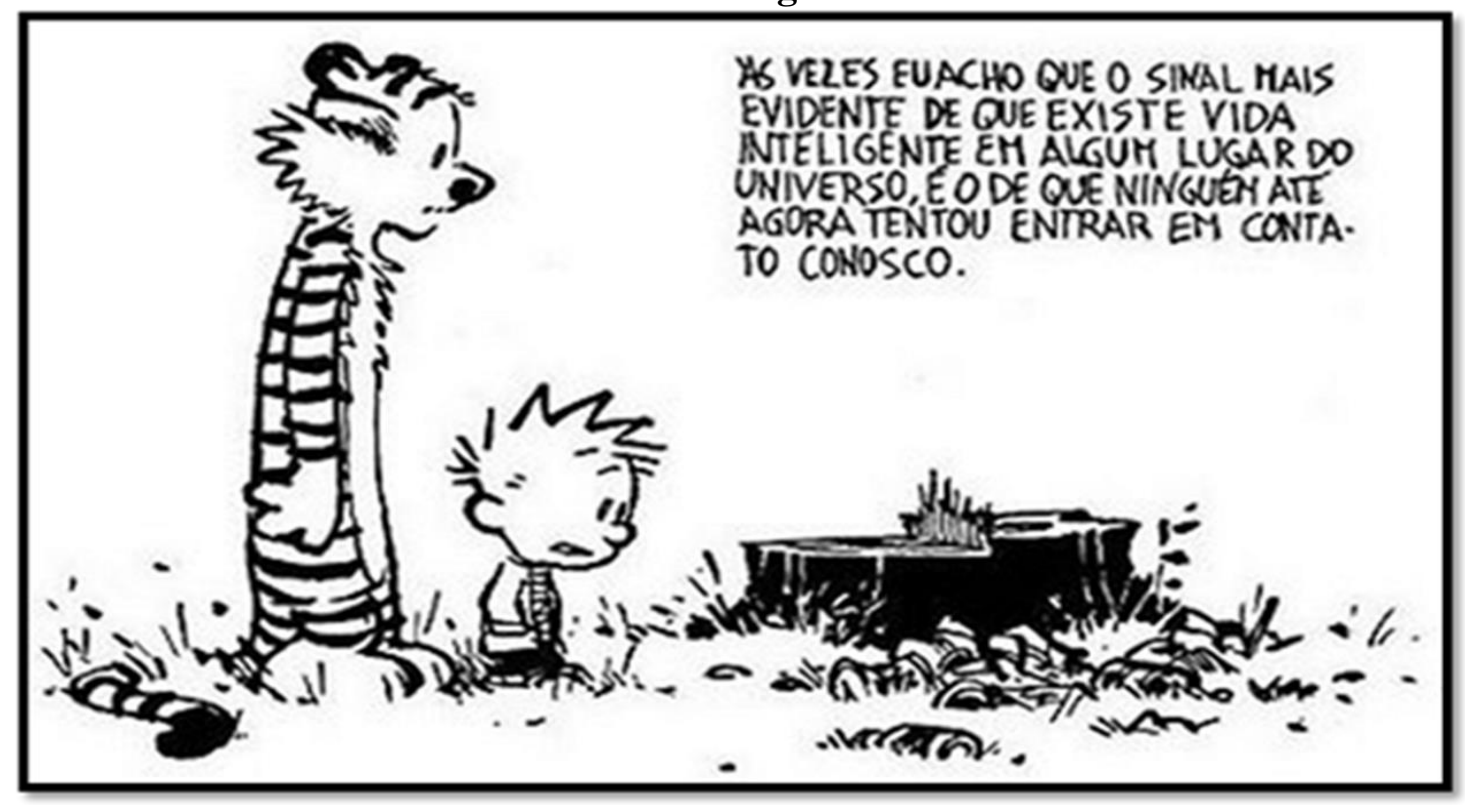

Disponível em: http://sociometricas.zip.net/arch2009-0. Acesso em 13/03/2015 
A diversidade de inferências realizadas na atividade escrita indica as várias inferências realizadas pelos alunos, decorrentes de diferentes pressuposições e implicaturas advindas, na maioria das vezes, da escassez de referências sobre os personagens de Bill Watterson, Calvin e Haroldo. Tal desconhecimento conduziu boa parte dos estudantes a voltarem seus olhares para Haroldo como um tigre de verdade, e não como um bicho de pelúcia e amigo imaginário de Calvin.

Nesta produção (Figura 01), a aluna 02 expressa sua compreensão prévia da charge de Watterson e percebe-se que as referências foram realizadas pela apropriação do texto, pois não havia, até aquele momento, elementos de discurso que corroborassem a construção de outras inferências diante do texto.

Figura 01 - Texto da aluna 02 sobre o texto 02 - atividade escrita 01.

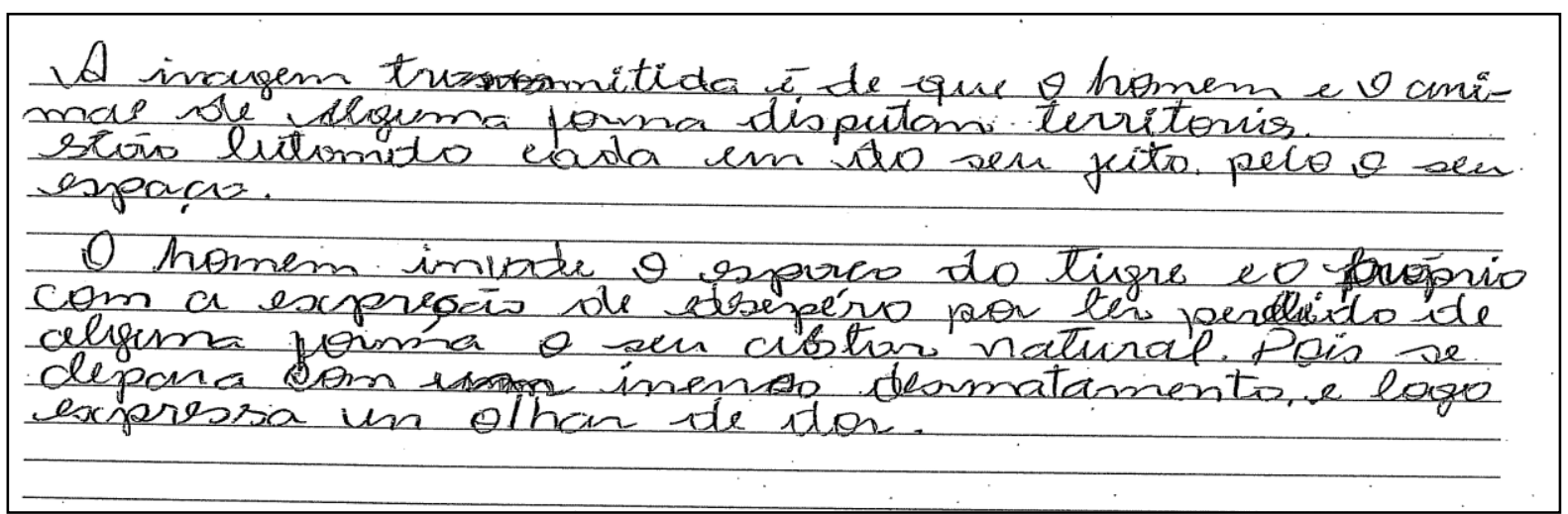

Fonte: textos produzidos pelos colaboradores de pesquisa.

Outra conclusão a que se pode chegar sobre a compreensão textual da aluna 02 é o modo como a imagem constitui elemento semiótico fundamental na construção do sentido. Quando a aluna não possuía apoio referencial que a fizesse compreender o sentido da charge por meio da fala dos personagens, ela se ateve à ilustração e a tomou como recurso único de compreensão da charge. Isso fica claro quando, no primeiro período construído, a estudante tratou da disputa de território entre o homem e o animal (linhas 01 e 02). No segundo parágrafo (linha 06-10), a discente já voltou o olhar para a árvore cortada e ressaltou a desolação do tigre com a ação do homem sobre a natureza.

Já a aluna 05 (Figura 02) voltou sua atenção para a imagem e para elementos do texto escrito, mas não conseguiu ampliar as inferências por não possuir referências sobre quem eram os personagens da charge. 
Figura 02 - Texto da aluna 05 sobre o texto 02 - atividade escrita 01.

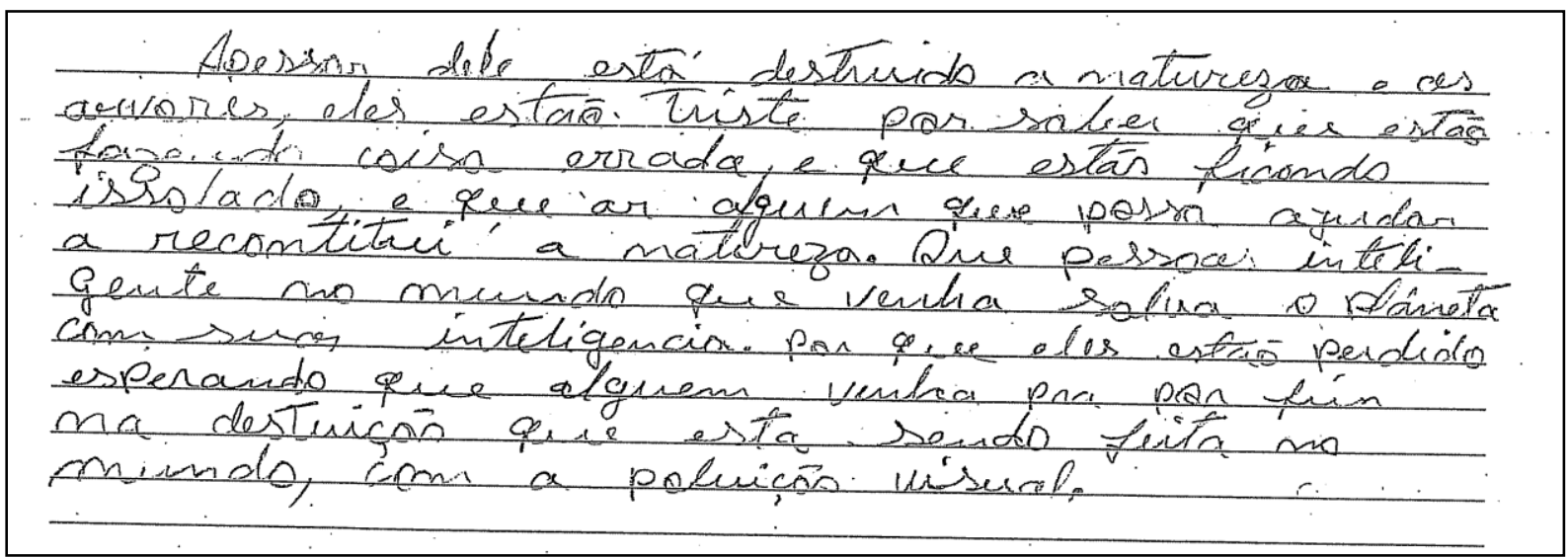

Fonte: textos produzidos pelos colaboradores de pesquisa.

A discente inferiu que, em vez de Calvin e Haroldo estarem refletindo sobre o que o ser humano tem provocado no meio ambiente, eles é que foram agentes da destruição, de modo que a expressão deles demonstrava arrependimento (linhas 01-03). Porém, apresenta breve discussão sobre o texto escrito da charge (linhas 05-07), mas, mesmo assim, não se refere a pessoas inteligentes em outros lugares do universo, mas neste mundo (linha 06).

Percebe-se, assim, que o processo inferencial é responsável pela organização de sentidos do texto a partir dos processamentos cognitivos aliados ao conhecimento contextual que o leitor possui, de modo que ele tenha a competência de responder a perguntas sobre o texto, recordar ou resumi-lo, realizar declarações sobre o assunto abordado (...). (KINTSCH, 1988, p. 163)

Considera-se também a grande relevância do processo de ancoragem entre o texto verbal e a imagem, pois o texto verbal elabora os muitos e vagos sentidos evocados pela imagem, permitindo múltiplas hipóteses de leitura que somente a leitura do texto verbal restringiria (KLEIMAN, 2004, p. 18). A compreensão leitora de textos que apresentam formas imagéticas e verbais ancoradas exige do aluno-leitor a associação como estratégia de compreensão textual, e nem sempre esse processo ocorreu, como pôde ser observado nos textos produzidos pelas alunas (Figuras 01 e 02).

Toda compreensão será atingida mediante processos em que atuam planos de atividades desenvolvidos em vários níveis e em especial com a participação decisiva do leitor ou ouvinte numa ação colaborativa. Aqui poderíamos adotar a metáfora da construção. A língua é vista como atividade, e não como instrumento; uma atividade sempre interativa, ou seja, o processo de compreensão se dá como uma construção coletiva. (MARCUSCHI, 2008, p. 238) 
Desse modo, retoma-se a afirmação de Marcuschi (2008), apresentada no início desta subseção, de que a capacidade inferencial está relacionada ao ato de compreender, e acontece em atividades cooperativas. Portanto, o sentido não está no texto, nem no leitor, nem no autor, mas numa complexa relação interativa de negociação entre esses três elementos. (Ibid, p. 248)

As informações textuais prévias — backgrounds — aliadas às informações fornecidas pelo texto durante as práticas de leitura estão relacionadas ao maior ou ao menor número de inferências realizadas durante o processamento textual. Quanto mais informações textuais prévias o leitor possuir, mais amplas serão as referências e, consequentemente, a produção de inferências (KOCH, 2014, p. 151)

Marcuschi (2008, p. 239) apresenta, de maneira sucinta e completa, os principais aspectos relacionados à compreensão textual que precisam ser levados em consideração por pesquisadores e professores que compreendem a atividade textual como atividade interativa. Elas podem ser resumidas da seguinte maneira:

1) ler e compreender são equivalentes - a leitura, deste modo, precisa significar uma atividade de compreensão que não acontece de uma hora para outra, mas de modo processual;

2) compreender o texto é um processo cognitivo, mas também social;

3) atividades inferenciais são desenvolvidas no processo de compreensão - nessas atividades as informações são ativadas a partir de conhecimentos adquiridos no texto e também dos conhecimentos sociais;

4) os conhecimentos prévios exercem uma influência muito grande no processo de compreensão do texto. Incluem-se como conhecimentos prévios:

(a) conhecimentos linguísticos;

(b) conhecimentos enciclopédicos (factuais);

(c) conhecimentos específicos (pessoais);

(d) conhecimentos de normas institucionais, culturais e sociais;

(e) conhecimentos lógicos (processos).

5) compreender um texto não equivale a decodificar mensagens — trata-se, pois, de um processo complexo, que emprega diversas ações de ordem cognitiva e interacional.

Todos esses conhecimentos são gerados por meio dos diversos tipos de inferências que são estrategicamente classificadas por Marcuschi $(2008$, p. 254) por meio do quadro geral das inferências (Figura 03). 
Figura 03 - Quadro geral de inferências.

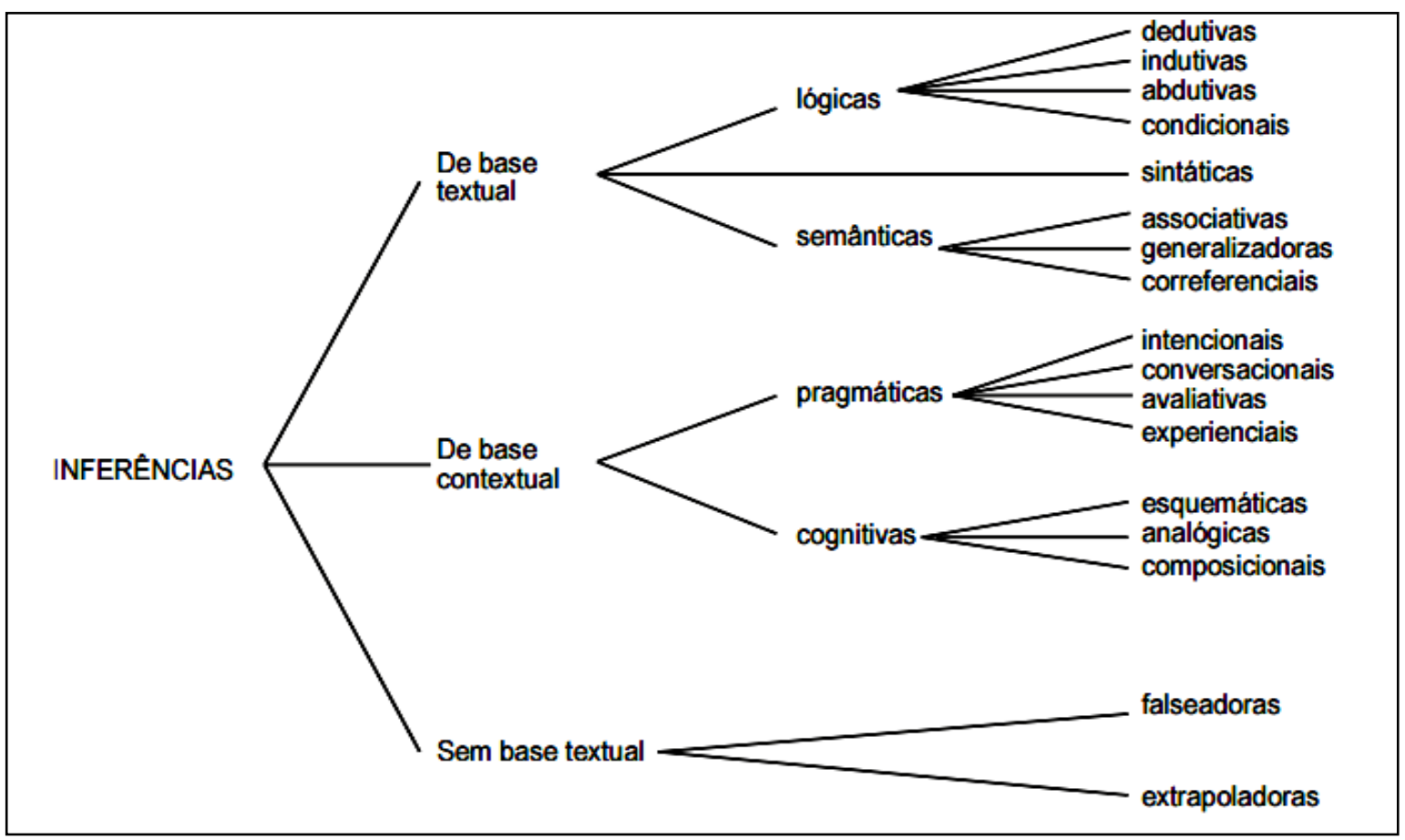

Fonte: Marcuschi (2008, p. 254)

As inferências se originam por bases textuais, quando, durante a leitura, são ativados processos cognitivos lógicos e semânticos estabelecidos pelo material linguístico disponível no texto. Elas também possuem bases contextuais, que são ativadas por meio das operações intelectuais (cognitivas) e pelas atividades de interação social e de relação com o mundo (Pragmática). Inferir também significa, algumas vezes, não só extrapolar os limites estabelecidos pelo tema do texto, como também construir sentidos sem a base textual (de forma descontextualizada do texto).

As alunas 02 e 05 (Figuras 01 e 02) construíram suas inferências a partir de bases textuais, quando observaram as imagens e tentaram, mesmo sem grande sucesso, relacioná-las ao conteúdo verbal da charge. Além disso, fizeram inferências de base contextual quando utilizaram termos como desmatamento, destruição da natureza, salvar o planeta.

Já a aluna 05 finalizou seu texto afirmando que a destruição do mundo ocorre por meio da poluição visual, sendo essa uma temática que muito se distanciava do contexto discursivo da charge, mas que poderia ter sido levantada pela aluna por alguma relação entre poluição visual e destruição do meio ambiente. Na Figura 04, que segue, a aluna 11 também realizou inferências sem base textual. 
Figura 04 - Texto da aluna 11 sobre o texto 02 - atividade escrita 01

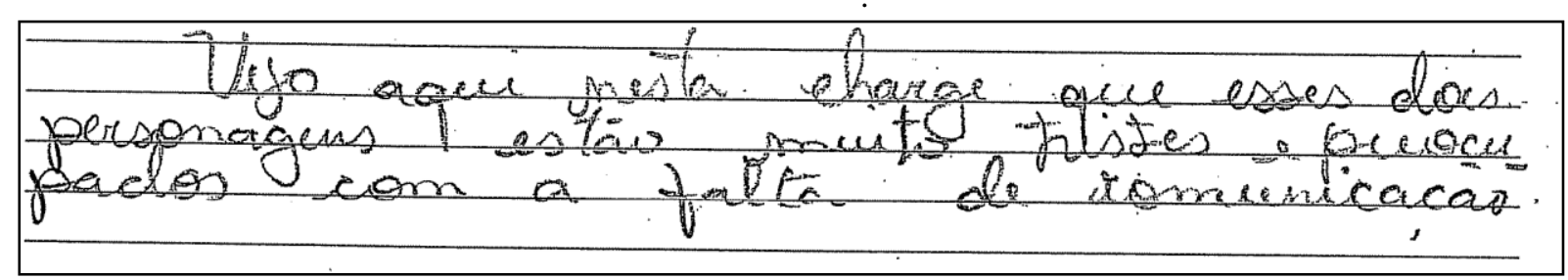

Fonte: textos produzidos pelos colaboradores de pesquisa.

$\mathrm{Na}$ verdade, a aluna 11 tentou construir a compreensão do texto mediante uma leitura superficial do conteúdo linguístico (verbal e não verbal) dentro do qual havia a expressão “... ninguém até agora entrou em contato conosco". A noção de "contato" fez com que a aluna, por falta de conhecimentos prévios (enciclopédicos, pessoais, sociais ou lógicos), realizasse inferência que extrapolou o conteúdo do texto, o que tornou a compreensão textual incoerente.

As observações feitas até aqui poderiam parecer apenas avaliativas, se o objeto de estudo deste trabalho não fosse revelar como as atividades de leitura e de compreensão textual não ocorrem em um só momento, mas em vários. Todas as interações realizadas em sala de aula, voltadas para a construção colaborativa de sentidos para os textos, servem como setas que vão fazendo, aos poucos, os alunos avançarem no longo caminho da compreensão textual. Por essa razão, entende-se a compreensão textual não como fim, mas como processo.

À primeira vista, os textos expostos nas figuras 01, 02 e 04, se fossem utilizados como único modo de analisar e de classificar as inferências, veiculariam uma prática que não condiz com os objetivos desta pesquisa. Por isso, faz-se necessário apresentar alguns excertos dos momentos de discussão que aconteceram na aula posterior às produções para perceber como as atividades coletivas constituem momentos importantes para a ampliação do conhecimento.

\section{Excerto 03 - Aula 03}

01 Professora: /.../ o Calvin ele é um menino, ele é uma criança, /.../ o personagem é uma criança

02 de cinco anos, e esse aqui é um, é o que que vocês acham que ele é?

03 Aluna 17: Tigre.

04 Professora: É um tigre, não é? /.../ o Haroldo é um tigre de pelúcia do Calvin, é um tigre de 05 pelúcia, mas vocês sabem que a criança é, ela tem o quê?

06 Aluna 18: Amigo imaginário.

$$
\text { /.../ }
$$

07 Aluna 19: Parece ( ) assustado o tigre.

\section{/.../}

08 Professora: /.../ vocês não tinham esse conhecimento de quem era Calvin, de quem era o

09 Haroldo, agora vocês têm esse conhecimento e nós vamos fazer uma outra leitura, é... uma coisa

10 também que é muito, que é muito própria da tira do Calvin é o seguinte é, é... que o que ele fala

11 é muito importante, o texto é muito importante, você tem que ler o texto com muita atenção e

12 tem que observar a imagem com muita atenção /..../ 


\section{I.../}

13 Aluna 19: Eu acho que ele fala que as pessoas aqui realmente não são inteligentes porque ele tá

14 diante da árvore ali, a árvore foi derrubada né? Se existisse essa inteligência, ninguém teria 15 derrubado.

16 Aluna 20: Mais inteligente do que a gente, né?

17 Professora: O que é vida inteligente? Vida inteligente não é a vida de alguém que raciocina, /.../

18 Então ele está achando nesse momento de que nós, seres humanos, moradores do planeta Terra,

19 não temos a inteligência, uma inteligência suficiente pra perceber o mal que nós estamos

20 causando pro Planeta e ele tá dizendo o seguinte, que se existir vida em outro planeta, vida

21 inteligente em outro local do universo essas pessoas não vão querer entrar em contato conosco

22 não, por quê?

22 Aluna 20: Estamos destruindo a nossa vida.

$\mathrm{Na}$ interação em sala de aula retratada nesse excerto, a professora-pesquisadora realizou explanação acerca dos quadrinhos do Calvin, sua distribuição pelo mundo e as características principais desse personagem. Nas linhas 01 a 07, a pesquisadora apresentou Haroldo, o tigre de pelúcia e amigo imaginário de Calvin e, ao perceber que os alunos não possuíam conhecimento prévio durante as correções de texto, julgou importante apresentar essas informações para que eles pudessem ampliar a visão em relação ao texto em foco.

Nas linhas 08 a 12, a professora justificou toda explanação, na qual apresentou informações a respeito dos personagens da charge e chamou a atenção para as características de quadrinhos desse tipo, que exigiriam dos leitores bastante atenção não somente para um aspecto, mas para os aspectos verbais e não verbais, haja vista que, em textos como aquela charge, perceber a ancoragem entre esses dois aspectos é bastante importante para a compreensão.

A partir de então, a professora começou a obter mais respostas das alunas presentes. Entende-se, assim, que providas de conhecimentos acerca do texto, as alunas presentes passaram a fazer mais comentários, por se sentirem mais seguras.

Durante a realização do grupo focal, as alunas participantes, ao serem solicitadas a relatar o que haviam compreendido acerca dessa charge, responderam o seguinte:

\section{Excerto 04 - Grupo Focal}

01 Professora: Então, a primeira coisa assim que veio à sua mente. Tá e aí, depois, né, de eu ter

02 entregue pra vocês. Na aula posterior, eu entreguei, coloquei no quadro os slides e aí a gente... E

03 aí, como é que foi? Aí, depois daquela conversa, como vocês passaram a compreender esse texto? I.../

04 Aluna 6: Eu entendi também que assim, hoje em dia, as pessoas racionais, elas não estão olhando

05 pra esse lado, porque aí é uma criança, que não tem nada a ver, e o animal, que tão realmente

06 preocupado quando deveria ser as pessoas adultas, pessoas que têm raciocínio. Ele é de brinquedo

07 ((apontando para o tigre)), mas para ele tem vida. 
O relato da aluna 06 indicou o reconhecimento de que Haroldo, o tigre de Calvin, era um animal, mas de brinquedo e também estava preocupado com a situação do meio ambiente. Houve, no comentário dessa aluna, acréscimo de inferências em relação ao modo como compreendeu inicialmente o texto 02 (Figura 05).

\section{Figura $05^{16}$ - Texto da aluna 06 sobre o texto 02 - atividade escrita 01}

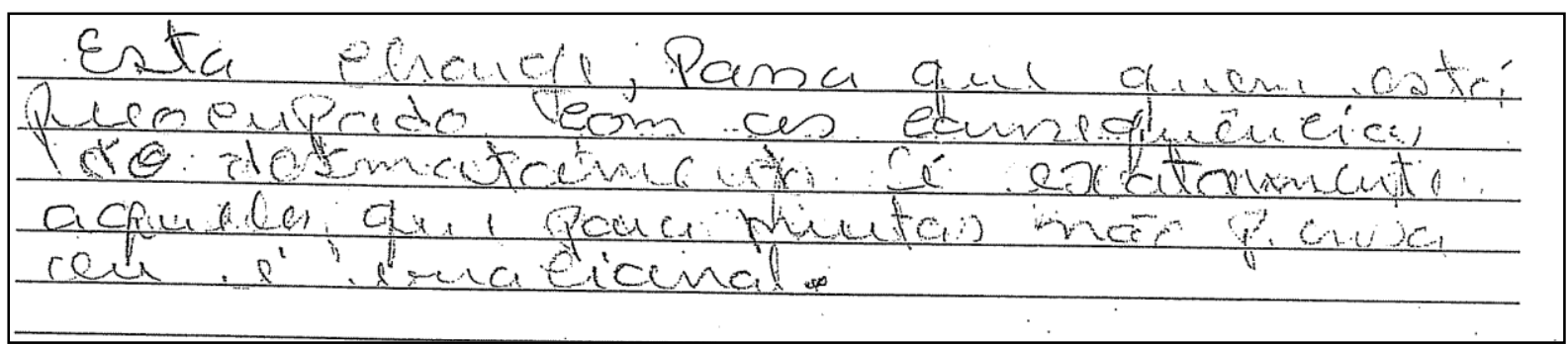

Fonte: textos produzidos pelos colaboradores de pesquisa.

Na Figura 05, encontra-se o primeiro relato da compreensão da aluna 06. Ela explica que quem está preocupado com as consequências do desmatamento é [sic] exatamente aqueles que para muitos não precisa [sic] ou é irracional. Então, aquele que não precisa, seria a criança, e o irracional seria o tigre, que, até aquele ponto, tratava-se de um ser irracional para aluna, pois, até então, ela não possuía conhecimento a respeito dos personagens do cartunista Bill Watterson.

As análises realizadas reforçam o caráter processual da compreensão textual. É preciso que o professor analise, de início, as diversidades de inferências realizadas pelos alunos, que percorrem um contínuo de maior ou menor aproximação com os sentidos do texto. Essa aproximação ou esse distanciamento dependerá de fatores muito mais contextuais que somente textuais ${ }^{17}$.

Van Dijk (1992, p. 110) defende que a cognição social deve ser analisada considerando a interface entre discurso e sociedade. Assim, há de se levar em consideração os sujeitos e os grupos sociais dos quais fazem parte os alunos para compreender o processo de construção de sentido do texto. Desse modo, a cognição social envolve um sistema de estratégias mentais e de estruturas partilhadas pelos membros do grupo, e em particular

\footnotetext{
${ }^{16}$ Texto da aluna 06 sobre o texto 03 , da atividade 01 (com alguns ajustes referentes à norma padrão): Essa charge passa que quem está preocupado com as consequências do desmatamento são, exatamente, aqueles que, para muitos, não precisam ou são irracionais.

${ }^{17}$ No capítulo 04 deste estudo (item 4.4.3), o contínuo de aproximação ou distanciamento dos sentidos do texto será discutido e analisado a partir das respostas que os alunos forneceram na primeira atividade de compreensão textual, tendo o embasamento das teorias de Vogt (1980) e Koch (2009c).
} 
aqueles que estão envolvidos na compreensão, produção ou representação de objetos sociais, tais como situações, interações, grupos e instituições. (VAN DIJK, 1992, p. 110)

Esse autor (ibid, p. 110-111) afirma que a memória de longo prazo, formada pelo conjunto de experiências pessoais e compartilhadas pelos grupos sociais e baseadas em representações mentais de episódios particulares, alia-se com a memória de curto prazo, estabelecida pelas operações estratégicas, com base nos modelos da memória de longo prazo, tais como percepção, produção de discurso e compreensão.

Portanto, as inferências: (1) são fundamentadas por conhecimentos partilhados, sendo grande parte deles construções socioculturais; (2) envolvem processos atribucionais, quando há atribuição de causas para certas condições; (3) baseiam-se em estruturas pessoais, incluindo a representação cognitiva de estereótipos, como, por exemplo, grande parte das inferências realizadas a respeito do texto 02 tinha em comum a ideia de que "o homem destrói a natureza”. (Cf. MARCUSCHI, 2008)

A leitura, para Koch e Elias (2006, p. 37), constitui uma atividade de construção de sentido, que envolve autor-texto-leitor e que, além das pistas e sinalizações oferecidas pelo texto, são inseridos os conhecimentos dos leitores, que podem auxiliar ou embargar a compreensão, como foi demonstrado nesta seção. Desse modo, defende-se uma interação que perpasse a relação única de autor-texto-leitor. Nessa proposta, incluem-se as seguintes atitudes: (1) percepção do professor acerca do nível de compreensão textual de cada aluno, por meio da verificação prévia em atividades escritas de produção de sentido; e (2) atividades de leitura coletiva e mediadas pelo professor, o qual irá fornecer pistas linguísticas quando detectar que os sentidos do texto não foram percebidos integralmente pelos estudantes.

\subsection{Pistas de contextualização e construção dos andaimes}

Nesta seção, serão pormenorizadas as bases teóricas que sustentam o argumento de que as inferências podem ser ampliadas se houver situações que permitam o diálogo mediado pelo professor. Tem-se em Gumperz (1982a), Bruner (1983), Van Dijk (1992, 2008 e 2009) e Duranti \& Goodwin (1992) os principais postulados de que o contexto é responsável pela negociação dos sentidos, pela ampliação dos objetos de discurso e pela efetivação da cognição social. Em razão disso, faz-se necessário situar as noções de contexto que se coadunam com as bases teóricas desta pesquisa. 
Quando se reconhece linguagem como ação social, os sentidos dos textos, sejam eles escritos ou falados, verbais ou não verbais, precisam ser construídos considerando-se os contextos que os envolvem. Os objetos de discurso são, por essa razão, construídos pelo contexto enunciativo.

Van Dijk (2008, p. 05) entende que é impossível compreender algo sem que os participantes compreendam o contexto. Por isso, para esse autor (2009, p. 29), os contextos são definidos não somente como modelos mentais das situações comunicativas, mas que também são constituídos na interação contínua dos participantes os quais incorporam aspectos das suas identidades sociais. Desse modo, a cognição é socialmente compartilhada pelos atores sociais que constroem, por meio das práticas discursivas, o contexto. (VAN DIJK, 2009, p. 31)

Duranti \& Goodwin (1992, pp. 02-03) usam o termo "evento focal” para caracterizar os estudos do contexto. Delinear o que é focal e o que é background constitui, para esses autores, um dos principais desafios para pesquisadores. A questão é que um evento não pode ser compreendido olhando somente para ele, mas é necessário analisar aspectos como cenário cultural, situação de fala, pressupostos compartilhados (ibid, p. 03). Além disso, é preciso considerar o ponto de vista do participante, pois as percepções que ele constrói a respeito das situações servem de delimitação para compreender o contexto.

Nessa perspectiva, o contexto é dinâmico e se atualiza a todo instante, pois é construído e reconstruído pelos atores sociais, que o modificam de acordo com as mudanças de frame que são sinalizadas, na situação, por meio das pistas de contextualização. (GUMPERZ, 1982a)

Ao perceber o contexto no rol das interações sociais, Gumperz ([1982a]2002, p. 08) apresenta as pistas de contextualização, que constituem pistas linguísticas, verbalizadas ou não, que instigam os interagentes a negociarem significações durante a interação (ibid, [1982a] 2002, p. 08). Esse conceito considera as premissas de que (1) uma interpretação sempre dependerá do contexto em que os atos de fala ocorrem e que (2) os pressupostos contextuais moldam a interpretação dos interagentes.

As pistas de contextualização constituem, assim, quaisquer recursos ou formas linguísticas que contribuem para a sinalização das pressuposições contextuais. São, dessa forma, caracterizadas na superfície das mensagens, constituindo a maneira como os interlocutores sinalizam e os ouvintes interpretam os sentidos das atividades interacionais por meio dos conteúdos semânticos presentes nas sentenças. (GUMPERZ, 1982a, p. 131) 
Essas pistas facilitam o processo de compreensão, haja vista que os interagentes, quando as fornecem, compartilham conteúdos linguísticos para a compreensão do contexto. Todavia, quando um interagente não compreende as pistas fornecidas pelo outro, ocorrem os mal-entendidos e, para que eles sejam superados, faz-se necessário negociar ainda mais os sentidos do texto (GUMPERZ, 1982a, p. 132). Por essa razão, a interação face a face se torna imprescindível para os alinhamentos da compreensão textual, que não seriam possíveis se esse processo se restringisse unicamente a atividades individuais ou a instruções monológicas fornecidas pelo professor.

Durante as atividades colaborativas desenvolvidas no curso das aulas, houve muitos momentos nos quais a professora-pesquisadora precisou apresentar pistas para que os alunos pudessem ampliar, por eles mesmos, a compreensão dos textos discutidos. Esse modo de amadurecimento do saber abarca a noção de Vygotsky (1991, p. 58) da zona de desenvolvimento proximal $^{18}$. Os estudantes, por meio da interação estabelecida com os textos, constroem inferências que os levam ou não a compreender o texto. Quando as pistas fornecidas pelo texto não são suficientes para gerar compreensão, em razão de diversos fatores, tais como ausência ou quantidade insuficiente de referências contextuais, o interagente mais experiente, que pode ser um colega ou o professor, entra em cena oferecendo pistas para enquadrar o outro no contexto e permitir que haja interação com os objetos de discurso dos textos.

Fundamentado na noção de zona de desenvolvimento proximal (ZDP) de Vygotsky, Bruner (1983) desenvolve a proposta da construção de andaimes ${ }^{19}$, que muito se assemelha à concepção de ZDP, mas que, segundo esse autor (1986, p. 74), amplia essa noção, o que é confirmado por meio de várias pesquisas que demonstram como os adultos (mais experientes) fornecem andaimes e de que modo eles contribuem para a construção da aprendizagem das crianças ou dos interagentes menos experientes.

A teoria da construção dos andaimes é bastante utilizada em contextos educacionais, pois foi, em grande parte dos trabalhos de Bruner, aplicada a contextos de interação professoraluno. Wood, Bruner \& Ross (1976, p. 89) revelam que a construção de andaimes está

\footnotetext{
${ }^{18}$ A Zona de Desenvolvimento Proximal (ZDP) se refere à distância entre a zona de desenvolvimento real aquilo que o sujeito consegue compreender sozinho, e a zona de desenvolvimento potencial — aquilo que consegue aprender por meio do auxílio de um interagente com mais experiência a fim de resolver um determinado problema (VYGOTSKY, 1991). Esse conceito será aprofundado no capítulo 02 deste trabalho.

${ }^{19}$ O termo "andaime" (scaffolding, no original) é muito utilizado na construção civil. Bruner (1983 e 1986) e Wood, Bruner \& Ross (1976) adotaram-no para indicar que toda aprendizagem constitui processo de construção pessoal e inclui a ajuda de outros interagentes mais experientes no fornecimento de andaimes para consolidação e desenvolvimento do saber dos menos experientes.
} 
envolvida num processo tutorial, no qual adultos ou os "mais experientes" ajudam os "menos adultos" ou os "menos experientes" a atingirem determinada meta que seria impossível sem o apoio do outro.

Desse modo, o fornecimento de andaimes envolve a liderança do interagente com mais experiência no processo de resolução dos problemas que estão além da capacidade inicial dos alunos, e pode oferecer a eles muito mais que uma simples ajuda na resolução de uma tarefa, pois essa prática conduz os alunos a desenvolverem-se num ritmo muito além daquele que eles imaginariam estar (ibid, p. 90) e, por essa razão, beneficia todos os envolvidos no processo.

As teorias de Gumperz (1982a), Bruner (1983 e 1986) e Wood, Bruner \& Ross (1976) demonstram que as pistas de contextualização são instrumentos por meio dos quais os andaimes são fabricados e utilizados pelos alunos na resolução de problemas e na descoberta de informações que fornecerão a eles referências contextuais que serão úteis na compreensão dos textos.

No excerto a seguir, há um dado que ilustra do processo de resolução de problemas por meio do fornecimento de pistas pela professora-pesquisadora, permitindo a construção de andaimes pelos alunos.

\section{Excerto 05 - Aula 05}

01 Professora: /.../ ele apresenta quais foram esses fatores, gente, ele começa com qual fator? O 02 primeiro.

03 Aluna 05: Verticalização.

04 Professora: Verticalização, o que é verticalização?

05 Aluna 06: Alguma coisa que fica na vertical?

06 Professora: E o que fica na vertical?

07 Aluna 07: A chuva.

08 Aluno 03: O barranco.

09 Professora: O barranco? Não daria para a gente pensar também numa outra, um outro fator de 10 verticalização das grandes cidades?

11 Aluna 07: Seria a falta...

12 Aluno 03: Ah, seria...

13 Aluna 07: Seria a falta do verde?

14 Professora: A falta do verde, e a falta do verde é o que mesmo /.../?

15 Aluno 03: As construções.

Nesse momento da aula 05, a professora estava realizando leitura mediada com a turma a respeito do texto $O$ Fundo do Poço (Anexo II). Esse texto apresentava alguns fatores que levaram à crise hídrica no Estado de São Paulo. Um deles era a verticalização. 
Percebendo que os alunos poderiam não ter compreendido o sentido desse termo, pois não o haviam utilizado na produção textual realizada na aula anterior, a professora resolveu inquirilos acerca do significado da palavra.

A primeira inferência, após o questionamento da pesquisadora, foi o da aluna 06 que, utilizando seus conhecimentos linguísticos, relacionou verticalização àquilo que se encontra na vertical. A aluna 07 ligou verticalização à chuva, e o aluno 03, a barranco. A professora tomou o turno e forneceu a pista verticalização das grandes cidades. Depois disso, a aluna 07 reiniciou sua inferência, porém, com dificuldades de continuar o processo. $\mathrm{O}$ aluno 03 também iniciou a fala, porém não conseguiu finalizá-la; posteriormente, a aluna 07 fez outra inferência relacionada às questões do meio ambiente em forma de pergunta: seria falta de verde? (linha 13); e, por fim, a pesquisadora forneceu a última pista utilizando a inferência realizada pela aluna 07 no turno anterior, o que fez o aluno 03 relacionar verticalização com as construções nas grandes cidades.

Como afirma Blommaert (2008, p. 107), nem todo contexto élestá acessível a todos, e, por esse motivo, é necessário que o processo de negociação entre professores e alunos ocorra para que os interagentes que não conseguiram se enquadrar ao contexto possam compreendêlo, por meio do processo da construção dos andaimes e do fornecimento das pistas de contextualização, assim como ocorreu na interação apresentada no Excerto 05. Houve, nesse momento da aula, a construção cognitiva crítica, graças ao diálogo colaborativo estabelecido entre a professora-pesquisadora e os alunos. Todas as inferências realizadas pelos alunos não foram descartadas, mas serviram como base para o avanço coletivo da construção do contexto. Sendo assim, é possível compreender que as pistas fornecidas pela professora pesquisadora possuíam potencial de encaminhar os estudantes à construção de inferências ${ }^{20}$.

Todo o percurso das atividades explicitado é revelador de como se desencadeou o processo de construção dos andaimes por meio do fornecimento de pistas de contextualização. Esse procedimento contribuiu para a ampliação dos objetos do discurso presentes no texto. Percebe-se que os alunos poderiam não ter oportunidade de compreender o termo verticalização se tivessem realizado uma única leitura do texto na aula anterior. Por isso, defende-se que as atividades de leitura mediada proporcionam ampliação da prática de leitura e de compreensão textual e, por essa razão, precisam compor a rotina das aulas nos cursos técnicos.

20 No decorrer deste estudo, as pistas de contextualização serão tratadas como pistas potenciais de contextualização, uma vez que elas funcionaram como gatilhos que levavam os estudantes a construírem suas inferências em níveis e em modos diversos. 


\subsection{Processos Inferenciais em Atividades Discursivas}

Nesta seção serão apresentadas e discutidas as teorias que analisam os processos inferenciais realizados pelos alunos que colaboraram com esta pesquisa. Pretende-se, a partir da discussão das teorias voltadas à sociocognição, demonstrar como a compreensão dos textos é resultado do processo de construção de inferências e envolve conceitos como: as metáforas, estudadas por Lakoff \& Johnson ([1986] 2012); a construção de narrativas (BRUNER, 1991 e 2004) e a utilização de expressões referenciais (KOCH, 2014). O estudo das inferências conversacionais (GUMPERZ, 1982a) também constitui ponto importante no estudo dos processos inferenciais, pois, nos momentos de interação face a face, os colaboradores de pesquisa e a professora-pesquisadora constroem, de forma colaborativa, o contexto e minimizam mal-entendidos relacionados aos textos.

Todas as teorias apresentadas e exemplificadas nesta subseção serão aliadas aos dados gerados e analisados e comporão a contribuição teórica deste trabalho. Esses processos inferenciais serão reapresentados, no capítulo 05 , como elementos que integrarão a proposta didática para atividades de leitura e compreensão textual no ensino técnico.

É importante ressaltar que os processos inferenciais a serem apresentados se revelaram durante a análise dos dados gerados, ou seja, eles não foram pré-estabelecidos pela professora-pesquisadora antes de ela entrar em sala de aula. Durante a geração dos dados, as interações realizadas com os alunos, bem como os textos produzidos por eles, foram revelando à pesquisadora, durante a análise dos dados, os processos inferenciais. Sendo assim, eles serão listados, a seguir, com a finalidade de conferir organização e, consequentemente, clareza ao trabalho.

\subsubsection{A metáfora no processo inferencial}

A noção aristotélica de metáfora como figura de retórica cuja função era apenas ornamentar, conforme Zanotto (1998, p. 14), perdurou por muitos séculos e, ainda hoje, permeia os ambientes escolares, como se ela fosse utilizada somente em gêneros textuais literários na função de embelezadora de textos. A partir da década de 1970, esse conceito 
começou a ser repensado nos meios acadêmicos, quando estudos começaram a perceber a ausência do valor cognitivo e da determinação (objetividade) da significação em diversos textos. Desse modo, a metáfora vem sendo reconhecida como instrumento de cognição, por desempenhar papel essencial nos processos perceptuais e cognitivos. (ZANOTTO, 1998, p. 15)

A discussão sobre como a metáfora se relaciona com a construção dos conceitos é assinalada por Lakoff \& Johnson ([1986]2012). Para esses autores (ibid, p. 43), as expressões metafóricas de uma língua encontram-se interligadas com os conceitos metafóricos de uma maneira sistemática ${ }^{21}$ e por meio de bases culturais.

Lakoff e Johnson ([1986]2012) discutem o caráter metafórico e cognitivo que rege a linguagem cotidiana. Esses autores denominaram os conceitos metafóricos presentes na realidade cotidiana dos sujeitos e que conduzem a linguagem e a ação social, ao classificarem vários tipos de metáforas conceituais, entre as quais, destacam-se as que seguem.

A primeira metáfora apresentada é a estrutural. Nela, um conceito está estruturado metaforicamente a partir de outro e pode ser estendido de certa maneira, mas, não de outras (LAKOFF \& JOHNSON, [1986]2012, pp. 49-50). Como exemplo, os autores fornecem a expressão perder tempo ou tempo é dinheiro, nas quais é expressa a ideia de que o tempo constitui recurso limitado e um objeto valioso. Por essa razão, entende-se que os valores mais fundamentais da cultura serão coerentes com a estrutura metafórica constituída. (Ibid, p. 45)

O segundo tipo de metáfora apresentada por Lakoff \& Johnson ([1986] 2012, p.50) são as orientacionais, responsáveis pela organização de um sistema em relação a outro. Essas metáforas dão ideia de relação espacial (dentro/fora; acima/abaixo; central/periférico; fundo/raso). Os autores comparam essas metáforas ao movimento dos corpos dos seres humanos, que constitui a forma como se compreendem e se relacionam com o mundo. Portanto, elas possuem existência arbitrária, assim como as metáforas estruturais, pois têm bases nas experiências físicas e culturais dos sujeitos. Desse modo, dizer que alguém está para baixo indica tristeza, depressão; assim como dizer que alguém está de bom humor equivale a dizer que a pessoa está para cima. Todavia, os autores (ibid, p. 60) deixam claro que existem culturas nas quais a relação cima/alegria e baixo/tristeza não funciona e, em relação ao que é importante para os interagentes de uma dada cultura, seus sistemas de valores individuais são coerentes com as principais metáforas orientacionais da corrente cultural em que se inscrevem.

\footnotetext{
21 Tradução própria.
} 
As metáforas ontológicas são aquelas responsáveis pela experiência humana com objetos e substâncias. Uma vez identificada a experiência com substâncias e coisas, os seres humanos passam a se referir a elas, categorizá-las, agrupá-las, quantificá-las, e, dessa maneira, raciocinar sobre elas (LAKOFF \& JOHNSON, [1986]2012, p. 63). Há, então, a necessidade de concretização das substâncias por causa da necessidade de o homem ter objetos concretos.

Então, o contexto discursivo é que definirá o sentido dessas metáforas. Por exemplo, subir o salário e subir o preço constituem sentidos completamente diferentes empregados por expressões constituídas por subir. A expressão subir o salário possui conotação positiva, para o empregado, e negativa, para o patrão; todavia, subir o preço é uma expressão que pode ser positiva para o comerciante, se ele estiver lucrando com isso, mas negativa para o consumidor. $\mathrm{O}$ mesmo ocorre com descer, pois é diferente a expressão descer do trono de descer os preços. Assim, os conceitos positivo e negativo expressos pelas metáforas orientacionais perdem o sentido quando essas expressões se aliam a outras.

Há metáforas que permitem compreender experiências de objetos não humanos com características e motivações humanas (LAKOFF \& JOHNSON, [1986]2012, p. 71) — são as metáforas de personificação. Por meio delas, entidades inanimadas tomam vida e ganham aspectos humanos que irão se diferenciar a cada contexto. Porém, as metáforas de personificação comportam-se como metonímias em muitas expressões quando a parte da expressão é tida como o todo (ibid, p.75-76). Isso pode ser observado na metáfora conceitual utilizada na parte do texto produzido pela aluna 19, expresso na Figura 6.

Figura 06 - Excerto 01 do texto da aluna 19 sobre a crise hídrica - atividade escrita 02

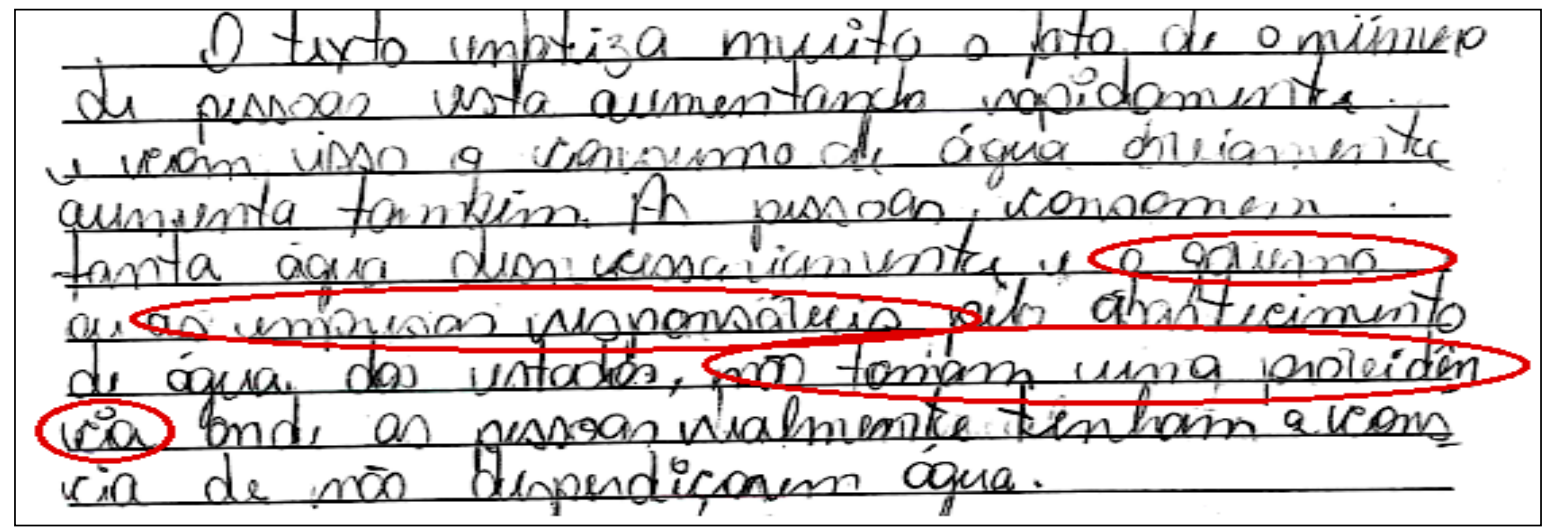

Fonte: textos produzidos pelos colaboradores de pesquisa. 
Na produção da aluna 19, governo e empresas (linhas 05 e 06) assumiram volição ao tomarem providências (linhas 07 e 08) a respeito do abastecimento de água nos estados. Assim, governo e empresas representam, respectivamente, os governantes e os donos das empresas que fornecem água para os estados. Trata-se, portanto, de uma metáfora conceitual na qual uma instituição foi apresentada para representar as pessoas que a compõem.

A Figura 07 retrata, nos trechos em destaque, outro tipo de metáfora de personificação.

Figura 07 - Excerto 02 do texto da aluna 19 sobre a crise hídrica - atividade escrita 02.

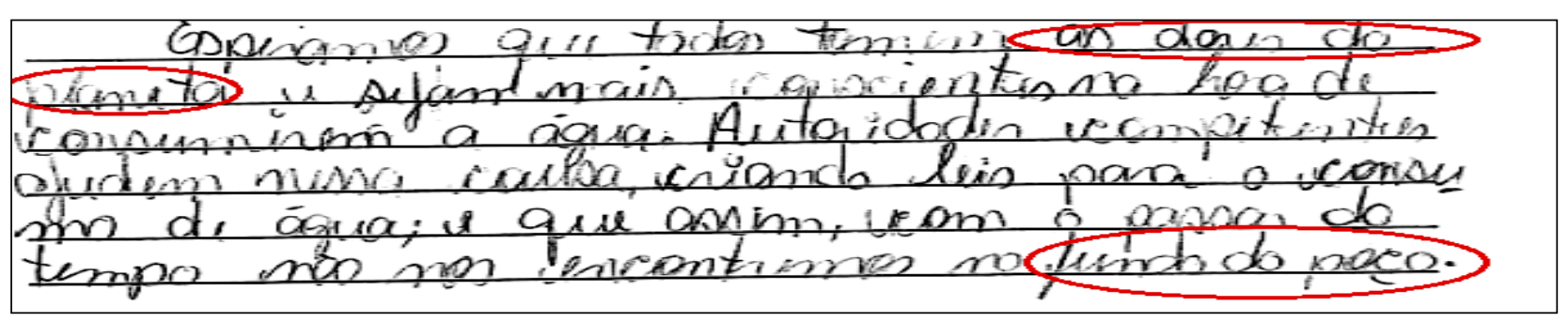

Fonte: textos produzidos pelos colaboradores de pesquisa.

A aluna 19, em outro trecho de seu texto, atribuiu ao planeta (linhas 01 e 02 ) sentidos humanos, como a dor, que representa as mazelas do planeta em decorrência da crise hídrica. Ela finalizou seu texto retomando a metáfora conceitual fundo do poço (linha 06), incluindose como agente de mudança para os problemas da crise hídrica, que levam a sociedade para uma situação crítica, em que a palavra fundo representa expressão espacial quando aliada à poço, uma vez que cria a perspectiva conceitual de depressão, atolamento, refletindo conceito já partilhado durante a primeira discussão desse texto com a turma.

Assim, a teoria que Lakoff \& Johnson ([1986]2012) desenvolvem acerca das metáforas possui relevância conceitual, pois eles analisam os processos cognitivos por meio de expressões cognitivas nas quais é possível expressar conhecimento a partir das experiências que regem o sistema conceitual. Porém, essa teoria não avança para a percepção do processamento discursivo nos vários contextos interacionais nos quais as metáforas são produzidas, uma vez que esses autores consideram somente os processos mentais acionados na construção das metáforas, não analisando que elas são também construídas e processadas no processo de interação social.

Dessa forma, as construções analisadas (Figuras 06 e 07) seriam tratadas unicamente como metáforas conceituais, relacionadas a fenômenos mentais de percepção do espaço, do tempo e da experiência com objetos e substâncias. 


\title{
1.5.2. A narrativa no processo inferencial
}

A narrativa, há muito, vem sendo apresentada por Bruner (1991 e 2004) como modo de organização das experiências e das memórias de acontecimentos humanos. Esse autor (1991, p. 04) entende que

\begin{abstract}
(...) a narrativa é uma forma convencional, transmitida culturalmente e restrita por cada nível de domínio individual e por seu conglomerado de dispositivos protéticos, colegas e mentores. Ao contrário das construções geradas por procedimentos lógicos e científicos que podem ser destruídas por causa de falsificações, construções narrativas só podem alcançar "verossimilhança". (BRUNER, 1991, p. 04)
\end{abstract}

Desse modo, a narrativa constitui não somente uma forma de representar a realidade, mas, acima de tudo, é um modo de construí-la. Por meio da narração de experiências, relatos de fatos e histórias diversas, os alunos constroem conhecimentos quando deparam com questões que os fazem refletir acerca de determinado assunto.

O Excerto 6 e a Figura 8 demonstram as representações da aluna 06 sobre a crise hídrica por meio da narrativa realizada tanto em seu texto escrito como durante o grupo focal, quando faz o mesmo relato feito na atividade 02.

\section{Excerto 06 - Grupo Focal}

01 Aluna 06: Assim... eu compreendi pela minha vivência, né. Tipo o córrego ali ((apontando)) que 02 o pessoal pescava, que tem aquelas pontinhas assim ((fazendo o gesto que representa a ponte)). $\mathrm{E}$ 03 hoje a gente passa lá e não aguenta o mau cheiro. Então, não tem mais peixe, não tem vida. $\mathrm{O}$ rio 04 São Francisco, eu fui criada lá. Passei ali na ponte Três Marias, e eu vi, no meio do rio, eu vi 05 areia. Então, eu fiquei em desespero e eu chorei. Porque realmente foi o fundo do poço. Não tem 06 mais para onde correr. Assim... Talvez a gente tente minimizar pra nós que ainda tamo aqui, se 07 cada um resolvesse fazer a sua parte, ia amenizar ainda pra nós, mas pra nossos filhos. ((faz uma 08 negativa. Como se dissesse: "Para nossos filhos, não")).

A aluna 06 iniciou sua narrativa no tempo presente, voltando-se para o córrego que se encontrava próximo ao local de onde ela falava, pois, ao apontar e utilizar a expressão "ali", construiu dêixis $^{22}$ de lugar, que levou os interagentes a inferirem que o córrego se localizava

${ }^{22}$ Consoante Levinson (2007, p. 65), a dêixis se refere às maneiras pelas quais as línguas codificam ou gramaticalizam os traços do contexto de enunciação ou do evento de fala. Esse termo vem do grego, significando apontar ou indicar, e se manifesta pelo uso dos demonstrativos, dos pronomes de primeira e 
na cidade de São Sebastião - DF. Na linha 04, a estudante se reportou ao período de sua infância ao referir-se ao rio São Francisco e narrou o momento quando retornou à ponte Três Marias e, onde havia rio, ela só enxergou areia. Ela relatou o desespero que sentiu e como chorou. Por isso, usou a expressão "fundo do poço" para retratar como a sociedade se encontrava, sugerindo, ao fim de sua produção, que, com a boa vontade de todos ao fazerem sua parte, a situação iria se amenizar na atualidade e no futuro.

Mais uma vez, essa aluna utilizou a narração como recurso para iniciar o seu texto e reforçar a argumentação que desenvolveu depois. Bruner (2002, p. 140) afirma que a narrativa constitui um modo de pensar, ou seja, um processamento cognitivo que constrói realidades e, nesse contexto de análise, auxiliou a aluna 06 (Figura 08) a desenvolver seu ponto de vista diante do tema nas duas situações em que utilizou a narração.

\section{Figura $08^{23}$ - Texto da aluna 06 sobre a crise hídrica - atividade escrita 02.}

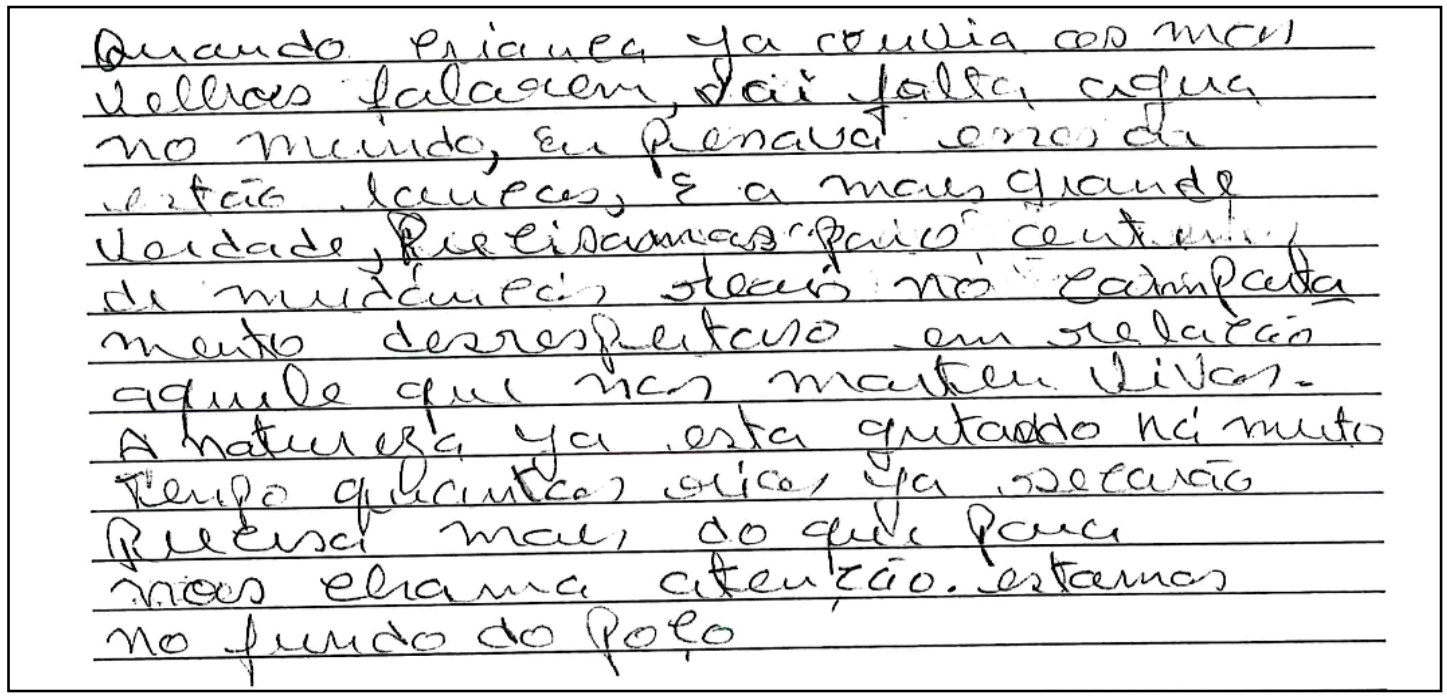

Fonte: textos produzidos pelos colaboradores de pesquisa.

Bruner (2002, p. 12) afirma que existem dois tipos de pensamento que funcionam de formas diferentes no ordenamento das experiências pessoais dos sujeitos e na construção da realidade: o pensamento narrativo e o pensamento lógico-científico.

segunda pessoa, do tempo verbal, dos advérbios de tempo e lugar específicos, além de uma variedade de outros traços gramaticais relacionados diretamente às circunstâncias da enunciação. (Ibid, p. 65)

23 Texto da aluna 06 sobre a crise hídrica (com alguns ajustes relativos à norma padrão):

“Quando criança, já ouvia os mais velhos falarem 'vai faltar água no mundo', eu pensava: 'esses estão loucos'. É a mais grande [sic] verdade. Precisamos (trecho ilegível) de mudanças reais no comportamento desrespeitoso em relação àquele que nos mantêm vivos.

A Natureza já está gritando há muito tempo. Quantos rios já secaram. Precisa mais do que para nos chamar atenção? Estamos no fundo do poço. ” 
Cada uma das maneiras de conhecimento tem princípios operativos próprios e seus próprios critérios de boa formação. (...) Ambos podem ser usados como meio de convencer o outro. Não obstante, do que eles convencem é fundamentalmente diferente: os argumentos convencem alguém de sua veracidade, as histórias de sua semelhança com a vida. O primeiro comprova através de um possível apelo a procedimentos para estabelecer provas formais e empíricas. $\mathrm{O}$ outro estabelece não a verdade, mas a verossimilhança. (Ibid, p. 12)

É visível a presença dos dois tipos de pensamento nos dois dados sob análise. A aluna 06 orientou sua fala por meio da narração, que serviu de base para a construção da argumentação no decorrer de seu texto (figura 08). Bruner (2002 p. 141) argumenta ser a narração um dos meios pelos quais se desenvolve a metacognição. É por meio das narrações que os sujeitos se reconhecem e reconhecem o outro. Então, concorda-se com esse autor quando ele sugere que as narrativas deveriam ter espaço nos ambientes escolares, pois, ao conferir espaço aos alunos para contarem histórias ou narrarem fatos de suas vidas, eles se veem como seres sociais que vivenciam os conteúdos trabalhados em sala e compreendem as abstrações a partir do contato inicial com experiências concretas.

No próximo excerto, a aluna 12 também desenvolveu uma narrativa como estratégia de construção de sua argumentação a respeito da falta de compromisso de uma parcela da população com a economia de água.

\section{Excerto 07 - Aula 05}

01 Aluna 12: Professora, eu trabalhei numa casa, num apartamento no Sudoeste e lá tem duas 02 criança né, aí um dia, todo dia ela ((a patroa)) botava o menino pra tomar banho, aí ligava o 03 chuveiro aí o menino ficava passando ( ) no chuveiro pra tomar banho, aí eu ia lá e desligava , aí 04 ela ia lá fazia a mesma coisa. Aí um dia eu falei pra ela assim "porque você tá gastando tanta 05 água? Tem que economizar água". Sabe o que que ela me disse? Que economizar água era coisa 06 de pobre, eu falei "jura que é coisa de pobre? Pois quando for um dia que tiver faltando essa água 07 que você tá derramando há horas e horas e horas aí você vai sentir falta". Pois ela ligava o 08 chuveiro e ficava passeando pelado dentro de casa ((o filho da patroa)) aí quando ele entrava 09 dentro do chuveiro, ele ficava duas, três horas brincando debaixo do chuveiro com o chuveiro 10 ligado. Eu ia lá e desligava, ela ia lá e ligava e nós ficava brigando, eu e ela.

A narração constitui, assim como a metáfora, um modo de manifestar as experiências pessoais no processo de construção de sentido, funcionando como estratégia de inserção de ponto de vista. A aluna 12 utilizou a narração da experiência profissional com a patroa como modo de se posicionar, diante dos colegas, sobre a importância da economia de água durante o banho. 
A narração é, portanto, estruturadora do ato de pensar. Como Vygotsky ([1934]2001, p. 54) define, o discurso exterior é o ponto de partida para a construção do discurso interior ${ }^{24}$. Conclui-se, assim, que o desenvolvimento do pensamento é determinado pelas atividades linguísticas desenvolvidas em atividades de atenção conjunta.

\subsubsection{O uso de expressões referenciais na construção de inferências}

Koch (2008, p. 112) ressalta a indiscutível importância das expressões nominais nos processos de construção, categorização e recategorização dos objetos do discurso e, por conseguinte, no processo de construção das inferências. Na ausência dessas expressões, seria inviável compreender efetivamente tudo que está explícito e implícito na base referencial dos textos, haja vista que elas são responsáveis por boa parte do tópico discursivo e pela construção argumentativa dos textos, configurando-se, então, base essencial na construção dos sentidos.

Desse modo, leituras e vivências fornecem aos estudantes modelos mentais que são compartilhados entre os interagentes, tornando a atividade de processamento textual colaborativa. Ressalta-se, assim, a importância de atividades de compreensão textual que permitam aos estudantes expressarem seus modelos mentais, ouvirem outras formas de compreensão por meio da interação com outros colegas e construírem sentidos que tornem o processamento textual uma ação sociocognitiva. Assim, as categorizações e recategorizações fazem parte da construção do conhecimento e constituem processo dinâmico e encarnado no contexto social que permeia o texto.

Koch (2008, p. 112) fornece exemplo de categorização e recategorização por meio de expressões nominais anafóricas referentes à Lampião, que o categorizam e, posteriormente, o recategorizam:

Lampião, o mais famoso cangaceiro do Nordeste, é uma figura altamente controvertida. Para uns é um santo, pai dos pobres, grande justiceiro. Já outros o consideram um verdadeiro demônio, um gênio de maldade, violento e cruel. De qualquer maneira, ele é um dos mais importantes vultos da história dessa região de nosso país (realces da autora).

As crenças sociais determinam como categorizar/recategorizar o mundo. São as referenciações que denominam os objetos do discurso e elas se relacionam diretamente com as questões ideológicas que os permeiam. Por isso, existem crenças que produzem expressões

\footnotetext{
${ }^{24}$ Os detalhes a respeito de discurso interior e discurso exterior serão apresentados no capítulo 02.
} 
nominais que caracterizam Lampião de forma positiva e outras que o veem de modo negativo, relacionando-o a um ser violento. Ao final do parágrafo, o cangaceiro é recategorizado como um dos mais importantes vultos da região Nordeste - sem inserir valoração negativa a essa personalidade.

Cabe uma investigação, conforme entende Marcuschi (2007a, p. 125), cuja preocupação não seja o modo como se organiza a ordem dos conhecimentos, se eles já estão no mundo ou se são produzidos na mente dos sujeitos. Importa, conforme esse autor, como a ordem é percebida, construída, comunicada e utilizada, pois a ordem que fundamenta a construção do conhecimento não é essencialmente mundana, é uma ordem cognitiva e interativamente semiotizada: uma ordem histórica e sociointerativa.

Dessa maneira, é necessário que os olhares das pesquisas a respeito da referenciação considerem a natureza sociocognitiva dos seres humanos para superar a concepção essencialista do conhecimento, segundo a qual ele é fixo e necessita ser apreendido. O conhecimento é, nesses termos, reflexivo e dinâmico.

Dizer que Lampião é um herói ou um ladrão poderia ser visto, pela Semântica formalista, como duas hipóteses que precisariam passar por julgamentos de vericondicionalidade, para, assim, a partir da comparação com condições de mais verdade ou menos verdade, chegar-se a uma conclusão. Mas tal conclusão não considera as crenças sociais que fazem alguém caracterizar Lampião como um herói ou como um ladrão. Sobre isso, Marcuschi (2007a, p. 126) afirma que

\begin{abstract}
o problema está muito mais na natureza do dito e na natureza do acesso ao mundo, que na natureza da coisa em si mesma. Aqui nada é óbvio e o papel da linguagem na cognição é imenso. Não se pode escamoteá-lo e tratar a verdade como uma questão de correspondência entre o enunciado e o fato (...) É pouco iluminador dizer que 'é verdade' equivale a 'corresponde aos fatos' (destaques do autor), pois toma os fatos como se fossem dados naturalmente e como se a linguagem tivesse a propriedade de dizê-los naturalmente (...) Esse caminho (...) revela-se profundamente desanimador nos dias atuais. (Ibid, p. 126)
\end{abstract}

Mondada \& Dubois (2003, p. 20) afirmam que existe intersubjetividade nas negociações, nas modificações e nas ratificações de concepções individuais e públicas de mundo. Com essa base, pode-se afirmar que a objetividade tem em sua fonte a intersubjetividade. As pessoas concordam subjetivamente porque classificam e organizam o mundo de forma parecida quando vivem na mesma cultura (MARCUSCHI, 2007a, p. 131). A categorização surge, assim, a partir de uma relação de coerência das crenças entre dois sujeitos e o mundo, e não no contato direto da mente com o mundo. Isso pressupõe conceber 
que a mente do sujeito não funciona individualmente, mas interligada a outras mentes de modo situado e encorpado. (Ibid, p. 134)

As categorias sempre foram tratadas como representação do mundo. Todavia, Marcuschi (2007a, p. 136) sugere evitar tomar as referências como representações mentais fixas. Foge-se, aqui, da visão monológica de língua, com vistas a defini-la como forma de ação interativa, social, cognitiva e situada. As categorias estão, portanto, ligadas às culturas e constituem sistemas de cognição e não contextos inertes.

\begin{abstract}
As categorias constituem-se no processo intersubjetivo de pelo menos duas mentes convergindo sobre a melhor forma de construir uma dada proposição diante do mundo. E nisto surge uma relação de coerência de duas posições sobre um dado fenômeno. Em outros termos, a produção de categorias seria uma atividade sóciocognitiva (sic) situada em contextos culturais específicos na tentativa de construir o conhecimento. (MARCUSCHI, 2007a, p. 136)
\end{abstract}

Portanto, em se tratando da categorização, não se pode pensar numa teoria de correspondência entre entidades mentais e entidades do mundo, mas na teoria da coerência. Nela, a intersubjetividade dos objetos de discurso dialoga com outras intersubjetividades a ponto de constituir um consenso com categoria(s) e estabilizar o sentido de uma expressão nominal. A tendência é sempre a da cooperação, do diálogo e do comum acordo entre os interagentes. (TOMASELLO, 2009)

A instabilidade e a mudança constituem a dimensão intrínseca do discurso e da cognição. Ao reconhecer o objeto de onde cai água e que é utilizado para o banho em nossa cultura, a professora-pesquisadora o nomeou de chuveiro (vide Excerto 02). Isso não significou apenas uma nomeação ou identificação de um objeto, mas constituiu a experiência de reconhecimento com base num conjunto de condições estabilizadas numa dada cultura (MARCUSCHI, 2007a, pp. 139-140). O discurso, por assim dizer, é o lugar privilegiado de designação do mundo. Tal propriedade permitiu que a professora dialogasse com a aluna acerca das categorias possíveis para chuveiro, que não representava, para a aluna, uma ducha da qual saía uma quantidade abundante de água, mas um objeto que, como o da casa dela, não seria capaz de encher vários baldes de água num intervalo de cinco minutos. O saber sobre o mundo é, portanto, uma fabricação socialmente elaborada, por meio de atividades coletivas, e comunicada linguisticamente. O mundo comunicado é sempre fruto de um agir comunicativo ou de uma ação discursiva e não de uma identificação de realidades discretas, objetivas e estáveis. (Ibid, p. 140) 
Os sujeitos não são apenas enunciativos, mas atores sociais que instauram e dizem o mundo. Assim, as categorizações (descrições, conforme Marcuschi) são reflexivas (elaboram as circunstâncias de sua aparição), indexicais (existem no contexto em que são fabricadas) e situadas (invocadas e fabricadas para fins práticos). (Ibid, p. 141)

Passa-se, então, ao questionamento: como se dá a cognição na interação social? — no lugar de: que tipo de relação é a cognição? (MARCUSCHI, 2007a, p. 143). Compreender o que alguém diz num determinado momento é, antes de tudo, compreender o contexto de sua enunciação. A indeterminação da linguagem só pode ser desvendada se os interagentes negociarem os sentidos para o contexto em torno do qual os objetos de discurso foram lançados. A mente humana não categoriza e recategoriza por si própria. Trata-se de processo que ocorre nas práticas sociais, sendo, portanto, interacional e cognitivo.

Por esse motivo, nesta subseção, o termo a ser utilizado para se referir às categorizações e às recategorizações realizadas pelos colaboradores de pesquisa será expressões referenciais, uma vez que elas foram construídas por meio das interações sociais estabelecidas dentro e fora do contexto escolar e não se restringem a nominalizações encapsuladas. São, portanto, expressões que indicam os conhecimentos construídos e reconstruídos a respeito da temática refletida em sala de aula.

Assim, a expressão popular irá se referir à cidade de São Paulo e fundo do poço, à situação catastrófica pela qual a cidade estava passando, conforme se pode constatar na figura seguinte.

Figura $09^{25}$ - Texto da aluna 13 sobre a crise hídrica - atividade escrita 02.

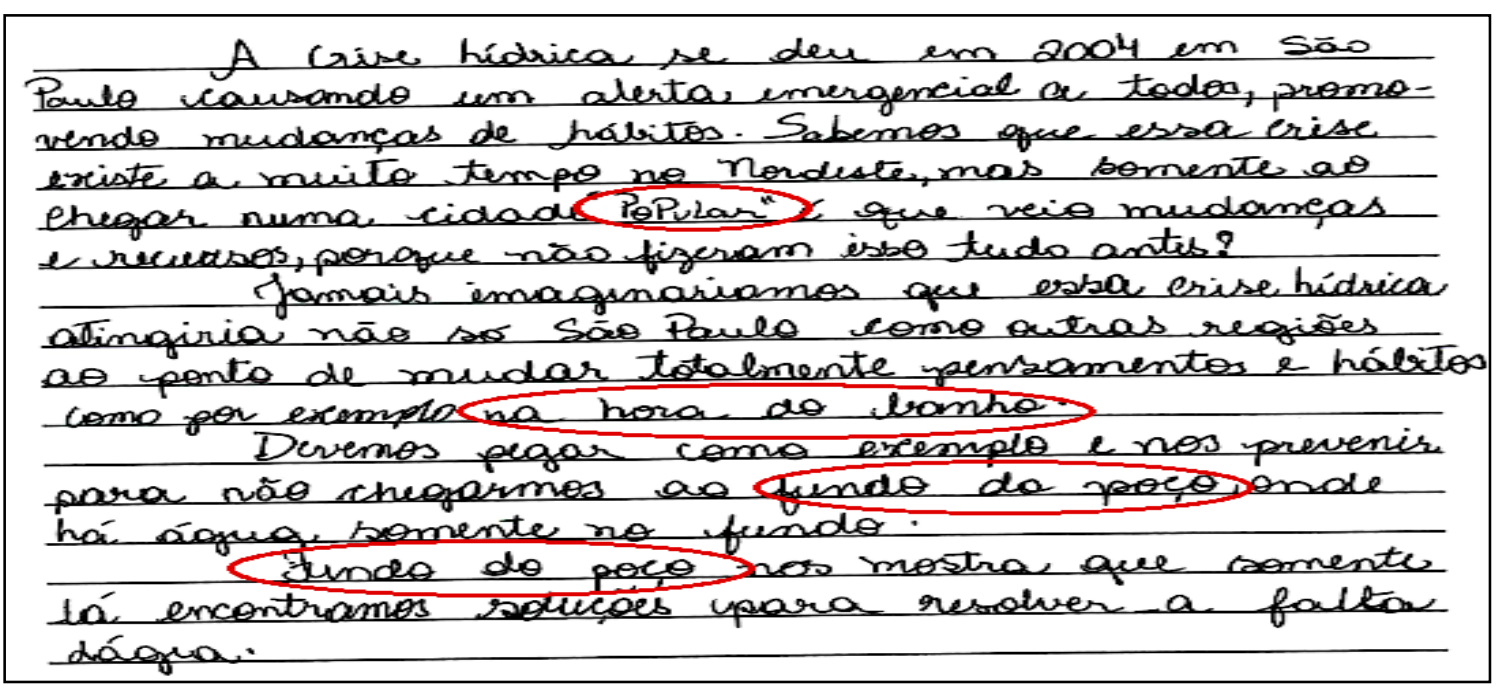

${ }^{25}$ Após as discussões e as incursões sobre o tema "Crise hídrica" por meio dos gêneros textuais apresentados aos alunos, a última atividade versava sobre o texto "O fundo do poço" (anexo II). Ao final das discussões realizadas nas aulas, cada aluno teria que escrever um ou mais parágrafos se posicionando diante do tema. 
Os termos utilizados pela aluna 13 (Figura 09) indicam o modo como ela foi construindo sentidos a partir da leitura do texto $O$ fundo do Poço (anexo II). Primeiramente, ela utilizou a expressão popular (linha 05) para designar a cidade de São Paulo — local que fez com que a crise a hídrica ganhasse atenção nacional - fato bastante comentado durante as discussões coletivas. Alguns alunos relataram que a seca na região Nordeste já acontecia há muitos anos, mas foi preciso que a falta de água alcançasse a cidade de São Paulo para a crise ser reconhecida e para mudanças serem sugeridas pela sociedade. No Excerto 08, a aluna 10 dialogou com a professora a respeito desse tema, no curso da primeira aula:

\section{Excerto 08 - Aula 01}

01 Aluna 10: Professora, deixa eu te fazer uma pergunta: o Nordeste, o Nordeste sempre sofreu com 02 falta de água ( ) e foi muito falado não é de agora. Será por que que agora a crise de água ficou 03 esse alarde todo porque São Paulo tá faltando água? Por que não procuraram uma solução há 04 anos, há trinta anos, quarenta anos atrás (desde) que o Nordeste tava sofrendo com essa seca?

05 Professora: Se a gente for pensar no tamanho do Nordeste pro tamanho do estado de São Paulo, 06 não é nada.

O diálogo estabelecido entre a aluna 10 e a professora ampliou a percepção da turma diante da situação da falta de água no Estado de São Paulo. A aluna 13 demonstrou isso no momento em que designou São Paulo como uma cidade "popular" (linha 05) - aquela que mais aparece na mídia. O mesmo aconteceu no final do segundo parágrafo por meio da expressão "na hora do banho" (linha 10), em que a estudante retomou a discussão estabelecida no trecho da aula 04, exposto no Excerto 01. Nessa aula, aconteceu a discussão sobre as maneiras de economizar água, que teve como texto motivador o boletim informativo da rádio Nova Brasil FM (texto 01).

A aluna 13 categorizou a cidade de São Paulo como popular por meio da ativação de referentes. Koch (2014, p. 51), inspirada em Prince (1981, p. 236), caracteriza esse tipo de ativação como ancorada, pois um objeto de discurso novo foi inserido no texto. Quando um objeto de discurso novo apenas é reativado por algum tipo de associação com elementos presentes no cotexto ou no contexto sociocognitivo passível de ser estabelecida por associação elou inferenciação, trata-se de ativação ancorada, que também pode ser vista na expressão fundo do poço (linhas 12 e 14), que está associada ao título da reportagem lida e discutida pela professora-pesquisadora e os estudantes antes dessa produção escrita. 
A rotulação poderá ser mantida ou reconstruída. A reconstrução é a operação responsável pela manutenção em foco, no modelo do discurso, de objetos previamente introduzidos dando origem a cadeias referenciais ou coesivas (KOCH, 2014, p. 53). Esse processo muito contribui para a progressão referencial do texto, pois opera a recategorização dos objetos de discurso, ou seja, esses objetos serão reconstruídos de determinada forma, consoante o modo de dizer do enunciador. (Ibid, p. 53)

No texto da aluna 16 (Figura 10), é evidente a utilização de expressões referenciais já utilizadas em outros momentos da discussão, as quais auxiliaram na ativação de conhecimentos.

Figura 10 - Texto da aluna 16 sobre a crise hídrica - atividade escrita 02.

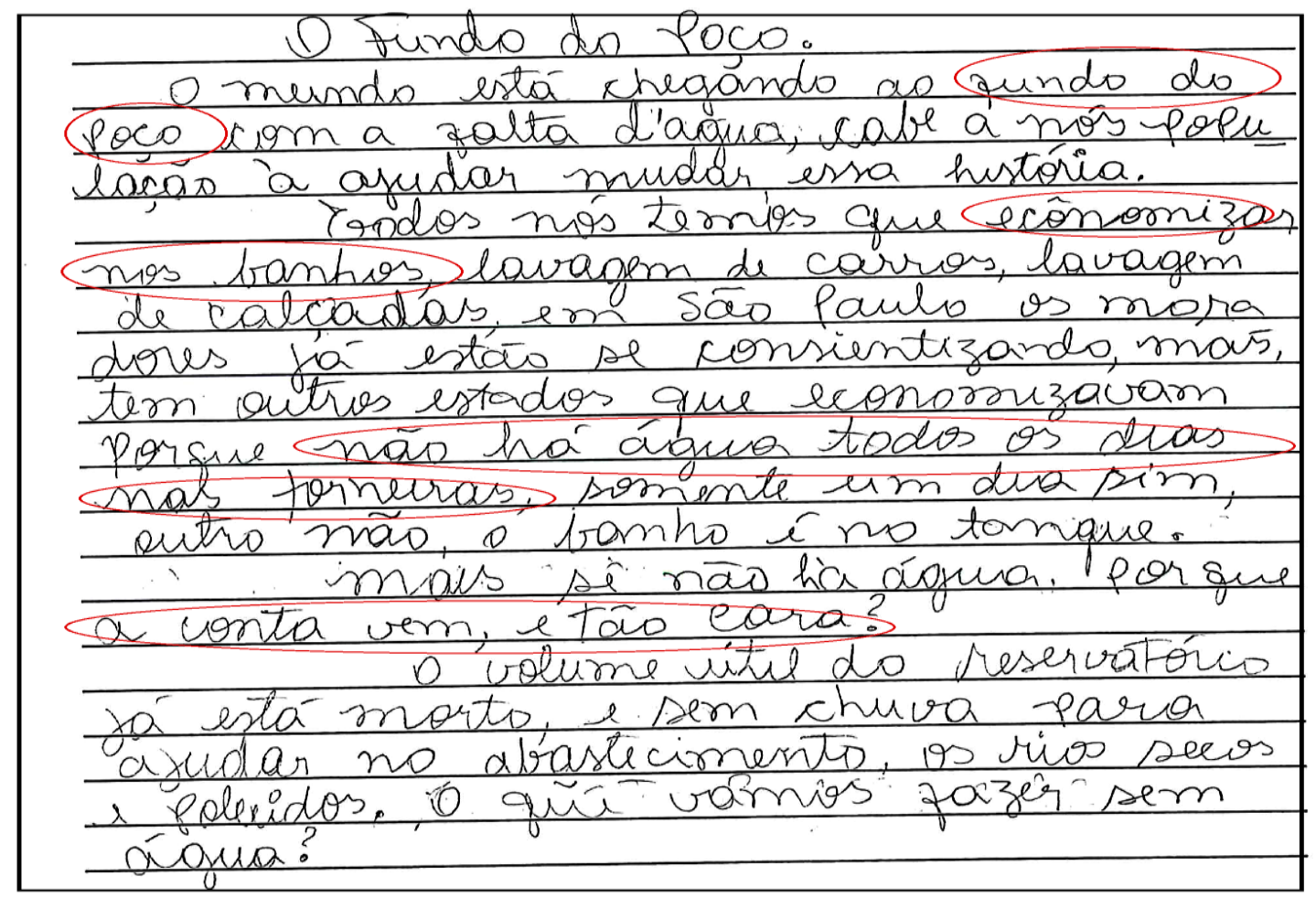

.Fonte: textos produzidos pelos colaboradores de pesquisa.

No primeiro parágrafo, a expressão fundo do poço (linhas 02 e 03) apareceu novamente com a ideia de negatividade, de estar por baixo, como discutido pela professorapesquisadora e os alunos, no Excerto 05 (p.48). Além disso, a aluna 16 relacionou essa situação à falta de água. Já no segundo parágrafo, ela retomou a ideia da economia de água no banho (linhas 05 e 06), outro tópico discursivo bem explorado com a turma por meio do texto 01 (boletim informativo da rádio Nova Brasil FM). 
Ao final do segundo parágrafo e no início do terceiro (linhas 10, 11 e 14), a aluna 16 afirma que não há água todos os dias nas torneiras, mas, mesmo assim, a conta vem, e tão cara. Essas expressões que, de modo superficial, parecem uma nova informação introduzida secundariamente constituem, na verdade, a retomada da discussão estabelecida por meio do texto 03 , presente na primeira atividade escrita.

\section{Texto 03 - Charge}

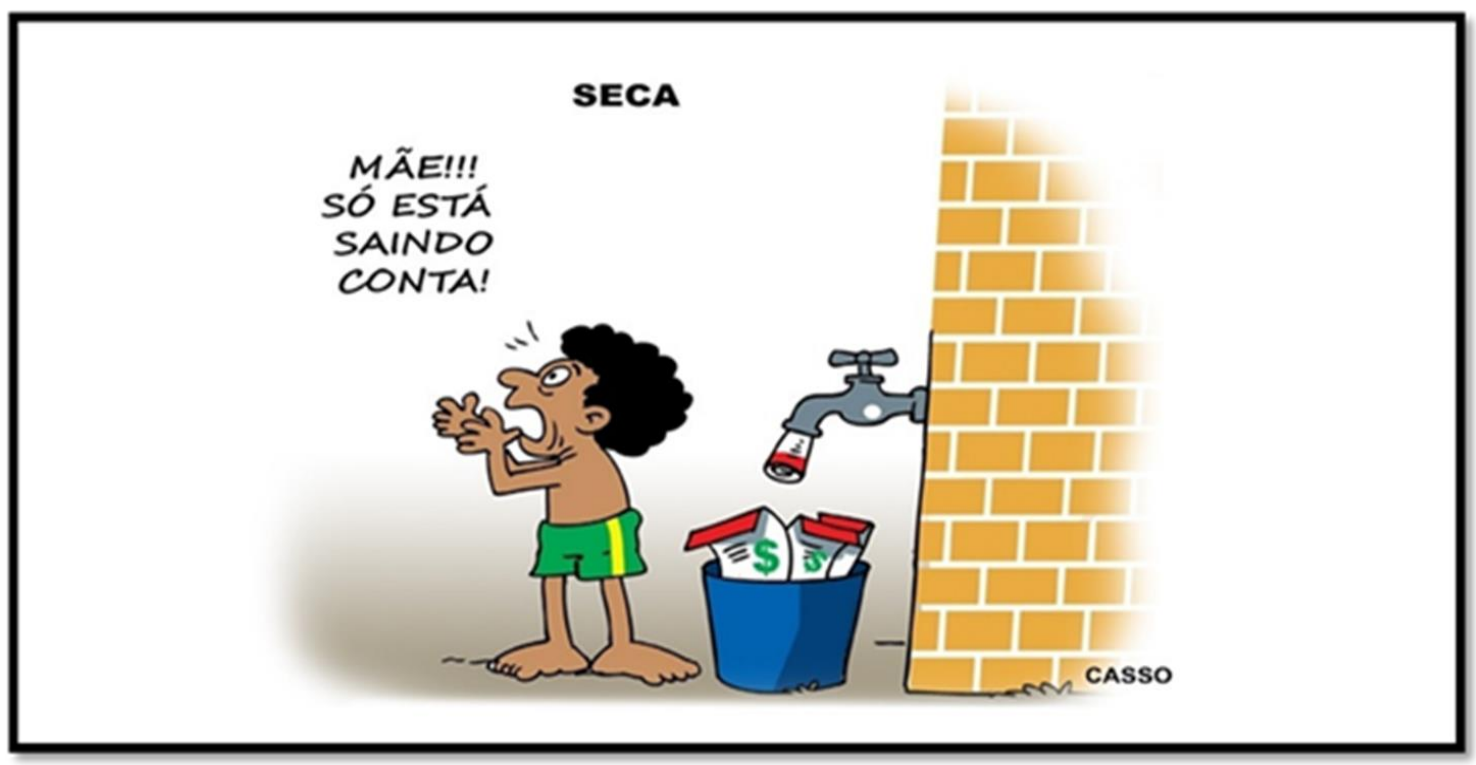

Fonte: http://imguol.com/c/noticias/2014/11/10/11nov2014---o-chargista-casso-ironiza-a-falta-de-agua-queatinge-o-estado-de-sao-paulo-1415645435788 956x500.jpg. Acesso em 13/03/2015

A referenciação constitui atividade discursiva $(\mathrm{KOCH}, 2014$, p. 48). Os sujeitos, durante a produção escrita ou na interação verbal, operam com o material linguístico que têm à sua disposição e fazem escolhas que sejam significativas, com a finalidade de se expressarem por meio desses recursos linguísticos.

Dessa forma, é possível inserir objetos de discurso mantendo, modificando ou expandindo-os, de modo que, durante o processo de compreensão, desdobra-se uma unidade de representação externamente complexa, em virtude do acréscimo sucessivo e intermitente de novas categorizações (recategorizações) elou avaliações do referente. (Ibid, p. 49)

Essa mesma aluna compreendeu o texto 03 da seguinte maneira (Figura 11): 
Figura 11 - Texto da aluna 16 sobre o texto 03 - atividade escrita 01.

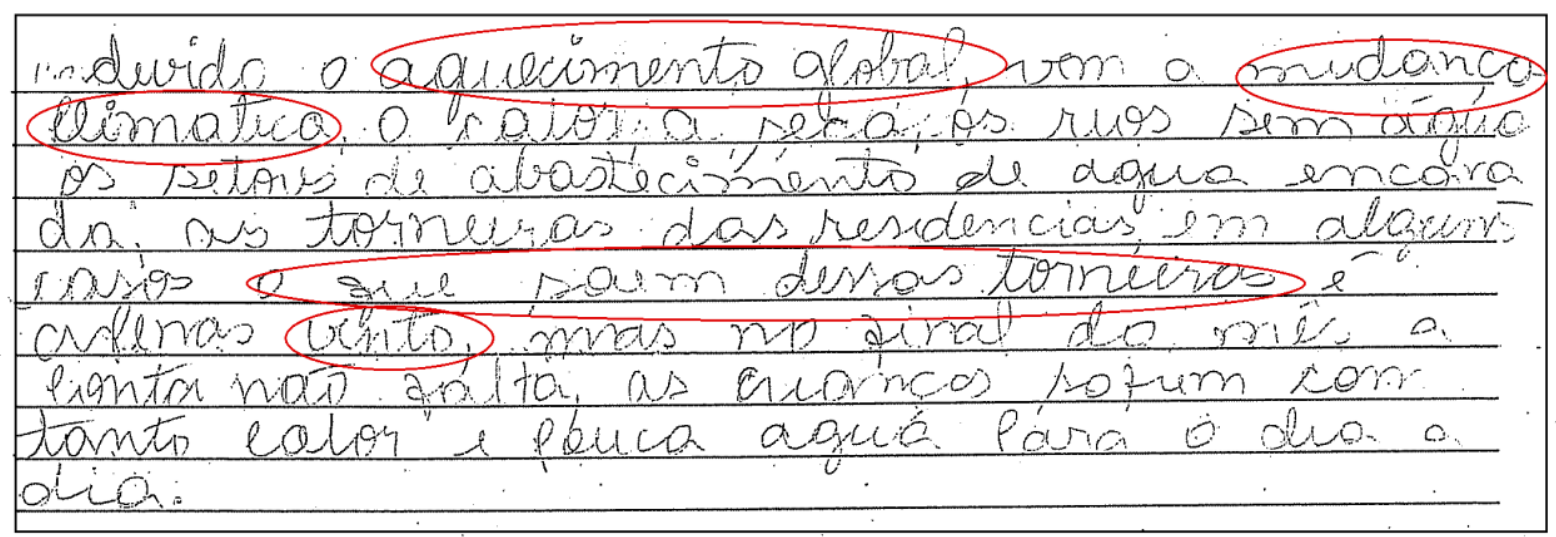

Fonte: textos produzidos pelos colaboradores de pesquisa.

Do mesmo modo como a aluna 16 resgatou as informações contidas no texto 03 , no parágrafo que construiu a respeito dessa charge, ela retomou expressões como aquecimento global (linha 01), mudanças climáticas (linhas 01 e 02) — temas que foram abordados pela professora regente da turma em vídeo selecionado por esta e pela pesquisadora em aulas anteriores.

A expressão o que sai das torneiras é vento (linhas 05 e 06), mas a conta de água chega todo mês, foi retomada por essa aluna na atividade 02 (Figura 10) no final do segundo parágrafo e no início do terceiro (não há água todos os dias nas torneiras e a conta vem, e tão cara). Desse modo, entende-se que a realidade é construída, mantida e alterada não somente pela forma com que os sujeitos nomeiam o mundo, mas, acima de tudo, pela forma como eles interagem sociocognitivamente com ele.

Os alunos interpretam e constroem suas realidades por meio da interação entre suas vivências e os diversos textos orais e escritos disponibilizados a eles, que os levam a categorizarem e recategorizarem de acordo com as experiências vividas física, social e culturalmente, por meio da construção de objetos de discurso.

$\mathrm{O}$ emprego de formas nominais para designarem objetos de discurso legitima o diálogo do sujeito enunciador consigo mesmo e com os outros e desempenha papel importante na orientação argumentativa do texto (CORTEZ \& KOCH, 2013, pp. 09-10). Para as autoras (ibid), isso significa que os objetos do discurso revelam o modo subjetivo pelo qual o enunciador manifesta seu ponto de vista.

Os sujeitos dão sentido às suas experiências e representações, à sua identidade e à sua posição, por meio da qual se constituem e se afirmam no interior das práticas simbólicas (...). Por esta razão, o ponto de vista (PDV) não se limita à expressão de 
uma percepção e integra julgamentos e conhecimentos que o locutor e/ou enunciador projetam sobre o referente. (CORTEZ \& KOCH, 2013, p. 10).

As formas nominais que corroboram para a progressão referencial do texto são, assim, expressões predicativas que expressam o ponto de vista do enunciador como modo de externar suas representações construídas na alteridade e na sua relação com o mundo. Cortez \& Koch (2013, p. 11) denominam as formas de expressão do ponto de vista, por meio da referenciação, como dialogismos que podem se manifestar do enunciador em relação a si mesmo (autodialogismo) e do enunciador em relação aos outros (heterodialogismo).

Os dados apresentados, até o momento, indicam que os pontos de vista expressos pelos alunos revelam autodialogismo quando eles relatam vivências próprias para contrapôlos com as discussões estabelecidas em determinados contextos, mas, na maioria das vezes, o ponto de vista é construído no diálogo com os outros (heterodialogismo).

Logo, fica evidente que as expressões referenciais em destaque utilizadas pelos alunos em suas produções textuais (Figuras 08, 09 e $10-$ p. 55, 60 e 62, respectivamente) foram construídas, em sua maioria, por meio das interações promovidas e mediadas pela professorapesquisadora. Quando a aluna 13 empregou a expressão popular para designar o estado de São Paulo, ficou evidente sua alteridade ao expressar esse juízo de valor. Porém, vê-se que parte desse ponto de vista foi construído por meio das interações verbais ocorridas em sala de aula, o que caracteriza esse ponto de vista como heterodialógico.

Possuem também características do heterodialogismo, as formas nominais fundo do poço, utilizadas pelas alunas 13 e 16 para relacionarem essa expressão com o título da matéria jornalística lida e discutida em sala. As alunas mesclaram as diferentes formas de compreender a expressão, ora como aquele fundo do poço que possui água; ora como o fundo poço, estado emocional que indica uma situação crítica. Ambas as compreensões foram debatidas durante a aula 04 e, por esse motivo, representaram construção coletiva dos objetos de discurso.

A mesma caraterística de heterodialogismo está presente nas expressões a conta vem, e tão cara, aquecimento global, mudanças climáticas e o que saem [sic] dessas torneiras é apenas vento. Todas partiram do diálogo entre as enunciadoras e os textos com os quais estabeleceram contato anteriormente, ou no exato momento em que estabeleceram contato com os textos que nortearam a produção escrita dessas alunas.

Nas expressões referenciais na hora do banho, economizar nos banhos e não há água todos os dias, há uma mescla de auto e heterodialogismo, pois as alunas 13 e 16 (Figuras 08 - 
p. 55 e 09 - p. 60 , respectivamente) relataram experiências próprias de constante falta de água na cidade de São Sebastião, ratificadas pelas falas dos demais colegas durante os diálogos nas aulas, como se observou na participação da aluna 15 durante o debate sobre o texto 03, ocorrido na terceira aula.

\section{Excerto 09 - Aula 03}

01 Aluna 15: porque mesmo que falte a água, professora, no fim do mês você vai pagar sempre 02 alguma coisa, mesmo que você vá lá e diga: "não, não veio, não tinha a água de jeito nenhum", 03 como aconteceu na minha casa, e mais a conta chegava com taxas e mais taxas que só eles sabem.

O Excerto 09 representou apenas um dos vários relatos reproduzidos pelos alunos, o que fez a turma perceber a situação discutida pela charge como problema que pode atingir outros locais além do estado de São Paulo. Portanto, ao mesmo tempo em que as expressões referenciais foram utilizadas para expressarem pontos de vista pessoais, também expressaram construções coletivas de pensamento acerca do assunto da falta de água.

Por essa razão, é impossível estabelecer o limite em que finaliza a alteridade e começa o pensamento coletivo. Ao contrário, o que foi analisado indica que as expressões referenciais possuem uma orientação argumentativa dos referentes do discurso que passam por um jogo afirmativo de identidades e posições (CORTEZ \& KOCH, 2013, p. 13). Os interagentes incorporam, por meio do ponto de vista expresso por eles, a relação de concordância ou discordância que eles estabelecem entre o texto e si mesmos, assim como entre si mesmos e os outros.

Por conseguinte, os processos de categorização e recategorização com o uso das formas nominais passam pelo processo de construção de pontos de vista que ocorre de modo individual e social. Ou seja, na junção dessas duas perspectivas, que constituem uma linha bastante tênue, em que a alteridade não é construída sozinha, mas por meio da interação com os outros. Por isso, as análises realizadas apenas indicam a dinamicidade do processo de denominação dos objetos do discurso por intermédio das expressões referenciais escolhidas pelos interagentes. 


\subsubsection{As Inferências Conversacionais}

Esta subseção apresenta e discute as inferências conversacionais ${ }^{26}$ elaboradas e reelaboradas pelos colaboradores de pesquisa com vistas a analisar os principais mecanismos inferenciais que constituíram o processo de compreensão textual e que compuseram o corpus desta pesquisa. Serão apresentados alguns exemplos das interações realizadas em sala de aula cuja temática sempre envolverá os textos lidos pela turma sobre a crise hídrica.

A inferência conversacional é, para Gumperz (1982a, p. 153), o processo de interpretação situado ou vinculado ao contexto, por meio do qual os participantes avaliam as intenções dos outros, e com base no qual baseiam suas respostas ${ }^{27}$. Assim, os conhecimentos que os sujeitos já possuem, as relações que estabelecem com os outros e as pressuposições socioculturais, aliadas ao conteúdo da enunciação, constituem fatores que auxiliam na construção das inferências em interações face a face.

Por essa razão, serão analisados trechos das interações realizadas em sala de aula que demonstram como os conhecimentos de mundo dos estudantes, oriundos do contexto sociocultural em que estão imersos, afetam potencialmente a interpretação dos textos. Desse modo, os processos inferenciais também são compostos pela convergência entre os conhecimentos socioculturais e as negociações estabelecidas durante as trocas verbais.

A aluna 01, durante a discussão sobre o texto 04, na aula 03, apresentou ao grupo uma informação sobre a economia de água em outros países.

\section{Texto 04 - Charge}

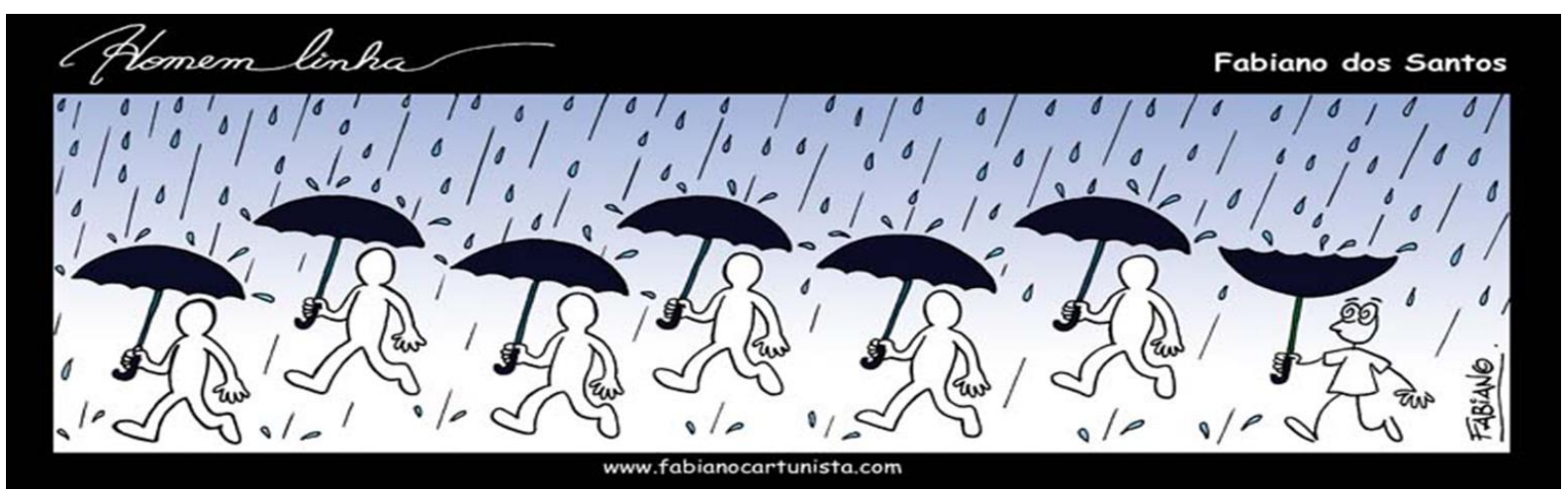

Fonte: https://cantinholiterariososriosdobrasil.files.wordpress.com/2012/08/fabiano-08-2012.jpg. Acesso em $13 / 03 / 2015$

\footnotetext{
${ }^{26}$ Os conceitos de inferência, em aspectos gerais, já foram apresentados no item 1.3. Esta subseção se ocupa em discutir apenas as inferências conversacionais como um dos processos de construção de inferências realizados pelos colaboradores e analisados no item 1.5.

27 Tradução própria.
} 


\section{Excerto 10 - Aula 03}

01 Aluna 01: Professora, nos Estados Unidos, não sei se eles estão passando por essa crise, mas eu 02 só sei que a água lá é caríssima e eles economizam porque eles sentem no bolso.

03 Professora: Os Estados Unidos, os demais países da Europa já têm essa consciência porque eles 04 já começaram a sofrer muito antes de nós. /.../

05 /.../

A aluna 01 ativou o conhecimento de mundo que possuía e o relacionou ao conteúdo do texto 04 , cujo tema consistia em despertar a consciência para o aproveitamento da água da chuva e, consequentemente, para a economia em relação aos recursos hídricos. Esse comentário da aluna aconteceu após um longo período de debate entre a professorapesquisadora e a turma. Naquele momento, os alunos expuseram suas impressões diante do texto, que havia sido lido e interpretado na atividade de compreensão textual escrita aplicada na aula anterior ${ }^{28}$.

Após a participação da aluna 01, a professora-pesquisadora avançou a discussão, e o texto 05 começou a ser debatido.

\section{Texto 05 - Tirinha}

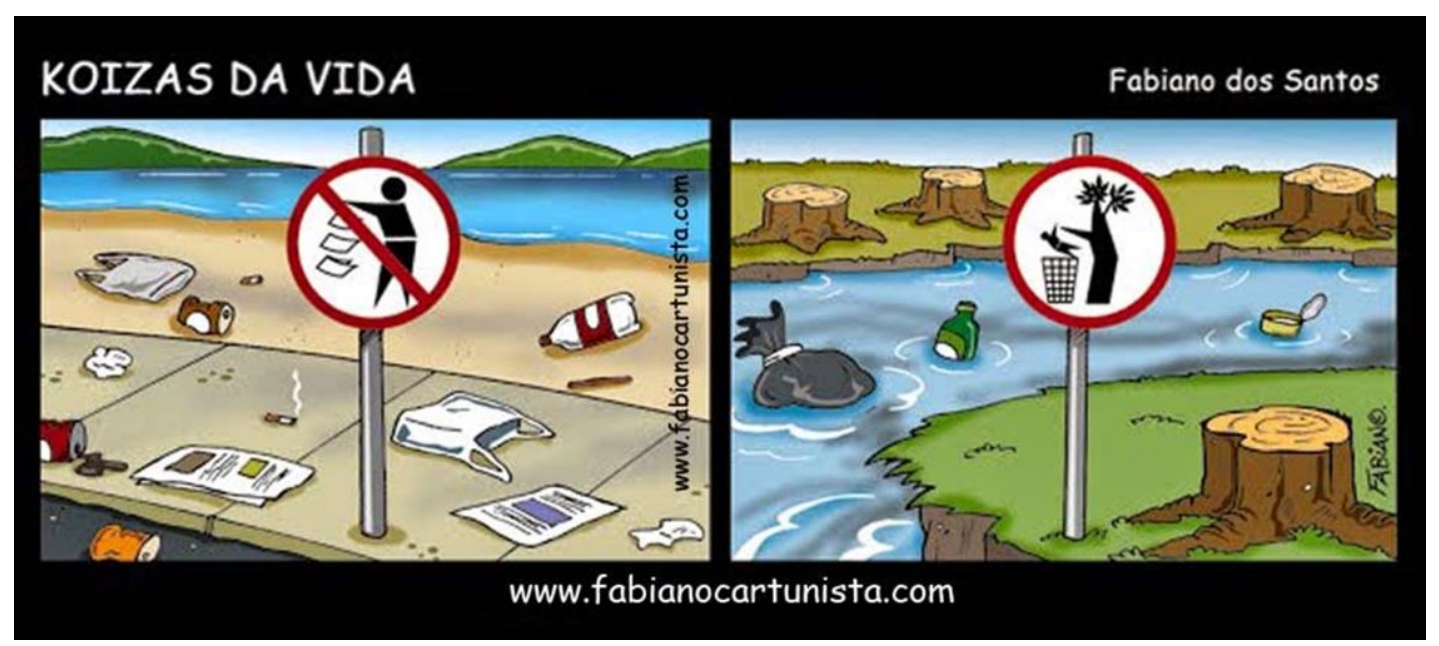

Disponível em: www.fabianocartunista.com. Acesso em 13/03/2015

\section{Excerto 11 - Aula 03}

01 Professora: Aqui num primeiro momento foi só jogar lixo no chão, no segundo ainda tem mais, 02 ainda tem o desmatamento, aí já entra em outros assuntos que a gente discutiu na primeira aula é,

03 e aí nós temos uma outra placa, agora mudou a placa, não mudou?

04 Alunos: Mudou. ((alguns alunos falam a mesma coisa))

05 Professora: E aí o quê essa placa diz?

06 Aluna 01: Que a natureza não aguenta mais.

${ }^{28}$ Os textos produzidos pelos alunos nessa atividade também compõem o corpus desta pesquisa e serão analisados ao longo do trabalho. 
07 Professora: A natureza não aguenta mais a atitude do ser humano, o que ela faz?

08 Aluna 02: Uma atitude.

((vários alunos respondendo))

09 Professora: Ela reage... E aí o que ela faz, qual a reação dela?

10 Aluna 03: Joga ele no lixo.

11 Professora: Joga o ser humano no lixo. É... E aí jogar no lixo a gente pode entender não no

12 sentido mesmo de pegar uma pessoa e colocar a pessoa no lixo, mas no sentido que...

13 Aluna 04: As doenças, né.

14 Professora: Isso. As pessoas estão se contaminando e as pessoas estão sofrendo as consequências

15 do mal que o próprio homem causou... E aí é por isso que nós temos esse título "Coisas da vida".

16 A vida é assim. Nós sabemos disso, que a vida é assim.

17 Aluna 02: Se eu fosse fazer uma leitura, eu diria que realmente o ser humano é o lixo.

18 Professora: /.../ é... podemos fazer, mas vamos, não vamos dizer assim o ser humano, mas

19 alguns, talvez a maioria é das pessoas que não têm consciência /.../. Quantas vezes eu estou

20 dirigindo e aí eu vejo pessoas jogarem latinhas, jogarem papel, e coco, é... Várias e várias coisas

21 que podem inclusive causar um acidente/.../

22 Aluna 02: É, mas é igual eu falo, professora, o pouco é muito né e o muito é pouco, vamo pensar

23 assim, se você joga o coco lá no mato, ele vai se decompor, mas um papel de balinha ele não vai.

No excerto 11 ficou evidente como os sentidos foram sendo construídos ao longo da interação e como a realização das inferências conversacionais colaborou para que os alunos ampliassem a compreensão do texto e partilhassem, entre si, as inferências realizadas na aula anterior, quando eles leram o texto 05 e escreveram um parágrafo sobre ele.

As inferências conversacionais são realizadas por meio dos processos de sinalização compartilhados socialmente, sendo eles constituídos pelas regras gramaticais e lexicais e pelos sinais indexicais compartilhados (pistas de contextualização). Há, desse modo, a interseção entre signo linguístico e contexto estabelecidos ou transmitidos através da experiência comunicativa anterior. (GUMPERZ, 2003, p. 08) ${ }^{29}$

Assim, o texto 05, mesmo não possuindo linguagem verbal, despertou nos estudantes, no momento da primeira leitura, reflexões que foram expressas no(s) parágrafo(s) produzido(s) por eles e analisados pela professora-pesquisadora. Todavia, essas reflexões puderam ser ampliadas durante a interação em sala de aula representada no excerto 11. Nele, a professora-pesquisadora (linhas 03 e 05) propôs aos alunos a transposição de linguagem não verbal para verbal quando solicitou a eles que expressassem o que a placa informava. A partir disso, as alunas 01, 02, 03 e 04 realizaram inferências que foram, cada vez mais, ampliando o conteúdo do debate.

A aluna 01 (linha 06) sugeriu que a natureza não aguenta mais. A professora concordou e acrescentou mais uma informação: a natureza não aguenta mais a atitude do ser humano e lançou outra pergunta a fim de instigar a ampliação das inferências (linha 07). A

\footnotetext{
${ }^{29}$ GUMPERZ, J. Entrevista a Carlo Prevignano.
} 
aluna 02 respondeu à professora, junto a vários outros colegas que não tiveram suas falas registradas devido à grande sobreposição de vozes. Na linha 09, a professora fez uma paráfrase do que havia sido dito pela aluna 02 e utilizou, mais uma vez, estratégia de ampliação das inferências, ao passo que a aluna 03 (linha 10) abordou a reação da natureza diante das mazelas do homem.

$\mathrm{Na}$ linha 11, a professora-pesquisadora disse que a natureza jogava o homem no lixo e instigou os alunos a refletirem sobre o significado dessa ação expressa na charge. A aluna 04 sugeriu ser a geração de doenças uma das consequências da falta de zelo do homem, e a professora-pesquisadora acolheu essa opinião, ampliando o assunto e fazendo com que a aluna 02 revelasse, na linha 17, que se fosse fazer uma leitura, ou seja, se pudesse realizar a atividade escrita novamente, poderia realmente afirmar que o ser humano é um lixo. Isso revela como as inferências realizadas no curso da interação face a face ampliam a compreensão textual dos alunos. Além disso, indicou que as inferências conversacionais foram realizadas por meio da interação entre o conteúdo pragmático expresso no texto não verbal com as pistas de contextualização oferecidas pela professora-pesquisadora e acolhidas pelos alunos. Finalmente, na linha 22, após os exemplos concretos fornecidos pela professora (linhas 18-21), a aluna 02 compartilhou com a turma o conhecimento que já possuía a respeito do processo de decomposição dos resíduos sólidos.

Os excertos 10 e 11 revelaram, portanto, como as inferências conversacionais foram construídas pela interseção entre o conhecimento linguístico-textual e as experiências vividas pelos alunos. Além disso, as inferências conversacionais evidenciam a natureza cooperativa do processo conversacional a fim de que haja compreensão mútua entre os interagentes. (GUMPERZ, 1982, p. 160)

\subsection{Reflexões sobre os processos inferenciais}

Este capítulo tratou das principais teorias que estão envolvidas no processo de inferenciação e procurou mostrar, por meio da análise de alguns dados, como as inferências, que, à primeira vista, parecem ser realizadas somente por meio das reflexões relacionadas à superfície do texto, são socialmente construídas e ampliadas, uma vez que os sentidos são construídos e reconstruídos através das práticas sociais e das negociações estabelecidas entre os atores sociais no processo interacional. 
Todas as análises realizadas indicam que a inferenciação constitui atividade de natureza interacional, ancorada nas práticas sociais. Desse modo, convém destacar que as inferências, além de serem formuladas por meio do processamento cognitivo, dependem também das relações estabelecidas entre os sujeitos e o mundo, por meio da reunião dos conhecimentos linguísticos, enciclopédicos e sócio-históricos compartilhados durante as trocas verbais.

O próximo capítulo abordará os aspectos sociais, culturais e históricos que constituem a cognição humana e, além disso, alguns dados serão apresentados para ilustrar as teorias sociocognitivas que embasam esta pesquisa. 


\title{
CAPÍTULO 2
}

\section{PERSPECTIVAS SOCIOCULTURAIS DA COGNIÇÃO HUMANA}

\author{
A mente humana não pode expressar seus poderes inatos sem a habilitação dos sistemas \\ simbólicos de cultura. \\ (Jerome Bruner)
}

\subsection{Primeiras palavras}

Este capítulo apresentará teorias que vinculam a cognição humana a aspectos sociais, culturais e históricos. Será apresentada, apoiada nos estudos de Vygotsky ([1934]2001 e 1997), a perspectiva mais social e menos biológica da mente.

Após a apresentação e a discussão da teoria de Vygotsky sobre pensamento e linguagem ([1934]2001), será fundamental abordar as teorias de Tomasello ([1999] 2003, 2008, 2009) acerca dos aspectos socioculturais e históricos envolvidos na filogênese, na ontogênese e na sociogênese humana.

Por fim, as teorias de Vygotsky e as de Tomasello serão discutidas novamente com foco na mediação como construção do desenvolvimento da aprendizagem nos seres humanos, assim como no papel desempenhado pela linguagem na construção da cognição humana.

Convém ressaltar que outros autores, como Bruner (1983), Morato (2002), Salomão (2005), Friedrich (2012), Van Dijk (2009), dentre outros pesquisadores, contribuíram sobremaneira para a constituição teórica que sustenta este capítulo.

Além disso, serão apresentados dados referentes às aulas e ao grupo focal, os quais irão evidenciar a interface entre linguagem, cognição e sociedade.

\subsection{Vygotsky e a concepção social da mente}

Em seus curtos 36 anos de vida, Vygostsky construiu concisa teoria acerca do desenvolvimento humano relacionada a questões históricas e socioculturais. Seus estudos são contemporâneos aos de Piaget, teórico que defendeu a ideia do desenvolvimento humano numa perspectiva estrutural, pois o compreendia advindo de leis universais de origem biológica. Enquanto isso, Vygotsky voltava-se para estudos do desenvolvimento, que consideravam questões de cultura na interação social e na dimensão histórica do desenvolvimento mental. (IVIC, 2010, p. 12-13) 
Conforme afirma Luria (1992, p. 48), a abordagem de psicologia defendida por Vygotsky reconhecia as funções humanas internas do organismo já estudadas por outros autores, como Watson, Tolman, Skinner, Pavlov, entre outros.

Todavia, era preciso afastar-se um pouco do organismo para compreender as fontes das formas especificamente humanas das atividades psicológicas. Por isso, Vygotsky defendia o que veio a chamar de psicologia cultural, instrumental e histórica.

Cada um desses termos refletia uma característica diferente da nova abordagem que ele propôs para a psicologia. Cada qual enfatizava uma das facetas do mecanismo geral pelo qual a sociedade e a história social moldam a estrutura daquelas formas de atividades que distinguem o homem de outros animais. (LURIA, 1992, p. 48)

A psicologia instrumental é mediada por todas as funções psicológicas complexas que distinguem o homem dos demais animais. Ao diferenciar os reflexos básicos que constituem o estímulo-resposta, essa perspectiva acrescenta aos seres humanos estímulos auxiliares constituídos por aspectos culturais. (LURIA, 1992, p. 48-49). Já a psicologia cultural relaciona-se com os modos socialmente estruturados pelos quais a sociedade organiza as tarefas e ensina as crianças, oferecendo-lhes ferramentas físicas e mentais para que dominem suas atividades. Um dos instrumentos-chave criados pela humanidade é a linguagem, e Vygotsky confere a ela lugar muito importante no desenvolvimento dos processos do pensamento.

Por fim, a psicologia histórica funde-se à cultural, pois as ferramentas produzidas pelo homem não surgiram por si mesmas, mas foram criadas e aperfeiçoadas no curso da história da humanidade e constituem aspecto primordial na análise do pensamento do homem. (LURIA, 1992, p. 49)

Por conceber linguagem e cognição em seus aspectos internos e externos, Vygotsky ([1934]2001, p. 09-10) volta sua atenção para o vínculo existente entre pensamento e linguagem, criticando teorias e métodos anteriores que separam a palavra do pensamento. Consoante esse autor, é necessário que o estudo desses dois elementos seja realizado pela unidade que eles representam, ou seja, o produto da análise que, ao contrário dos elementos, conserva todas as propriedades fundamentais do todo e que não pode ser subdividido sem que aquelas se percam. (VYGOTSKY, [1934]2001, p. 11)

Palavra e pensamento constituem, assim, uma unidade a ser investigada, e o sentido das palavras, aspecto interno delas, é unidade do pensamento verbal, pois palavra e sentido se unem no pensamento verbal. Sobre isso, Vygotsky (ibid) afirma que a linguagem humana é 
um sistema mediador, haja vista que a transmissão intencional de pensamentos a outrem exige um sistema mediador, nascido da necessidade de interação durante o trabalho (ibid, p. 11). Assim, esse autor (ibid) propõe que o estudo do significado das palavras precisa concebê-las como unidade simultânea do pensamento e da linguagem. Então, a capacidade intelectiva da criança, conforme Vygotsky ([1934]2001, p. 13), está relacionada ao desenvolvimento da linguagem e à compreensão dos sentidos das palavras. Esse fenômeno, de ordem psicológica e linguística, só pode acontecer por meio do contato social.

Nesse aspecto, encontra-se o cerne da teoria de Vygotsky (ibid, p. 25) a respeito da construção social do pensamento, pois, segundo ele, a verdadeira trajetória de desenvolvimento do pensamento não vai no sentido do pensamento individual para o socializado, mas do pensamento socializado para o individual.

A conexão da interação social com o pensamento passa a ser, na teoria de Vygotsky, o ponto de partida para a compreensão da linguagem, sendo esse o aspecto que diferencia os seres humanos dos demais antropoides. A linguagem encontrada nos chimpanzés e nos demais macacos tem a ver com a emoção relacionada a alguma necessidade vital de traçar possíveis relações psicológicas com os seus iguais. Porém, a linguagem dos primatas não pode estar relacionada ao pensamento, pois ela se refere tão somente ao instinto animal. (Ibid, p. 43-44)

A respeito da ontogênese nos seres humanos, esse autor informa que

antes do ponto de viragem ${ }^{30}$, a criança reconhece (como alguns animais) um pequeno número de palavras que, tal como no condicionamento, substituem objetos, pessoas, ações, estados, desejos. Nessa idade, a criança só conhece as palavras que lhe foram transmitidas por outras pessoas. Agora a situação altera-se: a criança sente a necessidade das palavras e, por meio das suas perguntas, tenta ativamente aprender os signos relacionados com os objetos. Parece ter descoberto a função simbólica das palavras. A linguagem, que no estágio anterior era afetiva-conotativa entra agora no estádio intelectual. As trajetórias do desenvolvimento da linguagem e do pensamento encontraram-se. (VYGOTSKY, [1934]2001, p. 47)

A partir dos dois anos de idade, as crianças passam a aprender as palavras e a relacioná-las com objetos. A linguagem, que antes possuía apenas uma função instintiva, passa a ter função intelectual. A partir dessa idade, fica evidente que a linguagem não pode ser descoberta sem o pensamento. (VYGOTSKY, [1934]2001, p. 47)

\footnotetext{
${ }^{30}$ Entende-se por ponto de viragem os momentos do desenvolvimento humano caracterizados pela mudança de um nível de aprendizagem para outro.
} 
As curvas de desenvolvimento do pensamento e da linguagem (Figura 12) começam a se aproximar cada vez mais, chegando ao ponto de se encontrarem. Antes do ponto de viragem, há a fase pré-intelectual no desenvolvimento linguístico da criança; e a fase prélinguística no seu desenvolvimento intelectual. $\mathrm{O}$ discurso externo utilizado para estabelecer uma comunicação que atenda às necessidades da criança sofre transformações até chegar ao discurso egocêntrico (murmúrios e discurso semi-silencioso). Nesse estágio, pensamento e linguagem ainda não se encontraram. A partir dos 24 meses de idade, a distância entre linguagem e pensamento começa a diminuir, e o discurso interno passa a predominar, de modo que o pensamento passa a ser expresso verbalmente e a linguagem passa a ser gradualmente mais racional.

Conforme a Figura 12, até certo ponto, pensamento e linguagem, até certo ponto, se desenvolvem ao longo de diferentes linhas, independentes uma da outra. A partir desse estágio, por volta dos dois anos de idade, as duas linhas de cruzam, tornando o pensamento verbal e a linguagem intelectual. No momento em que pensamento e linguagem se encontram, ocorre a significação verbal, ou seja, unidade plena do sentido das palavras. (MORATO, 2002, p. 50)

Figura 12 - Pensamento e linguagem na ontogênese.

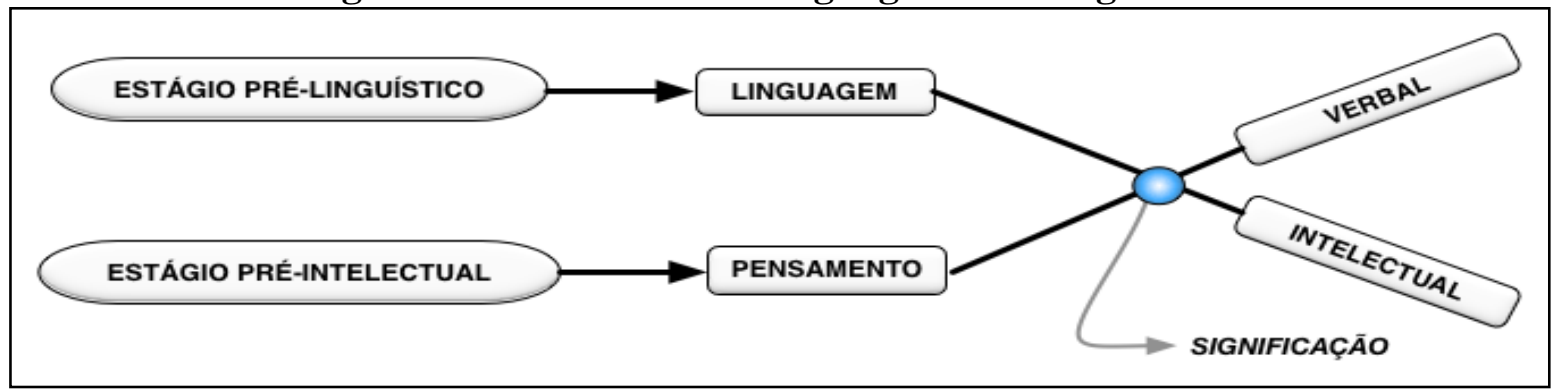

Fonte: Autoria própria

Morato (2002, p. 47-48) afirma que o discurso egocêntrico ${ }^{31}$, na teoria de Vygotsky, é um estágio de evolução da linguagem externa (LE) para linguagem interna (LI), que guarda da linguagem externa algumas prioridades linguísticas. Para a autora (ibid), a existência de um discurso egocêntrico torna emergente uma nova função autorreguladora e reflexiva da linguagem, que é fundamentada pela relação entre linguagem externa, fala egocêntrica e linguagem interna. Esse processo concebe a linguagem como ação organizadora, transformadora e significativa, que, por sua vez, regula a atividade humana. (Ibid, p. 50)

\footnotetext{
${ }^{31}$ Nos termos de Morato, discurso egocêntrico é denominado fala egocêntrica.
} 
Percebe-se, então, a presença da linguagem externa como ponto de partida para a construção do discurso interior, o que equivale afirmar ser o desenvolvimento do pensamento determinado pela linguagem, ou melhor, pelos instrumentos linguísticos do pensamento. (VYGOTSKY, [1934]2001, p. 54)

Vygotsky (ibid) conclui, finalmente, que existe uma fusão entre pensamento e linguagem (Figura 13) e ela se manifesta tanto na linguagem dos adultos como na linguagem das crianças. Porém, convém ressaltar que pensamento e linguagem não se fundem por completo, mas somente numa área circunscrita. Fora dessa área estão o pensamento não verbal e a linguagem não-intelectual, que só indiretamente são afetados pelos processos do pensamento verbal. (Ibid, p. 51)

Figura 13 - Fusão: pensamento e linguagem.

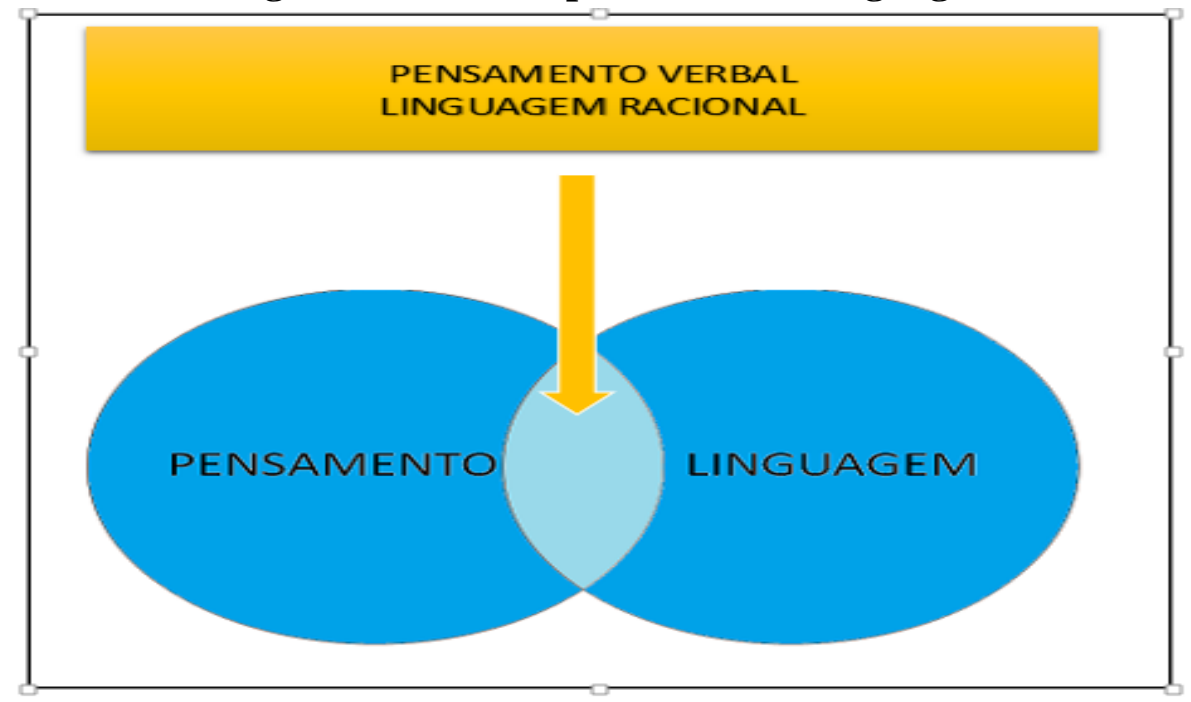

Fonte: autoria própria.

Se o pensamento verbal está mediado e impregnado pela linguagem (MORATO, 2002, p. 50), então a linguagem está tomada de pensamento. Assim, o falar impulsiona o pensar, na visão de Vygotsky. (FRAWLEY, 2000, p. 38)

$\mathrm{O}$ desenvolvimento da linguagem da criança está atrelado às questões sociais e históricas, portanto, o desenvolvimento do comportamento será essencialmente governado pelas leis gerais do desenvolvimento histórico da sociedade humana. (VYGOTSKY, [1934]2001, p. 55)

As atividades humanas são reguladas, assim, pela linguagem. A consciência e os conceitos estão diretamente relacionados ao desenvolvimento linguístico dos seres humanos e à interação social/interação verbal. (VYGOTSKY, [1934]2001; MORATO, 2002) 


\begin{abstract}
A formação dos conceitos é resultado de uma complexa atividade em que todas as funções intelectuais fundamentais participam. No entanto, este processo não pode ser reduzido à associação, à tendência, à imagética, à inferência ou às tendências determinantes. Todas estas funções são indispensáveis, mas não são suficientes se não se empregar o signo ou a palavra, como meios pelos quais dirigimos as nossas operações mentais, controlamos o seu curso e o canalizamos para a solução do problema com que nos defrontamos. (VYGOTSKY, [1934]2001, p. 61)
\end{abstract}

Logo, a cognição é constituída socialmente e se encontra na interiorização da linguagem externa, por meio de um processo que envolve nexos associativos e que evolui para o pensamento complexo no decorrer da ontogênese humana. Durante esse processo, a criança passa pelo pensamento sincrético, caracterizado por nexos vagos e subjetivos; pelo pensamento complexo, quando os nexos associativos começam a ser executados e os referentes da criança passam a coincidir com o dos adultos; e, finalmente, ela alcança o pensamento por conceitos, no qual os significados das palavras passam a se relacionar a um ou mais referentes. (VYGOTSKY, [1934]2001, pp. 66-71)

Os conceitos, assim, não são ensinados por um mero repasse de significações. Consoante Vygotsky,

a experiência prática mostra (...) que é impossível e estéril ensinar os conceitos de uma forma direta. Um professor que tenta conseguir isto habitualmente, mais não consegue da criança do que um verbalismo oco, um psitacismo que simula um conhecimento dos conceitos correspondentes, mas que na realidade só encobre um vácuo. (VYGOTSKY, [1934]2001, p. 84)

Os conceitos não podem ser unicamente ensinados, mas partilhados socialmente por meio das experiências advindas das tradições culturais construídas historicamente. Vygotsky assume, então, postura linguística funcionalista, abandonando o ato linguístico baseado na forma e na estrutura. Percebe-se, nessa perspectiva, a multifuncionalidade da linguagem, que obedece a objetivos das diversas situações e ações linguísticas. (MORATO, 2002, p. 56)

Como expresso nas Figuras 12 e 13, a significação é gerada num amálgama entre pensamento e linguagem, no qual torna-se imperceptível onde um começa e o outro termina. Assim, nos termos de Vygotsky, uma palavra sem significado é um som vazio; portanto, a significação é um fenômeno linguístico que faz parte da palavra, constituindo componente indispensável a ela. Por isso, a significação é ato tanto da linguagem como do pensamento e, por essa razão, o falar impulsiona o pensar. (VYGOTSKY, [1934]2001, p. 119; FRAWLEY, 2000, p. 38 e MORATO, 2002, p. 61)

A relação entre o pensamento e a palavra não é uma coisa, mas um processo, um movimento contínuo de vaivém entre a palavra e o pensamento; nesse processo a relação entre o pensamento e a palavra sofre alterações que, também elas, podem ser 
consideradas como um desenvolvimento no sentido funcional. As palavras não se limitam a exprimir o pensamento: é por elas que este acede à existência. Todos os pensamentos tendem a relacionar determinada coisa com outra, todos os pensamentos tendem a estabelecer uma relação entre coisas, todos os pensamentos se movem, amadurecem, se desenvolvem, preenchem uma função, resolvem um problema. Esta corrente do pensamento flui como um movimento interno através de uma série de planos. Qualquer análise da interação entre o pensamento e a palavra terá de principiar por investigar os diferentes planos e fases que um pensamento percorre antes de se encarnar nas palavras. (VYGOTSKY, [1934]2001, p. 124)

A teoria discutida até aqui revela que a significação é construída por meio da simbiose pensamento e linguagem, sendo ambos formados por meio das interações sociais estabelecidas pelos sujeitos que aprendem a falar e a pensar, integrados no processo sóciohistórico-cultural no qual se encontram inseridos. A construção de significação será tratada neste trabalho como construção de sentidos, e os dados revelarão que é por meio das interações sociais estabelecidas entre a professora-pesquisadora e os estudantes, somadas às experiências prévias desses atores sociais, que os sentidos são edificados, discutidos, reformulados e reedificados no processo dinâmico da construção social da cognição humana.

Por essa razão, há preponderância do sentido sobre o significado das palavras no que tange à constituição do discurso interior (vide nota de rodapé, p. 25 ), pois, para Vygotsky, os significados são imóveis e engessados ao passo que o sentido ${ }^{32}$ da palavra diz respeito a todos os fatos psicológicos que ela desperta na consciência. O significado constitui uma das zonas do sentido, haja vista que este é amplo e determinado pelo contexto, podendo ter mais de um referente. Isso torna palavra e sentido relativamente independentes entre si. (Ibid, pp. 144145)

Além de haver preponderância do sentido sobre o significado no discurso interior, a frase é também superior à palavra, e o contexto é superior à frase. Portanto, as questões contextuais constituem quesito imprescindível na constituição do discurso interior e, por conseguinte, na exteriorização do pensamento por meio da verbalização.

A última característica apresentada por Vygotsky acerca do discurso interior é o modo como os sentidos das palavras se combinam e se congregam. Esse é um processo regido por leis diferentes daquelas que conduzem a combinação dos significados. A aglutinação que ocorre no discurso interior faz com que ocorra um influxo de sentido. Nele,

os sentidos de diferentes palavras confluem numa outra - "influenciam-se" literalmente — de forma que as primeiras estão contidas nas últimas e as

\footnotetext{
32 Por esta razão, neste trabalho, o termo sentido será escolhido para tratar das inferências realizadas pelos colaboradores de pesquisa.
} 
influenciam. Da mesma forma, uma palavra que continuamente se repete num livro ou num poema absorve por vezes todas as variantes de sentido neles contidas e se torna, de certa maneira, equivalente à própria obra. (VYGOTSKY, [1934]2001, p. 145)

Por essa razão, o discurso interior, advindo do influxo de sentidos, atinge incidência máxima na atividade do pensamento, tornando esse discurso ininteligível, caso fosse transposto para o discurso externo do modo como se configurou. Ele constitui fenômeno autônomo da linguagem pelo tanto que se distancia do pensamento verbal. Portanto, o discurso interior será um rascunho para o discurso escrito e para o discurso oral, pois a transição do pensamento para as palavras se dá de forma bastante complexa.

Essas afirmações não tornam a teoria de Vygotsky internalista. Ao contrário disso, a ideia central é a de que a organização interna da linguagem é estruturada nas regularidades enunciativo-discursivas constitutivas das interações humanas. (MORATO, 2002, p. 63), colaborando, assim, para que todo o processo cognitivo seja mediado pelo pensamento e pelas práticas linguísticas externas.

É nesse interstício que se encontra a função reguladora da linguagem, defendida por Morato (2002) e comprovada por meio dos dados desta pesquisa. É na humanização das coisas do mundo (ibid, p. 75), por meio do processo de interiorização, somados à consciência trazida pela experiência social que os sentidos são construídos. A atividade cognitiva possui, nesse contexto, concepção dialógica, visto que se relaciona às propriedades interativas humanas e à linguagem, sendo que esta põe essa relação em evidência, pois media o social e o cognitivo.

\subsection{A construção sociocultural do conhecimento}

Após as discussões anteriores relativas à concepção social da mente e da relação entre pensamento e linguagem na construção da cognição, faz-se necessário apresentar como os estudos de Tomasello ([1999]2003, 2008, 2009) se relacionam com as teorias de Vygotsky e as complementam quando acresce a elas o aprofundamento da perspectiva cultural na formação do conhecimento humano.

Mesmo que Vygotsky tenha desenvolvido, em parceria com outros pesquisadores, estudos focalizados na filogênese, quando analisaram o comportamento de chimpanzés contrapondo-o com as práticas sociais dos seres humanos, é nos estudos de Tomasello que foram mais enfatizadas as questões sociais e históricas, responsáveis por delinear a 
ontogênese da cognição humana, as quais dizem respeito à evolução da linguagem e do pensamento no decorrer dos primeiros anos de vida.

Tomasello ([1999]2003, 2008 e 2009), assim, focaliza seus estudos na aquisição do conhecimento humano em três perspectivas: (1) filogenética, (2) histórica (sociogênese) e (3) ontogenética. Essas constituem, para ele, qualidades únicas da cognição humana.

Os estudos da filogênese indicam que os seres humanos modernos desenvolvem a capacidade de se identificar com seus co-específicos e, durante esse processo de adaptação cultural, aprendem a agir socialmente por meio da imitação do comportamento de outrem. Essa imitação não seria viável se não fosse a sociogênese, aprendizagem baseada nos artefatos culturais e nas tradições comportamentais. A ontogênese diz respeito a como as crianças humanas crescem no meio de artefatos e de tradições social e historicamente construídos, os quais as beneficiam dos conhecimentos e das habilidades acumuladas pelos grupos sociais dos quais fazem parte, levando-as a adquirir e a usar representações cognitivas, além de internalizar alguns tipos de interações discursivas - o que promove a capacidade de metacognição, redescrição representacional e pensamento dialógico. (TOMASELLO, [1999]2003, p. 13-14)

A cognição humana é, portanto, produto da evolução cultural cumulativa ou efeito catraca, que exige, além da invenção criativa própria da raça humana, principalmente, a transmissão social confiável que funcione como uma catraca para impedir o resvalo para trás de maneira que o recém-inventado artefato ou prática preserve sua forma nova e melhorada de forma bastante fiel pelo menos até que surja uma outra modificação ou melhora (ibid, p. 06-07). Esse processo se justifica pelo fato de que os seres humanos possuem a habilidade de combinar os recursos cognitivos fornecidos pela sociogênese de maneira diferente dos outros animais, que reproduzem comportamentos somente para preservação da espécie, não sendo capazes de modificar os artefatos culturais.

A cognição social, denominada por Tomasello ([1999]2003, p. 07), é produto da aprendizagem cultural humana, constituída de aprendizagem por imitação, aprendizagem por instrução e aprendizagem por colaboração. Esses três elementos referem-se à capacidade de cada ser humano se identificar com seus co-específicos como seres iguais a ele, com vidas mentais e intencionais iguais às deles (...) Essa compreensão permite aos indivíduos imaginarem-se na "pele mental" de outra pessoa, fazendo-os aprenderem não só do outro, mas através do outro. (Ibid, p. 07) 
Processos de aprendizagem cultural são formas especialmente poderosas de aprendizagem social porque constituem (a) formas especialmente confiáveis de transmissão cultural (criando uma catraca cultural particularmente poderosa) e $(b)$ formas especialmente poderosas de criatividade e inventividade sociocolaborativa, ou seja, processos de sociogênese nos quais indivíduos criam algo juntos, algo que nenhum indivíduo poderia criar sozinho. (TOMASELLO, [1999]2003, p. 07-08)

Por essa razão, é que somente os seres humanos se envolvem numa aprendizagem cultural não apenas por estarem imersos numa cultura. Existem razões genéticas, também discutidas por Vygotsky ([1934]2001 \& 1991) e aprofundadas por Tomasello ([1999]2003, p. 09), que aconteceram num dado momento da evolução da humanidade e ofereceram aos seres humanos aparatos biológicos para os processos de cognição cultural. Essa adaptação biológica pela qual passaram os seres humanos não gerou novas habilidades cognitivas do nada, mas tomou habilidades cognitivas já existentes, transformando-as em novas habilidades cognitivas culturais com uma dimensão sociocoletiva (ibid). Esse processo não acontece no tempo evolucionário, mas no tempo histórico.

Tomasello ([1999]2003, p. 11) explica que os artefatos simbólicos representam arsenal importante para crianças em desenvolvimento por incorporarem meios pelos quais as gerações anteriores de seres humanos de um grupo social consideraram proveitoso categorizar e interpretar o mundo para fins de comunicação interpessoal. Fazem parte deles os símbolos linguísticos, os quais produzem cognição humana referente a uma situação perceptual entendida não de maneira externa, mas a partir das representações simultâneas que essas situações permitem executar.

Vygotsky (1991, p. 20) apresenta a mesma concepção, mas com outro termo, nomeado por ele de atividade simbólica: uma função organizadora específica que invade o processo do uso de instrumento e produz formas fundamentalmente novas de comportamento. Para esse autor (ibid, p. 24), o arcabouço cultural construído por meio da história social irá delinear o comportamento humano, que possui estrutura complexa, formada, nas palavras dele, por um processo de desenvolvimento profundamente enraizado nas ligações entre história individual e história social.

Assim, o que Tomasello ([1999]2003) nomeia como artefatos simbólicos, Vygotsky (1991) chamou de atividade simbólica. Ambos revelam que as práticas sociais nas quais os sujeitos estão imersos delineiam a construção do conhecimento humano, o qual deve ser concebido como processo sócio-histórico. Isso significa que a cognição não pode ser construída como processo tão somente mental, em função de características biológicas que os seres humanos possuem e os demais animais, não. Em vez desse pensamento, as teorias 
psicológicas apresentadas, até o momento, revelam que é a sociocognição a responsável pela manutenção e pela evolução dos artefatos simbólicos ou das atividades simbólicas de uma sociedade.

Para que esse processo ocorra, a metáfora da catraca, já apresentada, evidencia como ocorre a evolução cultural cumulativa, que depende de dois fatores: a aprendizagem por imitação, através da atividade instrutiva realizada pelos adultos; e a inovação, pela capacidade de aprendizagem sociocognitiva para criar, enquanto espécie, produtos cognitivos únicos baseados na evolução cultural cumulativa. (TOMASELLO, [1999]2013, p. 53 e p. 55)

$\mathrm{O}$ autor (ibid, p. 58) se refere, então, à sociogênese da linguagem, caracterizada pela inventividade criativa própria dos seres humanos, pois todos os símbolos e construções de uma língua não foram inventados de uma só vez, e, depois de inventados, não permanecem idênticos por muito tempo (Ibid, p. 58), ao contrário, eles são modificados criativamente no decorrer da evolução cultural humana.

Assim sendo, há uma herança dual, que é produto da linha individual do desenvolvimento cognitivo e que se refere à capacidade biológica de viver culturalmente, própria dos seres humanos, somada à linha cultural do desenvolvimento cognitivo, que concerne às coisas reconhecidas e aprendidas pelo ser humano quando ele entra em contato com outras pessoas e passa a ver o mundo através do ponto de vistas delas. (Ibid, p. 71)

Sobre esse contato interpessoal, Sperber \& Wilson (1995, p. 216-217) defendem que, na interação, as pessoas pressupõem normalmente que a resposta dada pelos seus interlocutores compreende um tópico-relevante, adequando a ela uma interpretação que o torne realmente relevante. Tal ação facilita o entendimento da mente dos interagentes, pois, em concordância com Tomasello ([1999]2003, p. 71), é necessário inserir-se no ponto de vista do outro para enxergar o mundo sob a mesma ótica. Gopnik (1993, p. 331) afirma que nós conhecemos os estados intencionais dos outros tão bem como conhecemos os nossos, e, em certos casos, ainda melhor. Trata-se, portanto, da união entre herança individual e herança cultural com o propósito de manutenção dos artefatos simbólicos construídos historicamente.

Todo esse processo constitui o que Tomasello ([1999]2003, p. 75) nomeia de aprendizagem cultural, e só pode ocorrer por meio da prática da atenção conjunta. Consoante esse autor, aos noves meses de idade, ocorre a revolução que leva à atenção conjunta, pois é neste período que os bebês humanos começam a indicar a compreensão das outras pessoas como agentes intencionais iguais a eles. Essas relações com entidades externas podem se 
realizar de forma acompanhada, dirigida ou compartilhada, colaborando para que os bebês se envolvam com os adultos em longas sessões de interação social, por meio do acompanhamento do olhar e do uso de gestos dêiticos imperativos e declarativos, que começam aos nove meses de idade e prolongam-se até os quinze meses. Esses símbolos linguísticos geram uma miríade de formas para interpretar intersubjetivamente o mundo, acumuladas no tempo histórico por meio da cultura. Nas ocasiões de interação entre crianças e adultos, ambos prestam conjuntamente atenção a uma terceira coisa, e à atenção um do outro à terceira coisa, por um período razoável de tempo. (Ibid, p. 135)

Os resultados da pesquisa de Tomasello acerca do desenvolvimento ontogênico dos seres humanos indicam, mais uma vez, que há um nicho ontogenético herdado, resultado da união entre o meio ambiente e o genoma humano e que possui grande riqueza cultural. Assim, o ambiente cultural humano proporciona o contexto ideal para o desenvolvimento cognitivo das crianças, pois possui o habitus cognitivo, que oferece instrução ativa por parte dos adultos. (TOMASELLO, [1999]2003, p. 109-110)

Poressa razão, tanto na andaimaria quanto na instrução direta, o adulto se interessa pela aquisição, por parte da criança, de uma habilidade ou parcela de conhecimento. (TOMASELLO, [1999]2003, p. 111). Assim, o interesse do adulto (ou interagente mais experiente) em instruir e o das crianças (ou sujeito menos experiente) de aprender terá como resultado a aprendizagem por imitação, na qual as crianças imitam o comportamento intencional dos adultos, mas sem reproduzirem os efeitos que os adultos provocam nos objetos. (Ibid, p. 114)

\footnotetext{
A aprendizagem por imitação representa a entrada inicial das crianças no mundo cultural que as rodeia no sentido de que agora podem começar a aprender dos adultos, ou, mais precisamente, por meio dos adultos, de modos cognitivamente significativos. (TOMASELLO, 2003, p. 116)
}

Assim, a partir da idade em que as crianças se encontram aptas para aprenderem por meio da interação com os demais, elas passam a compreender que estão usando o mesmo comportamento dos outros, compartilhando, desse modo, os artefatos simbólicos e, posteriormente, compreendendo a si mesmas e internalizando os conhecimentos adquiridos. Percebe-se, portanto, a correspondência do conceito de aprendizagem por imitação, apresentado por Tomasello ([1999] 2003, p. 125), com os estudos de Vygotsky ([1934]2001 e 1991) acerca das origens ontogenéticas da linha cultural de desenvolvimento cognitivo. 
Ambos apontam para a concepção de cognição formada por meio da interação com o mundo externo, para uma posterior interiorização e compreensão do $e u$.

É durante as cenas de atenção conjunta que a atividade linguística é desenvolvida a ponto de se tornar atividade simbólica essencial para as práticas interacionais do sujeito ao longo da vida, pois elas fornecem o contexto intersubjetivo no qual ocorre o processo de simbolização. Nesse processo, a criança começa a compreender o que os outros dizem para ela e, posteriormente, começa a imitar e, na prática linguística, desenvolvida por meio da imitação com a inversão de papéis, ela começa a utilizar com independência os símbolos linguísticos.

\begin{abstract}
Para adquirir o uso convencional de um símbolo linguístico, a criança tem que ser capaz de determinar as intenções comunicativas do adulto (...) e então envolver-se num processo de imitação com inversão de papéis no qual usa o novo símbolo em relação ao adulto da mesma maneira e com o mesmo propósito comunicativo do adulto em relação a ela. (TOMASELLO, [1999] 2003, p. 163)
\end{abstract}

Ao se tornarem adultos, os seres humanos criam outras formas de representação simbólica (metáfora da catraca), ao utilizarem símbolos exógenos, socialmente construídos e divulgados publicamente por meio de diversos gêneros de textos orais e escritos. Esse processo tem consequências visíveis na construção da representação simbólica interna, haja vista que é por meio das interações sociais que o ser humano internaliza as práticas sociais e compreende o mundo no qual interage. Assim, defende-se que a linguagem é utilizada de modo criativo para argumentação e solução de problemas. Para Vygotsky (1991, p. 22),

\begin{abstract}
a maior mudança na capacidade das crianças para usar a linguagem como um instrumento para a solução de problemas acontece um pouco mais tarde no seu desenvolvimento, no momento em que a fala socializada (que foi previamente utilizada para dirigir-se a um adulto) é internalizada. Ao invés de apelar para o adulto, as crianças passam a apelar a si mesmas; a linguagem passa, assim, a adquirir uma função intrapessoal além do seu uso interpessoal. (VYGOTSKY, 1991, p. 22)
\end{abstract}

É desse modo que são formadas as funções psicológicas superiores. No momento em que as funções comunicativas necessitam de atividades mediadas por signos, pois, para o processamento cognitivo, faz-se necessária a ação do ser humano, que modifica o ambiente por meio do uso dos instrumentos psicológicos. Estes, na concepção de Friedrich (2012, p. 58), possuem três características a serem inferidas nas obras de Vygotsky: (1) são manifestações artificiais; (2) possuem natureza não-orgânica, ou seja, social; (3) são destinados ao controle dos próprios comportamentos psíquicos e também do outro - um outro coletivo - que veicula a cultura. 
Essa concepção inclui os signos no domínio dos instrumentos simbólicos, porém, Vygotsky (1991) acrescenta que se trata de todos os signos possíveis: a linguagem, as diversas formas de contar e de cálculo, os símbolos algébricos, as obras de arte, a escrita, os esquemas, os diagramas, os mapas, entre outros. Numa concepção mais atual, são os textos verbais e não verbais relacionados a práticas sociais diversas que formam os instrumentos simbólicos.

Portanto, essa característica, segundo Vygotsky (1991, p. 37-38), diferencia filogeneticamente os seres humanos dos demais primatas.

\begin{abstract}
A verdadeira essência da memória humana está no fato de os seres humanos serem capazes de lembrar ativamente com a ajuda de signos. Poder-se-ia dizer que a característica básica do comportamento humano em geral é que os próprios homens influenciam sua relação com o ambiente e, através desse ambiente, pessoalmente modificam seu comportamento, colocando-o sob seu controle. Tem sido dito que a verdadeira essência da civilização consiste na construção propositada de monumentos de forma a não esquecer fatos históricos. (VYGOTSKY, 1991, p. 3738)
\end{abstract}

As funções psicológicas superiores são formadas quando a criança consegue utilizar os instrumentos sociais externos por meio da interiorização de signos linguísticos e nãolinguísticos, pois, para Vygotsky, qualquer objeto da realidade pode se tornar um signo, quando internalizado. (FRIEDRICH, 2012, p. 58)

\title{
2.3 Mediação, aprendizagem e desenvolvimento
}

Todos os processos para constituição da cognição social humana, por meio das funções mentais superiores, são realizados por meio da mediação, da aprendizagem e do desenvolvimento. Nenhum desses elementos, nas teorias discutidas até agora, existem se desconectados das questões históricas e sociais. Assim, a interiorização do conhecimento passa, antes, pela interação com o outro.

A partir dessas premissas, será situado o contexto educacional no qual se insere esta pesquisa, a fim de iniciar discussão acerca das teorias socioculturais que abordam a construção da cognição. O arcabouço teórico será aplicado à realidade da aula de leitura e compreensão de textos numa turma do curso de técnico subsequente em secretariado escolar, com alunos adultos. 
Percebe-se que os alunos já passaram por todos os processos de desenvolvimento da cognição elencados anteriormente, ao ponto de já terem adquirido as funções psicológicas superiores e de já haverem incorporado os artefatos simbólicos que fazem parte de suas realidades. Porém, a escolha que eles fizeram (a matrícula em um curso técnico) parte da motivação de querer adquirir mais conhecimentos que forneçam a eles habilidades para a realização da prática profissional com proficiência.

O processo de interação em sala de aula é constituído de cenas de atenção conjunta (TOMASELLO, [1999]2003) mediadas pelos agentes da interação (VYGOTSKY, 1991, p. 56). O desenvolvimento da aprendizagem é, então, um processo construído por meio das trocas verbais e não verbais entre professores e alunos, assim como entre alunos e alunos. Sobre isso, Vygotsky (1991) defende a aprendizagem como resultado do processo iniciado com as experiências sociais que constituem a história do aluno; as de nível intelectual ou enciclopédico; e as experiências resultantes de práticas vivenciadas fora de escola. A aprendizagem, desse modo, será o resultado das experiências sociais somadas àquelas aprendidas na escola, por meio do professor ou de um colega mais experiente. Vygotsky (1991, p. 58) nomeia esse processo de Zona de Desenvolvimento Proximal (ZDP), que constitui

\begin{abstract}
a distância entre o nível de desenvolvimento real, que se costuma determinar através da solução independente de problemas, e o nível de desenvolvimento potencial, determinado através da solução de problemas sob a orientação de um adulto ou em colaboração com companheiros mais capazes. (...) O nível de desenvolvimento real caracteriza o desenvolvimento mental retrospectivamente, enquanto a zona de desenvolvimento proximal caracteriza o desenvolvimento mental prospectivamente. (VYGOTSKY, 1991, p. 58)
\end{abstract}

Logo, a teoria de Vygotsky postula que a aprendizagem é efetivada no momento em que o sujeito tem contato com um interagente mais experiente, o qual dá continuidade ao processo de construção de conhecimentos. Ou seja, o sujeito caminha até um certo ponto determinado por ele (desenvolvimento real), e o interlocutor mais experiente poderá fornecer pistas que o faça progredir em sua cognição no momento em que precisar desse auxílio (desenvolvimento potencial).

Morato (2002, p. 89) indica que, para Vygotsky, a interação social e o processo educacional são motores de transformação qualitativa da cognição humana. A introdução do conceito da ZDP demonstra, no contexto educacional, que o "bom aprendizado" é aquele que vem antes do desenvolvimento (VIGOTSKY, 1991, p. 60). O que é a ZDP de um aluno no presente se transformará em aprendizagem e desenvolvimento no futuro. Assim, a concepção de aprendizagem rompe as ideias tradicionais de que ensinar é inserir um conteúdo em um 
"vaso vazio". Ao contrário disso, Vygotsky (1991) defende que todos possuem suas zonas de desenvolvimento proximal e que, por meio da interação social, os seres humanos vão transformando o nível de desenvolvimento proximal, até então não alcançado, em desenvolvimento real. Portanto,

(...) os processos de desenvolvimento não coincidem com os processos de aprendizado. Ou melhor, o processo de desenvolvimento progride de forma mais lenta e atrás do processo de aprendizado; desta sequenciação resultam, então, as zonas de desenvolvimento proximal. (VYGOTSKY, 1991, p. 61)

A concepção de ZDP ratifica, mais uma vez, que a linguagem é o meio principal de mediação da atividade cognitiva, e as práticas de ensino devem considerar as formas de interação que interligam aprendizagem e desenvolvimento. (MORATO, 2002, p. 92 e p. 103)

Ressalta-se também a conexão do conceito de ZDP com a noção de andaime (scaffolding), introduzida por Wood, Bruner \& Ross (1976) e muito divulgada e estudada em contextos educacionais por Bortoni-Ricardo \& Sousa (2003). Nesse ponto, Friedrich (2012, p. 109-10), a partir de seus estudos sobre a teoria de Vygotsky, demonstra que a concepção de ZDP, na qual a aprendizagem precede o desenvolvimento, trata-se somente de uma primeira tese de Vygotsky acerca do desenvolvimento da aprendizagem. Há uma segunda tese que contrapõe a primeira. Nela, o ritmo de desenvolvimento não coincide com o ritmo das aprendizagens. Para Friedrich (2012, p.111),

\footnotetext{
(...) essa segunda tese é indispensável para poder supor a verdadeira interdependência entre aprendizagem e desenvolvimento, uma interdependência na qual nenhum tem prioridade sobre o outro. Essa tese sobre a incomensurabilidade permite justamente afirmar que não é apesar do desenvolvimento, mas graças a ele que as aprendizagens se realizam. (...) As aprendizagens não garantem automaticamente que um aluno seja "afetado" por elas, ou, em outras palavras, que ele seja sensível a elas.
}

Vygotsky classifica as leis das aprendizagens como externas ou artificiais, pois elas não coincidirão com as leis internas dos processos de desenvolvimento desencadeados pelas aprendizagens. Todavia, afirmar que as aprendizagens não coincidem com o desenvolvimento não significa que eles nunca se encontrarão. Ao contrário disso, trata-se do objetivo do ensino regulamente atestado nas práticas escolares. (FRIEDRICH, 2012, pp. 111-112)

Friedrich (2012, p. 112) explicita ser exatamente nesse ponto de cruzamento entre as aprendizagens e o desenvolvimento que haverá mudança no aluno. Essa autora (ibid) reforça a ideia de Vygotsky do caráter brusco e não contínuo das mudanças suscitadas pelas 
aprendizagens, quando esse teórico se volta para a escola de Würzburg para tomar o termo, utilizado por eles, chamado de Aha-Erlebnis, traduzido como experiência estalo ou experiência de eureca. Trata-se do momento no qual ocorre uma clarificação, uma compreensão, um pensamento de forma repentina, instantânea, normalmente expresso pela expressão: agora eu sei (FRIEDRICH, 2012, p. 112).

A experiência estalo também é expressão usada para se referir ao estalo de Vieira, relacionada ao Padre Antônio Vieira, que conferia seus conhecimentos para escritura dos sermões a um estalo advindo, segundo ele, das preces realizadas à Nossa Senhora das Maravilhas durante os tempos de noviciado na Companhia de Jesus. Esse padre jesuíta nada entendia a respeito do texto bíblico e das demais leituras solicitadas nos tempos de noviciado. Essa dificuldade o fazia ser motivo de chacota entre colegas e mestres. Porém, depois de muitas preces direcionadas à virgem Maria, aconteceu o estalo e ele passou a compreender aquilo que era lido e ensinado. Assim, passou a ser o destaque na arte de argumentar, surpreendendo seus mestres ${ }^{33}$.

Assim, os dados presentes no corpus desta pesquisa indicam o caráter mediador da construção da aprendizagem. O estalo de Vieira, compreendido à luz das teorias discutidas, demonstra que o momento da clarificação é uma experiência que acontece nos momentos de interação com o texto, com o contexto e com a situação interativa construída em sala de aula por meio de atividades de leitura mediada, sendo assim, uma experiência sociocognitiva.

O texto 06 foi a primeira atividade de leitura coletiva e com mediação da professorapesquisadora. $\mathrm{O}$ excerto $12 \mathrm{diz}$ respeito a uma discussão coletiva, na qual a professorapesquisadora e os alunos dialogavam acerca dos sentidos presentes no texto. Nesse excerto, a pesquisadora reapresenta o texto 06 , pois havia iniciado a discussão sobre ele no final da primeira aula, mas não havia tido tempo hábil para obter as conclusões juntamente com os alunos.

\footnotetext{
${ }^{33}$ Trecho da obra História de Vieira, escrita por Lúcio de Azevedo, em 1918. Este trecho relata o momento em que Vieira teve o estalo: sentiu como estalar qualquer cousa no cérebro, como uma dor vivíssima, e pensou que morria; logo o que parecia obscuro e inacessível à memória, na lição que ia dar, se lhe volveu lúcido e fixo na retentiva. Dera-se lhe na mente uma transformação de que tinha consciência. Chegado às classes pediu para argumentar, e com pasmo do mestre venceu a todos os condiscípulos. (Disponível na obra História de António Vieira, publicada em 1931.)
} 


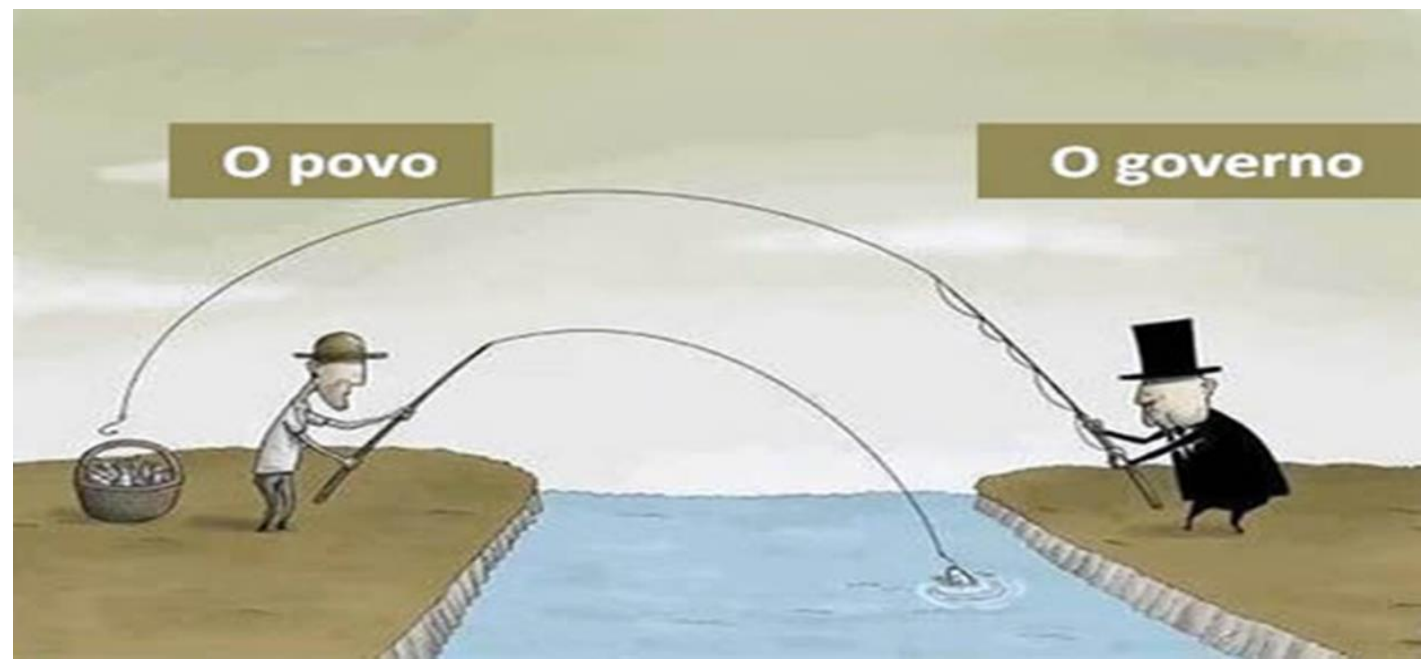

Disponível em: http://www.blogdomadeira.com.br/wp-content/uploads/2013/12/Charge-o-povo-e-o-governo.jpg. Acesso em 13/03/2015.

\section{Excerto 12 - Aula 03}

01 Professora: Vocês lembram sobre o que vocês falaram? ((05 segundos de silêncio))

02 Governo? Alguém falou "governo", "povo"? Está escrito "povo" "governo"... ok... Mas:.::

03 /.../ Ah... quem está pegando o pescado, o peixe?

04 Aluna 3: O governo

05 Professora: O governo pega o quê?

06 ((Vários alunos falam juntos))

07 Professora: O peixe do povo, né? Mas é interessante quando a gente olha os desenhos.

08 Como eles estão posicionados? Eles estão um ao lado do outro?

09 Alunas: Não

10 Professora: Eles estão o quê?

11 Aluna 3: De lados diferentes.

12 Professora: De lados opostos, de lados diferentes. Tem uma coisa interessante também.

13 Porque o povo tem uma coisa que o governo não tem. Que que o povo tem e o governo não

14 tem? (E aí?). Na imagem... ((silêncio))

15 Aluna 4: Tem peixe.

16 Professora: Tem peixe. Observem que desse lado é o povo, né? Desse lado, o povo tem

17 uma cestinha pra guardar esse peixe. O governo tem alguma cesta aqui aparecendo?

18 ((apontando para os slides))

19 Alunas: Não.

20 Professora: O povo?... Pobre e o rico. É... o que mais? Por que que a gente fala que é o

21 pobre e o rico?... O que nos faz perceber que um é pobre e outro é rico?

A professora-pesquisadora iniciou a discussão relembrando os sentidos já partilhados na aula anterior. No entanto, poucos alunos se lembravam do texto, enquanto outros relataram que estiveram ausentes na aula anterior. Por essa razão, para a maioria dos alunos presentes, o processo de compreensão do texto teve início naquele momento. A princípio, o primeiro comentário dos alunos a respeito da charge foi sobre o que estava na linguagem verbal o povo 
e o governo. Fez-se necessário que a professora (linhas 01-03) conduzisse a atenção dos alunos para que eles percebessem os detalhes das imagens: exercício repetido, principalmente, durante as primeiras aulas.

Após os alunos começarem a observar a imagem, a professora-pesquisadora iniciou o processo de construção dos andaimes, oferecendo a eles pistas verbais (linhas 05, 07, 08, 10, $13,14,16,17)$. Até a linha 19, a professora-pesquisadora fez perguntas para despertar a atenção dos discentes para os sentidos da imagem, mas obteve somente respostas curtas dos alunos, cuja ZDP ainda estava na fase do desenvolvimento real. (VYGOTSKY, 1991, p. 58)

Ao perceber um sussurro de uma aluna (que não foi possível transcrever), a professora voltou-se para ela (linha 20) e continuou a questionar os estudantes sobre quais características na imagem os fazia perceber a condição de pobre, para o povo, e de rico, para o governo. (Excerto 13)

\section{Excerto 13 - Aula 03}

01 Aluna 2: Dá a entender que o pobre é que trabalha e o rico que fica com o lucro.

02 Professora: Isso. Mas existe uma característica, mas ela falou que é o pobre e o rico. Mas 03 sabemos, quando a gente olha, a gente já percebe logo, de cara... Que um representa o pobre e 04 outro representa o rico. Mas... Quais são os elementos do desenho, que nos fazem....

06 Aluna 4: A roupa.

$07 \quad$ l...l

08 Aluna 2: Tá trabalhando, professora. O pobre é que tá trabalhando.

09 Professora: O pobre tá trabalhando. Existe um outro elemento importante também, que faz 10 parte desse entendimento nosso de que o pobre trabalha e o governo surrupia aquilo que o pobre 11 produziu. Observem a vara de pescar do governo e a vara de pescar do pobre. Existe uma 12 diferença bem grande entre elas... E tem um que tá na vantagem. Por quê? /.../

13 l.../

14 Aluna 7: Um tem o molinete

15 Professora: Um tem o molinete...

16 Aluna 7: E o outro tem uma vara normal.

17 Professora: E o outro tem uma vara normal, uma vara simples. Então quer dizer que aquele que

18 é mais rico que é o governo, que acabaram de dizer tem um molinete e tem... O molinete, ele

19 nos permite o quê? Quem entende de pescaria sabe disso. O que que ele nos permite?

$20 \quad$ I.../

21 Professora: Puxar mais rápido ((repetindo o que os alunos falaram)) e também fazer com que...

22 Aluna 8: Fisgar.

23 Professora: Fisgar. E também tem uma coisa aí de comprimento que vocês, eu não sei se vocês 24 perceberam...

25 Aluna 9: Mais longe, joga mais longe.

26 Professora: Ah é... Quando eu tenho o molinete, eu posso ter mais linha. E aí, observem que a

27 linha do governo... é uma linha maior do que a linha do povo. Por que será? /.../

28 Aluna 10: Mais poder. 
A partir da linha 01, do Excerto 13, que se refere à continuidade do diálogo do Excerto 12, a professora-pesquisadora começou a obter respostas mais formuladas dos alunos, o que indicou mais conhecimento deles a respeito da imagem. Porém, ainda não satisfeita, ela forneceu mais andaimes, indicando o olhar dos discentes para as características dos personagens e dos objetos que eles seguravam. As alunas 07, 08, 09 e 10 descreveram as funções do molinete, e a professora-pesquisadora, em parceria com elas, concluiu que o governo possuía mais recursos, mas, mesmo assim, apropriava-se do produto do trabalho do povo. (linhas 09-30)

Os exemplos transcritos nos excertos 12 e 13 ratificam a essência da teoria de Vygotsky, que reconhece na interação social a melhor forma de adquirir aprendizagens e desenvolvimento. A linguagem é, então, um sistema mediador, fundindo-se com o pensamento, que se torna verbal, dando à linguagem o teor racional no qual reside a compreensão do sentido do texto. (VYGOTSKY, [1934]2001, p. 11)

A diferença estabelecida entre aprendizagem e desenvolvimento condiz com a ideia de mediação da atividade cognitiva defendida por Vygotsky (MORATO, 2002, p. 75), pois $o$ conhecimento não é dado nem adquirido, ele mostrado, acentuado e demonstrado pelo professor e, a partir dessas operações, ele é construído (...) (FRIEDRICH, 2012, p. 114). Quando os estudantes repetem o que a professora diz, reiteram uma afirmação fornecida por ela, continuam um raciocínio, agem como objetos da atividade cognitiva. Mas, quando a continuidade de uma ideia gera novos pensamentos e amplia a compreensão dos alunos, eles passam a ser sujeitos da própria aprendizagem e do próprio desenvolvimento.

É nesse momento que ocorre a clarificação, a experiência estalo ou experiência de eureca. A respeito disso, o aluno $01 \mathrm{fez}$ reflexão, durante o grupo focal, sobre o texto 04 , que segue.

\section{Texto 04 - Charge}

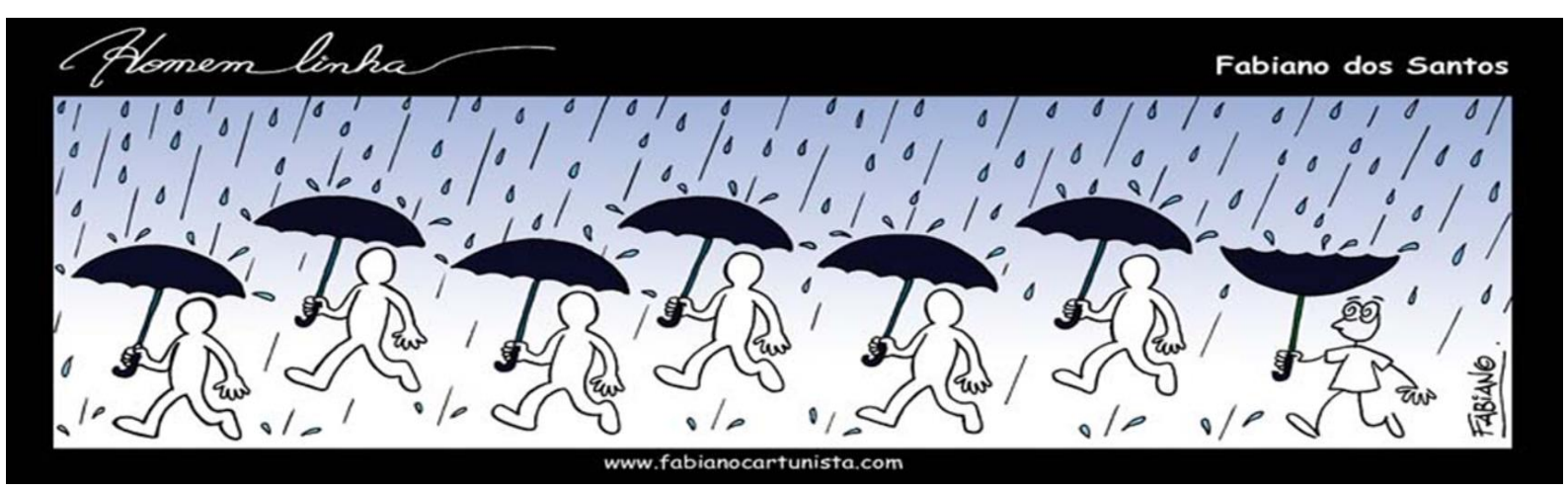

Disponível em: https://cantinholiterariososriosdobrasil.files.wordpress.com/2012/08/fabiano-08-2012.jpg. Acesso em 13/03/2015 
O texto 04 fez parte da atividade escrita 01, aplicada na segunda aula, antes da discussão coletiva com a turma, e permitiu aos alunos construírem reflexões acerca do texto, para que depois elas fossem contrapostas com as dos colegas durante a atividade de socialização da leitura. $\mathrm{O}$ aluno 01 fez o seguinte depoimento no grupo focal:

\section{Excerto 14 - Grupo Focal}

01 Aluno 01: /.../ Foi lá, quando eu olhei aquela charge, que tinha várias pessoas com o 02 chuveiro, com o guarda-chuva, aliás, desculpa, e lá no final tinha.... Até hoje, no outro dia, eu 03 conversando com minha colega, eu até comentei sobre isso. E lá no final tinha uma pessoa 04 com um guarda-chuva, é, ao contrário, né, a ideia pra mim, quando eu vi a figura num 05 primeiro momento, foi que a pessoa tava fazendo aquilo porque, de repente, veio um vento e 06 virou o guarda-chuva dela, entendeu? E só pude perceber isso através do comentário da 07 minha colega do lado, entendeu? Que "olha, apenas um se preocupou em economizar, 08 enquanto centenas de pessoas nem se preocuparam com o que poderia acontecer". Então eu 09 poderia tá direcionando o meu texto escrito de uma outra forma, se eu não tivesse escutado a

10 minha colega do lado falando. Né? Então é interessante, é legal, é divertido.

A interação com a colega, durante a atividade escrita individual, fez com que o aluno 01 mudasse suas ideias a respeito do texto 04. O que, a princípio, esse aluno havia interpretado como uma ventania, responsável por ter virado o guarda-chuva do último personagem, tornou-se postura crítica do personagem da charge diante do problema da crise hídrica. A atividade cognitiva, que poderia ter ficado estagnada no desenvolvimento real do aluno, tornou-se desenvolvimento potencial, pois ampliou a sua capacidade de interpretação ao dialogar com a colega, ampliando a compreensão do texto. A colega também forneceu pistas a ele, por isso, colaborou na construção de andaimes do aluno 01 - o que o levou a escrever o parágrafo, a seguir, referente ao texto 04 .

Figura 14 - Compreensão do texto 04 pelo aluno 01 - atividade escrita 01.

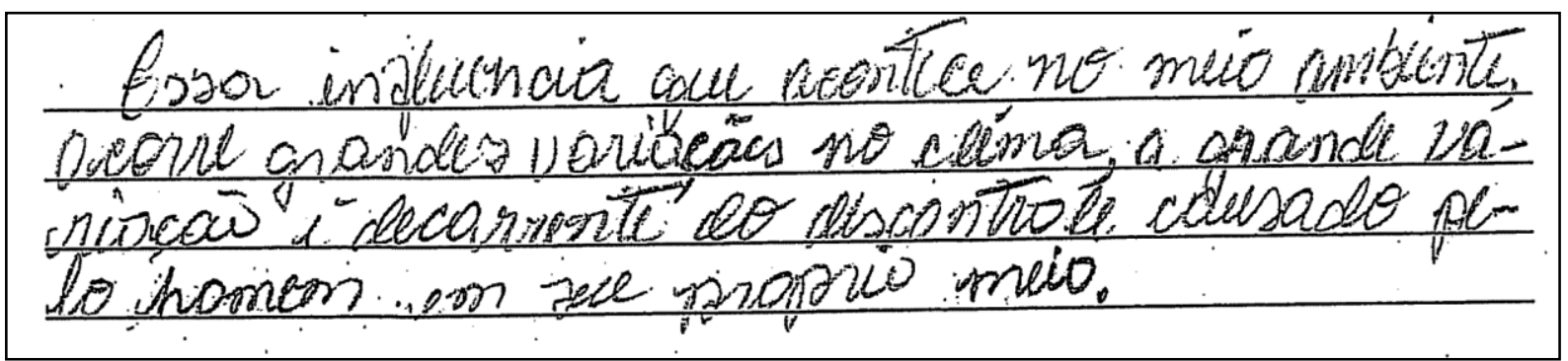

Fonte: textos produzidos pelos colaboradores de pesquisa.

A mediação mostra-se, portanto, condição primordial para interpretação da vida mental dos sujeitos, pois a linguagem natural é polissêmica, sendo que o contexto e as 
relações intersubjetivas representam condições absolutamente indispensáveis para que os processos cognitivos sejam relacionados aos fatos da linguagem. (MORATO, 2002, p. 100). Por meio da relação interativa estabelecida com a colega, o aluno 01 transformou seu modo de compreender o texto 04, optando pela substituição de ponto de vista e constituindo-se sujeito do processo de clarificação.

$\mathrm{O}$ estudo dos frames também constitui estratégia importante para analisar como os interagentes constroem seus conhecimentos diante das situações interativas em que se encontram. Frames (enquadres), na abordagem de Bateson ([1972] 2002), é definido como um conjunto de instruções compreendidas pelos interagentes sobre como deverão compreender a mensagem, ajudando-os a compreender o que se diz ou que se faz por meio da fala. Para Fillmore (1982), os frames constituem molduras, que dizem respeito às hipóteses realizadas pelos interagentes acerca do mundo e do estado das coisas do mundo. Tannen \& Wallat (1987, pp. 206-207) entendem que os enquadres interativos (conhecimentos compartilhados pelos interagentes) interagem com os esquemas de conhecimento (expectativas dos interagentes acerca do que está sendo relatado no contexto interacional), pois eles operam em caminhos similares em todas as interações face a face ${ }^{34}$. (Ibid, p. 215)

A concepção dessas duas autoras revela a amplitude com que os estudos sobre a construção da compreensão textual devem ser guiados. Para Tannen \& Wallat (ibid), a noção de frame envolve tanto as questões interacionais como os processos cognitivos (semânticos), no entanto, essas duas autoras ainda não vislumbram a integração dessas duas concepções de frames nos processos interativos.

A respeito dessa integração dos frames, Morato (2010, p. 95) argumenta a favor de

\footnotetext{
uma noção que, seja qual for a perspectiva teórica que a mobiliza (da Semântica Cognitiva à Sociolinguística Interacional, por exemplo), terá sempre a ver com estruturas de expectativa, isto é, não se trata de algo concebido a priori e nem de forma independente quanto a nossas experiências sócio-culturais; pelo contrário, dependem dos atos de significação e, portanto, das práticas mediadas largamente por linguagem.
}

Por essa razão, este estudo concebe a noção de frame interacional, mesmo reconhecendo a existência do frame conceitual, pois a efetivação do conhecimento acontece quando ao sujeitos interagem entre si, negociando sentidos com vistas ao enquadramento no contexto discursivo do texto.

\footnotetext{
${ }^{34}$ Tradução própria.
} 
Fillmore (1976, p. 25) entende que a linguagem tem tanto frames interacionais como frames cognitivos ou conceituais ${ }^{35}$. Os estudos da etnografia da fala indicam que todas as escolhas linguísticas dos interagentes se referem ao modo como eles se enquadram em determinado contexto (frames interacionais). Porém, antes de se enquadrarem, os interagentes ativam em suas mentes estruturas de expectativas sobre o evento, a partir de seus conhecimentos prévios (frames conceituais).

Foi na interseção dos frames interacionais com os frames conceituais que o aluno 01 construiu o sentido a respeito do texto 04. A priori ele não possuía conhecimentos prévios suficientes para realizar, de modo amplo, inferências acerca da imagem exposta na charge, ou seja, seus enquadres conceituais ou cognitivos permitiram ao aluno inferir que o último personagem teve seu guarda-chuva virado por causa de um vento. Entretanto, por meio da partilha de expectativas com sua colega, esse aluno percebeu que seus esquemas de conhecimento não condiziam com os dela e, por meio da negociação, os interagentes chegaram à conclusão de que o entendimento partilhado pela colega era mais coerente com o texto 04. Esse dado ratifica que a noção de frames deve ser entendida sob a ótica do conhecimento mediado pelas práticas sociais.

\footnotetext{
(...) acreditamos que essas duas esferas do conhecimento - interacional (enquadres interativos) e semântico (esquemas de conhecimento) - inter-relacionadas num continuиm dialético, podem ser articuladas em torno de um postulado interacionista básico já formulado por Vygotsky. (MORATO, 2010, p. 100)
}

Consoante a proposta de Vygotsky, portanto, é necessário focalizar-se na construção de práticas de ensino voltadas para atividades interativas que permitam a correlação entre desenvolvimento e aprendizagem, ao ponto de os dois se intercruzarem.

\subsection{Cognição humana, linguagem e cultura}

Como forma de contextualizar a perspectiva social da cognição humana dentro dos estudos linguísticos, o trabalho de Marcuschi (2007a, p. 33) dialoga com os estudos de Vygotsky e Tomasello. Para Marcuschi (ibid), a cognição, do ponto de vista dos estudos linguísticos, deve estudar os meios de produção e transmissão dos conhecimentos linguisticamente. Para ele, nossas representações são projeções de um mundo elaborado mentalmente na base de experiências não apenas individuais, mas socializadas e constituídas

\footnotetext{
35 Tradução própria.
} 
em discursos (MARCUSCHI, 2007a, p. 40). Entende-se a língua, assim, como uma instituição social, que constrói sentido público para seu uso.

Por isso, não se pode aferir à relação linguagem-mundo um caráter biunívoco, mas configurada por ações sociais e cognitivas conjugadas, o que leva a refutar, neste estudo, a perspectiva da análise dos significados das palavras pelo viés da semântica vericondicional, pois o mundo se apresenta categoricamente, mas não se mostra do mesmo jeito para todas as línguas. Ao contrário disso, a forma de entender o mundo de um grupo social irá influenciar as suas construções linguísticas, ou seja, a significação surge quando se inserem os conhecimentos encapsulados em palavras no contexto de uso. (MARCUSCHI, 2007a, p. 41)

Por isso, torna-se desnecessário buscar a significação em elementos exteriores à língua e à cultura, haja vista que algumas expressões da língua, como a justiça é cega, não se trata de uma descrição dos fatos do mundo exterior (físico), mas de entidades culturais complexíssimas (ibid, p. 41-42). Assim, analisar os aspectos externos da linguagem significa voltar-se para as questões das ações sociais mediadas pela linguagem, e não para dados que possam ser definidos como verdade ou não verdade.

A abordagem sociocognitivista critica, desse modo, a equação linguagem-realidade, propondo uma nova fórmula em que as expressões linguísticas constituam apenas pistas parciais e indeterminadas para a construção do sentido, que passa a ser negociada entre os interagentes nas cenas de atenção conjunta.

A ação conjunta da linguagem e da cognição também é reiterada por Tomasello ([1999]2003, p. 296-297) quando ele apresenta a ontogênese humana pelo seguinte processo: (1) nascimento; (2) identificação com os coespecíficos; (3) atividades de atenção conjunta; (4) aprendizagem por imitação; (5) reprodução da linguagem dos adultos e (6) juízos individuais, decisões, categorizações, analogias e avaliações. Todo desenvolvimento da cognição humana pela linguagem se realiza por meio do compartilhamento dos artefatos culturais entre os interagentes. Entre eles, a linguagem opera efeitos transformadores na cognição humana pelo caráter intersubjetivo dos símbolos linguísticos, por estes serem socialmente compartilhados e pelo caráter perspectivo, pois são interpretados de diversos modos para diferentes propósitos comunicativos. (Ibid, p. 298)

Portanto, é necessário reconhecer o contexto no qual a cognição se processa como forma de compreendê-lo numa abordagem sociocognitiva. Normas, ideologias, crenças, conhecimentos, atitudes, valores e ideologias serão tratados neste trabalho como componentes da cognição social ou das representações sociais. 
A investigação da cognição em abordagem social e cultural deve considerar o papel do self ${ }^{36}$ na percepção do contexto situacional da comunicação, a categorização e a compreensão de que os atores sociais pertencem a um grupo e formam julgamentos e impressões sobre seus integrantes. Além disso, é necessário considerar que os sujeitos produzem uma redução de informações complexas acerca dos atores sociais envolvidos na interação, dando lugar a estereótipos sociais e a preconceitos. Assim, as inferências são realizadas por meio de conhecimentos e crenças dos participantes. (VAN DIJK, 2009, p. 33)

Brown \& Fraser (1979, p. 35) apresentam fluxograma (Figura 15) dos componentes de situação $^{37}$, que delineia muito bem o processo da cognição social. São levados em consideração, no contexto situacional, os elementos iniciais: o que está acontecendo (cena) e com quem está acontecendo (participantes). Dentro da cena estão inseridos cenário (espectadores, tempo, local) e propósitos (tipos de atividade e assunto). A respeito dos participantes, faz-se necessário compreendê-los como sujeitos dotados de características estáveis (personalidade, interesses, aparência física) e temporárias (estado de humor, emoção, atitude), e o modo como se compreendem membros de um grupo social (classe, etnia, idade). Além disso, é preciso considerar como esses participantes se relacionam com os outros membros do grupo social de que fazem parte, incluindo-se as relações interpessoais (gostos e conhecimentos) e as relações de papel e categoria (poder e status social dentro e fora do grupo).

\footnotetext{
${ }^{36}$ A construção do Self, conforme os estudos de Goffman (2009, p. 15), é realizada durante as interações sociais. Esse autor (ibid) afirma que, quando um interagente está com os outros, as suas ações serão calculadas de acordo com as respostas que ele espera dos outros. Assim, o self se refere ao modo como os sujeitos negociam e projetam suas identidades sociais nos grupos dos quais fazem parte.

37 Termo original: components of situation.
} 
Figura $15^{38}$ - Components of a situation

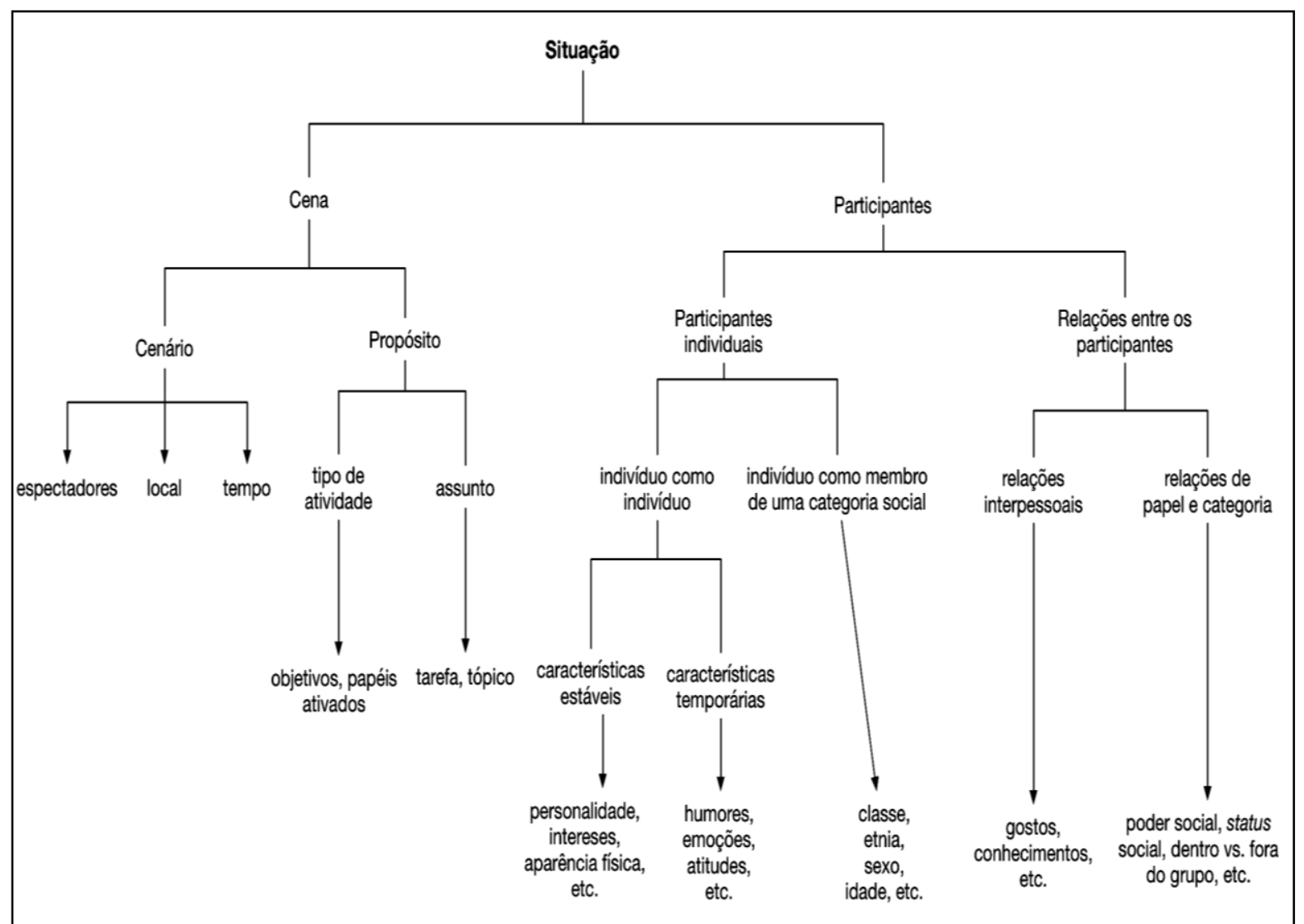

Fonte: Brown \& Fraser (1979, p.35)

Logo, os eventos comunicativos não possuem somente atores sociais e ações, mas também crenças sociais e as maneiras pelas quais elas estão atreladas a crenças pessoais. Ou seja, os modelos de contexto também precisam de um componente "cognitivo" (VAN DIJK, 2009, p. 80-81 - aspas do autor), que está ligado a conhecimentos pessoais e socialmente compartilhados. Assim, as propriedades do discurso são compreendidas, partilhadas e controladas por opiniões baseadas em crenças de grupos e socialmente compartilhadas.

Uma vez que cada participante de um grupo adquire, pela aprendizagem, o conjunto de representações (crenças e ideologias) das gerações anteriores como um acervo de modelos culturais, esse sujeito possui base de dados que seria incapaz de construir sozinho ao longo de sua vida e, além disso, produz mais conhecimentos, que serão transmitidos para gerações futuras. Por isso, o conhecimento, além de constituir realização psicológica, é também uma das maiores realizações sociais. (SALOMÃO, 2005, p. 162)

\footnotetext{
38 Tradução própria.
} 
O compartilhamento dos artefatos culturais é também fenômeno ontogenético e filogenético (WARNEKEN \& TOMASELLO, 2009, p. 468-470) e ocorre por meio da cooperação. As atividades cooperativas são baseadas em intenções compartilhadas, com os interagentes assumindo diferentes papéis direcionados a uma meta comum. Tomasello (2009, p. 08) afirma que os seres humanos são propensos ao altruísmo e à colaboração e que essas suas características corroboram para a cooperação. Por isso, na interação, as pessoas sempre fornecem informações relevantes não para si mesmas, mas para os interlocutores. (Ibid, p. 18)

Tomasello (2009, p. 31) cita o termo gerenciamento de impressão de Erving Goffman para demonstrar o quanto a sociedade impõe às crianças modelos de comportamento que funcionam como um tipo de vigilância, os quais determinam um self público. As crianças, então, identificam-se com os adultos ou com aquilo que os adultos apresentam a elas para que consigam "conviver socialmente", fazendo-as se verem no outro, o que Tomasello (2003, p. 40) identifica pela expressão: he is $m e^{39}$.

Mais uma vez, Tomasello (2009, p. 74-75) defende os princípios ontogenéticos e filogenéticos no que se refere à cooperação dos seres humanos. Consoante com esse autor,

\footnotetext{
as espécies únicas das atividades colaborativas humanas são aquelas que têm objetivos únicos aliados a papéis individuais coordenados pela atenção conjunta e pelas perspectivas individuais (...). As atividades colaborativas concretas que vemos em crianças jovens são bem representativas nas atividades colaborativas do processo da evolução humana ${ }^{40}$. (TOMASELLO, 2009, p. 74-75)
}

Por essa razão, esse teórico (ibid, p. 21 e p. 61) assegura que, se as pessoas não tivessem a tendência natural de ajudarem umas às outras, não conseguiriam sair do chão na história da evolução dos seres humanos, ou seja, não evoluiriam a fim de alcançar o nível em que a espécie humana se encontra. Portanto, as atividades cooperativas partilhadas caracterizam os seres humanos e os diferenciam dos demais primatas.

Nesse viés, as normas e as instituições sociais são definidas por meio da interação social e construídas de modo social e cultural. Quando algumas atividades colaborativas são realizadas por diversas vezes e por diversos membros de uma comunidade; por diferentes indivíduos em diferentes papéis e em diferentes ocasiões; as atividades colaborativas tornamse práticas sociais com estruturas reconhecidas por todos, materializando-se socialmente a ponto de se tornarem artefatos culturais que constituirão os backgrounds dos sujeitos. (Ibid, pp. 90-91)

\footnotetext{
${ }^{39}$ Ele sou eu. (Tradução própria)

40 Tradução própria.
} 
Entretanto, Tomasello (2009, p. 99-100) alerta que a tese sobre tendência dos seres humanos para cooperação não os torna anjos cooperativos, pois eles também se unem para realizarem atos hediondos. Assim, é coerente afirmar que a cooperação dos humanos se estende ao grupo local do qual eles são parte. Esse grupo, em espírito de cooperação, é talvez, ironicamente, uma das principais causas de conflito e sofrimento no mundo de hoje ${ }^{41}$. Não apenas causas de conflitos e sofrimento, como também de lutas e transformações sociais para a melhoria social.

A linguagem é também uma atividade compartilhada (CLARK, 1996; MIRANDA, 2001; WARNEKEN \& TOMASELLO, 2009). Quando os interagentes estão tendo uma conversa, há um jogo dos papéis relacionados ao locutor e ao interlocutor, e cada um deles faz sua parte em relação à meta compartilhada para que eles se compreendam. Por isso, (...) $a$ razão pela qual um falante emprega uma dessas descrições e não outra tem a ver com a sua avaliação de qual combina melhor com os seus objetivos comunicativos e com as necessidades e expectativas comunicativas do ouvinte ${ }^{42}$. (TOMASELLO, [1999]2003, p. 216)

Assim sendo, o falante coopera para que suas intenções comunicativas possam ser compreendidas por quem o ouve, ao passo que o ouvinte também coopera demonstrando boafé na tentativa de compreender o que o falante diz a ele, solicitando clarificações, quando necessário. (WARNEKEN \&TOMASELLO, 2009, p. 470-471)

Todavia, nas atividades realizadas em sala de aula, para geração dos dados desta pesquisa, o texto era o centro das questões interacionais, e a compreensão constituía atividade linguística de construção de sentidos em que o interagente-autor não se encontrava no mesmo cenário que os interagentes-leitores. O texto, assim, representava prática social que precisava ser desvelada por meio da compreensão das intenções do autor, por meio das estratégias discursivas utilizadas por ele. Mesmo assim, os alunos procuravam, a partir das referências/representações sociais que possuíam, construir algum sentido para o texto e compartilhá-lo com a professora-pesquisadora e os demais colegas da turma. No excerto 14, por exemplo, o aluno 01 relatou a necessidade de ele se adequar a uma compreensão mais coerente acerca do sentido do texto 04 , tanto que compartilhou os significados possíveis com a colega que estava ao seu lado, a ponto de perceber que estava equivocado com a interpretação que havia feito a respeito do conteúdo da charge. Isso o motivou a modificar seu

\footnotetext{
41 Tradução própria.
}

${ }^{42}$ Tradução própria. 
texto escrito (Figura 14, p. 92) a fim de adequá-lo a um modelo julgado por ele próprio como a melhor forma de entender o texto.

$\mathrm{Na}$ idade adulta, os alunos já possuem a capacidade e a tendência de se identificarem com seus coespecíficos, de modo a entendê-los como agentes intencionais iguais a eles mesmos, com suas próprias ações, e como agentes mentais iguais a eles mesmos, com seus próprios desejos e crenças (TOMASELLO, 2003, p. 282). Esse pensamento elucida que

\footnotetext{
a cognição adulta moderna do gênero humano é o produto não só de eventos genéticos que ocorreram ao longo de muitos milhões de anos no tempo evolucionário, mas também de eventos culturais que ocorreram ao longo de dezenas de milhares de anos no tempo histórico, e eventos pessoais que ocorreram ao longo de muitas dezenas de milhares de horas no tempo ontogenético. (TOMASELLO, [1999] 2003, pp. 302-303)
}

Portanto, não se trata somente de uma questão de evolução da espécie humana, trata-se disso e de muitos outros fatores ligados à construção evolutiva, histórica e sociocultural da estrutura da cognição humana defendida neste estudo. Dentro dessa perspectiva, a metacognição e a redescrição representacional constituem elementos essenciais da função autorreguladora da cognição, que significa, nos termos de Tomasello ([1999] 2003, p. 270), ensinar a si mesmo. A metacognição se refere ao conhecimento que se tem dos próprios processos ou produtos cognitivos e a tudo que se relaciona a eles (LEFFA, 1996a, p. 46) e à organização desses processos em relação aos objetos cognitivos a que se referem.

Porém, defende-se o entendimento mais sociointeracional da metacognição, no qual ela diz respeito à habilidade de compreender os processos de conhecimento de si mesmo e de outros. (ÁLLAN e SOUZA, 2009, p. 166). A metacognição integrou as atividades de leitura e compreensão textual realizadas durante a geração dos dados. Isso pode ser visto no Excerto 15, no qual a aluna 05, narrou, durante o grupo focal, a situação incômoda na qual se encontrara durante a realização da atividade de compreensão do texto 02 (Charge - Calvin e Haroldo).

Ao realizar a produção textual compreensiva, a aluna revelou, por meio de sua escrita (Figura 16), o incômodo diante da situação de não compreender o texto. 
Figura 16 - Compreensão do texto 02 pela aluna 05 - atividade escrita 01.

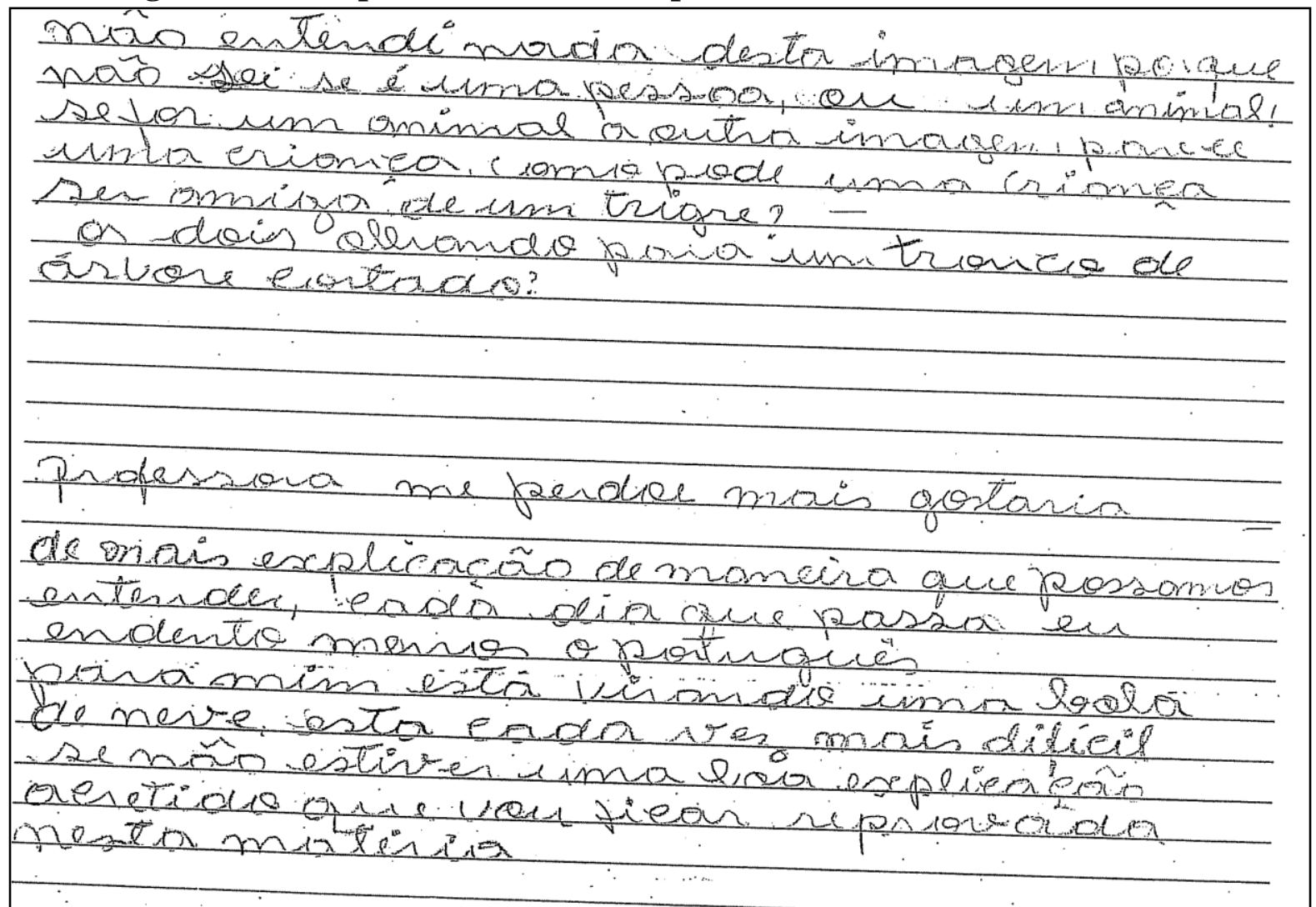

Fonte: textos produzidos pelos colaboradores de pesquisa

\section{Excerto 15 - Grupo Focal}

01 Aluna 05: Me deixou muito confusa ((risos)). Eu não entendi muita coisa não. Aí eu fiquei

02 pensando assim eu não relacionei à imagem. Assim, eu fiquei meio confusa.

03 l...l

04 Professora: Então, a primeira coisa assim que veio à sua mente. Tá e aí, depois, né de eu ter 05 entregue pra vocês. Na aula posterior, eu entreguei, coloquei no quadro os slides e aí a gente. E

06 aí, como é que foi? Aí, depois daquela conversa, como vocês passaram a compreender esse texto?

07 Aluna 05: Eu é... Entendi assim... que eles ficou meio que assustado porque um rastro do ser

08 humano passou por ali, né. Já tem uma árvore cortada, então ele já ficou assim meio que... "agora

09 eles descobriram a gente, né". /.../

Na Figura 16, a aluna 05 evidenciou sua angústia e insatisfação diante do não entendimento do texto, a ponto de deixar uma mensagem para a professora-pesquisadora (linhas 12-21) rogando elucidação de suas dúvidas. Segundo Leffa (1996a, p. 46), a expressão escrita dessa aluna se refere ao processo de metacognição na leitura, a qual trata

(...) do monitoramento da compreensão feito pelo próprio leitor durante o ato da leitura. O leitor, em determinados momentos de sua leitura, volta-se para si mesmo e se concentra não no conteúdo do que está lendo, mas nos processos que conscientemente utiliza para chegar ao conteúdo. A metacognição envolve, portanto, 
(a) a habilidade para monitorar a própria compreensão ("Estou entendendo muito bem o que o autor está dizendo", "Esta parte está mais difícil mas dá para pegar a ideia principal.") e (b) a habilidade para tomar as medidas adequadas quando a compreensão falha. (Ibid, p. 46)

Quando questionada pela professora-pesquisadora, no decorrer do grupo focal (Excerto 15), se a compreensão dos sentidos do texto 02 havia sido ampliada após a discussão coletiva, por meio do diálogo que estabeleceu diálogo entre a professora-pesquisadora e a turma, a aluna 05 respondeu positivamente.

Além disso, em resposta à pergunta da pesquisadora sobre qual(is) atividade(s) proposta(s) durante os encontros mais contribuiu/contribuíram para ampliação da compreensão dos textos lidos, essa mesma aluna respondeu, concordando com as duas outras participantes do grupo focal, que a última atividade, referente ao texto "Fundo do poço" (Anexo II), retirado do site da revista Super Interessante (http://super.abril.com.br/criseagua/ofundodopoco.shtml), foi a que mais contribuiu para o sucesso da construção de sentido textual, conforme a aluna 05 explicita no Excerto 16.

\section{Excerto 16 - Grupo Focal}

01 Aluna 05: Deu pra gente, a gente já tava com a mente mais aberta, né. Então eu, por exemplo, eu 02 consegui desenvolver um texto gigante lá, entendeu. Por causa das explicação e porque a gente já 03 tinha visto antes, né. Então, eu acho que a última foi muito boa.

A expressão mente aberta (linha 01) aponta para ampliação da compreensão textual conquistada pela estudante, por meio de atividades coletivas nas quais a pesquisadora suscitou debates a fim de contribuir para que os alunos fizessem novas reflexões, além daquelas realizadas antes da mediação. Assim, essa aluna revelou ser muito mais fácil escrever sobre aquilo que se possuía referência. Tal percepção pode ser confirmada na Figura 17, que ilustra a produção textual dessa aluna com muito mais propriedade sobre o assunto do que na primeira atividade (Figura 16). 
Figura 17 - Texto da aluna 05 sobre a crise hídrica - atividade escrita 02.

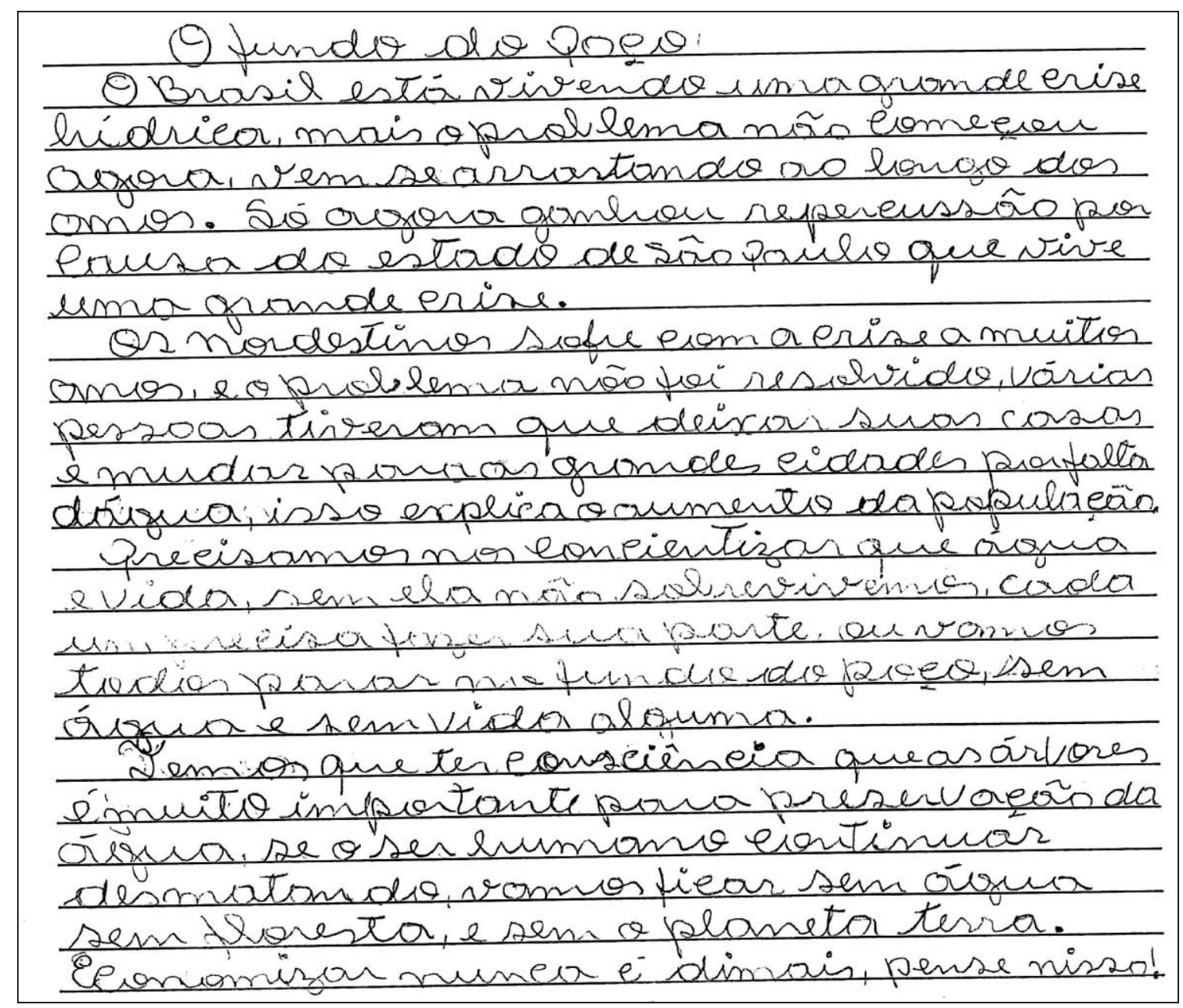

Fonte: textos produzidos pelos colaboradores de pesquisa

Percebe-se, nessa produção da aluna 05, como as interações realizadas anteriormente ampliaram o tratamento do tema pela estudante. Destaca-se o último parágrafo, no qual a aluna afirmou que as árvores são muito importantes para a preservação da água e, se houvesse desmatamento, a humanidade ficaria sem os recursos naturais. As inferências realizadas para a formulação do texto, nessa atividade, foram constituídas pelos discursos compartilhados ao longo dos encontros, pelas leituras individuais, nas quais havia o exercício da metacognição, como também pelas interações alunos/alunos e alunos/professora nas quais dúvidas e opiniões eram postas e discutidas de maneira interativa.

Os dados expostos anteriormente indicam a importância de atividades escritas que permitam processos de metacognição para que os alunos descubram, primeiramente, por si mesmos, quais os sentidos compreendidos ou não compreendidos durante a leitura de um texto, para que, posteriormente, sejam realizadas práticas de interação coletiva entre professor 
e alunos, fazendo-os expressar compreensões diversas e também incompreensões detectadas quando colocados diante do texto.

Desse modo, a metacognição integra o processo de interiorização dos sentidos dos textos, constituindo fenômeno de diálogo intersubjetivo do sujeito consigo mesmo (VYGOTSKY, [1934]2001), acompanhado pelas várias vozes sociais (BAKHTIN, 2009, p. 117), que corroboram na edificação dos processos mentais dos sujeitos e na construção de conhecimentos por meio da autorregulação do discurso, haja vista que esses atores sociais percebem, entendem e categorizam sua própria cognição, que é expressa externamente por meio da linguagem.

\subsection{Reflexões sobre as perspectivas socioculturais da cognição humana}

Por meio das teorias discutidas e dos dados analisados, entende-se que a cognição não ocorre como processo mental dissociado da vida humana, mas como construção coletiva que necessita de aspectos biológicos, sociais, históricos e culturais para acontecer. Assim, este estudo conceberá, durante o desenvolvimento dos demais capítulos, a cognição como processo sociocultural, ou seja, como sociocognição, pelo fato de não haver, aqui, outro modo de entendê-la, senão como esse.

Este trabalho, desse modo, posiciona-se numa perspectiva discursiva, social e cognitiva, em vez de somente cognitiva, pois reconhece a cena comunicativa como condição fundadora dos processos interpretativos (SALOMÃO, 2005, p. 157). Ou seja, os estudantes constroem suas inferências pela conjunção dos processos cognitivos com as interações socioculturais que estabelecem.

O próximo capítulo irá apresentar o percurso metodológico desta pesquisa. Nele serão relatadas as escolhas metodológicas que constituíram o processo de geração e análise dos dados, e as teorias que enquadram este trabalho na pesquisa-ação participativa crítica. 


\section{CAPÍTULO 3}

\section{PARA COMPREENDER O PROCESSO DE PESQUISA: O PERCURSO METODOLÓGICO}

Se não se espera, não se encontrará o inesperado, que é impenetrável e inacessível. (Heráclito de Éfeso)

\subsection{Primeiras palavras}

Este capítulo traçará o percurso metodológico desta pesquisa. Primeiramente, será feita revisão teórica a respeito dos principais entendimentos referentes à orientação metodológica da pesquisa-ação participativa crítica adotada neste trabalho. Além disso, será discutido como essa espécie de investigação qualitativa vem sendo modificada ao longo dos anos de modo a assumir postura mais crítica, atendo-se às mudanças sociais que podem ocorrer no contexto no qual os dados de pesquisa são gerados.

Desse modo, a pesquisa-ação participativa crítica e o grupo focal, técnicas selecionadas para o processo de geração dos dados, serão apresentadas e discutidas, por alinharem-se ao corpo teórico e aos objetivos deste trabalho, que se situa dentro da concepção de língua como ação social e, por essa razão, demanda investigações de caráter qualitativo.

Em seguida, será detalhado o percurso da geração dos dados desta pesquisa. Usa-se o termo geração de dados pela orientação etnográfica adotada nesta investigação. Por essa razão, acredita-se que os dados não estão prontos para serem coletados. Ao contrário, no contexto da interação em sala de aula, os dados são gerados e consolidados nos momentos de interação entre a professora-pesquisadora e os alunos que colaboraram com a pesquisa.

\subsection{Da etnografia à etnografia colaborativa de sala de aula}

O termo etnografia vem do grego ethno - nação, povo, e graphein - escrever, constituindo lógica investigativa utilizada pelas ciências sociais para a geração de dados de pesquisa de caráter qualitativo.

De acordo com Angrosino (2009, p.16), etnografia significa literalmente a descrição de um povo. É uma maneira de estudar pessoas em grupos organizados, que podem ser chamados de comunidade ou sociedade. 
Essa perspectiva começou a ser usada por antropólogos no final do século XIX e início do século XX, por julgarem que as especulações dos filósofos sociais eram inadequadas para a compreensão aprofundada acerca da vida de pessoas reais. Sob influência do império britânico, pesquisadores como Bronislaw Malinowski e A. R. Radcliffe-Brown investigaram áreas que, até então, estavam sob o domínio britânico como as sociedades na África e no Pacífico, nas quais ainda era possível averiguar suas condições de vida, pois ainda eram consideradas sociedades "intocadas", por preservarem suas formas de vida tradicional. Essas pesquisas inauguraram a Antropologia Social. (ANGROSINO, 2009)

Nos Estados Unidos da América, no final do século XIX, Franz Boas desenvolveu estudo com os índios norte-americanos, cujos modos de vida já estavam drasticamente alterados, se não completamente destruídos devido à colonização (ANGROSINO, 2009, p.16). Por isso, nesse caso, o modo de investigação dos antropólogos não poderia estar ligado à observação e à descrição das condições de vida dos índios, mas à reconstrução da história por meio da memória histórica dos sobreviventes. Assim, a antropologia americana passou a ser denominada de Antropologia Cultural.

Malinowski e Boas eram, ambos, defensores da pesquisa de campo e do que, posteriormente, foi concebido como observação participante - uma técnica de pesquisa que coloca o pesquisador em contato direto com a comunidade que está estudando. (ANGROSINO, 2009, p.17)

Assim, para Angrosino (2009), a etnografia constitui metodologia de pesquisa que pretende investigar padrões previsíveis de comportamento de grupo. Baseada em trabalho de campo, é personalizada, multifatorial, de longo prazo, indutiva, dialógica e holística. Também é produto de pesquisa, pois descreve os modos de vida da comunidade por meio de uma narrativa em prosa. (ANGROSINO, 2009, p.34)

A etnografia visa à descrição interpretativa da organização social, das atividades de fala e das representações presentes no discurso construído em contexto específico de pesquisa. Para isso, há vários métodos qualitativos que constituem modos de fazer etnografia.

Bortoni-Ricardo (2008, p.71) enquadra a pesquisa-ação e a pesquisa etnográfica colaborativa na tradição da teoria social crítica, oriunda do marxismo, do neomarxismo e da Escola de Frankfurt. A autora (ibid) trata da etnografia colaborativa, que se relaciona bastante com a pesquisa-ação, pois objetiva não apenas descrever, como no caso da etnografia convencional, mas também promover mudanças no ambiente pesquisado, sendo, ao mesmo tempo, hermenêutica e emancipatória. 
Na pesquisa etnográfica colaborativa, o pesquisador não é um observador passivo que procura entender o outro, que, por sua vez, não tem papel passivo. Ambos são coparticipantes ativos no ato da construção e de transformação do conhecimento. Para tal, a agenda da pesquisa é negociada de modo a atender às necessidades do grupo que vai ser pesquisado. (BORTONI-RICARDO, 2008, p.72)

A pesquisa etnográfica colaborativa pressupõe que o pesquisador realize pesquisa em parceria com profissionais da educação que atuam no contexto pesquisado. $O$ elemento principal da pesquisa-ação colaborativa ou cooperativa, conforme Esteban (2010, p.179), reside na colaboração e no trabalho conjunto entre pesquisadores e educadores, sem excluir outros membros da comunidade educacional. A pesquisa-ação colaborativa deve ter uma equipe formada por, no mínimo, um professor, um pesquisador e um técnico em desenvolvimento (ESTEBAN, 2010, p.180) - o que não constitui a realidade desta pesquisa, que teve como colaboradores somente os alunos da turma do primeiro módulo do curso técnico subsequente em secretariado escolar do IFB. A professora responsável pelo componente curricular Leitura e Produção de Textos cedeu espaço para atuação da professora-pesquisadora, mas não desenvolveu trabalho em parceria direta que envolvesse todo o processo de geração dos dados.

No que tange à pesquisa etnográfica de sala de aula, Bortoni-Ricardo (2008, p.72) salienta que possui objetivo de desvelar o que se encontra na caixa preta da rotina dos ambientes escolares, identificando processos que, por serem rotineiros, tornam-se 'invisíveis' para os atores que dela participam.

Afirmar que esta pesquisa se caracteriza como etnográfica pode levar os leitores a inferirem que se trata de uma etnografia pura, tal qual foi descrita anteriormente por Angrosino (2009). Essa não é a intenção deste estudo, que possui apenas princípios etnográficos - por seu caráter qualitativo - pressupondo pesquisas socialmente situadas e voltadas para a compreensão, a interpretação e a explicação das ações sociais, com vistas à transformação social. Portanto, este estudo possui tão somente orientação etnográfica, pois nele não estão presentes todas as características de uma etnografia pura, tendo em vista que ele não faz análise holística, além de não constituir pesquisa de natureza longitudinal, conforme será explicado mais adiante, no relato da geração de dados. 


\subsection{Pesquisa-ação: origens, conceitos e abordagens}

Segundo vários autores, entre eles Kemmis e McTaggart (2005, p.272), a pesquisaação teve início quando Kurt Lewin, psicólogo social alemão naturalizado americano, publicou resultados de pesquisa-ação sobre programas de ações comunitárias nos Estados Unidos durante os anos 40, levando, com isso, essa metodologia para diversas disciplinas. Logo após Lewin publicar seu trabalho, Stephen Corey iniciou, nos Estados Unidos, a pesquisa-ação em educação. Naquele momento, a pesquisa-ação ainda constituía perspectiva metodológica com pouca aceitação, devido à tradição positivista das universidades americanas.

Kemmis e McTaggart (2005, p.272) também narram a segunda geração da pesquisaação, realizada por pesquisadores do Instituto Tavistock, durante as décadas de 70 e 80 . Houve, nesse interstício, a busca por um paradigma de pesquisa-ação crítica e emancipatória, influenciando a terceira geração, que acolheu pesquisas desenvolvidas na Austrália e na Europa.

A quarta geração da pesquisa-ação emergiu por meio da conexão entre a pesquisa-ação crítico-emancipatória e a pesquisa-ação participativa, desenvolvida no contexto dos movimentos sociais de países em desenvolvimento por nomes como Paulo Freire, Orlando Fals Borda, Rajesh Tandon, Anisur Rahman e Marja-Liisa Swantz; assim como na América do Norte e na Inglaterra, em pesquisas voltadas para a educação de adultos, o letramento e o desenvolvimento de comunidades. (KEMMIS e MCTAGGART, 2005, p.272-273)

Barbier (2007, p.25-36) delineia o percurso da pesquisa-ação pelo mundo e, para ele, a pesquisa-ação já aparecia desde o final do século XIX e início do século XX, com Karl MarX, em sua obra L'enquete ouvière, que já incitava os operários a refletirem sobre suas condições de vida por meio da resposta a um questionário. Também, na França, Frédéric Le Play inaugurava uma sociologia qualitativa (Ibid, p.26) quando desenvolveu monografias sobre orçamentos familiares de operários europeus.

O autor acrescenta à França nomes como Émile Durkheim, Antonie Savoye e Bernard Kalaora, que passaram a considerar os fatos sociais como objeto de estudos, ao passo que as estatísticas tornar-se-iam apenas dados auxiliares indispensáveis à investigação sociológica (BARBIER, 2007, p.26). Segundo ele (ibid), na Inglaterra, a pesquisa-ação voltou-se mais para a formação de técnicos e, na Alemanha, afiliou-se à política, pois pesquisadores como 
Max Weber mantiveram firme a necessidade, ainda de raízes positivistas, de compreender as situações sociais antes de explicá-las.

Nos Estados Unidos da América, Barbier (2007, p.26-27) indica a Escola de Chicago, em concorrência com as universidades de Nova York e da Filadélfia, no desenvolvimento de pesquisas voltadas para os problemas sociais urbanos da primeira metade do século XX, tais como a migração maciça de pessoas vindas do exterior e do Sul em direção ao Norte do país, provocando exclusão social e delinquência juvenil, assim como problemas de sociabilidade. Esses problemas sociais levaram a Escola de Chicago a inspirar outras universidades para formação de técnicos sociais (social workers). As pesquisas, assim, faziam com que pessoas de bairros periféricos participassem dos programas de ajuda social, e, com isso, lideranças comunitárias iam sendo identificadas para atuarem junto à universidade como pessoal qualificado.

Barbier (2007, p.28) esclarece ainda que, para Anne-Marrie Thirion ${ }^{43}$, Jonh Dewey foi o percursor da pesquisa-ação por meio do movimento Mundial da Escola Nova ocorrido após a Primeira Guerra, em função das ideias democráticas escolanovistas e da insistência de Dewey no pragmatismo e no desenvolvimento de hábitos científicos nos educadores e nos educandos.

Por fim, Barbier afirma que se costuma geralmente atribuir a origem da pesquisa-ação a Kurt Lewin, em seus trabalhos durante a Segunda Guerra Mundial. Acerca de Lewin, ele discorre:

\begin{abstract}
Personagem surpreendente, imaginativo e caloroso, esse professor da universidade de Berlin, especialista em Psicologia Gestalt, fugindo do Nazismo desde 1933, chegou aos Estados Unidos onde adotaria a nacionalidade e a mentalidade coletiva. Levin vai desenvolver a Action- Research tentando resolver problemas levantados pelo antissemitismo, pela implantação de usinas nas regiões rurais com uma mão-deobra pouco afeita ao ritmo de trabalho das cidades do norte, como a de Harwood Manufacturing Corporation em 1939. (BARBIER, 2007, p.28 - itálico do autor)
\end{abstract}

As pesquisas desenvolvidas por Lewin sempre se apoiaram na necessidade de fazer com que as pessoas participassem da sua própria mudança de atitude ou de comportamento num sistema interativo (BARBIER, 2007, p.29), por meio de reflexão autocrítica objetiva e de avaliação dos resultados. Assim, a pesquisa-ação se abre para um trabalho social, restabelecendo desse modo, com os trabalhos da Escola de Chicago, pelo exame do comportamento dos bandos de adolescentes, a influência das leis sobre a mudança social (...). (BARBIER, 2007, p.29-30)

\footnotetext{
${ }^{43} \mathrm{Da}$ obra de THIRION, Anne-Marrie: Tendências da pesquisa-ação: exame crítico, publicada na Bélgica, em 1980
} 
Portanto, a pesquisa-ação supõe conversão epistemológica e novas atitudes do pesquisador em Ciências Humanas. Essa mudança diz respeito à transformação da própria visão de mundo do pesquisador, que conforme Barbier (2007, p.32-33), não pode fazer a escolha pela pesquisa-ação de modo irrefletido, haja vista que ele passa a ter riscos institucionais, pois não se trata de uma proposta monodisciplinar, mas interdisciplinar, que combina, conforme o autor, com pesquisadores mais arrojados. Além disso, o pesquisador que adere à pesquisa-ação corre riscos pessoais, porque a pesquisa-ação, na sua intersubjetividade, leva, inevitavelmente o pesquisador para regiões de si mesmo que ele, sem dúvida, não tinha vontade de explorar. (BARBIER, 2007, p.33)

Barbier (2007, p.53, 55 e 57) apresenta a nova pesquisa-ação como o amadurecimento dessa metodologia de pesquisa durante todo o século XX. Ela se configura como etnografia de campo voltada para resolução dos problemas sociais e está muito mais interessada no conhecimento prático do que no conhecimento teórico no contexto educacional. Os dados são gerados de maneira dialógica com os envolvidos na pesquisa, e a interpretação e a análise dos dados são produto de discussões de grupo. A nova pesquisa-ação, assim denominada por Barbier (2007, p.57), será aprofundada e ampliada mais adiante.

Esteban (2010, p.167) também discorre sobre a pesquisa-ação que, segundo ela, está localizada na metodologia de pesquisa orientada à prática educacional. Conforme essa autora (ibid), a finalidade essencial dessa pesquisa não é o acúmulo de conhecimentos sobre $o$ ensino ou a compreensão da realidade, mas, fundamentalmente, contribuir com informações que orientem a tomada de decisões e os processos de mudança com vistas à melhoria das práticas educacionais.

Thiollent (2011, p.20) concebe pesquisa-ação como

\footnotetext{
um tipo de pesquisa social com base empírica que é concebida e realizada em estreita associação com uma ação e com a resolução de um problema coletivo e no qual os pesquisadores e os participantes representativos da situação ou do problema estão envolvidos de modo cooperativo ou participativo. (THIOLLENT, 2011, p.20)
}

Com a pesquisa-ação, objetiva-se alcançar realizações, ações efetivas e transformações ou mudanças no campo social, mas a ação transformadora deve ser colocada, consoante Thiollent (2011, p.49-50), em termos realistas. Não se pode confundir a noção de transformação com mudança social, relacionada, segundo o autor, a categorias estruturais (sistemas sociais, classes), e não a categorias relativas (de pequenos grupos e indivíduos). Esta pesquisa se enquadra na perspectiva das categorias relativas, pois a investigação abarca 
somente a turma do curso técnico em secretariado escolar do IFB, que colaborou no processo de geração dos dados, com vistas à divulgação dos resultados de pesquisa como proposta didática voltada para o trabalho com atividades de leitura em cursos técnicos.

Cohen, Manion \& Morinson (2007, p.297) listam alguns propósitos da pesquisa-ação educacional e Esteban (2010, p.170) os sintetiza. Eles serão apresentados e contrapostos com a realidade desta pesquisa:

(1) É um meio de remediar problemas diagnosticados em situações específicas ou de melhorar, em algum sentido, uma série de circunstâncias. Esta pesquisa surgiu do diagnóstico de que os alunos que ingressavam nos cursos técnicos possuíam grandes déficits de letramento no campo escolar, principalmente no que tange às habilidades de leitura, compreensão textual, escrita e reescrita de textos. Por essa razão, foram focalizadas somente as dificuldades referentes à leitura e à compreensão dos textos.

(2) É um meio de preparação em formação permanente. Esta pesquisa terá como contribuição a construção de uma proposta para o trabalho com atividades de leitura e de compreensão textual para todos os professores que atuam em turmas do ensino técnico. Essa meta constitui uma proposta inicial de formação permanente para docentes de cursos técnicos do IFB.

(3) É um modo de introduzir enfoques novos ou inovadores no ensino e na aprendizagem. A construção desta proposta para condução de atividades de leitura e de compreensão textual objetiva inovar as antigas formas de trabalho com essas atividades. Esses novos enfoques serão delineados por meio das práticas realizadas durante a geração de dados contrapostas com as teorias estudadas neste trabalho.

(4) É um meio para melhorar a comunicação e a relação entre práticos $e$ pesquisadores. A professora-pesquisadora é docente do Instituto Federal de Brasília, embora, no momento da geração de dados, não estivesse atuando como docente da turma na qual os dados foram gerados, pois estava afastada para a realização do curso de doutorado ao qual este trabalho se vincula. Por isso, acredita-se que esta pesquisa constitui elo entre os docentes que estão atuando na educação profissional e os pesquisadores, haja vista que a pesquisadora é também 
docente e conhece a realidade prática da sala de aula em cursos técnicos por já atuar nessa modalidade desde que ingressou no IFB, em 2012.

(5) Possibilita a resolução de problemas na sala de aula. Como já foi apresentado, este trabalho procura auxiliar docentes e alunos a superarem os problemas compreensão textual decorrentes de uma aula de leitura pouco mediada, ou seja, com poucos momentos de interação e de negociação entre professores e alunos com vistas à construção coletiva dos sentidos dos textos e ampliação das inferências.

Esteban (2010, p.170) caracteriza a pesquisa-ação por meio de cinco traços-chave:

(1) envolve a transformação e melhoria de uma realidade educacional ou social;

(2) parte da prática, de problemas práticos;

(3) é uma pesquisa que envolve a colaboração das pessoas;

(4) envolve uma reflexão sistemática da ação;

(5) é realizada pelas pessoas envolvidas na prática da pesquisa. (ESTEBAN, 2010, p.170)

Sobre os aspectos listados, conclui-se que esta pesquisa contempla de maneira efetiva os primeiros quatro tópicos e, de modo relativo, o quinto. Este estudo compromete-se com a melhoria da realidade educacional no contexto pesquisado ao apresentar propostas didáticas para o trabalho com a leitura e com a compreensão textual em cursos técnicos do IFB. Além disso, o que motivou a realização desta pesquisa foi a percepção da pesquisadora e professora do ensino técnico de que alguns alunos possuíam muita dificuldade na construção de inferências durante a leitura de textos, em decorrência do pouco contato com os gêneros textuais trabalhados pelos professores dos cursos técnicos.

Este trabalho envolve a colaboração dos alunos do primeiro módulo do curso técnico em secretariado escolar, que gentilmente concordaram em participar desta pesquisa. Isso pode ser atestado por meio da assinatura do termo de consentimento livre e esclarecido (TCLE) e do termo de cessão de direitos de uso da imagem (TCDUI), aprovados pelo Comitê de Ética da Universidade de Brasília ${ }^{44}$.

Pode-se afirmar que este estudo constitui reflexão sistemática na ação. A pesquisadora ministrou aulas durante o processo de geração de dados e promoveu atividades de compreensão textual, que foram filmadas, transcritas e analisadas após cada encontro com a turma. Essa análise semanal foi norteada por sessões de orientação na Universidade de

\footnotetext{
${ }^{44}$ Os termos citados encontram-se no Anexo I e nos apêndices VI e VII.
} 
Brasília, comandadas pela orientadora do trabalho, que levavam a uma reflexão da prática da semana anterior e à elaboração de atividades para as semanas seguintes, a partir da análise sobre o que foi produtivo e o que precisaria ser aprimorado para que, ao final dos encontros com a turma, fossem reunidos dados suficientes para a construção da proposta didática a que esta pesquisa se destina. Durante a realização das aulas, a pesquisadora guiava sua prática pelas reflexões feitas anteriormente, de modo que ideias novas eram geradas no momento da aula e novamente levadas às sessões de orientação, constituindo um movimento espiral.

O quinto aspecto listado por Esteban (2010) trata da pesquisa-ação realizada pelas pessoas envolvidas na prática pesquisada. Em uma primeira análise, esta pesquisa não se encaixaria nesse parâmetro, pois, como fora afirmado, a professora-pesquisadora não era a professora regente da turma. Embora seja docente da educação básica, técnica e tecnológica e tenha atuado, durante 03 anos, no campus onde a pesquisa foi realizada, no momento da geração dos dados, a pesquisadora estava afastada temporariamente de suas atividades profissionais. A professora de português responsável pela turma colaborou gentilmente com esta pesquisa e cedeu seis aulas para que a pesquisadora assumisse as atividades, tendo como única exigência o trabalho com textos voltados para os temas "Crise Hídrica e Mudanças Climáticas", os quais faziam parte de um projeto interdisciplinar desenvolvido com o professor da disciplina Sociedade e Meio Ambiente.

A partir do momento em que ocorreu o compartilhamento de materiais entre as duas professoras e houve a inserção das aulas no projeto interdisciplinar, considera-se que houve envolvimento no contexto de pesquisa e nas práticas a ele relacionadas.

Todavia, não se pode afirmar que todos os professores envolvidos na prática fizeram parte, de modo integral, da realização desta pesquisa. Mesmo havendo participação da professora-pesquisadora no projeto interdisciplinar, planejando e auxiliando os professores regentes a realizarem o evento de culminância do projeto, os professores regentes não participaram da pesquisa e dos passos de reflexão-ação-reflexão.

Ao fazer uma análise rápida e simplória, poder-se-ia afirmar que a metodologia deste trabalho se inclui totalmente na perspectiva da pesquisa-ação descrita por Esteban (2010), por haver envolvimento e comprometimento com o contexto de pesquisa, gerando introdução de novas estratégias de ensino e de aprendizagem, inovação educacional e mudanças de atitudes por meio de espiral de mudança (ESTEBAN, 2010, p.170-171). Porém, quando se observam todas as características e todos os passos para a realização de uma pesquisa-ação, percebe-se que esta pesquisa não possui, em sua totalidade, todos os traços que fazem dela uma pesquisa- 
ação, em conformidade com o que delinearam Lewin ([1946] 1970), Tripp (2005), Esteban (2010) e Thiollent (2011).

Portanto, a metodologia adotada para a geração dos dados possui muitas características da pesquisa-ação, mas se difere dela no que concerne a dois aspectos: (1) esta pesquisa não reúne como pesquisadores todos aqueles nela envolvidos e (2) este estudo não se enquadra totalmente no modelo espiral de pesquisa-ação, proposto por Lewin (1946) e seguido pelos demais autores, o qual propõe repetição dos passos da pesquisa-ação (figuras 18 e 19) quantas vezes forem necessárias. No entanto, possui o modelo espiral proposto por Kemmis e McTaggart $(2005)^{45}$.

Esteban (2010, p.172) defende a pesquisa-ação como uma espiral sequencial de ciclos constituídos por vários passos e momentos, organizada por processo cíclico, flexível e interativo em todas as etapas. Essas etapas sugerem processo longo de pesquisa - o que não foi possível na geração de dados para este trabalho, tendo em vista os prazos regimentais estabelecidos para sua finalização. Essa autora (ibid, p. 171-172) propõe quatro etapas no percurso da pesquisa-ação:

(1) esclarecer e diagnosticar uma situação problemática para a prática;

(2) formular estratégias de ação para resolver o problema;

(3) pôr em prática e avaliar as estratégias de ação. Comprovar a hipótese;

(4) o resultado leva a uma nova elucidação e ao diagnóstico da situação problemática, iniciando-se, assim, a espiral seguinte da pesquisa-ação. (ESTEBÂN, 2010, p.172-173)

Conforme já esclarecido, dos quatro passos sugeridos por Esteban (2010, p. 172-173), o percurso da geração de dados desta pesquisa comprova que os três primeiros foram realizados.

Por sua vez, Lewin ([1946] 1970, p.03-04), ao apresentar o percurso espiral da pesquisa-ação, estabelece que

o primeiro passo, então, é examinar a ideia cuidadosamente à luz dos recursos disponíveis. Amiúde, torna-se necessária maior averiguação dos fatos. Se este primeiro período do planejamento é bem-sucedido, surgem dois itens: a saber, um 'plano global' de como atingir o objetivo e, em segundo lugar, uma decisão quanto ao primeiro passo da ação. (...) O período seguinte é executar o primeiro passo do plano global. (LEWIN, 1946, p.03-04)

\footnotetext{
${ }^{45}$ Esse modelo será apresentado no item 3.3.2.
} 
Após a primeira execução, Lewin ([1946] 1970) propõe averiguação dos fatos, que possui quatro funções: a primeira é avaliar a ação — se o que foi atingido está acima ou abaixo da expectativa; a segunda é proporcionar aos participantes oportunidade de aprender, de adquirir a compreensão do poder ou da fraqueza de certos recursos e técnicas de ação; a terceira é a construção de bases para o planejamento correto do próximo passo; e a quarta é a modificação do 'plano global'. (LEWIN, [1946] 1970, p.03).

Assim, esse autor (ibid) elenca o passo seguinte que deve possuir o ciclo: planejamento, execução e averiguação dos fatos, formando uma espiral a ser repetida diversas vezes com vistas ao aprimoramento dos grupos (Figura 18) ${ }^{46}$.

Figura 18 - Passos da pesquisa-ação

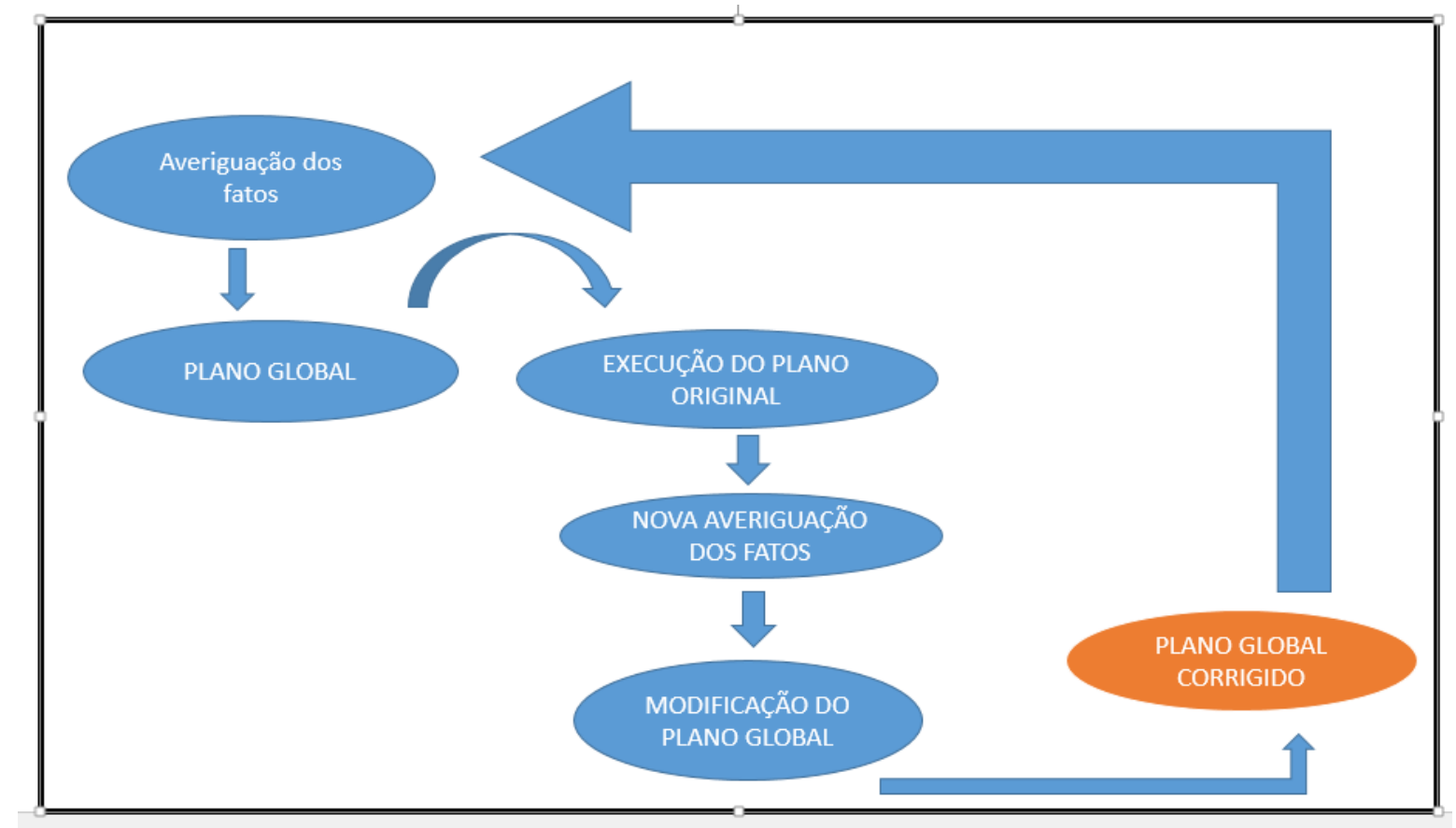

Fonte: Lewin (1946, p.03-04).

Tripp (2005, p.445-446), utilizando o modelo introduzido por Lewin ([1946] 1970), propõe esquema de ciclo para o que ele nomeia de investigação-ação. Para Tripp (2005, p.445-446), a pesquisa-ação é uma das várias modalidades da investigação-ação, que constitui

um termo genérico para qualquer processo que siga um ciclo no qual se aprimora a prática pela oscilação sistemática entre agir no campo da prática e investigar a respeito dela. Planeja-se, implementa-se, descreve-se e avalia-se uma mudança para

\footnotetext{
${ }^{46}$ Esquema produzido pela autora, a partir do texto Problemas de dinâmica de grupo, de Lewin, datado de 1946.
} 
a melhora de sua prática, aprendendo mais, no correr do processo, tanto a respeito da prática quanto da própria investigação. (TRIPP, 2005, p.445-446)

Assim, esse autor propõe um ciclo (Figura 19) que demonstra a natureza espiral das pesquisas que tenham como paradigma metodológico a investigação-ação.

Figura 19 - Representação do ciclo básico da investigação-ação em quatro fases

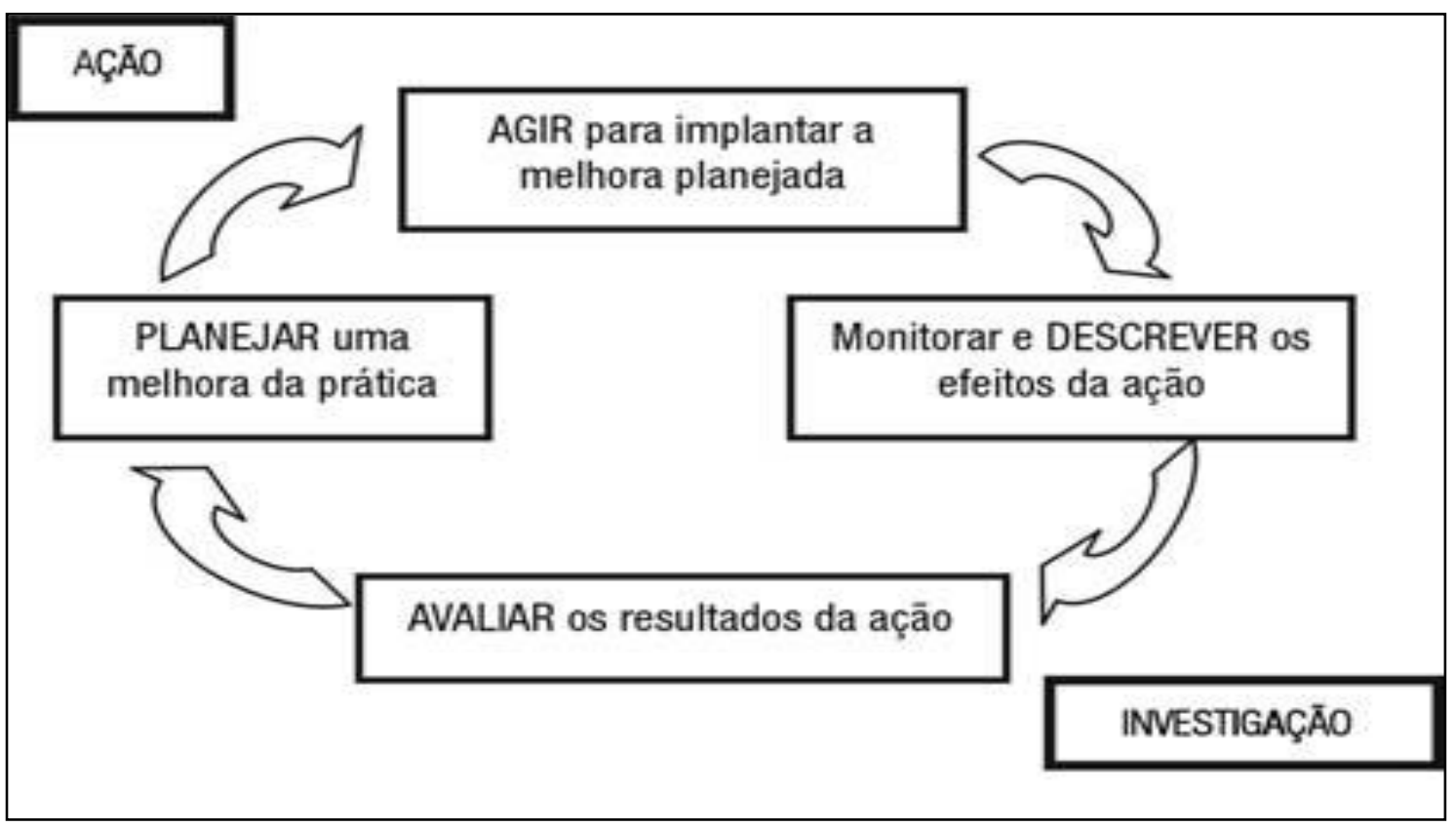

Fonte: Tripp (2005, p.446)

Nesse contexto, esta pesquisa se insere nas quatro fases da espiral que foi proposta por Tripp (2005), com inspiração no modelo proposto por Lewin, em 1946. Porém, esse processo não se repetiu por diversas vezes, haja vista que a pesquisadora se inseriu no contexto educacional por curto espaço de tempo, o que correspondeu a seis encontros cedidos pela professora regente da turma após negociação com a professora-pesquisadora.

Tripp (2005) complementa que tipos diversos de investigação-ação tendem a utilizar processos diferentes em cada etapa e obter resultados diferentes que provavelmente serão relatados de modos diferentes para públicos diferentes (ibid, p.446). Essa característica enquadra esta pesquisa como uma das diversas possibilidades de investigação-ação, pois ela possui algumas características da pesquisa-ação.

Esse autor (2005, p.447) esboça tabela com algumas características da pesquisa-ação. São elas: 
Tabela 1 - Características da pesquisa-ação.

\begin{tabular}{|c|l|l|l|}
\hline Linha & \multicolumn{1}{|c|}{ Prática Rotineira } & \multicolumn{1}{|c|}{ Pesquisa-ação } & \multicolumn{1}{c|}{ Pesquisa Científica } \\
\hline $\mathbf{1}$ & HABITUAL & INOVADORA & ORIGINAL/FINANCIADA \\
\hline $\mathbf{2}$ & REPETIDA & CONTÍNUA & OCASIONAL \\
\hline $\mathbf{3}$ & REATIVA CONTINGÊNCIA & PROATIVA & METODOLOGICAMENTE \\
\hline $\mathbf{4}$ & INDIVIDUAL & PARTICIPATIVA & COLABORATIVA/COLEGIADA \\
\hline $\mathbf{5}$ & NATURALISTA & INTERVENCIONISTA & EXPERIMENTAL \\
\hline $\mathbf{6}$ & NÃO QUESTIONADA & PROBLEMATIZADA & CONTRATUAL (NEGOCIADA) \\
\hline $\mathbf{7}$ & COM BASE NA & DELIBERADA & DISCUTIDA \\
\hline $\mathbf{8}$ & NÃO ARTICULADA & DOCUMENTADA & REVISADA PELOS PARES \\
\hline $\mathbf{9}$ & PRAGMÁTICA & COMPREENDIDA & EXPLICADA/TEORIZADA \\
\hline $\mathbf{1 0}$ & ESPECÍFICA NO CONTEXTO & & GENERALIZADA \\
\hline $\mathbf{1 1}$ & PRIVADA & DISSEMINADA & PUBLICADA \\
\hline & & Fonte: Tripp (2005, p.447). & \\
\hline
\end{tabular}

Ao elencar essas características, Tripp (2005) compara a pesquisa-ação com a prática rotineira e com a pesquisa científica, colocando a pesquisa-ação no meio desse continuum, que, para ele, revela a contradição existente entre prática rotineira e pesquisa-científica, tratando essas duas modalidades não como categorias puras, mas como oposições mistas.

A pesquisa-ação está, assim, em linha bastante tênue entre a prática rotineira escolar, que, no contexto deste estudo, corresponde às aulas dos cursos técnicos que envolvem leitura e produção de textos, e a pesquisa científica, a qual pretende estudar a ação realizada para propor melhorias no contexto escolar supracitado.

Portanto, o paradigma metodológico deste estudo não pode ser configurado unicamente como o de uma pesquisa-ação, mesmo tendo apresentado algumas de suas características durante o percurso da geração de dados, pois houve a triangulação planejamento, execução e averiguação dos dados, conforme proposto, primeiramente, por Lewin ([1946] 1970) e, depois, por outros autores já citados no trabalho.

Assim, buscou-se determinada técnica de pesquisa-ação que dialogasse com a realidade deste estudo, pois a pesquisadora, mesmo ministrando as aulas e seguindo o processo de triangulação, não se encontrava diretamente vinculada ao contexto de pesquisa, mas atuou como agente desse processo, deixando esse status claro para todos os colaboradores envolvidos.

Por isso, fez-se necessário atribuir a este trabalho metodologia que se adequasse ao grau de envolvimento estabelecido com os colaboradores e à perspectiva crítica em que este 
estudo está alicerçado pelo grande comprometimento com a transformação no contexto pesquisado. Portanto, o percurso metodológico traçado nesta pesquisa se relaciona à proposta de pesquisa-ação participativa crítica, conforme as postulações de Kemmis e McTaggart (2005), que serão discutidas no subitem 3.3.2.

\subsection{Convergência da pesquisa participativa com a pesquisa-ação}

\subsubsection{A Pesquisa Participativa}

Conforme Esteban (2010, p.178-179), a pesquisa participativa surgiu na América Latina, na década de 60, em contexto de conscientização e luta de muitos grupos populares, em decorrência da urgência de transformações sociais e políticas nesses países durante esse período. Nesse contexto, a comunidade é convocada a analisar a própria realidade para promover a mudança social que será vivenciada por todos os participantes da pesquisa.

O objetivo primordial da pesquisa participativa é a tomada de consciência da comunidade, e não as contribuições de tipo acadêmico. Trata-se de uma pesquisa que se realiza em âmbitos relativamente pequenos (bairro, aldeia, comarca), cujos agentes são grupos menos favorecidos que se envolvem em um processo educacional, pois pressupõe participação na pesquisa por meio de uma discussão permanente, dialógica, entre iguais, tratando-se, assim, de uma aprendizagem por experiência. Além disso, nessa abordagem de pesquisa, não pode haver neutralidade, pois o pesquisador deve comprometer-se com o grupo de forma ativa. (ESTEBAN, 2010, p.179)

Fica claro, após tudo que foi delineado, que esta pesquisa não se enquadra unicamente na noção de pesquisa participativa. Ainda que o grupo pesquisado fosse formado por alunos inseridos em um contexto social popular, de educação profissional voltada para jovens e adultos, e que a pesquisadora tenha se comprometido com o grupo de modo a compartilhar com os professores os resultados da pesquisa como forma de proposta didática para as práticas de leitura em sala de aula, esta pesquisa não possui todo o envolvimento necessário com as lutas sociais que a pesquisa participativa, em suas origens, pressupunha.

Além disso, de acordo com Esteban (2010, p.179), na pesquisa participativa, $a$ pesquisa e a ação interagem continuamente. Nesse ponto, essa proposta muito se assemelha à pesquisa-ação, conforme foi conceituada neste capítulo. Porém, a autora (ibid) acrescenta que, 
para a pesquisa-participativa, a ação é fonte de conhecimentos, e a pesquisa, uma ação transformadora. Sobre isso, há algumas discordâncias no que se refere a este trabalho.

Entende-se que a pesquisa constitui fonte de conhecimentos, tanto na abordagem quantitativa, baseada em dados estatísticos, como na qualitativa. Mas é preciso destacar que os conhecimentos começam a ser construídos por meio das pesquisas bibliográficas realizadas pelo pesquisador e contrapostas com os dados gerados. Isso leva à produção de conhecimentos não somente pela ação, mas pelo diálogo com as teorias discutidas neste estudo, que são reafirmadas e transformadas por meio da interpretação e da análise dos dados.

Nessa perspectiva, Thiollent (2011, p.21) defende que toda pesquisa-ação tem cunho participativo, pois é a participação das pessoas envolvidas no problema que delineia a investigação. Todavia, o autor (ibid) estabelece diferença entre a pesquisa participante e a pesquisa-ação. Para ele (ibid, p. 21), a pesquisa participante não é uma pesquisa-ação, pois é, em alguns casos, um tipo de pesquisa baseado numa metodologia de observação participante na qual os pesquisadores estabelecem relações comunicativas com pessoas e grupos (...) com a intenção de serem melhor aceitos.

A realidade desta pesquisa diverge dessa afirmação de Thiollent (ibid), pois a pesquisadora atuou como agente e também como observadora. Ao mesmo tempo em que planejava, ministrava as aulas e interagia com os alunos, atuou como pesquisadora filmando os seis encontros, além do grupo focal, transcrevendo-os e analisando-os, haja vista que a proposta da pesquisa era a de investigar como algumas atividades voltadas para a leitura, bem como sua condução, contribuiriam para o desenvolvimento das habilidades de leitura dos alunos participantes, tornando necessária a atuação da pesquisadora como professora regente das aulas.

No curso das interações gravadas, a pesquisadora era a professora, e os alunos estavam conscientes de que a aula da qual eles participavam se tratava também de uma pesquisa. No primeiro encontro e em meados do segundo, o caráter da pesquisa ainda estava muito presente, mas as demais aulas foram fluindo gradativamente e a presença da câmera de vídeo foi-se tornando cada vez mais natural para os colaboradores. Por isso, a interação com os alunos durante as aulas levou a professora-pesquisadora a conhecer boa parte da turma de maneira natural, o que acarretou a sua aceitação, por esta se incluir no processo de ensino e de aprendizagem dos alunos durante esse período.

Assim como Thiollent (2011), Demo (1995) não julga pesquisa-ação e pesquisa participativa como metodologias diferentes, pois o compromisso com a prática é o mesmo em 
ambas. Demo (1995, p.231) destaca o caráter político das pesquisas participativas, que, segundo ele, não podem ser consideradas mera ação social. Além disso, o autor (ibid) afirma que o homem é animal político intrinsecamente e que todas as suas ações guardam contexto político maior ou menor. Esse autor (ibid) enquadra a pesquisa participativa como uma proposta de mudança às abordagens de cunho empirista e positivista, que não atingem relevância social para as camadas populares necessitadas de mudança social. Percebe-se em Demo (1995) a mesma perspectiva adotada por Esteban (2010), ao inserir a pesquisa participativa na agenda de estudos relacionados às camadas populares e à emancipação destas.

\subsubsection{A pesquisa-ação participativa crítica}

Tripp (2005), assim como Thiolent (2011), assegura que toda pesquisa-ação é participativa, pois nela estão envolvidos participantes atingidos pela mudança a que a pesquisa-ação se propõe. Além disso, Tripp (2005) mostra que alguns autores como Carr e Kemmis [(1986) 2004] defendem a pesquisa-ação como processo coletivo muito mais amplo e com consequências políticas.

Conforme as discussões apresentadas, a pesquisa participativa, da forma como foi concebida, e a pesquisa-ação, com todas as características e todas as etapas propostas pelos autores citados, por mais que dialoguem com a proposta da presente pesquisa, não a contemplam por inteiro. Para a pesquisa-participativa, é preciso haver compromisso político com mudanças sociais, e a presente pesquisa assume tal comprimisso, porém, a professorapesquisadora não escolheu o tema trabalhado nas atividades de sala de aula a partir de discussão prévia com o grupo pesquisado para propor estudo sobre o processamento das inferências nas atividades de compreensão textual, mas apenas aderiu ao tema "Crise Hídrica”, que já havia sido escolhido pela professora regente da turma.

Como forma de fornecer a este estudo posicionamento metodológico condizente com o processo de geração de dados, serão abordados agora argumentos teóricos que melhor se enquadram com a realidade desta pesquisa. Eles foram propostos por Kemmis e McTaggart (2005, p.272-273) e ampliam as perspectivas da pesquisa-ação. Esses autores (ibid) elencam algumas metodologias que podem ser consideradas. Entre elas, encontra-se a pesquisa participativa, discutida anteriormente, muito voltada para pesquisas sociais comprometidas com a transformação social dos países de terceiro mundo, opondo-se, assim, ao modus operandi das pesquisas tradicionais. 
Kemmis e McTaggart (2005, p.273) apresentam, ainda, a pesquisa-ação crítica, também ligada aos estudos sociais, mas que possui comprometimento social por reunir ampla análise sobre temas voltados à educação. Essa modalidade de pesquisa emergiu a partir da insatisfação com a pesquisa-ação de sala de aula, que não possuía visão ampla da educação como mudança social.

Os autores (2005) apresentam as várias modalidades de pesquisa-ação, que foram se delineando com o tempo, a partir das necessidades e das realidades nas quais elas eram desenvolvidas. Todas essas modalidades de pesquisa-ação possuem características muito próximas, tornando-se possível observar que elas surgiram de acordo com a realidade do contexto pesquisado e com as necessidades de transformação social com que cada pesquisa se compromete.

Por essa razão, Kemmis e Mctaggart (2005, p.276) apresentam a urgência de se ter uma pesquisa-ação participativa crítica. Segundo eles (ibid), o ressurgimento da pesquisaação ocorreu na década de 90, sob influência de pesquisadores norte-americanos, com inserção de teorias de crítica à modernidade relacionadas ao capitalismo, ao neocapitalismo e ao pós-capitalismo, e aos sistemas sociais. Assim, a distribuição das diversas modalidades da pesquisa-ação pelo mundo a tornou melhor compreendida, havendo a necessidade de um tipo de pesquisa que englobasse todas as outras e que atendesse às necessidades do mundo atual com o objetivo de

fornecer um quadro de referência para a compreensão e a crítica de si mesmo e de seus antecessores. Seu objetivo é oferecer uma forma de trabalho que trate o desenfreado individualismo, o desencanto, e o predomínio da razão instrumental ${ }^{47}$. (KEMMIS e McTAGGART, 2005, p.276)

Diante dessas metas, a pesquisa-ação participativa crítica criou caminho para reinterpretar a pesquisa-ação, desenvolvendo-se na prática, na teoria e também pedagogicamente ao longo do tempo. Kemmis e McTaggart (2005, p.276) descrevem as etapas da pesquisa-ação participativa crítica, as quais ocorrem de modo espiral, como

- planejamento de uma mudança;

- ação e observação das consequências da mudança;

- reflexão dos processos e consequências;

- replanejamento;

- ação e observação novamente;

- refletir novamente e assim por diante... (KEMMIS e McTAGGART, 2005, p.276)

47 Tradução própria. 
Este esquema (Figura 20) muito se assemelha àqueles propostos por Lewin ([1946] 1970) e Tripp (2005), mas possui o seguinte diferencial: observar a ação e refletir sobre ela. Mesmo que os esquemas anteriormente propostos possuíssem a perspectiva da reflexão (em Lewin havia a averiguação da ação e, em Tripp, monitoramento e descrição), eles não eram nomeados desse modo.

Figura 20 - Espiral da pesquisa-ação.

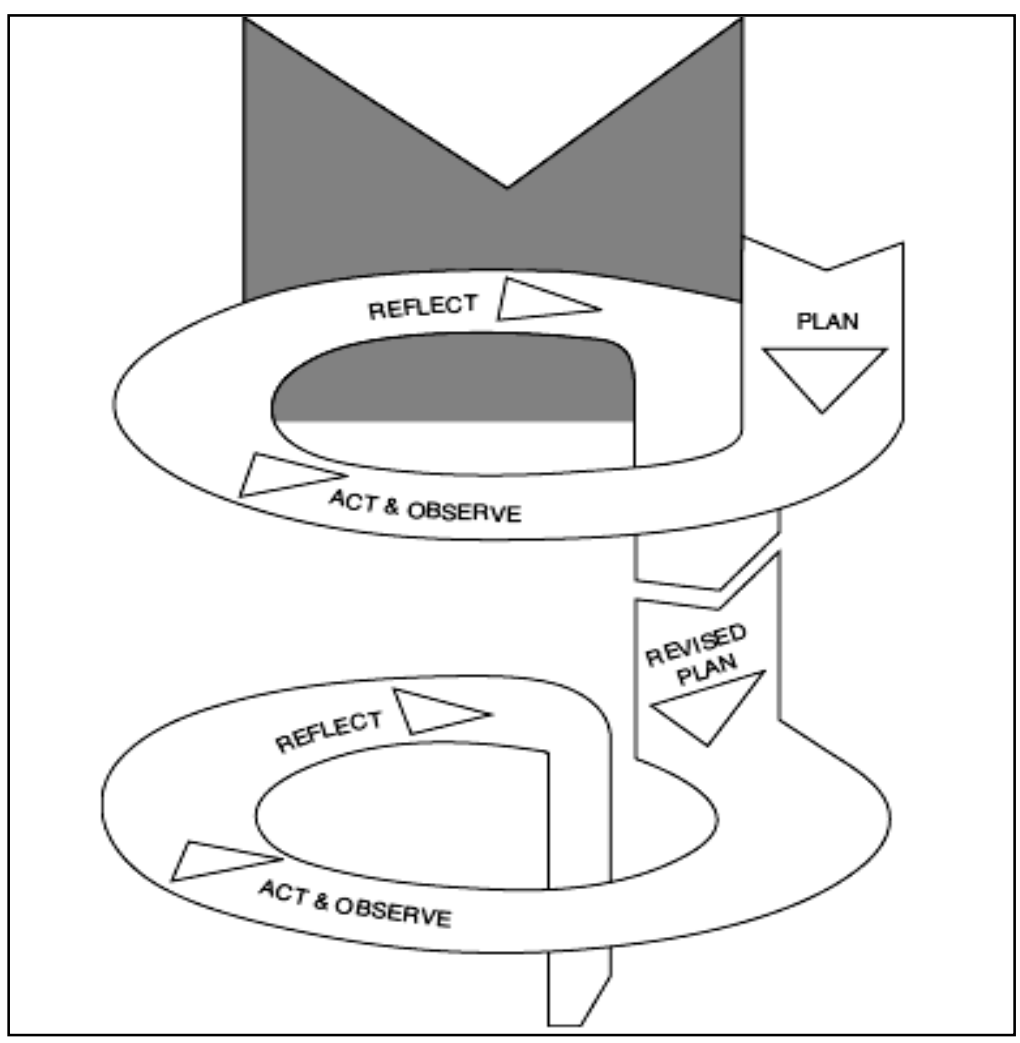

Fonte: Kemmis \& McTaggart (2005, p. 278)

É claro que, nas propostas espirais anteriores, havia pressupostos de reflexão, mas, na proposta de Kemmis \& McTaggart (2005), a observação é inserida na perspectiva da pesquisa-ação participativa crítica como etapa de grande importância, pois é realizada no momento da ação. Assim, a pesquisadora deixa de ser apenas a professora que ministra aulas com atividades de leitura e se torna a professora-pesquisadora que conduz a aula e observa as ações sociais que propõem aos estudantes novas perspectivas de reflexão sobre determinado assunto discutido, com vistas à transformação da realidade.

Para Kemmis \& McTaggart (2005, p.277), esses estágios se sobrepõem e o planejamento inicial logo se torna obsoleto, devido ao aprendizado com a experiência. Portanto, esse processo deve ser fluido, aberto e receptivo. Por isso, o critério de sucesso não depende de que os participantes sigam à risca todos os passos da metodologia proposta, pois o 
que importa é o sentimento forte e autêntico do desenvolvimento e evolução de suas práticas, a compreensão delas e da situação nas quais estão inseridas. (KEMMIS \& McTAGGART, 2005, p.277)

Portanto, a pesquisa-ação participativa constitui processo social e educacional. Os sujeitos envolvidos nessa pesquisa se comprometem com a prática social, pois seu objetivo é o estudo, o reenquadre e a reconstrução das práticas sociais.

Ela envolve a investigação de práticas reais, e não de práticas abstratas. Além disso, compromete-se com a compreensão de práticas materiais, concretas e particulares, com pessoas específicas e em contextos particulares (KEMMIS e McTAGGART, 2005, p.277), o que não impede de a pesquisa-ação participativa crítica preocupar-se em investigar práticas mais genéricas e abstratas, ainda que o foco principal dessa modalidade de pesquisa seja a investigação contextualmente situada.

Acerca da relação entre pesquisadores e colaboradores de pesquisa, os referidos autores (ibid) argumentam que essas diferentes modalidades para o estudo da prática envolvem diferentes tipos de relações entre o pesquisador e os pesquisados e defendem uma perspectiva na qual pesquisadores e colaboradores se tornam participantes da pesquisa, tendo o pesquisador que assumir duplo papel social: de participante, pois não pode se distanciar do grupo, e de pesquisador, que precisa investigar sua prática.

\footnotetext{
Essencialmente, nós argumentamos que as abordagens "objetivas" tendem a ver a prática a partir da perspectiva de um forasteiro na terceira pessoa; que as abordagens "subjetivas" tendem a ver a prática na perspectiva de um insider, na segunda pessoa; e que a perspectiva dialético-reflexiva da ciência social crítica tende a ver a prática a partir da perspectiva do grupo, cujas atividades interligadas dos membros constituam e reconstituam suas próprias práticas sociais (primeira pessoa do plural). Esta última perspectiva sobre prática é a única feita pelo participante-pesquisador na pesquisa-ação participativa ${ }^{48}$. (KEMMIS e McTAGGART, 2005, p.289)
}

Assim, nessa perspectiva, não convém que o paradigma do pesquisador seja o de observador - como preconizam os estudos mais objetivos. É preciso que o pesquisador se aproxime do seu grupo não como aquele que o invade (insider) para realizar a pesquisa, como já criticado por Thiollent $(2011$, p.21), quando este se refere à pesquisa participante. É necessário que o pesquisador faça parte do grupo, fazendo com que sua prática esteja envolvida na rotina do grupo pesquisado.

Argumenta-se, então, que a metodologia para a geração dos dados deste trabalho segue a metodologia da pesquisa-ação na perspectiva participativo-crítica, proposta por Kemmis e

\footnotetext{
48 Tradução própria.
} 
Mctaggart (2005), pois possui viés dialético-reflexivo próprio de pesquisas voltadas para a ciência social crítica, que se compromete, além da apresentação dos dados para comunidade científica, com a transformação da realidade investigada.

A pesquisadora, nas primeiras aulas, agia como uma "pessoa externa" que se inseriu na turma para realizar a geração dos dados, mas, no decorrer do tempo, as aulas foram acontecendo do modo como os alunos estavam habituados, sem fugir da rotina, a ponto de eles se acostumarem com as aulas, que foram ministradas até o sexto encontro, todas as sextas-feiras, no primeiro horário ${ }^{49}$.

Todas as práticas assumidas, desde o primeiro encontro, apontaram para a realização de pesquisa na perspectiva êmica ${ }^{50}$, na qual os colaboradores possuíam ciência e consciência de que aquela seria uma pesquisa de doutorado da professora do Instituto Federal de Brasília e que tinha por objetivo melhorar as atividades de leitura propostas pelos demais professores. Registre-se que os alunos-colaboradores sinalizaram interesse e satisfação com o trabalho voltado para práticas de leitura nessa perspectiva. Eles, ao mesmo tempo que foram colaboradores de pesquisa, foram agentes e protagonistas do processo de geração de dados (vide item 3.4). Os alunos, durante a realização do grupo focal ${ }^{51}$, revelaram reconhecer a importância de pesquisas desse tipo para a melhoria das atividades de leitura conduzidas pelos professores.

\subsection{Grupo Focal: a voz ativa dos colaboradores de pesquisa}

O grupo focal foi inserido no processo de geração dos dados para esta pesquisa, por esta possuir perspectiva êmica, na qual o paradigma do pesquisador não pode ser centrado em única ótica do estudo. A constituição do grupo focal oferece voz aos colaboradores de pesquisa para que eles exressem como a pesquisa contribuiu para a melhoria da compreensão leitora deles e como a prática de mediação utilizada pela professora-pesquisadora facilitou a construção de inferências e a ampliação das suas referências culturais.

Para Morgan (1977), o grupo focal constitui técnica de pesquisa que coleta dados por meio das interações grupais através da discussão de temática sugerida pelo pesquisador. Como

\footnotetext{
${ }^{49}$ Para o sexto encontro, houve um intervalo de uma semana, em virtude da solicitação feita pela professora regente, que precisava se encontrar com a turma na sexta-feira subsequente ao quinto encontro devido a uma atividade externa, que envolvia todos os alunos do campus.

${ }^{50} \mathrm{Na}$ perspectiva êmica de pesquisa, o pesquisador não interpreta os dados exclusivamente sob o seu ponto de vista, mas, principalmente, sob o ponto de vista dos colaboradores de pesquisa.

${ }^{51}$ Os detalhes serão apresentados no capítulo 05, item 5.3.
} 
técnica, ocupa uma posição intermediária entre a observação participante e as entrevistas em profundidade. (GONDIM, 2003, p.151)

Segundo Barbour (2009, p.44), os grupos focais encorajam e dão aos colaboradores oportunidade para falarem sobre questões normalmente não abordadas durante a geração de dados, principalmente, se os grupos forem convocados para refletir sobre algum atributo ou experiência.

Assim, a professora-pesquisadora agiu de modo que pudesse assumir, no momento da gravação, o papel de moderadora da discussão. Nesse grupo focal, os colaboradores foram encorajados a conversarem entre si acerca dos tópicos propostos pela pesquisadora (vide 3.5). Sobre isso, Barbour (2009, p.21) explicita que o estímulo ativo à interação do grupo está relacionado, obviamente, a conduzir a discussão do grupo focal e a garantir que os participantes conversem entre si em vez de somente interagir com o pesquisador ou "moderador".

Portanto, o pesquisador precisa desempenhar, durante o grupo focal, o papel de moderador, que delineia e estimula a discussão, evitando dar o seu ponto de vista e usar termos muito técnicos para os tópicos de discussão.

Conforme Krueger e Casey (2015, p.06), o grupo focal, geralmente,

(1) é um grupo pequeno composto de 05 a 08 componentes, mas pode variar entre 04 e 12 pessoas. Ao exceder o número de doze pessoas, conforme os autores, pode haver fragmentação do grupo;

(2) deve ser composto por colaboradores que possuam características em comum determinadas previamente pelo pesquisador conforme os objetivos do estudo;

(3) precisa fornecer dados qualitativos ao estudo a que se vincula;

(4) necessita de ter uma discussão focalizada;

(5) fornece dados, por meio dos tópicos discutidos, que levem o pesquisador a compreender o tópico de interesse.

Por meio da realização desse grupo focal, esperou-se que os colaboradores revelassem como aconteceu o processo de compreensão dos textos lidos durante as atividades de leitura realizadas durante os seis encontros. Para isso, foram elaboradas três questões que os fizessem refletir sobre cada um dos textos apresentados nas aulas, mais cinco questões incitando discussão acerca da receptividade das aulas e da contribuição do trabalho realizado para a 
ampliação das inferências realizadas nas atividades de leitura e compreensão textual. (vide item 3.5)

Com o objetivo de focalizar a discussão e de não a tornar muito extensa, decidiu-se que o grupo focal seria realizado com seis alunos da turma que colaboraram com esta pesquisa e que optassem por participar dessa atividade de maneira voluntária. Esses seis alunos foram divididos em dois pequenos grupos de três colaboradores, com os quais foram realizadas cada uma das duas sessões de grupo focal. A primeira sessão durou 41 minutos e 20 segundos e teve como foco os textos que tematizaram as leituras coletivas; a segunda sessão durou 26 minutos e 38 segundos e teve como foco as atividades realizadas de maneira individual e, depois, levadas à discussão coletiva com a turma.

\subsection{Relato da geração dos dados: da pesquisa-ação participante crítica ao grupo focal}

Nesta seção, serão descritos todos os encontros com a turma do primeiro módulo do curso técnico subsequente em secretariado escolar do IFB, que constituíram o corpus total da presente pesquisa. Os relatos serão breves, pois as especificações das aulas referentes a esta investigação já foram tratadas nos dois primeiros capítulos e serão retomadas nos capítulos 04 e 05 .

O corpus completo desta pesquisa possui um total de 7 horas, 5 minutos e 40 segundos de aulas gravadas, correspondendo a 06 encontros, além do grupo focal. Das horas gravadas, apenas 1 hora, 40 minutos e 15 segundos não foi transcrita, por se referir ao momento no qual os alunos estavam realizando as atividades escritas.

As gravações das aulas tiveram início no dia 27 de março de 2015 e a última aula gravada foi realizada no dia 22 de maio de 2015. O grupo focal foi realizado no dia 29 de maio de 2015. Todo o percurso do trabalho de campo foi organizado conforme explicitado na Tabela 02.

Tabela 02 - Síntese do percurso metodológico.

\begin{tabular}{|c|l|}
\hline Data & \multicolumn{1}{c|}{ Ações Realizadas } \\
\hline $\mathbf{1 3 / 0 3 / 2 0 1 5}$ & - Apresentação da pesquisadora para turma. \\
& - Apresentação da proposta de pesquisa. \\
& - Solicitação de permissão para geração dos dados. \\
\hline
\end{tabular}




\begin{tabular}{|c|c|}
\hline & $\begin{array}{l}\text { - Explicação acerca do respaldo ético da pesquisa e entrega dos termos de } \\
\text { autorização de coleta de dados e cessão de imagem para preenchimento e } \\
\text { assinatura. }\end{array}$ \\
\hline $27 / 03 / 2015$ & $\begin{array}{l}\mathbf{1}^{\text {a }} \text { aula: apresentação e discussão acerca do gênero textual charge, } \\
\text { selecionado pela professora regente e pela professora-pesquisadora. }\end{array}$ \\
\hline $10 / 04 / 2015$ & $\begin{array}{l}2^{\mathbf{a}} \text { aula: aplicação de atividade escrita de compreensão textual de tirinhas e } \\
\text { charges. }\end{array}$ \\
\hline $17 / 04 / 2015$ & $\begin{array}{l}\mathbf{3}^{\mathbf{a}} \text { aula: discussão coletiva das tirinhas e charges da atividade individual da } \\
\text { aula anterior e inserção de mais algumas charges para análise coletiva. }\end{array}$ \\
\hline 24/04/2015 & $\begin{array}{l}4^{\text {a }} \text { aula: discussão coletiva acerca dos gêneros textuais: anúncio publicitário, } \\
\text { boletim informativo e manchete de jornal/revista. Construção individual de } \\
\text { texto a partir da reportagem com infográfico entregue a cada um dos alunos. }\end{array}$ \\
\hline $08 / 05 / 2015$ & $\begin{array}{l}\mathbf{5}^{\mathbf{a}} \text { aula: entrega das atividades escritas realizadas na aula anterior e leitura } \\
\text { coletiva mediada do texto e do infográfico com os alunos. }\end{array}$ \\
\hline $22 / 05 / 2015$ & $\begin{array}{l}\mathbf{6}^{\mathbf{a}} \text { aula: discussão coletiva acerca dos gêneros textuais: anúncio publicitário, } \\
\text { boletim informativo e manchete de jornal/revista. Início da atividade de } \\
\text { construção de cartazes de divulgação do evento do dia do meio ambiente, a } \\
\text { pedido da professora regente da turma. }\end{array}$ \\
\hline $29 / 05 / 2015$ & Rea \\
\hline
\end{tabular}

Fonte: Autoria própria.

No dia 13 de março de 2015, com a presença da professora regente da turma, a pesquisadora teve o primeiro contato com os alunos do primeiro módulo do curso técnico em secretariado escolar do IFB para se apresentar e pedir permissão para a realização de aulas. Explicou, de modo sucinto, o objetivo da pesquisa de doutorado e esclareceu dúvidas dos alunos a respeito do preenchimento do termo de consentimento livre e esclarecido e do termo de cessão de direitos de uso da imagem, aprovados pelo Comitê de Ética da Universidade de Brasília (Anexo I). Uma aluna questionou a necessidade de inserir o número do registro geral - RG - no termo de cessão de imagem, e a pesquisadora, ratificada pela vice-representante da turma, explicou que essa era uma forma de identificação e de conferir mais autenticidade à assinatura do documento.

Os alunos levaram os termos para casa, e a vice-representante se comprometeu a entregá-los também àqueles que estavam ausentes e a receber os termos assinados de todos os 
demais alunos. Esse primeiro momento não foi filmado, pois a professora-pesquisadora considerou importante essa primeira conversa para conhecer os colaboradores de pesquisa e para sanar dúvidas a fim de que eles tivessem consciência de que se tratava de pesquisa aprovada pelo Comitê de Ética da Universidade de Brasília e para que não se sentissem expostos quando a filmadora fosse colocada ao fundo da sala para gravação dos seis encontros subsequentes, além do grupo focal.

A primeira aula foi realizada no dia 27 de março de 2015, quando a pesquisadora apresentou os primeiros gêneros textuais presentes na apostila de autoria da professora regente da turma, com contribuições da pesquisadora (Apêndice I). Esse material continha diversos textos tratando da crise hídrica e das mudanças climáticas. Ficou combinado, em razão dos objetivos desta pesquisa e da solicitação prévia da professora-pesquisadora, que seria interessante se os textos 04, 05 e 06 da apostila fossem trabalhados na primeira aula da geração dos dados, pois se tratavam de charges - gênero textual multimodal repleto de pistas verbais e não verbais para discussão profícua em sala de aula no que tange à construção das inferências. A professora regente aceitou prontamente essa proposta. Quando a professorapesquisadora entrou em sala, a professora regente já havia trabalhado um vídeo sobre as mudanças climáticas, que correspondia à aula 05 dessa apostila.

Durante essa aula, a professora-pesquisadora fez introdução ao tema apresentando o slide número 01, que dava título ao conjunto de slides que foram apresentados à turma (Apêndice II). Após esse momento de introdução, os alunos foram convidados a fazer a leitura das três charges da apostila e a realizar quatro das cinco questões propostas, sendo que a questão número quatro seria conduzida posteriormente pela professora regente, pois dependia da leitura de um texto que ainda não havia sido trabalhado em sala. Após 27 minutos e 48 segundos, a pesquisadora retomou a discussão coletiva e fez a correção das quatro questões, incluindo uma de cunho gramatical elaborada pela professora regente. Depois do período de correção e discussão acerca das três charges, a pesquisadora apresentou os dois primeiros slides com mais duas charges, cujo tema era a crise hídrica.

Após a primeira aula e com a reflexão sobre a ação da pesquisadora, durante a sessão de orientação da tese, a professora-pesquisadora e a orientadora resolveram modificar a metodologia empregada nas aulas. A decisão implicou a aplicação de atividades individualizadas nas quais os alunos pudessem fazer suas próprias reflexões acerca dos significados dos gêneros textuais "tirinha" e "charge", para que, posteriormente, esses textos 
fossem levados à discussão coletiva. Essa decisão se deveu à necessidade de investigar como cada um dos alunos realizava suas inferências.

E assim foram delineados os encontros dos dias 10 e 17 de abril de 2015 . O dia 10 foi reservado para aplicação da atividade escrita 01 (Apêndice III), contendo 04 charges a serem analisadas por meio da construção de parágrafos nos quais os estudantes escreveriam o que entenderam acerca dos textos apresentados. O propósito da aplicação dessa atividade era investigar de que modo as inferências eram realizadas por cada estudante.

$\mathrm{Na}$ aula do dia 17 de abril de 2015, as atividades foram entregues corrigidas, contendo a devida pontuação combinada com a professora regente da turma. Em seguida, foi realizada a discussão coletiva com o intuito de compartilhar as inferências realizadas pelos alunos e de ampliar a compreensão dos sentidos dos textos lidos, por meio do debate e da troca de experiências.

Além dos quatro textos da atividade de compreensão textual, foram inseridos mais dois textos: uma charge já trabalhada na aula do dia 27 de março de 2015, mas pouco aprofundada; e uma tirinha, cuja compreensão era mais complexa e dependia de análise mais detalhada e do auxílio da professora-pesquisadora por meio do fornecimento de pistas de contextualização (Apêndice II). A intenção da professora-pesquisadora, ao inserir esses dois textos na discussão, foi a de ampliar o debate sobre o tema, ao oferecer mais oportunidades de discussão coletiva para expandir os conhecimentos dos alunos.

Mais adiante, novamente seguindo a metodologia da pesquisa-ação, a professorapesquisadora e a orientadora avaliaram os resultados da nova proposta de investigar atividades escritas e orais, e concluíram que se tratava de metodologia eficaz, pois os dados gerados forneciam diversas possibilidades de estudo para a pesquisadora. Por isso, as aulas dos dias 24 de abril e 08 de maio de 2015 foram delineadas do seguinte modo: primeiro, aplicou-se a segunda atividade escrita (Apêndice V) e, posteriormente, fez-se a discussão coletiva acerca do mesmo texto.

Mesmo a metodologia estando adequada à proposta da pesquisa, foi percebida a necessidade de ampliação dos gêneros textuais para discussão do tema. Por isso, foram inseridos os gêneros textuais anúncio publicitário, manchete de jornal/revista, boletim informativo de rádio e reportagem nos slides trabalhados (Apêndice IV) antes da aplicação da atividade 02. Todos os textos selecionados versavam sobre a "crise hídrica" - tema fornecido pela professora regente e que fazia parte do projeto desenvolvido por ela. Houve, assim, mais uma vez, a reflexão sobre a ação e a reestruturação do planejamento. 
A aula do dia 24 de abril de 2015 foi destinada à aplicação da atividade escrita (Apêndice V) e teve como proposta construir um texto sobre o tema "crise hídrica", com base nas discussões já realizadas em sala e na leitura da reportagem proveniente da revista Super Interessante (Anexo II), que faz parte de uma edição especial sobre a crise da água, tema que ganhou grande repercussão na mídia a partir de outubro de 2014. A reportagem foi publicada no site da revista (http://super.abril.com.br/crise-agua/ofundodopoco.shtml). Nela consta infográfico com informações sobre o nível de água no sistema Cantareira, em São Paulo, no qual era possível acompanhar, em tempo real, a situação da crise do reservatório de água mais importante do estado de São Paulo.

A pesquisadora, antes de entregar a reportagem com a folha de produção aos alunos, apresentou anúncio publicitário de conscientização acerca da crise hídrica e os convidou a escutarem o boletim informativo da rádio Nova Brasil FM sobre economia de água (texto 01, p. 28). Depois disso, também apresentou a manchete do jornal Folha de São Paulo sobre o controle do banho em academias de ginástica de São Paulo. Todos os textos foram apresentados e seguidos de discussão coletiva. Depois desse momento, a pesquisadora distribuiu a reportagem da revista Super Interessante acompanhada de folha de produção textual para que os alunos pudessem realizar a atividade de produção de texto.

Antes de os alunos iniciarem seus trabalhos individuais, a pesquisadora julgou necessário apresentar o material que era bastante multimodal, por possuir imagens, texto e infográfico. Assim, explorou com os alunos a manchete da reportagem e o seu título sem fazer afirmações fechadas, mas levando os alunos a refletirem sobre a expressão do título $O$ fundo do poço. Em seguida, aconselhou os alunos a voltarem seus olhares ao texto escrito, mas não somente a ele, explicitando a necessidade de prestarem atenção às informações fornecidas pelas imagens e pelo infográfico. A pesquisadora inferiu que praticamente todos os alunos não sabiam do que se tratava um infográfico. Por essa razão, julgou necessário apresentar esse gênero textual e sugerir como fazer sua leitura.

Posteriormente, os alunos silenciaram para ler e produzir o texto com o tema solicitado. Essa atividade durou até o final da aula e estendeu-se até o intervalo, haja vista que alguns alunos não conseguiram entregar seus textos antes desse prazo..

$\mathrm{Na}$ aula do dia 08 de maio de 2015, foi realizada a entrega dos textos produzidos pelos alunos no encontro anterior, devidamente corrigidos e com a nota que havia sido acordada com a professora regente da turma. Nesse dia, ocorreram problemas técnicos que tornaram inviável a apresentação dos slides (Apêndice IV) para análise de mais dois anúncios 
publicitários: um boletim informativo de rádio e uma manchete de jornal. A pesquisadora utilizou, então, esse encontro para realizar a leitura coletiva da reportagem $O$ fundo do poço, da revista Super Interessante, texto analisado pelos alunos na aula anterior.

A priori, a aula do dia 08 de maio de 2015 seria o último dia da gravação de aulas para geração de dados. O grupo focal seria realizado na semana subsequente, finalizando essa etapa da pesquisa. Todavia, em razão do problema técnico com o data show, a pesquisadora entrou em contato com a professora regente, que cedeu gentilmente a aula do dia 22 de maio de 2015 para que fosse realizada a leitura coletiva dos textos citados. Como essa atividade de leitura não ocuparia todo o tempo da aula, a professora-pesquisadora comprometeu-se em iniciar a atividade, em grupos, de produção dos cartazes para divulgação do evento do dia do meio ambiente, que fazia parte do projeto interdisciplinar desenvolvido pela professora regente em conjunto com o professor do componente curricular "Sociedade e Meio Ambiente" e que tematizou todas as aulas desenvolvidas para a geração dos dados desta pesquisa.

A aula do dia 22 de maio de 2015 foi iniciada com a presença da professora regente, que decidiu participar do encontro para dar as instruções referentes à construção dos cartazes de divulgação do dia do meio ambiente. Após dar as instruções sobre como a aula desse dia seria desenvolvida, a professora regente saiu da sala para que a pesquisadora pudesse apresentar os demais slides que não haviam sido lidos na aula anterior. Os slides foram apresentados e discutidos coletivamente com os colaboradores da pesquisa e, antes da metade da aula, a professora regente assumiu a aula para dar continuidade à atividade prática de construção de cartazes.

No dia 29 de maio de 2015 foi realizado o grupo focal. Para realizar essa etapa da geração de dados, a pesquisadora teve de entrar em contato com o professor da disciplina Gestão de Pessoas e Relações Interpessoais e pedir autorização para interromper sua aula com a turma do primeiro módulo do curso técnico em secretariado escolar do IFB, com a finalidade de solicitar colaboradores voluntários para participar do grupo focal.

Três alunos se dispuseram a participar da primeira sessão do grupo focal. Naquele momento, todos os textos discutidos coletivamente foram reapresentados aos colaboradores e, para investigar de que modo havia ocorrido o processo de compreensão, foram feitas três perguntas $^{52}$, que os colaboradores foram respondendo a cada texto apresentado. Nem todos os

\footnotetext{
${ }^{52}$ As três perguntas realizadas foram estas: (1) O que você pensou quando viu a gravura?; (2) Você relacionou a gravura com o quê?; (3) Como você compreendeu o texto?
} 
textos foram discutidos nessa primeira sessão devido à falta de tempo para debater todos os textos lidos pela turma. Assim, a pesquisadora pedia que cada aluno escolhesse um entre dois textos para que houvesse tempo hábil para a realização da segunda sessão, a qual contou com a participação de outros três colaboradores. Nessa segunda sessão, a pesquisadora apresentou apenas os textos que fizeram parte das atividades escritas para que os participantes pudessem fornecer pistas a respeito de como havia ocorrido o processo de compreensão dos textos. As três perguntas que acompanharam os textos feitos na primeira sessão do grupo focal foram as mesmas para esse segundo momento.

Ao final de ambas as sessões do grupo focal, foram feitas cinco perguntas ${ }^{53}$, que tiveram o objetivo de investigar como as atividades de leitura e compreensão textual realizadas nas seis aulas colaboraram para a aprendizagem dos colaboradores e como elas poderiam ser aprimoradas para funcionarem de modo mais produtivo como facilitadoras no processo de leitura e compreensão dos textos.

\subsection{Reflexões sobre o percurso metodológico}

Todas as seis aulas realizadas e o grupo focal foram atividades discutidas, planejadas e reelaboradas durante o processo de geração de dados. Foram vários os textos selecionados pela pesquisadora e apresentados nas sessões de orientação com o objetivo de eleger aqueles que garantissem geração de dados eficiente e coerente com os objetivos desta investigação.

Todo o processo de geração dos dados pode ser inserido no esquema de pesquisaação proposto primeiramente por Lewin (1946) e repensado por Trip (2005) e por Kemmis \& McTaggart (2005). Assim, o percurso desta pesquisa pode ser representado por meio da Figura 21.

\footnotetext{
${ }^{53}$ As cinco perguntas feitas para finalizar o grupo focal foram as seguintes: (1) O que vocês aprenderam com os 06 encontros?; (2) Como vocês aprenderam o assunto por meio dos textos?; (3) Nas atividades realizadas, quais aspectos que mais contribuíram para que vocês compreendessem os textos?; (4) Quais atividades mais colaboraram para que vocês compreendessem o assunto?; (5) O que vocês acham que os professores podem fazer para aprimorar a compreensão textual da turma?. As respostas serão analisadas na seção 5.3 (p. 183).
} 
Figura 21 - Percurso Metodológico da pesquisa-ação participativa crítica.

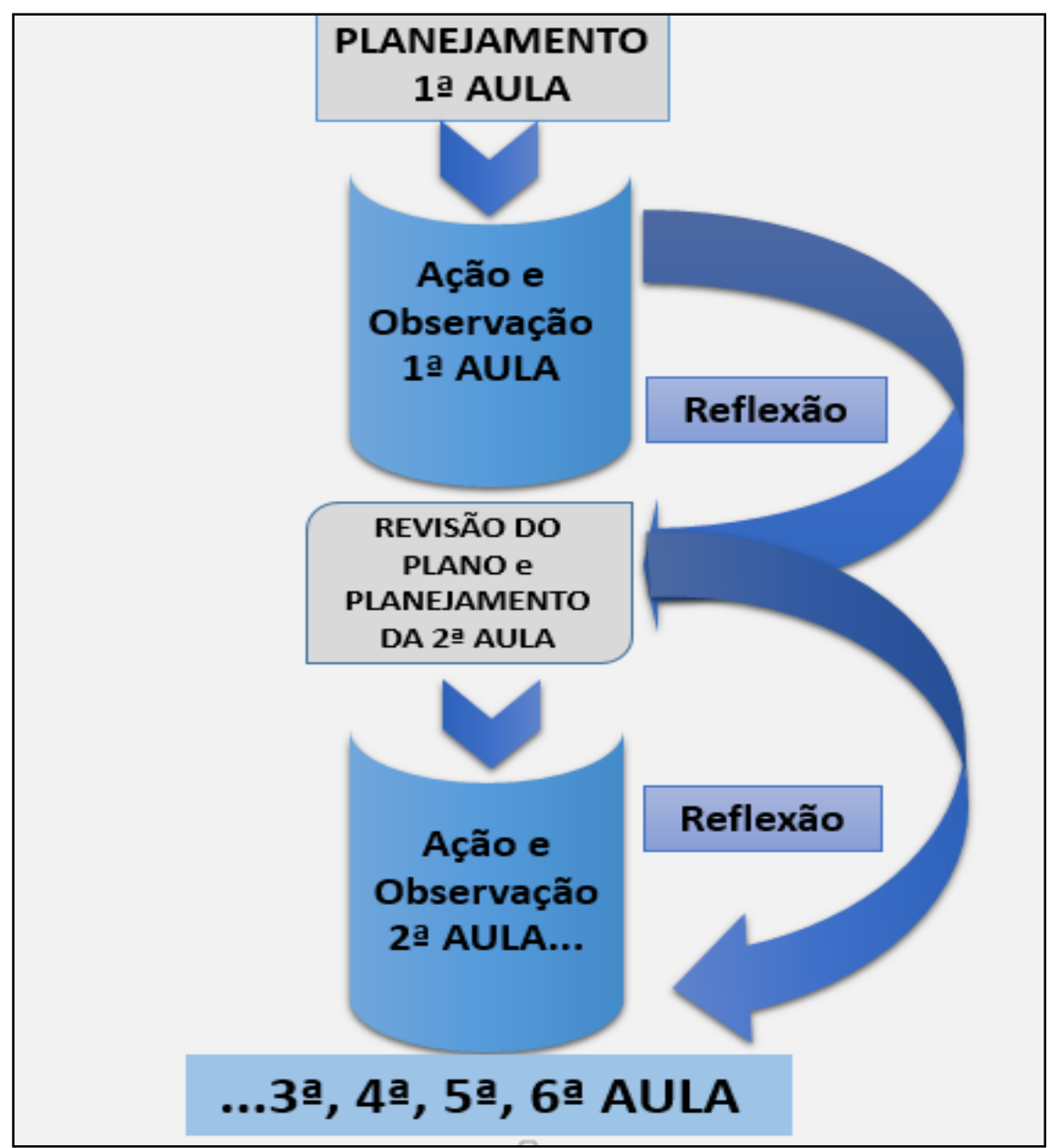

Fonte: Autoria própria

Como se pode notar, esta pesquisa se alinha com a metodologia da pesquisa-ação, mas possui particularidades, descritas ao longo deste capítulo, que não a tornam uma pesquisaação completamente fiel à forma como foi concebida por Kurt Lewin, em 1946. A Figura 21 revela a proposta de pesquisa-ação participativa crítica, que, após toda revisão teórica sobre como a pesquisa-ação vem se desenvolvendo ao longo dos anos, foi concebida como proposta metodológica deste trabalho. 


\section{CAPÍTULO 4}

\section{O TEXTO COMO PROTAGONISTA DA AULA}

O texto é o resultado de uma ação linguística cujas fronteiras são em geral definidas por seus vínculos com o mundo no qual ele surge e funciona. (...) O texto pode ser lido como um

tecido estruturado, uma unidade significativa, uma entidade de comunicação e um artefato sócio-histórico. De certo modo, pode-se afirmar que o texto é uma (re)construção do mundo e não uma simples refração ou reflexo.

(Luiz Antônio Marcuschi, 2008, p. 71-72)

\subsection{Primeiras palavras}

Neste capítulo, o texto será tratado como elemento central das atividades de leitura e, como protagonista que é, será compreendido não somente como junção de unidades morfológicas e sintáticas, mas como unidade de sentido que integra as práticas sociointerativas nas quais os sujeitos estão inseridos, constituindo-se como artefato sóciohistórico. BEAUGRANDE \& DRESSLER, 1981; MARCUSCHI, 2008; VAN DIJK, 2009).

Assim, esta seção do trabalho irá se dedicar, primeiramente, a situar o texto nos estudos linguísticos. Serão apresentados os principais conceitos e enfoques da Linguística Textual (LT) ao longo das quatro décadas dessa disciplina e a posição teórica de texto assumida neste estudo. A segunda subseção irá apresentar as perspectivas social e discursiva do texto por meio das teorias sobre os gêneros textuais que mais se aproximam da proposta deste trabalho, a fim de relacioná-las com as práticas realizadas em sala de aula, exemplificando-as com excertos oriundos do corpus da pesquisa.

Mais adiante, serão apresentados, brevemente, os principais conceitos referentes à Semiótica Social (VAN LEEUWEN, 2005) e à Gramática do Design Visual (KRESS \& VAN LEEUWEN (2006[1996], p.03) a fim de abordar a multimodalidade como aspecto não somente comum aos textos que foram usados nas atividades de compreensão textual que compõem esta pesquisa, como também atributo de quaisquer textos, sejam eles orais ou escritos, verbais e/ou não verbais. Além disso, serão discutidas as principais teorias relacionadas aos gêneros textuais. (BAKHTIN, [1979] 1997; MARCUSCHI, 2010; MILLER, 1984; BONINI, 2002 e 2007)

Finalmente, no item 4.4, serão estudadas as inferências realizadas pelos alunos na primeira atividade escrita com base nos conceitos já apresentados e defendidos nos estudos da 
argumentatividade (KOCH, 2009c e VOGT, 1980) presente nos textos (Semântica Argumentativa) e na concepção de compreensão textual como processo interativo.

\title{
4.1 Linguística Textual: conceitos e enfoques
}

A Linguística textual, até ser concebida como disciplina que investiga as relações linguísticas e discursivas presentes nos textos, passou por vários períodos que correspondem, primeiramente, a uma visão do texto somente como estrutura linguística e, depois, a uma visão mais ampla que abarca as visões micro e macroestrutural do texto, deixando de ser concebido somente do ponto de vista linguístico para ganhar status sociointeracional. Marcuschi, em conferência pronunciada no IV Congresso Brasileiro de Língua Portuguesa, em junho de 1983, afirmou que

\begin{abstract}
a Linguística de texto (LT), tal como é conhecida hoje, surgiu na década de 60. Desenvolveu-se rapidamente e em várias direções (...). Dispõe (...) de um dogma de fé: o texto é uma unidade linguística hierarquicamente superior à frase. E uma certeza: a gramática de frase não dá conta do texto. (MARCUSCHI, 2012, p.16)
\end{abstract}

Conforme Koch (2009b, p. 03-33), o texto passou a ser objeto de investigação da Linguística a partir de pesquisas que perpassaram as décadas de 60, 70, 80 e 90. Conforme as tendências teóricas da LT, os estudos podem ser compreendidos nas seguintes etapas: (1) análises transfrásticas e criação das gramáticas textuais; (2) virada pragmática; e (3) virada cognitivista (incluindo a perspectiva sociocognitivista). Todos esses três momentos serão aqui caracterizados a fim de apresentar a concepção de texto adotada neste estudo, justificando como ela se enquadra no modo pelo qual a professora-pesquisadora conduziu as atividades realizadas em sala de aula.

As análises transfrásticas vêm da tradição estruturalista quando fenômenos relacionados à linguagem não conseguiam mais ser explicados no nível da sintaxe e da semântica, pois envolviam estruturas textuais complexas. Conforme Bentes (2012, p.263), a análise transfrástica parte da frase para o texto, ou seja, analisa primeiramente as estruturas das frases para, depois disso, partir para a análise do período. Tem-se em Isenberg $(1970)^{54}$ a definição de texto como sequência coerente de enunciados e, naquele momento, o estudo do texto estava voltado para o estudo das possíveis relações estabelecidas entre os diversos enunciados, sendo a correferenciação considerada como um dos principais fatores para coesão

\footnotetext{
${ }^{54}$ Isenberg (1970) é citato por Fávero e Koch (2008, p.13).
} 
textual. Para Harweg $(1968)^{55}$, eram os pronomes que faziam com que um texto pudesse ser entendido como texto. Esse autor entende texto como uma sucessão de unidades linguísticas constituída mediante uma concatenação pronominal ininterrupta (FÁVERO \& KOCH, 2008, p.14). Esse primeiro momento, embora ainda tratasse o texto dentro das estruturas linguísticas, constituiu o início da visão do texto como área importante da Linguística, pois os limites da frase foram superados, havendo necessidade da criação de uma gramática textual que compreendesse as relações entre os elementos textuais, não mais explicáveis pelos estudos do enunciado. (Ibid)

Consoante Koch (2009b, p.05), as gramáticas de texto constituem, juntamente com as análises transfrásticas, a primeira fase da Linguística Textual, que aconteceu entre meados da década de 60 e a década de 70 . Naquele momento, entendia-se que o texto seria a unidade mais alta de análise linguística, que estava acima da sentença. Devido a essa concepção, muitos linguistas, especialmente os gerativistas, preocupavam-se em construir uma gramática textual que descrevesse categorias e regras em combinações possíveis de texto (T) em uma determinada língua (L). (Ibid)

Nessa primeira fase, iniciou-se também a preocupação em investigar as macroestruturas profundas dos textos. Destacam-se, entre os autores, van Dijk (1972), Dressler (1970, 1972), Brinker (1973), Rieser (1973, 1978), Viehweger (1976, 1977) e Charolles $(1979)^{56}$. As pesquisas realizadas por esses autores revelaram a importância da análise textual na perspectiva semântica. Assim, além das questões de coesão textual mais relacionadas aos aspectos gramaticais do texto, aspectos que dizem respeito à coerência textual, mesmo que associados ainda ao nível da coerência sintático-semântica, passaram a compor a agenda dos estudos linguísticos interessados no texto.

Todos esses estudos contribuíram para a virada pragmática, momento em que o texto passou a ser estudado considerando as relações sociais nas quais sua produção ocorria. Esse momento é caracterizado por Koch (2009b, pp.13-14) como uma nova fase da pesquisa linguística.

[A] pesquisa em Linguística Textual ganha uma nova dimensão: já não se trata de pesquisar a língua como sistema autônomo, mas sim o seu funcionamento nos processos comunicativos de uma sociedade concreta. (...) Isto é, os textos deixam de ser vistos como produtos acabados, que devem ser analisados sintática e semanticamente, passando a ser considerados elementos constitutivos de uma atividade complexa, como instrumentos de realização de intensões comunicativas e sociais do falante. (KOCH, 2009b, p.14)

\footnotetext{
${ }^{55}$ Harweg (1968) é citado por Fávero e Koch (2008, p.14).

${ }^{56}$ Todos esses autores foram citados por Koch (2009b, p.09).
} 
Foi a partir da metade da década de 70 que os estudos linguísticos passaram a considerar a língua como modo de comunicação social e como atividade verbal humana interconectada com outras atividades, inclusive as não linguísticas. Essas novas concepções foram construídas sob influência da Psicologia da Linguagem e da Filosofia da Linguagem, com a Teoria dos Atos de Fala ${ }^{57}$, desenvolvida por John Austin e continuada por John R. Searle. (Ibid)

Também a Teoria da Atividade Verbal contribuiu para essa nova acepção de linguagem. Desenvolvida em países da antiga $\mathrm{URSS}^{58}$, com base nas ideias dos psicólogos e psicolinguistas soviéticos, ela tem Luria e Leontev, seguidores das ideias de Vygotsky (vide capítulo 02), como principais representantes. Essa teoria concebe a linguagem como atividade social, com vistas à realização de determinados objetivos e, por isso, passa a dar atenção às estratégias que o interlocutor utiliza para captar a intenção do ato de fala. (KOCH, 2012, p.23-24)

A crítica às referidas teorias reside na questão de elas estudarem os atos de fala em pequenos enunciados, desconsiderando os casos nos quais o texto é composto por conjuntos de enunciados que realizam diversos potenciais ilocutórios. Por exemplo, um e-mail pode realizar pedidos, justificativas e agradecimentos ao mesmo tempo (KOCH, 2009b, p.16). Com isso, van Dijk desenvolve, na década de 80, o conceito de macroato de fala, que diz respeito a como os interlocutores interpretam as sequências de atos de fala por meio de associações entre os atos de fala subsequentes. Um exemplo dado pelo autor é a sequência de atos de fala utilizada quando alguém diz que está com fome para, depois, pedir a comida. Esses atos se combinam de modo que o interlocutor tenha capacidade de prever os atos de fala e determinar as informações pragmáticas relevantes para realizar inferências dos atos de fala subsequentes. (VAN DIJK, 2010, p.93-94)

Os trabalhos de van Dijk e Beaugrande \& Dressler, na década de 80, delinearam nova orientação aos estudos do texto, uma vez que o texto, sendo concebido como ação, é constituído por processos cognitivos (que levariam à ação). Haveria, então, sequências de atividades cognitivas interligadas que deveriam ser estudadas pela Linguística Textual

\footnotetext{
57 A Teoria dos Atos de Fala foi postulada pelo filósofo inglês John Austin (AUSTIN, 1962 e 1990) e, posteriormente, desenvolvida por Searle. Essa teoria surgiu dentro da Filosofia da Linguagem, mas foi posteriormente incorporada aos estudos da Linguística e da Pragmática. Conforme essa teoria, a linguagem é uma forma de ação. Quando falamos, não apenas declaramos algo, mas ordenamos, julgamos, reclamamos etc. (KOCH, 2012, p.17-18). Searle (1969), em seu livro Speech Acts, retoma questões importantes concernentes às tendências contemporâneas da Filosofia da Linguagem, utilizando o conceito de finalidade ilocutória para classificar os usos linguísticos. Com isso, ele amplia a teoria dos atos de fala de Austin. (WILSON, 2009, p.93)

${ }^{58}$ União das Repúblicas Socialistas Soviéticas formada pela Rússia e demais países do leste europeu.
} 
(KOCH, 2009b, p.21). As estratégias cognitivas utilizadas pelos interlocutores referem-se às atividades mentais usadas por estes para compreenderem os textos. A inferência, objeto de estudo desta pesquisa, é uma das estratégias cognitivas que geram informação nova a partir das anteriores. Na visão de Koch (2009b, p.27),

\begin{abstract}
[a]s inferências constituem estratégias cognitivas por meio das quais o ouvinte ou leitor, partindo da informação veiculada pelo texto e levando em conta o contexto (em sentido amplo), constrói novas representações mentais e/ou estabelece uma ponte entre seguimentos textuais, ou entre a informação explícita e informação não explícita no texto.
\end{abstract}

Beaugrande \& Dressler ([1981] 1988, p.06) entendem a inferência como a adição de conhecimentos próprios ao texto. Para esses autores, o texto não faz sentido por si só, mas sim pela interação entre o conhecimento por ele apresentado e o conhecimento de mundo adquirido pelas pessoas. Há, nessa concepção de Beaugrande \& Dressler, o início da concepção de texto como atividade dinâmica, que quando realizada, irá gerar coerência, pois os textos só se tornam coerentes para o leitor/ouvinte por meio da inferenciação. (KOCH, 2009b, p.27)

O trabalho de Beaugrande \& Dressler (1981) representa o ponto de partida para a compreensão do texto pelos fatores de textualidade. Esses autores $(1981, \text { p.03) })^{59}$ entendem ser o texto uma ocorrência comunicativa que deve satisfazer sete critérios de textualidade ${ }^{60}$ para que seja considerado como tal: (1) coesão; (2) coerência; (3) intencionalidade; (4) aceitabilidade; (5) informatividade; (6) situacionalidade; e (7) intertextualidade.

Os princípios de textualidade, propostos por Beaugrande \& Dressler (1981), juntamente com a visão de van Dijk (2009), que ampliou a noção de texto ao discutir os fatores contextuais e pragmáticos presentes na constituição do texto escrito ou falado, forneceram suporte para a construção de teorias voltadas para o estudo do texto na perspectiva sociocognitivo-interacionista, quando questões interiores e exteriores relacionadas à compreensão do texto passaram a não ser mais vistas separadamente. Essa mudança de paradigma indica que os estudos da Linguística Textual passaram a considerar que os processos mentais envolvidos na produção e na compreensão do texto precisavam ser estudados juntamente com os fatores socioculturais.

Para Marcuschi (2008, p.87), o texto é constituído de dois tipos de relações: as cotextuais, que se referem aos aspectos sintáticos e morfológicos, assim como aos elementos coreferenciais e as relações semânticas de causa e efeito; e as situacionais, que dizem respeito

\footnotetext{
59 Tradução própria.

${ }^{60}$ Koch (2009b, p.29) prefere nomear esses critérios como princípios de construção textual de sentido.
} 
ao contexto situacional ou inserção cultural, social, histórica e cognitiva, envolvendo conhecimentos individuais e coletivos.

Este trabalho considera os aspectos co-textuais como elementos fundamentais na constituição do texto, todavia, seu foco de análise se volta mais para os aspectos sóciohistórico-culturais dos textos, que produzem efeitos de sentidos nos sujeitos sociais que os leem. Assim como Marcuschi (2008, p.87), este trabalho defende uma visão sociointerativa de texto, que elege a situacionalidade (ou inserção sociocultural) como um dos fatores de textualidade mais importantes para a compreensão efetiva do texto, uma vez que, como destaca esse autor (ibid) todo sentido é sentido situado.

Figura 22 - Critérios gerais de textualidade.

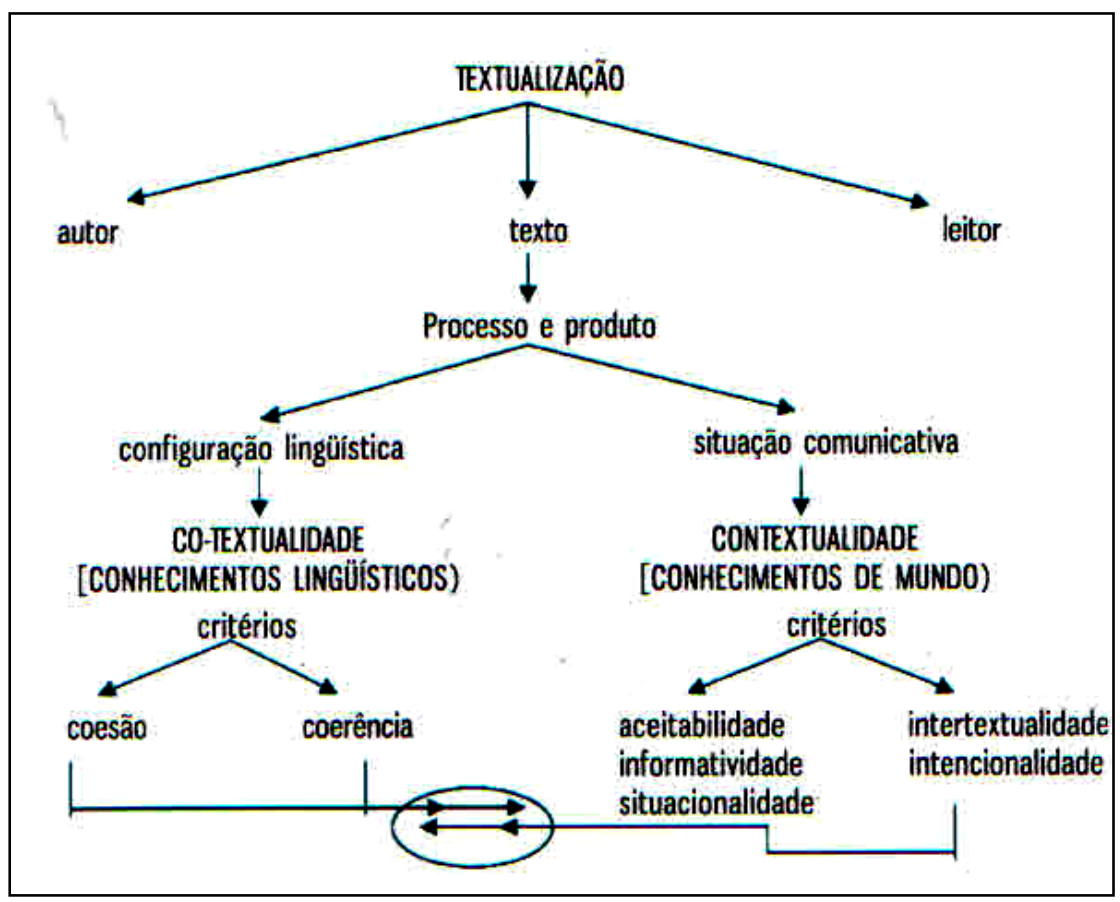

Fonte: Marcuschi (2008, p.96)

Marcuschi (2008, p.87-96) resume, discute e fornece visão inovadora a respeito da teoria desenvolvida por Beaugrande \& Dressler (1981) sobre os critérios de textualidade e revela, por meio do esquema (Figura 22), os três pilares da textualidade: autor e leitor (interlocutores) e texto. O terceiro pilar é, para esse Marcuschi (ibid), considerado como um evento, em virtude do caráter social de sua produção. O texto também constitui processo e produto e, neste trabalho, seu caráter processual é mais destacado, pois o objeto de investigação é o processo de compreensão do texto por meio da produção de inferências. 
Como condição para a produção de sentido, Marcuschi (ibid) ressalta que o texto deve apresentar configuração linguística e situação comunicativa. A coesão e a coerência pertencem à configuração linguística do texto (co-textualidade), responsável pelos conhecimentos linguísticos envolvidos no sistema que fornecem acesso cognitivo pelo aspecto estritamente linguístico (intratexto).

No que diz respeito à situação comunicativa (contextualidade) em que o texto se insere, o acesso cognitivo é fornecido pelo aspecto contextual (situacional, social, histórico, cognitivo, enciclopédico) e exige conhecimentos de mundo e sociointerativos. Pertencem à situação comunicativa os cinco critérios de textualidade (aceitabilidade, informatividade, situacionalidade, intertextualidade e intencionalidade), que se inter-relacionam com os outros dois critérios (coesão e a coerência). Marcuschi (2008, p.96-97) defende uma noção de contexto rica, dinâmica e maleável, na qual os critérios linguísticos e extralinguísticos não sejam analisados separadamente, mas de maneira complementar, uma vez que os critérios de textualidade, propostos por Beaugrande \& Dressler (1981), não constituem princípios de formação textual e sim critérios de acesso à produção de sentido. (MARCUSCHI, 2008, p.97)

Em estudos posteriores, Beaugrande (1997, p. 13) ampliou a concepção de texto como evento comunicativo no qual convergem ações linguísticas, cognitivas e sociais, e ampliou, na Linguística Textual, o objeto de estudo, ao considerar o texto como processo construído na e pelas práticas sociais, sendo que os sete princípios de textualidade estabelecidos em Beaugrande \& Dressler (1981) passaram a ser vistos não somente como critérios obrigatórios que um texto precisa ter para ser considerado como tal, mas passaram a constituir uma ação linguística, cognitiva e social, na qual eles se inter-relacionam. (KOCH, 2001, p.16)

Desse modo, o objeto da Linguística Textual, diferentemente dos estudos iniciados na década de 70, passa a ser o texto como uma unidade teoricamente nova e não apenas uma frase ampliada (análises transfrásticas). Da mesma forma, o texto não pode ser considerado uma simples sucessão de enunciados interligados e nem como uma unidade linguística. $\mathrm{Na}$ verdade, o texto é uma unidade de sentido e uma atividade sistemática de atualização discursiva da língua na forma de gênero ${ }^{61}$. (MARCUSCHI, 2008, p.97)

Portanto, convém apresentar as definições de texto e de Linguística Textual que mais dialogam com a proposta deste trabalho.

\footnotetext{
${ }^{61}$ Os conceitos de gêneros textuais serão apresentados mais adiante, no item 4.2 deste capítulo.
} 
Um texto está submetido tanto a controles e estabilizadores internos como externos (grifos do autor), de modo que uma LT razoável não deve considerar a estrutura linguística como fator único para a produção, estabilidade e funcionamento do texto. Nem se pode tratar o texto simplesmente como uma unidade maior que a sentença, pois ele é uma entidade de outra ordem na medida em que é uma ocorrência na comunicação (grifo do autor) (...). O texto forma uma rede em várias dimensões e se dá como um complexo processo de mapeamento cognitivo de fatores a serem considerados na produção e na recepção. (MARCUSCHI, 2012, pp.29-30)

Logo, a concepção de texto apresentada nas obras de Marcuschi compreende-o como produto social, histórico e cultural, que deve ser estudado considerando não somente os aspectos internos já investigados pelas análises transfrásticas e ampliados pela apresentação dos critérios de textualidade, mas, principalmente, por pesquisas linguísticas que investiguem as relações contextuais presentes na produção e na compreensão dos textos e o modo como elas ocorrem quando as inferências são produzidas nas atividades de leitura.

Nos estudos atuais sobre texto, referenciação e sua relação com as práticas educacionais, as obras de Cavalcante (2012) e Cavalcante et al. (2015) reiteram a visão sociointeracional de texto construída pela Linguística Textual, a partir da década de 90, e a relacionam ao trabalho com o texto em sala de aula.

Cavalcante (2012, p.19) apresenta a concepção atual de texto como processo de interação. Para ela,

hoje, o entendimento sobre o que vem a ser um texto é balizado pela noção de interação. O texto, então, é tomado como um evento no qual os sujeitos são vistos como agentes sociais que levam em consideração o contexto sociocomunicativo, histórico e cultural para a construção dos sentidos e das referências dos textos. (CAVALCANTE, 2012, p.19)

Como a concepção de texto adotada neste trabalho é a de um evento social e sociointerativo, é preciso compreender o contexto em que ele é produzido e divulgado para realizar qualquer trabalho em sala de aula, uma vez que o contexto de produção é essencial para o reconhecimento do estatuto do texto e, consequentemente, da sua coerência (CAVALCANTE et al., 2015, p.20). A análise do contexto de circulação do texto é condição primordial à atribuição de sua coerência, tendo em vista sua compreensão, e envolve trabalho cognitivo colaborativo dos interlocutores, que, conforme Cavalcante et al. (2015, p. 21), passam a ser vistos como coenunciadores, ou seja, aqueles que participam ativamente da coerência por meio da reativação dos conhecimentos armazenados na memória, além da ativação de novos conhecimentos através da interação, quando o texto é utilizado como objeto das interações realizadas em sala de aula. 
Cabe, ainda, apresentar a posição defendida por Cavalcante \& Custódio Filho (2010, p.64) e ratificada neste trabalho a respeito da abrangência da concepção de texto. Para esses autores (ibid), a aludida natureza multifacetada do texto comporta em sua constituição a possibilidade de a comunicação ser estabelecida não apenas pelo uso da linguagem verbal, mas pela utilização de outros recursos semióticos. Esse pensamento leva à conclusão de que o texto deve ser entendido aqui em suas manifestações verbais e não verbais, uma vez que a variedade de gêneros textuais selecionados pela professora-pesquisadora incluiu textos com diversos recursos semióticos em sua produção. A ampliação da noção de texto que ultrapassa os aspectos verbais foi retomada pelos estudos da multimodalidade ${ }^{62}$ ao compreenderem que os textos produzidos pela sociedade pós-moderna possuem, cada vez mais, diversos recursos semióticos que demandam novas posturas para sua leitura e compreensão.

Fica claro, desse modo, que a noção de texto foi sendo ampliada e amadurecida ao longo dos anos ao ponto de ele ser considerado evento sociocognitivo-interacional, que deve privilegiar os sujeitos e seus conhecimentos em processo de interação (KOCH e ELIAS, 2006, p.12). Essas novas formas de compreender e tratar o texto demandam práticas escolares que privilegiem a interação entre os conhecimentos do autor do texto e os conhecimentos dos leitores-alunos, que passam a ter papel ativo no exercício da compreensão textual, entendida aqui como processo colaborativo e, portanto, interacional.

\subsection{Perspectiva social e discursiva do texto: $o$ estudo dos gêneros ${ }^{63}$}

As teorias acerca dos gêneros remontam à antiguidade clássica e romana, bem como à tradição literária, relacionando-se, primeiramente, aos gêneros literários e à estilística. Por sua vez, Bakhtin ([1979] 1997) apresentou nova noção dos gêneros mais relacionada à enunciação presente nas práticas comunicativas. Ao relacionar gênero e discurso, Bakhtin (ibid) iniciou uma nova perspectiva para os estudos interessados nos textos. Mesmo que sua análise se relacionasse, incialmente, com gêneros literários, esse teórico ampliou o conceito de gênero ao relacioná-lo com as práticas sociais.

\footnotetext{
${ }^{62}$ A multimodalidade será tratada, mais detalhadamente, no item 4.3.

${ }^{63}$ Em concordância com Marcuschi (2008, p.154), não há necessidade de se discutir qual das expressões gêneros do discurso, gêneros discursivos ou gêneros textuais (grifos do autor) é a mais pertinente. Para esse autor, todas essas expressões podem ser usadas intercambiavelmente, exceto nos momentos em que se pretender, de modo explícito e claro, identificar algum fenômeno específico. (Ibid)
} 
Qualquer enunciado considerado isoladamente é, claro, individual, mas cada esfera de utilização da língua elabora seus tipos relativamente estáveis de enunciados, sendo isso que denominamos gêneros do discurso. A riqueza e a variedade dos gêneros do discurso são infinitas, pois a variedade virtual da atividade humana é inesgotável, e cada esfera dessa atividade comporta um repertório de gêneros do discurso que vai diferenciando-se e ampliando-se à medida que a própria esfera se desenvolve e fica mais complexa. (BAKHTIN, [1979] 1997, p.280)

A comunicação verbal, na visão de Bakhtin (ibid), seria impossível se não existissem os gêneros do discurso e se eles não fossem dominados pelos sujeitos. Esse autor reconhece a amplitude dos estudos sobre os gêneros devido a sua heterogeneidade e propõe que eles sejam considerados como gêneros primários e gêneros secundários. Os gêneros primários são aqueles que ocorrem nas atividades mais simples e estão relacionados às atividades verbais espontâneas, como a saudação. Por sua vez, os gêneros secundários são aqueles considerados mais complexos, formados pelos gêneros primários e utilizados com finalidades públicas, ou seja, são constituídos por textos valorizados socialmente em razão de sua utilidade pública (ROJO \& BARBOSA, 2015, p.18). Bakhtin ([1979] 1997, p.282) afirma que os gêneros primários passam a compor os secundários e adquirem características particulares. Como exemplo, o autor cita a carta e a saudação, que, ao serem inseridas no gênero secundário romance, compondo as ações dos personagens, adquirem características próprias.

É preciso reconhecer que a classificação dos gêneros do discurso como primários e secundários, realizada por Bakhtin, marcou considerável avanço teórico no estudo do enunciado, uma vez que se iniciou o reconhecimento das funções sociais do texto e sua relevância nas esferas sociais públicas e privadas. O texto ganhou espaço nos estudos linguísticos quando passou a ser visto não apenas nos contextos formais em que eram realizados, mas também no reconhecimento de gêneros textuais produzidos no dia a dia.

Todavia, na sociedade pós-moderna, observa-se fronteira tênue existente entre oralidade e escrita, uma vez que não é mais possível estabelecer diferenças entre os gêneros primários e secundários pela rapidez com que eles são produzidos, consumidos e transformados na atualidade, de forma que os gêneros primários e secundários se fundiram. Desse modo, Marcuschi (2008, pp.154-156) apresenta novo modo de análise dos gêneros textuais, ao reconhecer que eles são formados por tipos textuais ou sequências textuais tipológicas ${ }^{64} \mathrm{e}$ produzidos em determinado domínio discursivo. As sequências ou tipos

\footnotetext{
${ }^{64}$ Adam (1992) inicia as discussões sobre tipos textuais, fazendo a classificação das sequências textuais como narrativas, descritivas, argumentativas, explicativas e dialogais. Já Marcuschi (2008, p.154-155) apresenta cinco tipos textuais ou sequências tipológicas cujas categorias são limitadas: argumentação, narração, exposição, descrição e injunção. Optou-se, neste trabalho, pela utilização da classificação de Marcuschi, em razão da maneira contextualizada como este autor trata cada sequência tipológica.
} 
textuais revelam a natureza linguística e composicional do texto (aspectos lexicais, sintáticos e morfológicos). Assim, entende-se que a charge, a tirinha ou o cartaz publicitário, por exemplo, constituem gêneros textuais diferentes, mas que podem possuir, em suas composições, sequências textuais narrativas, descritivas, expositivas, argumentativas e/ou injuntivas.

Para uma análise mais ampla dos textos, também é necessário considerar o domínio discursivo em que eles são produzidos, ou seja, as instâncias discursivas (discurso jurídico, discurso publicitário, discurso político). Elas não admitem um gênero particular, mas dão origem a diversos gêneros textuais produzidos nesses contextos sociais e que marcam as práticas discursivas estabelecidas nas diversas esferas sociais. (Ibid, 2008, p.155)

A concepção de gêneros do discurso apresentada por Bakhtin ([1979] 1997, p.291) e defendida neste trabalho situa os interlocutores como agentes do discurso ao conferir a eles atitude responsiva ativa diante da significação de um discurso. Se os interlocutores possuem atitude ativa, eles possuem também força intencional na produção dos variados gêneros do discurso, que, consoante esse autor (ibid), estão relacionados à variedade dos escopos intencionais daquele que fala ou escreve.

Tem-se, assim, a concepção social da construção dos gêneros textuais, uma vez que eles se relacionam às necessidades e às intenções daqueles que estão envolvidos nas práticas discursivas em que ocorrem as produções dos enunciados. Desse modo, o enunciado ganha posição relevante na teoria desenvolvida por Bakhtin, uma vez que ele constitui a unidade real da comunicação verbal (Ibid, p.294) que delineia os gêneros do discurso e delimita as características estruturais de cada um deles.

\footnotetext{
O gênero do discurso não é uma forma da língua, mas uma forma do enunciado que, como tal, recebe do gênero uma expressividade determinada, típica, própria do gênero dado. No gênero, a palavra comporta certa expressão típica. Os gêneros correspondem a circunstâncias e a temas típicos da comunicação verbal e, por conseguinte, a certos pontos de contato típicos entre as significações da palavra e a realidade concreta. (BAKHTIN, [1979] 1997, p. 313)
}

Portanto, Bakhtin (ibid) reconhece nos gêneros do discurso as práticas sociais em que se insere o enunciado. A partir dessa percepção, os estudos relacionados ao texto passam a considerar não somente seus aspectos gramaticais, uma vez que o enunciado e as práticas sociais compõem as práticas discursivas presentes em determinado gênero textual. Nas palavras de Marcuschi (2008, p.155), não se pode tratar o gênero do discurso independentemente de sua realidade social e de sua relação com as atividades humanas. 
Nessa mesma compreensão, os gêneros textuais são, conforme Bazerman (2005, p. 32),

fatos sociais sobre os tipos de atos de fala que as pessoas podem realizar e sobre os modos como elas os realizam. Gêneros emergem nos processos sociais em que pessoas tentam compreender umas às outras suficientemente bem para coordenar atividades e compartilhar significados com vistas a seus propósitos práticos.

Sendo assim, os gêneros textuais estão relacionados às práticas sociais diárias específicas de um grupo e são definidos, classificados e modificados historicamente. Isso é ratificado por Miller (1984, p.163) quando a autora defende a natureza sócio-histórica dos gêneros, ao afirmar que eles se referem a categorias discursivas baseadas nas práticas sociais recorrentes e adquirem significado por meio da situação e do contexto social em que foram produzidos, a ponto de constituírem a substância da vida cultural de uma sociedade. Para essa autora, os gêneros retóricos são baseados nas práticas retóricas, ou seja, nas convenções do discurso que uma sociedade estabelece como formas de "ação coletiva" 65 (aspas da autora).

A concepção retórica dos gêneros também compõe o trabalho desenvolvido por Swales (1990, p.46). Esse autor (ibid) compreende que os textos são eventos comunicativos que englobam não apenas o próprio discurso e seus participantes, mas também o papel desse discurso e o meio de sua produção e acolhimento, incluindo suas associações históricas e culturais $^{66}$. A proposta de Swales se compromete com a teoria, a análise e o ensino dos gêneros textuais, sendo que as concepções de comunidade discursiva e propósito comunicativo são pontos centrais para a definição e a caracterização dos gêneros textuais. (HEMAIS \& BIASE-RODRIGUES, 2005, p. 108-109)

Bonini (2002) apresenta o paradigma cognitivo dos gêneros textuais. Conforme esse autor, os gêneros constituem produtos das experiências individuais dos sujeitos (intramental) somadas às questões contextuais vivenciadas por eles (extramental), adotando, segundo Ramos (2007, p.37), paradima enacionista, que entende a cognição não como uma mera representação da realidade, mas resultante de um processo de interação entre os sujeitos e entre esses e o ambiente de inserção.

Posteriormente, Bonini (2007, p. 60-61) passa a investigar a relação entre os gêneros, os eventos comunicativos e as práticas sociais. Neste sentido, esse autor (ibid) propõe que os estudos do gênero alcancem as estruturas sociais que se relacionam diretamente aos eventos comunicativos. Assim, faz-se necessário que elementos como o suporte, o lugar que o gênero ocupa no suporte, os enunciadores envolvidos e as circunstâncias em que os sujeitos se

\footnotetext{
65 Tradução própria.

66 Tradução própria.
} 
encontram sejam estudados a fim de compreender as práticas sociais relacionadas à produção e à circulação de gêneros em determinada sociedade e em determinado momento histórico.

A concepção de gênero apresentada por Bronkart (2009, p. 140) encontra-se no viés do interacionismo sociodiscursivo. Os gêneros são, para ele (ibid), construídos pelo acúmulo de processos individuais que se modificam permanentemente e, por essa razão, possuem natureza dinâmica e histórica. O conhecimento dos gêneros que circulam socialmente define o espectro das ações de linguagem possíveis na sociedade, pois o processo de apropriação de gêneros molda a pessoa humana. (Ibid, p.103)

A respeito da relação estabelecida entre os gêneros textuais e as atividades de ensino, Schneuwly \& Dolz (2004, p. 63-64) compreendem ser através dos gêneros que as práticas de linguagem materializam-se nas atividades dos aprendizes. Por essa razão, torna-se fundamental um trabalho com gêneros textuais que transcenda aqueles já cristalizados no contexto escolar, presentes nos materiais didáticos e socialmente reconhecidos. É preciso, pois, que os gêneros textuais escolhidos reflitam as práticas sociais de modo que os alunos se apropriem de suas formas linguísticas e discursivas.

No contexto escolar, os gêneros textuais devem ser considerados como um instrumento semiótico complexo [...] que permite, a um só tempo, a produção e a compreensão de textos (SCHNEUWLY, 2004, p.24). Por essa razão, a escolha do gênero precisa acontecer em função da definição dos parâmetros que irão guiar a ação pedagógica do professor.

Assim, foi essencial, para o desenvolvimento desta pesquisa, que os alunos percebessem as peculiaridades comuns a cada gênero textual trabalhado durante as aulas (vide Anexo II e apêndices I, II, III e IV), pois a apropriação deles constitui mecanismo fundamental de socialização e inserção prática nas atividades comunicativas humanas (BRONCKART, 2009, p.103). A concepção de texto como prática social influenciou o processo de seleção dos gêneros textuais que seriam trabalhados nas aulas desenvolvidas pela professora-pesquisadora. Era necessário que tais gêneros refletissem as práticas sociais dos alunos e ampliassem suas percepções a respeito da crise hídrica - tema que estava sendo abordado naquela turma em razão do projeto interdisciplinar de que a turma estava participando (vide item 3.5).

Por conseguinte, ler, compreender, analisar e produzir gêneros textuais relacionados às práticas sociais dos alunos, além de conhecer outros que não se relacionam diretamente com suas realidades, amplia a percepção dos estudantes acerca dos traços linguístico-discursivos 
presentes nos textos e transforma a aula de Leitura e Produção de Textos em evento de letramento social, escolar, científico, tecnológico, entre outros letramentos múltiplos ${ }^{67}$.

Como exemplo do trabalho com a compreensão dos gêneros textuais, serão utilizados os excertos 17, 18 e 19 como forma de apresentar como foi estabelecido o primeiro contato dos alunos com alguns dos gêneros textuais que compuseram as atividades realizadas durante o processo de geração dos dados. Na primeira aula, a professora-pesquisadora aplicou a atividade de leitura individual e coletiva de três charges (Apêndice I) e, ao apresentar a proposta de trabalho aos alunos, no início da aula, contextualizou o gênero textual charge, conforme pode ser visto no excerto 17.

\section{Excerto 17 - Aula 01}

01 Professora: /.../ nós temos três textos, né, três charges. Vocês já ouviram falar sobre charge? O 02 que que é charge? Que gênero textual é esse? ((silêncio e inferências realizadas individualmente 03 pelos alunos sem socialização))

04 Aluna 5: (Tirinhas)

05 Professora: Ele se aproxima realmente de tirinhas... Oi?

06 Aluna 6: Pedaços pequenos?

07 Professora: Pedaços pequenos de textos. Ele é pequeno. A gente olha, a gente lê e logo a gente já 08 tem uma visão daquele texto. O objetivo da charge é esse: ela combina, vocês observem aí, não 09 tem só o texto escrito. Eu tenho também o quê?

10 Aluna 8: Desenhos.

11 Professora: Desenhos. ((voltando-se para aluna))

12 Aluna 9: Ilustrações.

13 Professora: Ilustrações. ((voltando-se para aluna)) Imagens. É a combinação das imagens, das 14 expressões dos personagens daquela charge que me fazem compreender o texto por inteiro.

De modo intencional, a professora-pesquisadora questionou os alunos acerca do conhecimento prévio que eles possuíam a respeito do gênero textual charge, que compôs a atividade aplicada, pois imaginava que muitos estudantes não conheciam esse gênero, ou até podiam ter tido contato com ele, mas sem ter consciência de suas particularidades. $\mathrm{O}$ reconhecimento do gênero textual, antes de iniciar a atividade de leitura e compreensão textual, é de fundamental importância, porquanto o estudante, ao reconhecer as características de cada gênero, garantirá mais fluidez no processo de leitura e na produção de inferências.

Bazerman (2007, p.30) chama atenção para a necessidade de os professores evocarem o interesse dos alunos por gêneros que estão presentes em seus cotidianos, mas também para a apresentação de gêneros textuais desconhecidos por eles, a fim de envolvê-los em situações discursivas novas.

\footnotetext{
${ }^{67}$ Os conceitos a respeito de letramento e sua aplicabilidade no contexto desta pesquisa serão tratados no capítulo 05 .
} 
O gênero é uma ferramenta para descobrir os recursos que os alunos trazem consigo, ou seja, os gêneros que trazem de sua formação e de sua experiência na sociedade. É também uma ferramenta para definir os desafios que levarão os alunos a novos domínios até então não explorados por eles (...). (...) nossa escolha estratégica de gêneros para trazer para sala de aula pode ajudar a introduzir os alunos em novos territórios discursivos, um pouco mais além dos limites de seu habitat linguístico natural. (BAZERMAN, 2007, p.31)

Posteriormente, no momento da correção das questões referentes à atividade exposta no Apêndice I, a professora retomou a discussão sobre o entendimento do gênero textual charge e pormenorizou os modos de realizar sua leitura.

\section{Excerto 18 - Aula 01}

01 Professora: /.../ Ok. Então agora, aí vem a questão número quatro... e eu como eu disse, né, 02 vocês vão relacionar essas charges. /.../ "Qual é a característica do gênero textual charge"? A 03 gente falou bem no início da aula, né? É... Mas vamos rememorar, então... Quais as 04 características da charge? O que ela tem?

05 ((vozes sobrepostas))

$06 \quad$ l...l

07 Professora: Vamos tentar pensar primeiramente, antes da crítica, o que ela tem de texto. Como

08 ela se organiza? Como ela é... como... o que há de comum nessas três charges, eu tenho o que 09 nelas?

10 ((vozes sobrepostas))

11 Professora: Eu tenho imagens, desenhos, e...

12 Aluna 3: $E$ as falas, eu tenho as falas.

13 Professora: Eu tenho a linguagem verbal e a não verbal /.../. E essa linguagem verbal e não 14 verbal, elas são combinadas de modo que, se eu só ler a, a... o fra/o que está escrito aí e não olhar 15 a imagem, vai estar incompleto.

[Aluna 1: Muito geral.

[Professora: Não vai ser tão clara. Agora, 18 se eu consigo aliar a linguagem verbal... Aquilo que está escrito com aquilo que está desenhado, 19 né... E a charge, ela normalmente tem muitos detalhes. Não é só aquilo que está em evidência. 20 Observem que os personagens aí sempre estão em evidência, mas se a gente não olhar o que está 21 ao redor deles

22 [Aluno 7: Não dá sentido, né?

29 Professora: De não enxergar. Então, é um texto que parece ser simples, mas não é. Alguns são 30 até mais complexos do que textos/.../

Nesse excerto, a professora-pesquisadora entrou em detalhe a respeito das características do gênero textual trabalhado a fim de que os alunos percebessem suas particularidades e analisassem o texto em sua totalidade. Como Marcuschi (2010, p.38) 
afirma, ainda são poucos os casos de tratamento sistemático dos gêneros pela escola, pois é necessário considerar que os gêneros são modelos comunicativos, que servem, muitas vezes, para criar expectativa no interlocutor e prepará-lo para determinada reação. A professorapesquisadora encaminhou os alunos para a reflexão das particularidades discursivas presentes em uma charge para que eles percebessem que, por mais que parecesse ser um texto simples em razão de sua curta extensão, nele havia elementos verbais e não verbais que precisavam ser observados com atenção para que o entendimento não fosse prejudicado.

O mesmo aconteceu na aula 04 quando a professora introduziu o texto 01 (boletim informativo da Rádio Nova Brasil FM), que tratava da necessidade de economia de água, em razão da crise hídrica pela qual o país passava naquele momento.

\section{Excerto 19 - Aula 04}

01 Professora: E a "Nova Brasil FM", /.../ começou a publicar o que nós chamamos de boletim 02 informativo, que é um texto que normalmente passa despercebido aos nossos ouvidos, porque 03 normalmente a gente liga o rádio querendo escutar música /.../

\section{I.../}

05 Professora: É aí, rápido né, não tem nem dois minutos, ele é rápido, o boletim informativo ele 06 tem essa característica, ele é rápido, porque tudo no rádio e na TV também tem que ser

07 cronometrado, não pode ser muito longo, tem que ser no seu tempo devido é:::, mas ele passa

08 uma mensagem interessante, se a gente observar ele tem início, meio e fim, né? Ele é como um

09 texto mesmo, né? E ele introduz dizendo o quê? Como que ele começa falando? O quê? Sobre o 10 quê? /.../

11 Aluna 01: Do desperdício da água.

12 Professora: Do desperdício da água, e ele fala também que é preciso desenvolver.

13 Aluna 02: ( ).

14 Professora: Isso, que é preciso desenvolver o quê, gente? Em relação ao desperdício da água?

15 Alunos: Conscientização.

Por meio da discussão dos principais conceitos de gêneros textuais que embasam este estudo e dos exemplos apresentados nos excertos 17, 18 e 19, fica evidente que o tratamento dado aos gêneros textuais em sala de aula necessita ser reflexivo e sistemático (MARCUSCHI, 2010). Não é suficiente apenas oferecer uma diversidade de textos aos alunos, se o docente não os relaciona com aquelas práticas discursivas já vivenciadas e com outras que eles poderão vivenciar. É necessário tratar, em sala de aula, não somente do tópico discursivo do texto, mas das características textuais e discursivas próprias de cada gênero.

\subsection{A multimodalidade no processo inferencial}

Com o intuito de discutir sobre o caráter multimodal dos textos selecionados pela professora-pesquisadora e pela professora regente, serão discutidos conceitos introdutórios 
referentes à Semiótica Social (VAN LEEUWEN, 2005) e à Gramática do Design Visual, doravante, GDV. (KRESS \& VAN LEEUWEN 2006 [1996])

Nesta subseção, esses conceitos serão apresentados de forma breve, por não constituírem o foco principal deste trabalho. Todavia, desconsiderá-los consistiria em negligência, uma vez que todos os textos, os verbais e os não verbais, presentes no discurso oral e no escrito, são multimodais; e a percepção da diversidade de recursos linguísticos e imagéticos contribuiu no processo de construção de inferências dos alunos durante as atividades de leitura e de compreensão textual.

Bezemer \& Jewitt (2010, não paginado) indicam que todas as formas de comunicação são moldadas por meio dos usos históricos, sociais e culturais para realizar suas funções sociais $^{68}$. Desse modo, os significados realizados por qualquer modo de comunicação (oral, escrito, visual) estão sempre entrelaçados com os significados feitos com outros modos e colaboram para que ocorra um evento comunicativo. Essa interação produz o significado, e a multimodalidade concentra-se em um processo de construção de significados, sendo um processo no qual as pessoas fazem escolhas a partir de uma rede de alternativas, selecionando um significado modal em detrimento de outro (ibid) ou considerando ambos os significados e enfatizando aquele que mais se destacou.

Assim, a extensão espacial de um gesto, as formas de entonação da voz e a direção do olhar constituem recursos que contribuem na construção de sentidos. Ressalte-se que a Sociolinguística Interacional e as demais áreas que utilizam orientações da etnografia para a construção de suas pesquisas consideram, em seus estudos, todos os recursos semióticos que compõem as interações sociais para compreender os sentidos partilhados pelos colaboradores de pesquisa.

Van Leeuwen (2005, p.03) entende os recursos semióticos como

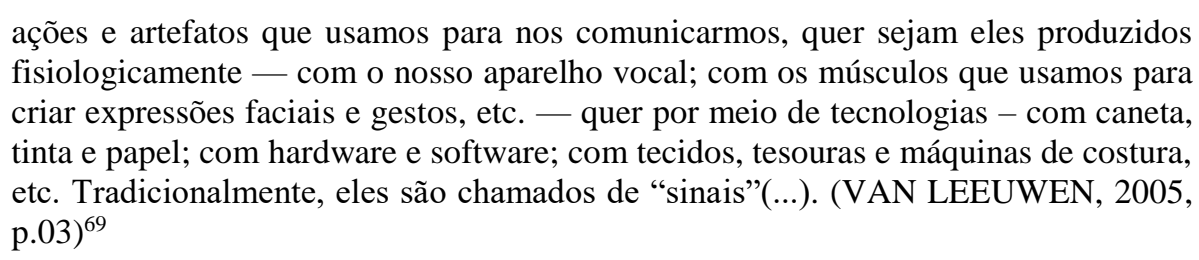

Isso significa que todos os textos são multimodais, desde a diagramação, as cores, as figuras, o tipo de papel (no caso do texto escrito) ou até como as pessoas se comportam nos

${ }^{68}$ Tradução própria.
${ }^{69}$ Tradução própria. 
textos orais (gestos, entonação de voz, expressões faciais) pode ser chamado de multimodalidade (FERRAZ, 2011, p.45), uma vez que todos os textos são produzidos e recebidos por meio de recursos semióticos variados. Esses recursos precisam ser considerados no processo inferencial para que a compreensão textual ultrapasse as estruturas linguísticas e alcance as práticas sociais representadas pelo texto.

Sobre a importância da Semiótica Social nos estudos linguísticos, Santos \& Pimenta (2014, p.300) entendem que, dentro dessa perspectiva, a linguagem constitui

\begin{abstract}
um tipo de comportamento social, ou seja, ela tem uma "função" (aspas das autoras) que é construída a partir das interações humanas e está organizada em "sistemas" contextualmente sensíveis. Assim, o uso da linguagem está revestido por significados potenciais, associados a situações específicas e influenciados pela organização social e cultural.
\end{abstract}

A Gramática do Design Visual reúne os principais fundamentos das teorias da Linguística Sistêmico-Funcional (LSF) desenvolvidas por Halliday \& Matthiessen (2004) e Halliday \& Hasan (1976), bem como as da Semiótica Social (VAN LEEUWEN, 2005). Assim sendo, a multimodalidade deve ser entendida como característica intrínseca aos textos e, por essa razão, precisa ser levada em conta pelos professores ao realizarem quaisquer atividades de compreensão textual.

Ao introduzirem a GDV, Kress e van Leeuwen (2006[1996], p.03) deixam claro o seguinte:

(...) 'nossa' (aspas dos autores) gramática é uma gramática bastante geral de design visual contemporâneo na cultura "ocidental" (aspas dos autores), um relato dos conhecimentos e práticas explícitas e implícitas em torno de um recurso, que consiste dos elementos e regras subjacentes a um formulário específico da cultura de comunicação visual. (KRESS \& VAN LEEUWEN 2006 [1996], p.03) ${ }^{70}$

Kress e van Leeuwen (2006[1996], p.05) acreditam que, assim como as línguas constituem construções sociais, a linguagem visual dominante é resultado da cultura de globalização vivida pela sociedade. Por essa razão, há de se ter cuidado, ao analisar imagens, em considerar as condições sociais, culturais e históricas sob as quais elas se inscrevem. Esses autores (ibid, p.33-34) defendem que as escolas precisam repensar a inclusão da comunicação visual nos currículos de alfabetização, pois a escrita continua sendo privilegiada e a multimodalidade de textos escritos tem, de modo geral, sido ignorada, seja em contextos de

\footnotetext{
70 Tradução própria.
} 
ensino, na teorização linguística ou no senso comum. Por essa razão, hoje, na era da multimídia, a multimodalidade necessita ser percebida e abordada. (Ibid, p.41)

Desse modo, a multiplicidade de semioses presentes nos textos verbais e não verbais passa a ser estudada por meio das teorias relacionadas à Semiótica Social, à LSF e à GDV, e os estudos linguísticos voltados para essas áreas passam a considerar os aspectos imagéticos e composicionais de um texto, ou seja, a construção de sentidos deve ser o resultado de um princípio integrador do uso de vários recursos semióticos que conferem significado ao texto (VIEIRA, 2015, p.48). Logo, o formato da letra, a fonte, a cor e o tamanho escolhidos; o tipo de suporte selecionado para divulgação do texto; a organização dos participantes dentro de um enquadre e a sobreposição de um sobre o outro na imagem; assim como a escala de cores fortes ou fracas utilizadas, representam traços semióticos que compõem o quadro multimodal do texto.

Nessa perspectiva, quando o professor reconhece os elementos multimodais presentes nos textos que utiliza em suas aulas, espera-se que as interações face a face realizadas com seus alunos, durante as atividades de compreensão textual, sejam guiadas por ele sob a ótica de que o texto possui muito mais elementos a serem considerados além das estruturas linguísticas já consagradas.

Sobre a abordagem realizada pela professora-pesquisadora a respeito dos aspectos multimodais presentes nos textos trabalhados, tem-se, como exemplo, a discussão sobre texto O Fundo do Poço, da revista Super Interessante (Anexo II). Na aula 04, a professorapesquisadora apresentou, por meio da projeção de imagens do computador, o gênero textual infográfico (Figura 23), que fazia parte dessa reportagem sobre a crise hídrica no estado de São Paulo. O objetivo do infográfico era mostrar a queda do nível de água no Sistema Cantareira, reservatório que fornece água para uma grande parte do estado de São Paulo. O excerto 20 ilustra como a professora-pesquisadora apresentou esse gênero textual para os alunos, caracterizando-o e mostrando sua funcionalidade para a compreensão do assunto abordado na reportagem. 
Figura 23 - Infográfico sobre o nível de água no Sistema Cantareira.

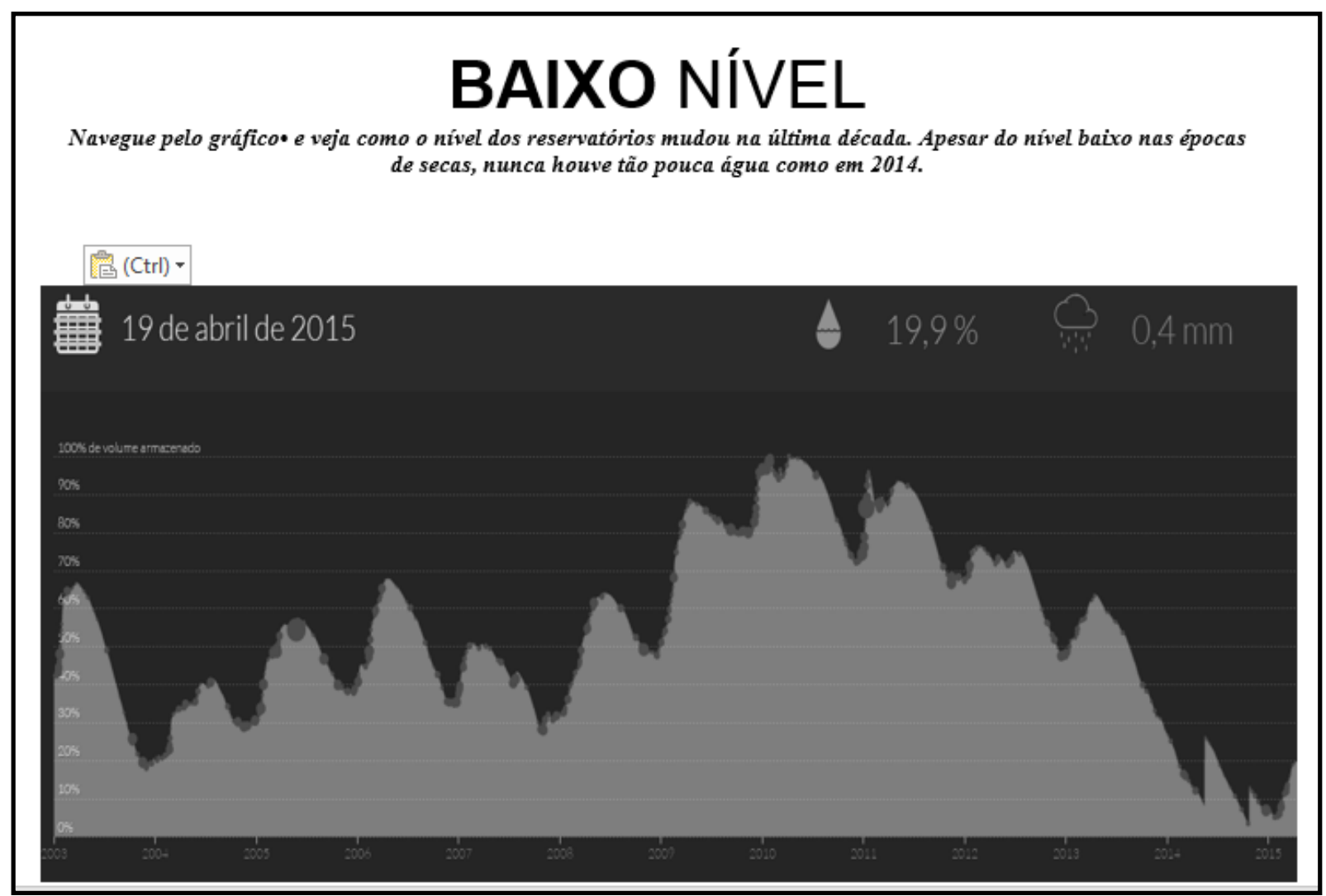

Fonte: http://super.abril.com.br/crise-agua/ofundodopoco.shtml. Acesso em 20/03/2015.

\section{Excerto 20 - Aula 04}

01 Professora: Na última página do texto de vocês, tem um "infográfico", abaixo, que tem um título

02 de baixo nível, né, "navegue pelo gráfico e veja como é o nível dos reservatórios e veja como o

03 nível dos reservatórios mudou na última década apesar do nível baixo nas épocas de secas, nunca

04 houve tão pouca água como em 2014" ((lendo a informação que precedia o infográfico)). Como

05 não deu para fazer uma cópia colorida pra cada um, a cópia tá em preto e branco e fícou muito

06 pequeno, mas o que eu quero é que vocês percebam que isso aqui é um gráfico é... a leitura de

07 gráfico é uma leitura muito importante, que muita gente tem dificuldade e, às vezes, até ignora o

08 gráfico. No momento que está lendo uma notícia, lê o texto da notícia, mas não lê o gráfico. E, às

09 vezes, o gráfico traz informações mais importantes que a própria notícia, tá, ele complementa a

10 notícia, então, por que eu trouxe aqui? Porque esse infográfico ele é muito interessante /.../

11 Esse é o infográfico, não sei se vocês percebem que quando eu mudo o cursor aqui

12 ((movimentando o cursor do notebook)) ele se movimenta, tá vendo? Então, olha que interessante

13 aqui nós temos, no início do infográfico, /.../ o percentual do nível de água e aqui/.../ os anos. Eu

14 começo em 2003 e vou até 2015, o ano em que nós nos encontramos. E aqui a gente percebe o

15 nível de água, que estava aqui e aqui, olha ele sobe e desce, sobe e desce, sobe e desce, sobe e

16 desce e ele chegou a um nível em determinado momento do ano passado que foi crítico,

17 observem qual é o menor nível aqui, gente? É aqui, não é?

O excerto 20 expressa um momento da quarta aula em que a professora-pesquisadora explicou aos alunos a maneira de realizar a leitura de um infográfico, gênero textual 
emergente, que necessita da mobilização não apenas de recursos intelectuais, mas de recursos tecnológicos para a realização da leitura. Marcuschi (2004, p. 13) compreende que os gêneros emergentes estão relacionados com as novas tecnologias e que eles reúnem, num só meio, várias formas de expressão, tais como texto, som e imagem, o que lhe dá maleabilidade para a incorporação simultânea de múltiplas semioses interferindo na natureza dos recursos linguísticos utilizados.

Há também outro momento, na aula 05, em que a professora-pesquisadora destacou (Excerto 21) outro aspecto multimodal desse mesmo texto, que diz respeito à imagem (Figura 24), que explicitou como se encontrava, então, o volume útil do reservatório de água do Sistema Cantareira.

Figura 24 - Volume útil do reservatório do Sistema Cantareira.

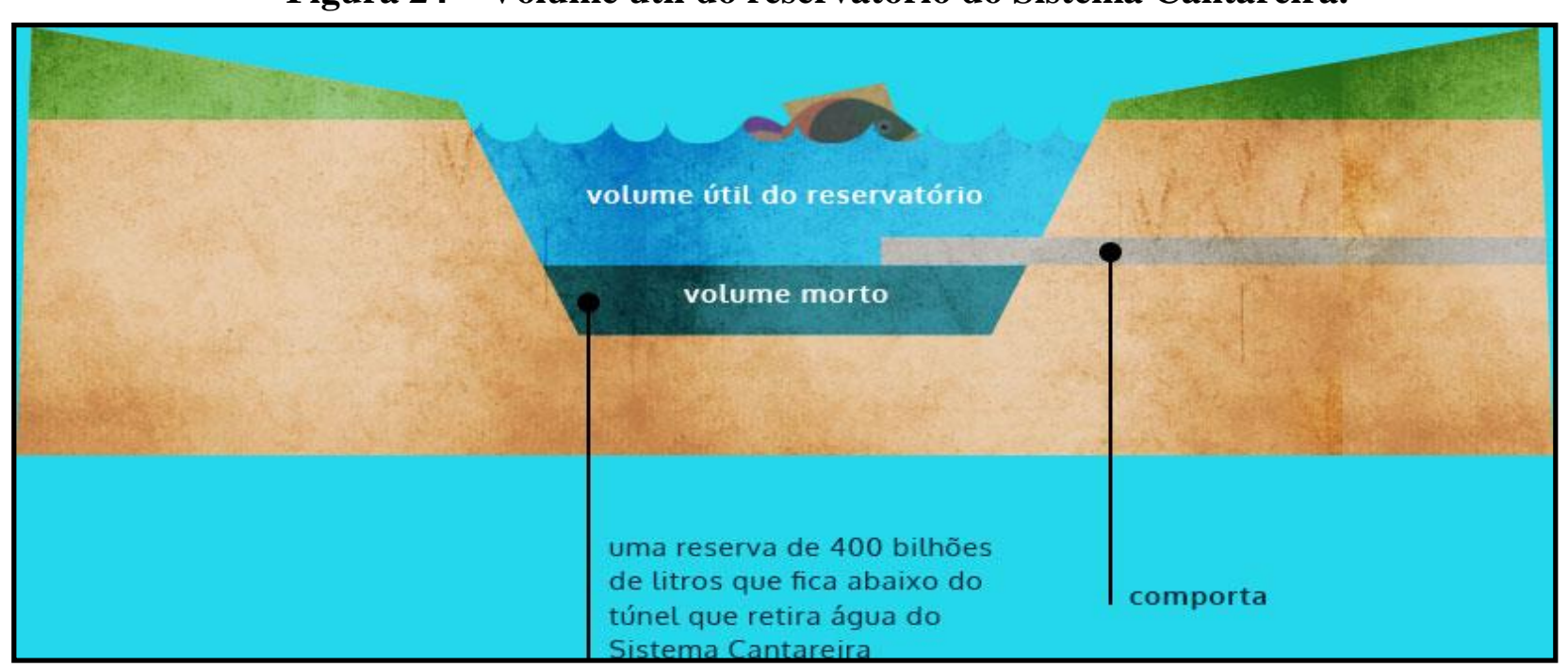

Fonte: http://super.abril.com.br/crise-agua/ofundodopoco.shtml. Acesso em 20/03/2015.

\section{Excerto 21 - Aula 05}

01 Professora: 11,8 milhões de habitantes. E aí cada habitante usa muitos litros de água, se a gente 02 multiplicar aí a gente vai ver que não vai dar pra todo mundo.

03 Aluna 04: Você viu que, eu vi no jornal hoje meio-dia que tava falando a respeito/sobre isso que

04 a Cantareira/que o pouco de água que juntou por causa da chuva, né, já tá secando novamente,

05 assim tava (( )) aí hoje tava passando no jornal falando.

06 Professora: Em São Paulo tá, tá há muito tempo sem chover, aqui nós temos, então, gente uma 07 explicação, um desenho explicativo sobre o volume morto, o que seria o volume morto, aqui? Eu 08 tenho, né, o sistema Cantareira e aqui nós temos todo o espaço de reserva de água, o volume 09 morto é uma reserva de água exatamente para esses casos de exceção, só que a gente percebe que 10 ele é previsto mais assim como uma situação à parte não como um estado inteiro que está em 11 crise, que não tem água, e a gente percebe que esse volume morto ele começou a ser usado, eles 12 começaram a bombear água, porque é muito profundo tem que bombear pra água subir, mas 13 mesmo assim não foi suficiente/.../ 
Sobre o trabalho com os textos multimodais em sala de aula, Silvestre (2015, p.95) assegura que a escola ainda privilegia os aspectos verbais do texto, e, para ela, essa instituição social ainda é compreendida como aquela que mantém o suporte ilustrativo da linguagem verbal (Ibid). Sobre essa afirmação da autora de que a escola só tem se ocupado com o texto verbal, é preciso considerar que, mesmo na perspectiva tradicional, existem muitas semioses nos materiais didáticos elaborados e/ou utilizados por essa instituição como, por exemplo, nos materiais de artes visuais ou cênicas, nas fórmulas das ciências exatas ou nas figuras geométricas da matemática. Os livros didáticos de história e geografia, há muito tempo, já trazem imagens, assim como os livros de biologia e outras áreas do saber. Na verdade, é preciso que haja preocupação com os modos como os professores têm utilizado essas imagens. Será que realmente há um processo de leitura colaborativa do texto não verbal que considere essas múltiplas semioses?

De fato, os aspectos visuais sempre integraram os textos verbais, uma vez que todo texto é multimodal, e o homem, desde os tempos mais primórdios, sempre utilizou desenhos para imprimir seus modos de vida. Exemplos disso são os diversos sistemas de escrita que possuem bases imagéticas, como o alfabético.

Todavia, há de se considerar que, no mundo pós-moderno, os textos estão cada vez mais compostos por diversas semioses e passam a circular em uma velocidade muito maior. Silvestre (2015, p.99) nomeia de ressemantização, quer dizer, uma mutação semântica de um estado "ser literato" para um processo em desenvolvimento de "construir-se literato"71 (aspas da autora), em outras palavras, o enfoque deixa de ser o conhecimento para passar a ser a atividade (SILVESTRE, 2015, p.99). Ou seja, é preciso letrar-se constantemente a fim de acompanhar a renovação dinâmica da leitura dos gêneros emergentes, que surgem, ganham força e tornam-se obsoletos em curtos espaços de tempo.

É necessário, pois, no ambiente escolar, considerar a diversidade de gêneros que surgem e desaparecem rapidamente nesta era imagética vivenciada pela sociedade pósmoderna, de modo que esses textos possam figurar nas atividades de leitura.

O processo de construir-se literato, defendido por Silvestre (2015, p.99), pode ser entendido, no contexto deste trabalho, como toda atividade de construção colaborativa do sentido de textos multimodais. O Excerto 22 exemplifica, mais uma vez, o processo de construção colaborativa de sentidos para o texto 07 .

$71 \mathrm{O}$ termo literato (Português Europeu), utilizado pela autora, equivale à palavra letrado, no Português Brasileiro. 


\section{Texto 07}

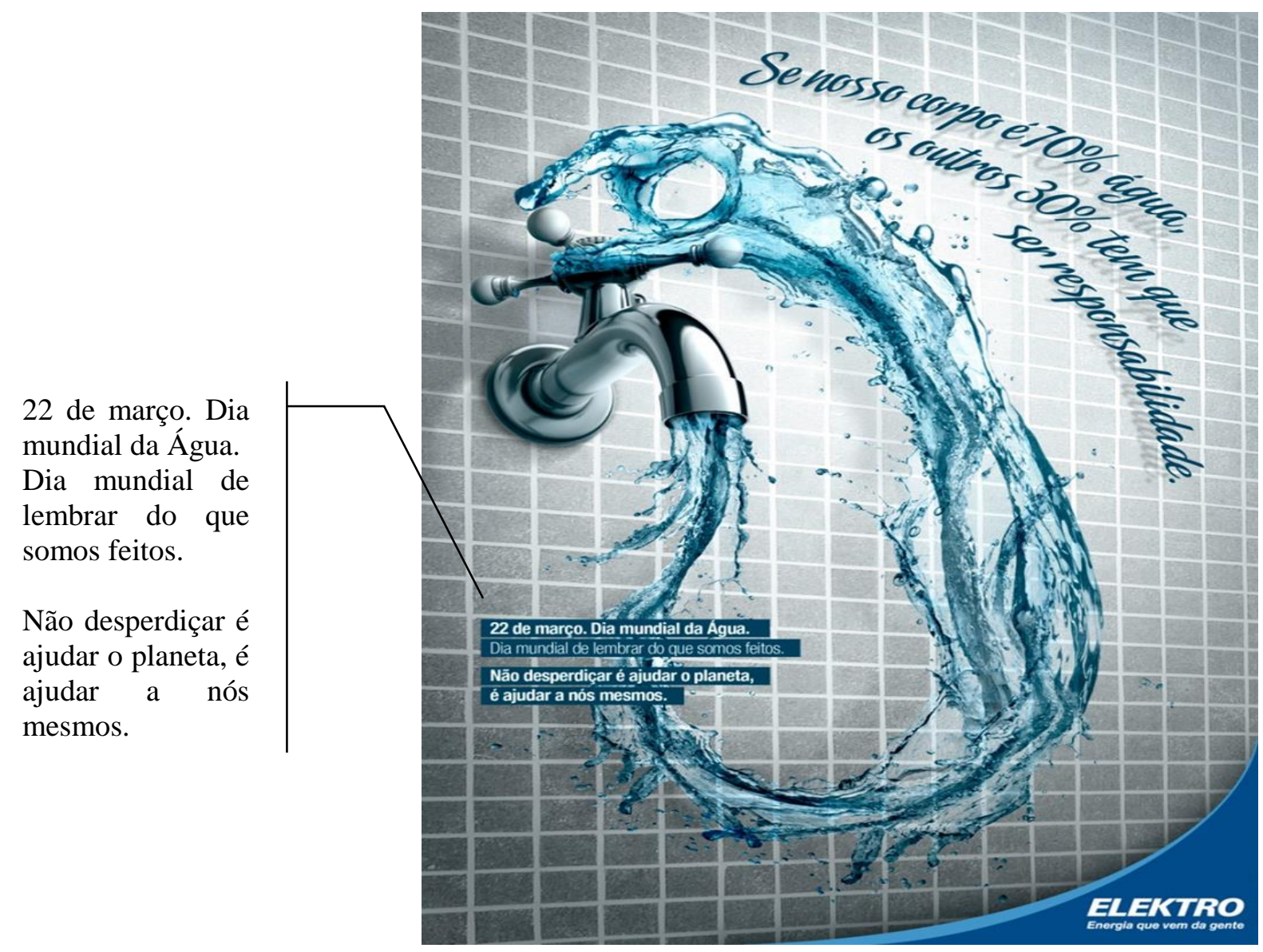

Fonte: http://www.maiusculo.com.br/wp-content/uploads/2012/08/Dia-d_agua.jpg. Acesso em 24/03/2015.

\section{Excerto 22 - Aula 04}

01 Professora: /.../ o primeiro anúncio, o que vocês entendem com essa imagem?

02 Aluna 01: A torneira derramando água.

03 Professora: A torneira?

04 Aluna 02: Derramando água.

05 Professora: Derramando água. Estragando água?

06 Aluna 03: (eu acho) que a água mesmo tá desligando a torneira.

07 Professora: A água mesmo está desligando a torneira.

08 Aluna 04: É mesmo.

09 Professora: Essa água, quando a gente abre a torneira, né, a lei da gravidade né? A água cai né?

10 Aluna 05: Uhum.

11 Professora: Mas essa, nesse anúncio publicitário há uma, há algo diferente, não há o segmento

12 da lei da gravidade. O que ocorre? A água está subindo.

13 Aluna 06: Ela faz um movimento que...

14 Professora: Ela faz um movimento, o quê? Que é isso aqui?

15 Aluna 06: Circular.

16 Professora: Que eu estou fazendo? Circular. Isso quer dizer que a água que sai da torneira ela 17 tem o quê?

18 Alunas: Voltar ((várias alunas)).

19 Professora: Né? Então essa propaganda, quando a gente olha, a gente já percebe assim, esse

20 impacto, essa mensagem, a água que sai da sua torneira ela tem precisa voltar pra sua torneira. $\mathrm{E}$ 
21 como fazer isso? Agora sim eu vou colocar um pouquinho da lupa, que está escrito aí com letras

22 bem, bem, com letras muito pequenas tá, tá escrito o seguinte, e aí eu vou ler pra vocês, porque

23 ainda tá pequeno. "Se nosso corpo é $70 \%$ água, os outros $30 \%$ tem que ser responsabilidade."

24 Olha que interessante?

Todos os exemplos apresentados e as teorias discutidas levam à compreensão de que textos presentes nas aulas precisam ser reconhecidos como multimodais, e essa percepção leva o docente a conduzir seu trabalho com práticas que despertem nos alunos a percepção das múltiplas semioses presentes no texto a fim inseri-los no processo de construção do letramento crítico.

\subsection{O processo de construção dos sentidos dos textos durante atividade escrita}

Nesta subseção, serão apresentadas as análises das inferências realizadas pelos alunos durante a primeira atividade escrita de leitura e de compreensão textual aplicada no segundo encontro, ocorrido no dia 10 de abril de 2015. Todas as 27 atividades, contendo quatro questões cada (Anexo III), foram lidas e analisadas pela professora-pesquisadora compreendendo as inferências como resultado não apenas de processos mentais, mas das ações sociais vivenciadas pelos sujeitos e dos conhecimentos prévios construídos por eles ao longo da vida.

Por essa razão, serão discutidos, neste tópico, os conceitos referentes à Semântica Argumentativa (KOCH, 2009c e VOGT, 1980), ratificando a compreensão de que todo texto possui argumentatividade, ou seja, posicionamentos que influenciam o leitor e o convidam a também construir um posicionamento, bem como os estudos da compreensão textual como processo interativo. (KLEIMAN, [1989a] 2009 e 1989b; MARCUSCHI, 2008; e KOCH e ELIAS, 2006)

\subsubsection{Texto e argumentatividade}

Nas concepções defendidas neste trabalho, a significação do texto deve ser entendida como resultado das relações sociais estabelecidas entre os interagentes, somadas aos seus conhecimentos prévios adquiridos formal e informalmente (KLEIMAN, [1989a] 2009, p.1320). Benveniste ([1974] 2006, p.81) deixa bem clara a diferenciação entre forma e emprego da língua. A primeira volta-se para a descrição e a segunda, para a enunciação. A segunda definição, claro, é a mais condizente com este trabalho, pois, conforme Benveniste, entendese por enunciação o "funcionamento da língua" e a transformação da "língua em discurso". 
A enunciação supõe a conversão individual da língua em discurso. Aqui a questão - muito difícil e pouco estudada ainda - é ver como "sentido" se forma em "palavras", em que medida se pode distinguir entre as duas noções e em que termos descrever sua interação. É a semantização da língua que está no centro deste aspecto da enunciação, e ela conduz à teoria do signo e à análise da significância. (BENVENISTE ([1974] 2006, p.83)

Nesse sentido, os interagentes se apropriam da língua por meio da enunciação e é pelo discurso que se processam os sentidos, pois eles são produzidos e interpretados socialmente. A língua em uso, desse modo, estabelece uma relação discursiva com o parceiro, seja este real ou imaginário, individual ou coletivo (ibid, p.85). Todavia, como será apresentado posteriormente, as atividades de compreensão textual realizadas individualmente pelos colaboradores de pesquisa revelam que o percurso entre a forma e o enunciado nem sempre ocorre da forma como deveria acontecer, ou seja, os alunos ainda ficam presos à estrutura textual por não possuírem conhecimentos prévios que lhes permitam prosseguir a caminhada rumo à compreensão do enunciado.

Vogt (1980, p.72-73) retomou a ideia de Benveniste quando indicou ser necessário o desenvolvimento de pesquisas pragmáticas que olhassem para as imbricações de diferentes sistemas de representação. Para esse autor (ibid), esse estudo se relaciona a uma macrossintaxe das línguas naturais, que consiste em região teórica de convergência da unidade de estrutura e da unidade de experiência, a que chamou de intervalo semântico. Trata-se assim, $[d]$ a região das significações intermediárias entre o dizer e o não dizer, local de explicitações não só dos processos de reprodução das significações, mas também de sua produção (ibid, p.73). Houve necessidade, portanto, de um campo da Linguística que se ocupasse da investigação dos sentidos produzidos pelo texto, considerando suas questões internas e externas.

Como área de estudo, tem-se a Semântica Argumentativa, subárea que auxiliou na análise das inferências produzidas pelos colaboradores desta pesquisa, pois procura compreender como o discurso dos enunciados, sejam eles orais ou escritos, são orientados pela argumentatividade. Assim, Koch (2009b, p.17) afirma que o discurso neutro é um mito, pois ele está repleto de ideologias, e os leitores precisam alcançar os sentidos compartilhados por um texto por meio do processo de compreensão.

Nesse sentido, o discurso presente no texto, para que seja bem estruturado e lhe permita atingir seu objetivo, necessita de progressão e coerência, além de todos os elementos propostos por Beaugrande e Dressler (1981), os quais conferem textualidade (tessitura) ao texto. A argumentação constitui, portanto, atividade estruturante de todo e qualquer discurso, 
já que a progressão e a coerência ocorrem exatamente por meio das "articulações argumentativas”. (KOCH, 2009b, p.21)

Além dos elementos responsáveis pela tessitura do texto, há as influências sociais na construção textual e na produção dos sentidos, pois é no campo social que os limites da região ideológica reproduzem e combinam as imagens do enunciador e do destinatário (VOGT, 1980, p.92-93). Por essa razão, as significações que assim se produzem têm o limite das convenções sociais que as autoriza. (Ibid)

Os textos resultam das vivências dos sujeitos, bem como das relações que eles estabelecem com o meio social no qual estão imersos, de modo que os conhecimentos prévios são constituídos pelos artefatos culturais (TOMASELLO, [1999] 2003) construídos e partilhados pelos sujeitos.

Além disso, o argumento não consiste em uma prova para que as condições de verdade se realizem ou sejam refutadas, mas é considerado como uma razão que o locutor fornece ao seu interlocutor/leitor para que este aceite uma conclusão (GUIMARÃES, 1995, p.50). A argumentação, assim, faz parte das mais antigas práticas dos seres humanos e norteia as relações sociais, uma vez que os sujeitos sempre vivenciam o processo de convencerem uns aos outros. Portanto, afirma-se que a argumentatividade integra as atividades discursivas, pois permite aos sujeitos acesso a um conhecimento estabelecido. (Ibid, p.78)

A argumentação é, portanto, a direção tomada pelo dizer, é conduzir um texto para seu futuro, para seu fim (final/finalidade) (Ibid). E isso não significa que a orientação argumentativa do interagente diga respeito às intenções que ele possui, mas indica a direção que determinado texto produzido por ele possui, para onde ele aponta. Reconhecer o teor argumentativo do texto é alcançar sua unidade de significação (VOGT, 1980), e só se chega à compreensão do texto por meio de processo interativo, que inclui a ativação de diversos conhecimentos. É o que será explicitado mais adiante.

\subsubsection{A compreensão textual como processo interativo}

Conforme Kleiman (1989b, p.38), o processo de leitura se realiza de maneira interativa de modo que o sujeito-leitor estabelece relações com o texto por meio da ativação de conhecimentos ortográficos, sintáticos-semânticos, pragmáticos, enciclopédicos. Esses conhecimentos são utilizados não de maneira hierárquica (um após o outro, do mais simples para o mais complexo ou vice-versa), mas, no modelo de leitura pela interação, 


\begin{abstract}
cada um dos níveis de conhecimento pode servir de input, a qualquer momento, para um outro nível, e, quando um nível de análise é impedido, por falhas na "fonte" de conhecimento, outras fontes fornecem maneiras alternativas de determinar o significado. (....) Nessa definição, tanto o sujeito como o texto delimitam o leque de possíveis leituras de um texto: não há abertura total, porque hipóteses de leitura devem ser verificadas mediante a depreensão de aspectos formais, nem há apenas uma leitura, porque cada sujeito impõe a sua estrutura de conhecimento ao texto. (KLEIMAN, 1989b, p.38)
\end{abstract}

Do mesmo modo, Marcuschi (2008, p.256) defende que a compreensão textual deve ser entendida como processo que possui, pelo menos, quatro características, a saber:

(1) Estratégia: a compreensão não é uma atividade com regras formais e lógicas, com resultados automáticos, mas há nela uma ação estratégica, otimizada com escolha de alternativas mais produtivas. É por essa razão que as inferências mais comuns não são as lógicas e sim as pragmáticas, semânticas ou cognitivas.

(2) Flexibilidade: não há uma orientação única. A compreensão pode acontecer tanto num movimento global (top-down) como local (bottom-up). Tudo dependerá da necessidade dos interagentes e do contexto discursivo. Ou seja, a compreensão pode ocorrer tanto do todo para a parte como da parte para o todo.

(3) Interatividade: a compreensão, principalmente aquela realizada em atividades de interação face a face, é negociada, ou seja, é construída de modo colaborativo. Contudo, o mesmo ocorre no caso da leitura de textos escritos (incluem-se também os textos multimodais), pois eles são sempre interativos e possuem marcas com essas orientações.

(4) Inferenciação: a produção de sentido não se dá pela identificação e extração de informações codificadas, mas como uma atividade em que conhecimentos de diversas procedências entram em ação por formas de raciocínio variadas.

Por mais que a atividade de compreensão não precise ser completamente exata e carente de precisão, ela também não pode ser concebida como processo desorganizado e ilógico. Ao contrário disso, ela é uma atividade de seleção, reordenação e reconstrução, em que certa margem de criatividade é permitida. É também uma atividade dialógica que se dá na relação com o outro. (MARCUSCHI, 2008, p.256)

Por não ser uma atividade ilógica, é preciso considerar que podem até existir diferentes compreensões possíveis para um texto, mas há limites que não podem ser 
ultrapassados, ou seja, a compreensão realizada não pode entrar em contradição com a verdade das proposições do texto. (MARCUSCHI, 2008, p.257)

Em concordância com Koch \& Elias (2006, p.21), é necessário reconhecer que $o$ sentido não está apenas no leitor, nem no texto, mas na interação autor-texto-leitor. Portanto, é fundamental que o leitor possa considerar na e para produção de sentido as "sinalizações" (grifos das autoras) do texto, além dos conhecimentos que possui. (Ibid)

Portanto, propõe-se, tendo por base as discussões apresentadas por Vogt (1980, p.7273) e retomadas por Koch (2009c, p.22-23), apresentar as inferências realizadas pelos colaboradores de pesquisa como um contínuo que vai do menor ao maior grau de aproximação da significação textual (sentido 1 e sentido 2), estando relacionados à unidade de estrutura (o que foi dito no texto) ou à unidade de significação (o que não foi dito no texto, mas pode ser inferido). Esse processo pode ser visualizado na Figura 25, que aponta os caminhos percorridos pelo leitor para construção do sentido.

Figura 25. Contínuo da construção dos sentidos.

\begin{tabular}{|c|c|c|}
\hline Sentido 1 & SIGNIFICAÇÃO & Sentido 2 \\
\hline - referencial & I & + referencial \\
\hline - inferencial & | & + inferencial \\
\hline $\begin{array}{l}\text { UNIDADE DE } \\
\text { ESTRUTURA }\end{array}$ & & $\begin{array}{l}\text { DADE DE } \\
\text { IFICAÇĀOO }\end{array}$ \\
\hline DIZER & & $\begin{array}{l}\text { NÃO } \\
\text { DIZER }\end{array}$ \\
\hline
\end{tabular}

Fonte: Autoria própria, baseada em Vogt (1980).

Vogt (1980, p.72-73) afirma que o enunciado diz, quando representa o estado das coisas do mundo; mas que também mostra (sem dizer) a maneira como é representado, por meio das marcas linguísticas e das relações interpessoais. Assim, para esse autor, a construção do sentido possui acepção teatral, pois cada interagente estabelece relações com a unidade de estrutura a ponto de aproximar-se ou distanciar-se da unidade de significação. Logo, é no intervalo entre aquilo que está mais explícito no texto (o dito) e o que dele se pode inferir (o não dito), onde se situam as respostas dos alunos.

\subsubsection{Análise das respostas dos alunos}

A atividade 01 possuía quatro textos a serem lidos pelos alunos, que, na sequência, deveriam produzir textos de pequena extensão. $\mathrm{O}$ ponto de partida foi o seguinte enunciado: 
Leia os textos que seguem e escreva um parágrafo sobre o que compreendeu em cada um deles. Os textos presentes nessa atividade contemplavam temas já apresentados em outras análises realizadas neste trabalho (vide capítulos 1 e 2) nas quais foram inseridos excertos da interação face a face realizada após a aplicação dessa atividade escrita, cujo objetivo era de proporcionar ampliação das inferências realizadas pelos alunos, pois muitos demonstraram dificuldade em atingir a unidade de significação na maioria dos textos dessa atividade.

Foram analisadas, ao todo, 84 produções escritas, que corresponderam à primeira atividade escrita de compreensão textual, composta por 03 charges e 01 tirinha, aplicada para 28 alunos. Os resultados apresentados foram construídos a partir da leitura e da análise das respostas dos alunos, que foram organizadas em grupos (grupo A, B, C...), de acordo com a proximidade de inferências realizadas por eles e inseridas no contínuo, conforme a proximidade ou a distância em relação à unidade de significação. (VOGT, 1980)

No texto 04, mesmo com a ausência de linguagem verbal, existiu uma sequência na imagem que conduzia os leitores a refletirem sobre os problemas relacionados à crise hídrica no Brasil. Todavia, as inferências realizadas pelos alunos poderiam ser expressas num contínuo que se iniciava na apreensão da estrutura textual e ia até a realização de inferências mais relacionadas ao discurso veiculado pela charge.

\section{Texto 04 - Charge}

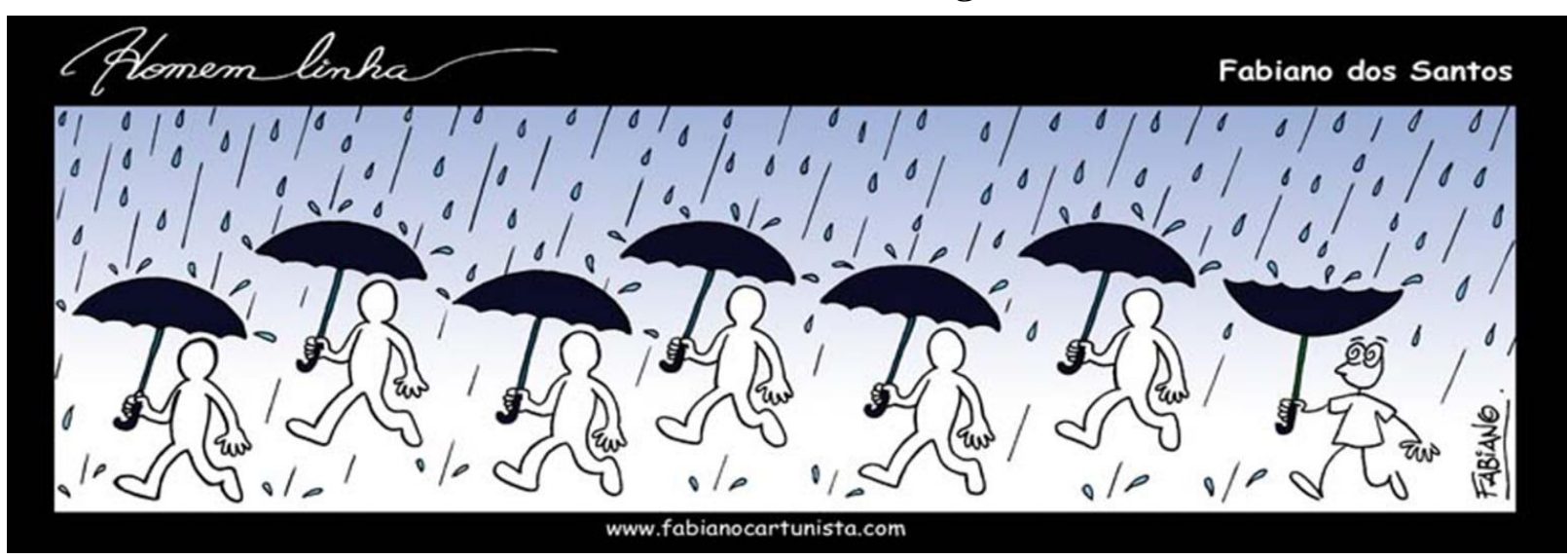

Fonte: https://cantinholiterariososriosdobrasil.files.wordpress.com/2012/08/fabiano-08-2012.jpg. Acesso em $13 / 03 / 2015$

As respostas obtidas são enumeradas a seguir e foram organizadas de acordo com a menor ou a maior aproximação da unidade de significação do texto, sendo reorganizadas no contínuo que ilustra como ocorreu a realização de sentidos (Figura 26). 
Tabela 03 - Síntese das respostas dos alunos (texto 04).

$(\mathrm{A})^{72}$ Os personagens estavam em uma fila quando começou a chover e o último deles teve seu guarda-chuva virado devido a uma grande ventania.

(B) É difícil as pessoas andarem em linha reta por causa da chuva.

(C) O OLHAR DO ÚLTIMO PERSONAGEM INDICA QUE ELE ESTAVA ‘HIPNOTIZADO’ AO VER AS OUTRAS PESSOAS DESPERDIÇANDO ÁGUA ${ }^{73}$.

(D) Chuvas provocadas pelas variações do clima.

(E) Enquanto, em alguns locais, não há chuva, em outros, chove muito a ponto de provocar alagamentos.

(F) Mensagem do autor dessa charge para a importância da reutilização da água da chuva (maioria dos alunos).

Fonte: Autoria própria.

Figura 26. Contínuo da construção dos sentidos (texto 04).

\begin{tabular}{|c|c|c|}
\hline Sentido 1 & SIGNIFICAÇÃO & Sentido 2 \\
\hline - referencial & & + referencial \\
\hline - inferencial & & + inferencial \\
\hline $\begin{array}{l}\text { UNIDADE DE } \\
\text { ESTRUTURA }\end{array}$ & & $\begin{array}{l}\text { UNIDADE DE } \\
\text { SIGNIFICAÇÃO }\end{array}$ \\
\hline DIZER & & $\begin{array}{l}\text { NÃO } \\
\text { DIZER }\end{array}$ \\
\hline
\end{tabular}

Fonte: Autoria própria, baseada em Vogt (1980).

Percebeu-se que os grupos de alunos A e B construíram inferências relacionadas à estrutura imagética do texto, mas que não se referiram à discussão proposta pela charge. Já o aluno $\mathrm{C}$, assim como os grupos $\mathrm{D}$ e E, já relacionaram essa imagem às questões que estavam sendo discutidas em sala de aula acerca da crise hídrica e do aquecimento global. A maioria dos alunos relacionou a imagem (o dito) ao contexto que envolvia a charge (o não dito). Uma das explicações para a realização das inferências pelo último grupo de alunos (grupo F) seria a de que, durante a aula que antecedeu a aplicação dessa atividade, esse assunto havia sido apresentado e debatido entre a professora-pesquisadora e os alunos.

Ao analisar as significações referentes ao texto 03 (Figura 27), percebeu-se que os colaboradores construíram uma diversidade maior de sentidos que se relacionava à imagem,

\footnotetext{
72 A pesquisadora reuniu as respostas por semelhança de inferências realizadas, e o texto que está exposto nas tabelas foi produzido por ela, que procurou parafrasear as respostas fornecidas pelos alunos.

${ }^{73}$ Quando a inferência aparece com fonte em versalete, indica que ela foi realizada apenas por um estudante e não por um grupo de alunos.
} 
ao texto escrito e aos conhecimentos prévios que eles já possuíam a respeito do tema da charge.

\section{Texto 03 - Charge}

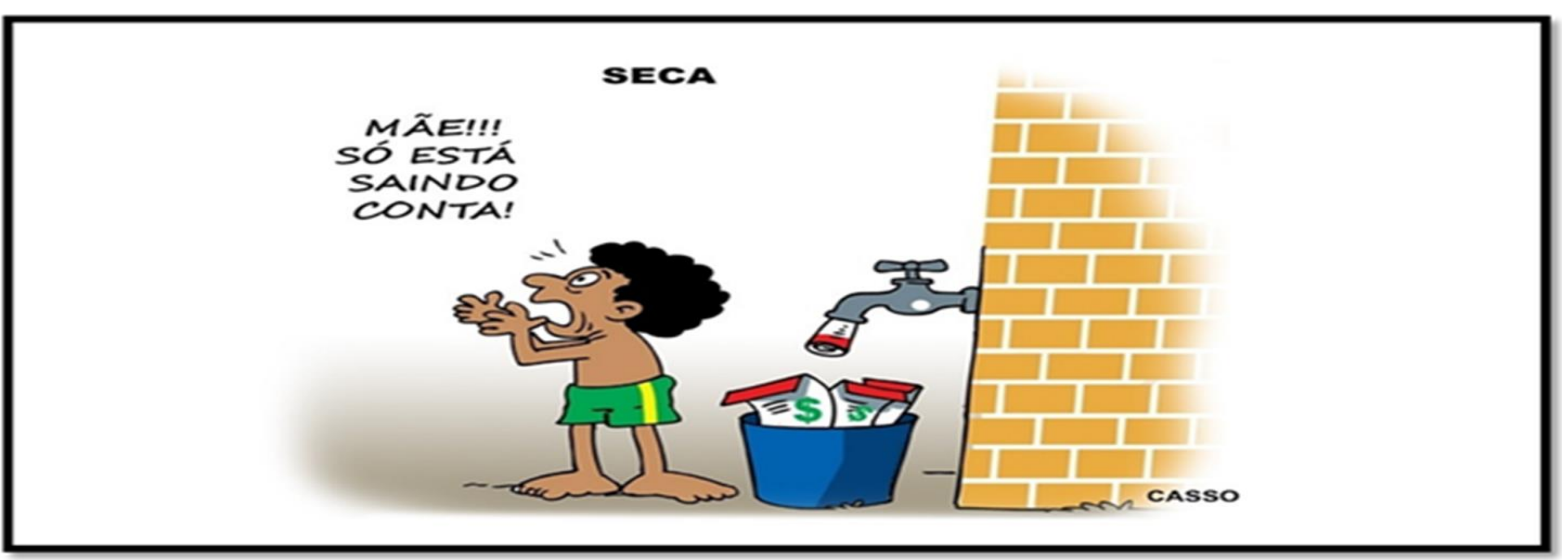

Fonte: http://imguol.com/c/noticias/2014/11/10/11nov2014---o-chargista-casso-ironiza-a-falta-de-agua-queatinge-o-estado-de-sao-paulo-1415645435788_956x500.jpg. Acesso em 13/03/2015

A enumeração das respostas apontou para o equilíbrio entre o sentido 01 e o sentido 02, pois a maioria dos alunos possuía conhecimento prévio a respeito das contas de água que chegavam às casas que não tinham água. Porém, alguns fizeram somente leitura relacionada à superfície textual (imagem e fala do personagem) e poucos (grupos H e I) conseguiram relacionar os dois elementos: os aspectos textuais (unidades de estrutura) e os aspectos contextuais (unidade de significação).

\section{Tabela 04 - Síntese das respostas dos alunos (texto 03).}

(A) CAI DINHEIRO NO BALDE.

(B) O MENINO, COM CALOR, QUERIA TOMAR BANHO.

(C) NÃO TEM MAIS ÁGUA EM CASA E A MÃE PEDE PARA BUSCAR ÁGUA 'DO LADO DE FORA'.

(D) O MENINO ESTÁ COM CARA DE ASSUSTADO POR CAUSA DAS CONTAS/IMPOSTOS QUE NÃO PARAM DE CHEGAR.

(E) Crise econômica: aumento da água, luz, gasolina.

(F) Sai ar da torneira.

(G) Contas altas em Brasília, seca em Brasília.

(H) A CRIANÇA SUJA E DESCALÇA JÁ NOS MOSTRA O QUE VAMOS PASSAR COM A FALTA DE ÁGUA.

(I) Está calor, pois o menino está descalço e sem camisa, mas também há uma crise por falta de água.

Fonte: Autoria própria.

Ficou evidente, ao observarmos as inferências construídas dentro do contínuo (Figura 27), que a compreensão desse texto pelos alunos se relacionou mais aos conhecimentos prévios a respeito do aumento de contas e impostos do que à relação desse fato com a crise 
hídrica que acontecia no país naquele momento. Portanto, nenhum aluno conseguiu, de maneira completa, relacionar os dois elementos do contínuo de significação textual.

Figura 27. Contínuo da construção dos sentidos (texto 03).

\begin{tabular}{|c|c|c|}
\hline Sentido 1 & SIGNIFICAÇÃO & Sentido 2 \\
\hline - referencial & & + referencial \\
\hline - inferencial & & + inferencial \\
\hline $\begin{array}{l}\text { UNIDADE DE } \\
\text { ESTRUTURA }\end{array}$ & & $\begin{array}{l}\text { IDADE DE } \\
\text { VIFICAÇÃO }\end{array}$ \\
\hline DIZER & & $\begin{array}{l}\text { NÃO } \\
\text { DIZER }\end{array}$ \\
\hline
\end{tabular}

Fonte: Autoria própria, baseada em Vogt (1980).

Os alunos A e B não relacionaram o texto ao contexto envolvido. Ao contrário disso, eles apenas decodificaram a imagem, sendo que o estudante A identificou o conteúdo que saía da torneira como dinheiro, e não como contas de água. Tal leitura pode ser explicada por causa do símbolo do cifrão (\$) apresentado na imagem. Já o aluno B apenas fez a leitura da imagem e desconsiderou o conteúdo escrito, bem como o contexto que envolvia a charge, ao inferir que o personagem estava com calor e queria tomar banho.

Os grupos C e D identificaram a unidade de significação, mas estavam mais apegados à unidade de estrutura linguística. A partir da produção escrita feita pelos alunos pertencentes aos grupos E, F e G, já se percebeu a relação entre a unidade de estrutura e a unidade de significação, mesmo que as respostas fornecidas por esses grupos ainda revelassem proximidade à estrutura textual. Por fim, os grupos $\mathrm{H}$ e I foram aqueles que mais realizaram inferências, pois relacionaram a imagem e o texto ao tema que estava sendo discutido no contexto de sala de aula.

O terceiro texto a ser analisado (texto 02) é de autoria de Bill Waterson, criador dos personagens Calvin e Haroldo. 


\section{Texto 02 - Charge}

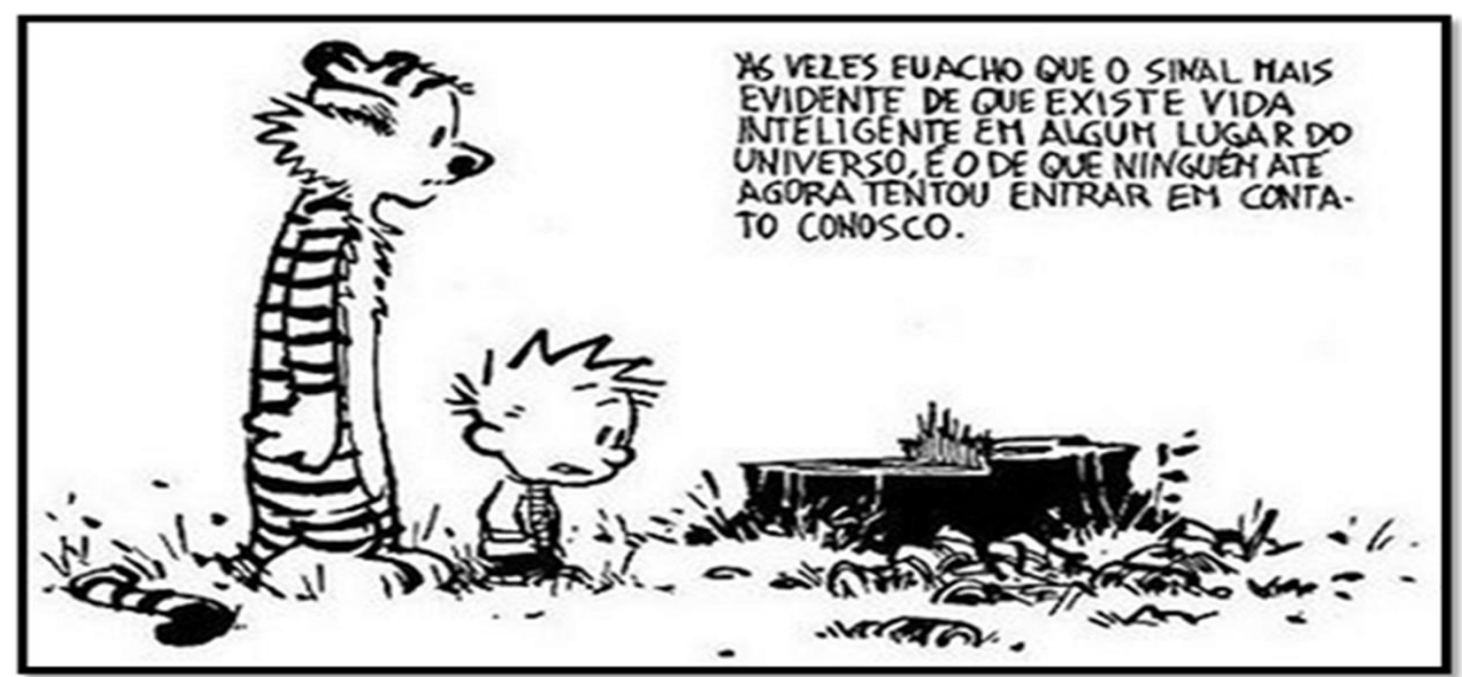

Disponível em: http://sociometricas.zip.net/arch2009-0. Acesso em 13/03/2015.

A maior parte dos alunos não conseguiu relacionar a imagem e a fala do personagem com o contexto que envolvia a imagem. As inferências realizadas pelos estudantes podem ser organizadas da seguinte forma:

Tabela 05 - Síntese das respostas dos alunos (texto 02).

(A) COMO UMA CRIANÇA CONVERSA COM UM TIGRE?

(B) CONVIVER COM A DIVERSIDADE DE COR E DE RAÇA.

(C) NÃO EXISTE VIDA INTELIGENTE EM NOSSO PLANETA.

(D) Cada galho representa um sinal de vida/a raiz é forte/árvore que brota para a vida.

(E) CIGARROS JOGADOS À BEIRA DA ESTRADA.

(F) Os dois personagens estão destruindo a natureza e estão tristes por fazerem a coisa errada.

(G) QUEM ESTÁ PREOCUPADO COM O DESMATAMENTO SÃO AQUELES QUE NÃO PENSAM OU SÃO IRRACIONAIS.

(H) Desmatamento e falta de consciência.

Fonte: Autoria própria.

$\mathrm{O}$ aluno A fez um questionamento a respeito da impossibilidade de uma criança conversar com um tigre. Inferiu-se que o aluno pareceu não conhecer os personagens Calvin e Haroldo e, além disso, ele não se deteve ao texto, que possuía conteúdo linguístico significante para a compreensão da mensagem do autor sobre os danos à natureza causados pelo homem. O estudante $\mathrm{B}$ também produziu uma inferência que não se relacionava à superfície textual e ao contexto de discussão, que estava voltado para a destruição da natureza pelo homem.

Já o aluno C e o grupo de alunos D apegaram-se aos elementos da superfície textual, sendo que $\mathrm{C}$ apenas reproduziu o que estava escrito no texto e o grupo de alunos $\mathrm{D}$ realizou 
somente a leitura da imagem. O aluno E relacionou o texto apenas à destruição da natureza provocada por cigarros jogados na beira das estradas e construiu referência somente contextual, não fazendo menção ao texto sob análise.

$\mathrm{O}$ grupo $\mathrm{F}$ interpretou como se os dois personagens fossem aqueles que destruíram a natureza e se arrependeram por realizarem esse ato. Somente em G e H foram apresentados traços de aproximação da unidade de significação do texto, mas ainda de forma incompleta. Esses resultados indicaram que nenhum aluno, no momento da realização dessa atividade, conseguiu perceber os sentidos da charge de maneira completa.

Assim, o contínuo da construção dos sentidos, no que tange ao texto 02 , pode ser apresentado da seguinte maneira (Figura 28):

Figura 28. Contínuo - construção dos sentidos (texto 02).

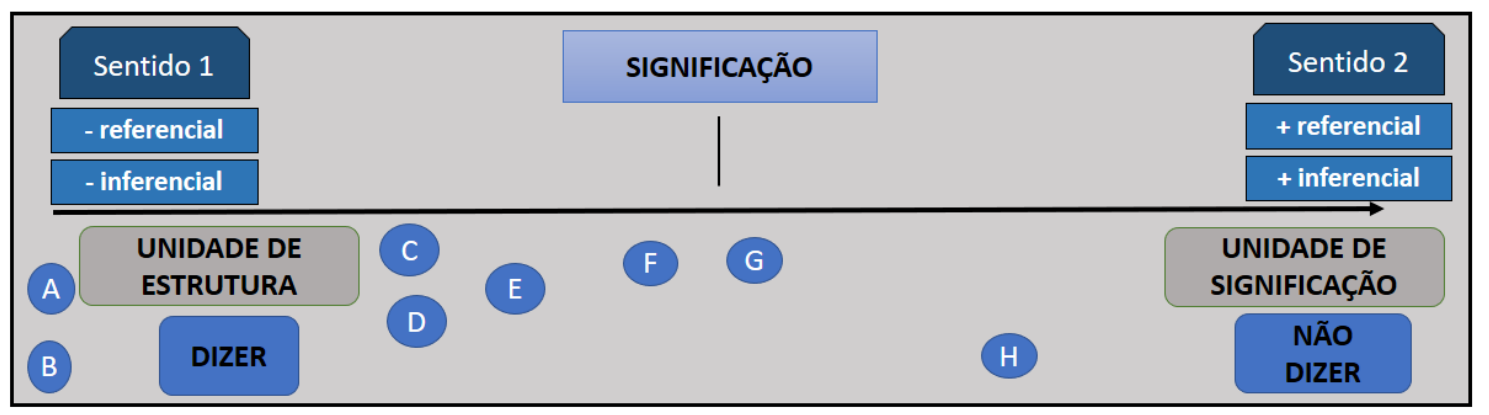

Fonte: Autoria própria, baseada em Vogt (1980).

O texto 05, intitulado de Koisas da Vida, foi o que apresentou inferências mais próximas à unidade de significação do texto. A maioria dos alunos soube relacionar, com sucesso, a unidade de estrutura e a unidade de significação, conforme pode ser visualizado na Tabela 07.

\section{Texto 06 - Tirinha}

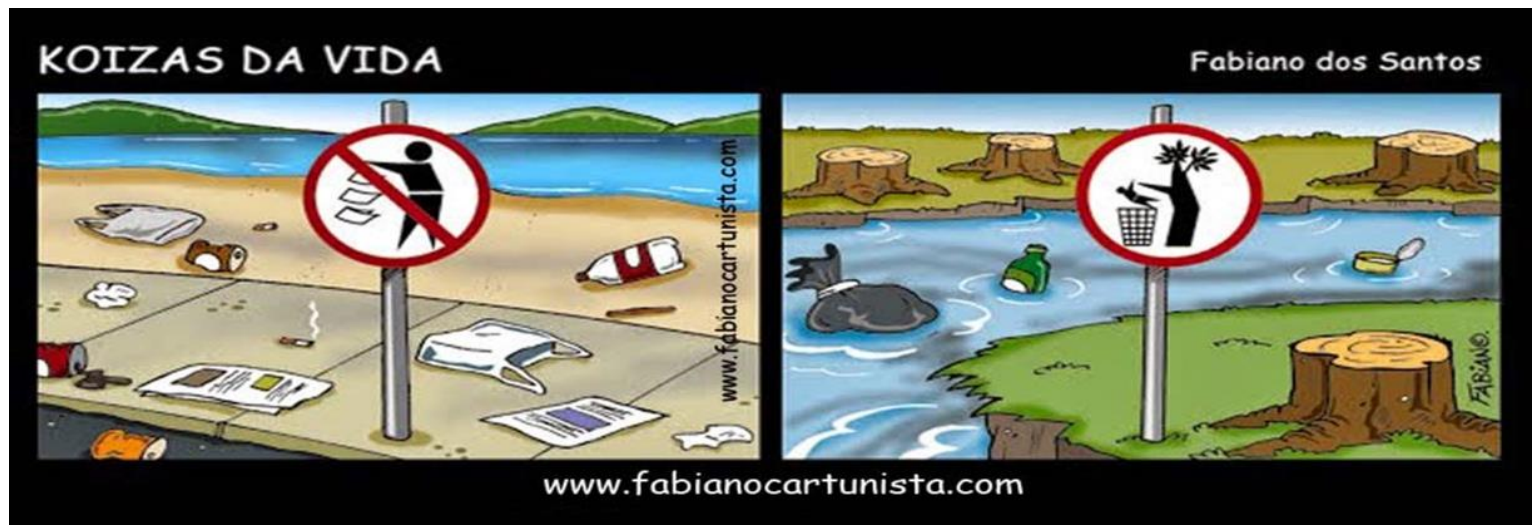

Disponível em: www.fabianocartunista.com. Acesso em 13/03/2015 
Tabela 06 - Síntese das respostas dos alunos (texto 05).

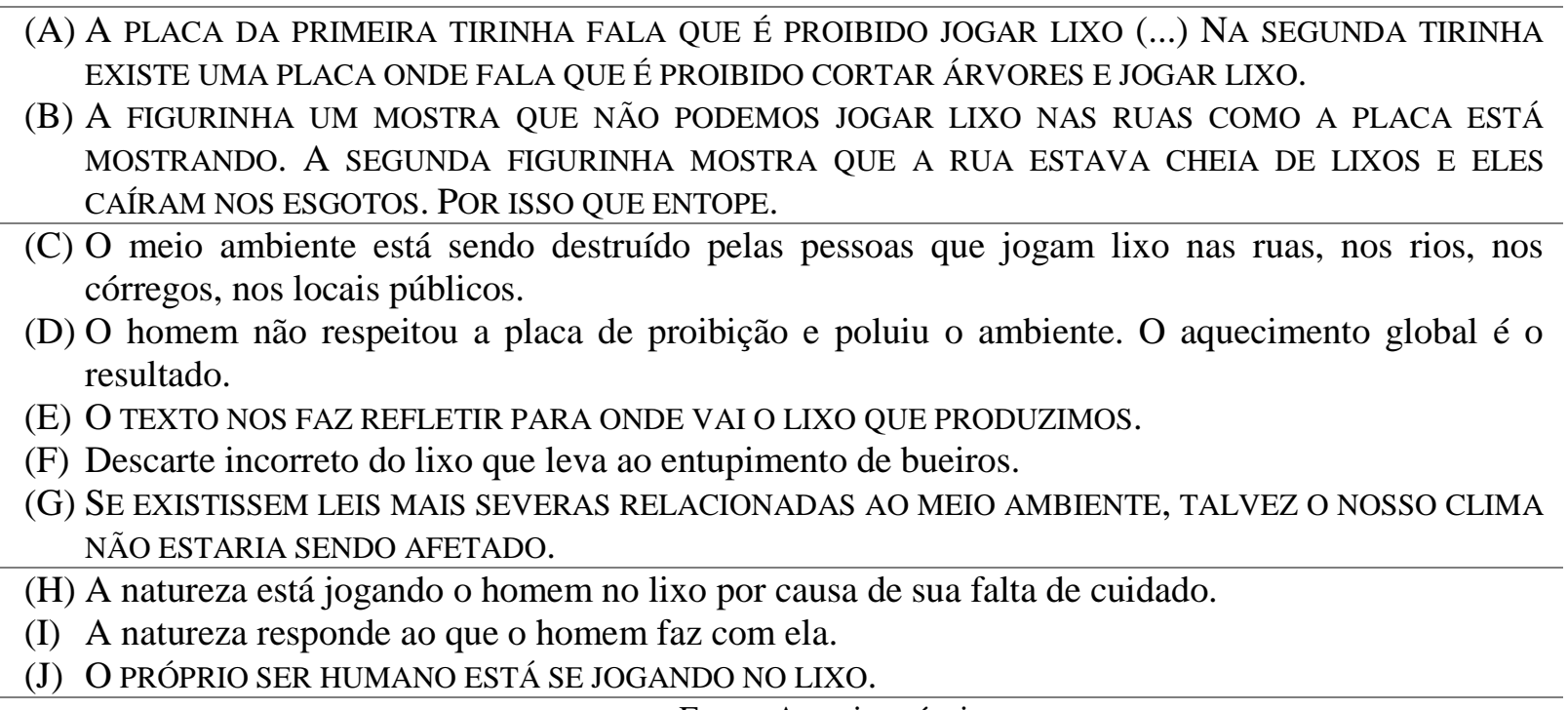
Fonte: Autoria própria.

Os textos das alunas A e B foram os que mais se afastaram da unidade de significação, pois elas se focalizaram a descrição das imagens da seguinte maneira: primeira e segunda tirinha, para a aluna A; e primeira e segunda figurinha, para aluna B - modo como elas se referiram aos quadros que compunham a tirinha. A aluna B viu a imagem como um esgoto que havia sido entupido em função da quantidade de lixo jogado. A aluna A compreendeu que a placa do segundo quadrinho significava proibição de jogar lixo e cortar árvores.

Já o grupo de alunos $\mathrm{C}$ a $\mathrm{G}$, que correspondeu à maioria da turma, conseguiu compreender o teor da tirinha, mas sem estabelecer relação de causa e efeito entre o primeiro e o segundo quadrinhos. Somente os grupos de alunos H, I e J conseguiram estabelecer essa relação, uma vez que detectaram o sentido da segunda placa como consequência do não seguimento das regras pelo homem (vide Figura 29).

Figura 29. Contínuo - construção dos sentidos (texto 05).

\begin{tabular}{|c|c|c|}
\hline Sentido 1 & SIGNIFICAÇÃO & Sentido 2 \\
\hline - referencial & D & + referencial \\
\hline - inferencial & 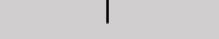 & + inferencial \\
\hline $\begin{array}{l}\text { UNIDADE DE } \\
\text { ESTRUTURA }\end{array}$ & & $\begin{array}{l}\text { UNIDADE DE } \\
\text { SIGNIFICAÇÃO }\end{array}$ \\
\hline DIZER & & $\begin{array}{l}\text { NÃO } \\
\text { DIZER }\end{array}$ \\
\hline
\end{tabular}

Fonte: Autoria própria, baseada em Vogt (1980). 
Portanto, dos quatro textos que compuseram a atividade 01 , o texto 05 foi o que permitiu maior aproximação da unidade de significação, pois a maioria dos alunos conseguiu percorrer o contínuo que vai da unidade de estrutura (superfície textual) à unidade de significação (sentido do texto). Alguns deles também mencionaram o aquecimento global (grupo D) como consequência da irresponsabilidade do homem. Essa constatação pode estar relacionada ao contato que a turma teve com o documentário sobre aquecimento global, exibido previamente pela professora regente da turma.

\subsection{Reflexões sobre o texto como protagonista da aula}

A partir das discussões e dos dados analisados, observa-se que a construção das inferências não constitui processo simples, com resultados exatos. A noção de língua e de texto adotada neste trabalho, bem como o compromisso por uma abordagem qualitativa de análise dos dados, não gera resultados objetivos, uma vez que o olhar da professorapesquisadora se voltou não somente para a unidade de estrutura co-textual, mas focalizou o processo inferencial considerando a relação texto, contexto social e leitores.

Por essa razão, foi necessário resenhar contribuições da Linguística Textual para defender que o texto, neste estudo, é construído sócio-historicamente e só pode ser compreendido dentro de um processo que envolve a ativação de elementos sociais e cognitivos (conhecimentos linguísticos, históricos e culturais). Sob esse aspecto, não se pode desenvolver estudo de texto sem considerar suas múltiplas semioses e seu caráter argumentativo.

Para Vygotsky (1991, p.56), a aprendizagem é resultado do processo iniciado com as experiências sociais, ou seja, as aprendizagens de nível intelectual ou enciclopédico, como também as práticas vivenciadas fora de escola. Nesse sentido, a compreensão textual resulta da ativação de conhecimentos relacionados às experiências sociais somadas às interações estabelecidas em sala de aula com o professor e com os colegas.

Enfim, este capítulo tratou do processo de compreensão textual como atividade que é complexa e interativa, e, por esse motivo, é preciso que o professor tenha sensibilidade para saber quando deve intervir nesse processo, pois as dificuldades que os alunos revelaram, durante a leitura do texto, nomeadas por Kleiman (1989b, p.40) como passividade frente ao texto, não podem ser consideradas como problemas que fogem à responsabilidade da escola. Ao contrário disso, as dificuldades precisam ser detectadas pelo professor, que atuará ora 
como mediador, fornecendo pistas àqueles alunos que não conseguem compreender os aspectos mais implícitos do texto; ora como facilitador (KLEIMAN, 1989b, p.40), fornecendo condições para que o aluno com dificuldades acentuadas possa captar os sentidos do texto e ser capaz de estabelecer interlocução com ele.

Essas práticas de leitura mediada puderam ser vivenciadas pela professorapesquisadora e foram relatadas nas análises dos dados expostas nos capítulos 1,2 e 4 . O próximo e último capítulo discutirá os resultados das atividades de leitura realizadas com a turma que colaborou com esta pesquisa e suas implicações na construção do letramento escolar dos alunos.

No capítulo 5, as dificuldades e as conquistas serão reveladas pelos próprios alunos através dos relatos feitos durante o grupo focal. Assim, por meio dos dados analisados ao longo deste estudo, os resultados e as contribuições teóricas serão sistematizados e discutidos juntamente com os conceitos de Andragogia (educação voltada para adultos) e de letramentos sociais, com o propósito de contextualizar os resultados deste trabalho com a realidade do público adulto que realiza cursos técnicos e que necessita vivenciar atividades de leitura capazes de propiciar a construção de letramento crítico. 


\section{CAPÍTULO 5}

LETRAMENTOS NO ENSINO TÉCNICO: COMPROMISSO A SER ASSUMIDO

O Letramento também significa compreender o sentido, numa determinada situação, de um texto ou qualquer outro produto cultural escrito; por isso, uma prática de letramento escolar poderia implicar um conjunto de atividades visando ao desenvolvimento de estratégias ativas de compreensão da escrita, à ampliação de vocabulário e das informações para aumentar o conhecimento do aluno e sua fluência na leitura. (Ângela Kleiman, 2005, p. 10)

\subsection{Primeiras Palavras}

O propósito deste último capítulo é apresentar e discutir os dados que foram constituídos nos momentos finais do período de geração de dados por meio do grupo focal realizado com estudantes. Nesse momento, eles puderam refletir a respeito da construção de conhecimento, das facilidades e das dificuldades na jornada escolar e nas práticas de leitura e compreensão textual que aconteceram durante os seis encontros nos quais o corpus de pesquisa foi gerado.

No decorrer do capítulo, além dos dados apresentados, também serão discutidos os principais conceitos de letramento que se alinham a este trabalho. Por essa razão, autores como Street (1984, 1993 e 2014), Barton (1994), Kleiman (1995 e 2007), Rojo (2009 e 2012) e Tfouni (2010) irão compor o corpo teórico, por conceberem letramento como prática social e por reconhecerem-no como processo crítico e reflexivo, que precisa ser estudado considerando as relações sociais com a leitura e a escrita estabelecidas diuturnamente pelos estudantes. Outros autores como Freire (1967 e 1989), Morales (1975), Ludojoski (1972), Knowles (2005) e Vogt \& Alves (2005) serão utilizados para a compreensão da Andragogia como área de estudos voltada para compreender como ocorre o processo de aprendizagem do adulto.

Ler, compreender, analisar e produzir gêneros textuais relacionados às práticas sociais dos alunos, além de conhecer outros que não estão relacionados à sua realidade constituem ações que irão promover mudanças na realidade dos estudantes. Essa preocupação faz da aula de Leitura e Produção de Textos um evento de letramento social, escolar, científico e tecnológico, dentre outros letramentos múltiplos apresentados e discutidos por Rojo (2009 e 2012). 
Assim, será apoiado, neste capítulo, o modelo de letramento ideológico (STREET, 2006, p.466), uma vez que é delineado pelas investigações das consequências do letramento na modificação das relações sociais de poder e status. Street (ibid, p.470-471) entende os letramentos como lugares de negociação e de transformação (...) Negociação das posições sociais atribuídas a um grupo de pessoas com identidades marginalizadas e como possibilidade de transformação, por meio das práticas de leitura e escrita que deem condições aos estudantes de agirem como protagonistas no processo de compreensão dos textos, de modo que eles possam ser artífices na transformação de suas próprias realidades.

\subsection{Letramento(s) como prática social}

O termo letramento, recentemente dicionarizado, vem da palavra em língua inglesa literacy, que significa o estado ou condição que assume aquele que aprende a ler e a escrever (SOARES, 2009, p.17). Esse termo foi incorporado aos estudos brasileiros na década de 80 e uma de suas primeiras ocorrências de uso encontra-se em Kato $(1986)^{74}$. Logo depois, em 1987, aparecem nas pesquisas de Tfouni, a distinção entre alfabetização, termo recorrente na língua portuguesa, e letramento, e a incorporação desse item lexical aos estudos da Educação e da Linguística (SOARES, 2009, p.15; TFOUNI, 2010, p.219). Posteriormente, o estudo do letramento como termo voltado às pesquisas linguísticas aplicadas ao ensino da leitura é utilizado por Kleiman (1995). Tfouni (2010, p.218) complementa que os trabalhos de Vygotsky (1991) e Luria (1977 ${ }^{75}$ e 1992) ${ }^{76}$ também já faziam reflexões sobre letramento, sem, contudo, utilizarem esse termo e se aprofundarem sobre os seus significados.

Tanto Kleiman (1995) como Tfouni (2010) compreendem, embasadas nas pesquisas já realizadas na Inglaterra e nos Estados Unidos por Brian Street, que a concepção de letramento precisa abarcar, além das práticas sociais nas quais a leitura e a escrita estão envolvidas, também os significados dessas práticas para os sujeitos, bem como as transformações sociais que elas representam para esses atores sociais.

Essa dimensão social percebe o letramento não como conquista individual do sujeito que aprende a ler e a escrever, mas como prática social que fará parte de sua vivência. Assim, letramento passa a ser compreendido como aquilo

\footnotetext{
${ }^{74}$ Citada por Soares (2009, p.15).

${ }^{75}$ Essa obra foi citada por Tfouni (2010, p.218).

76 Esses estudos foram apresentados no capítulo 02 deste trabalho e dizem respeito à construção social do pensamento por meio das atividades linguísticas.
} 
que as pessoas fazem com as habilidades de leitura e escrita, em um contexto específico, e como essas habilidades se relacionam com as necessidades, valores e práticas sociais; é o conjunto de práticas sociais ligadas à leitura e à escrita em que os indivíduos se envolvem em seu contexto social. (SOARES, 2009, p.72)

A compreensão de letramento como prática social encoraja pesquisas que buscam descrever as diferentes especificidades dos letramentos em lugares e tempos particulares (STREET, 2014, p.18). Os estudos de Street (1984, 1993 e 2014 ${ }^{77}$ ) e Barton (1994) inauguraram os chamados novos estudos do letramento, doravante NEL, pois ampliaram sua noção, que passou a considerar não somente os efeitos cognitivos relacionados à aquisição da escrita, mas também os aspectos antropológicos, históricos e culturais contidos nas práticas sociais nas quais figura a escrita.

Kleiman é uma das principais divulgadoras dos NEL no Brasil. Essa autora (1995, p.18) defende ser o letramento um conjunto de práticas sociais que usam a escrita, como sistema simbólico e como tecnologia, em contextos específicos. Com essa afirmação, fica claro que as práticas de letramento assumidas na escola ou em qualquer outra instituição social serão determinadas pelas condições efetivas da utilização da escrita/leitura numa sociedade.

Mas quais práticas sociais presentes em certa sociedade irão determinar as práticas de letramento vivenciadas na escola? As hegemônicas, de alta valoração social, ou todas as práticas que envolvem a escrita, independentemente de serem valorizadas socialmente? Esses questionamentos irão ser respondidos ao longo desta seção, considerando as concepções de práticas de letramento, eventos de letramento, multiletramentos, letramento autônomo e letramento ideológico, bem como as consequências da escolha de certas práticas no contexto escolar.

Barton (1994, p.34) ${ }^{78}$ ratifica que letramento deve ser entendido como prática social. Esse entendimento envolve a concepção de práticas de letramento e eventos de letramento. Para esse autor (ibid), a concepção de eventos de letramento tem suas origens em Hymes $(1962)^{79}$, na Sociolinguística, com a noção de eventos de fala. Os eventos de letramento são constituídos pelos momentos da vida diária em que a leitura e a escrita se fazem presentes. Para este estudo, interessa investigar os eventos de letramento que ocorreram dentro e fora da

\footnotetext{
77 Trata-se da tradução para o português da obra: Social Literacies: Critical Approaches to literacy in development, etnography and education, publicada pela Editora Longman em 1995.

${ }^{78}$ In: BARTON, D. The Social basis of literacy (capítulo 03). In: Literacy: an introduction to the ecology of the written language. Blackwell Publishers, Oxford, UK,1994. Tradução: Guilherme Veiga Rios.

${ }^{79}$ Citado por Barton (1994, p.36).
} 
escola, pois as inferências realizadas pelos alunos são resultado dos eventos de letramento oferecidos nessa instituição, somados àqueles vivenciados por eles em suas práticas diárias.

Tal resultado pode ser notado no Excerto 23, quando o aluno 12, durante a discussão sobre a influência dos meios de comunicação na conscientização a respeito da falta de água, apresentou seus conhecimentos adquiridos por meio do evento de letramento que vivenciou em seu dia a dia ao assistir ao noticiário vespertino.

\section{Excerto 23 - Aula 01}

01 Aluno 12: Só que trazendo a mídia pra temática, é, eu acho que hoje ela fortaleceria no meio de 02 formar, de educar a sociedade. É assim, o meio mais prático e rápido de educar a sociedade. É 03 assim, o Jornal Hoje, por exemplo... ele falava sobre os acontecimentos no presente, agora, que é 04 a falta de água. E eles disponibilizaram vídeos na qual a população é... faziam em casa e 05 mandavam de meio como prevenir, de como economizar a água. Então, assim, eu vejo nesse

06 momento que ela é muito propício para... pra educar a sociedade.

Por mais que esse evento não estivesse envolvido diretamente com a leitura e a escrita, percebe-se que os textos falados pelos apresentadores dos telejornais foram escritos e passaram pela edição de uma equipe antes de serem lidos por eles. Assim, pode-se dizer que houve contato, mesmo que indireto, com a leitura e a escrita.

Outro exemplo é o da aluna 15, na aula 03, que relatou estar acontecendo em sua casa situação semelhante àquela ilustrada no texto 03 (charge), quando o personagem foi buscar água na torneira e, em vez de água, saíam contas.

\section{Excerto 24 - Aula 03}

01 Aluna 15: Porque mesmo que falta a água, professora, no fim do mês, você vai pagar sempre 02 alguma coisa, mesmo que você vá lá e diga "não, não veio, não tinha a água de jeito nenhum", 03 como aconteceu na minha casa... e mais: a conta chegava com taxas e mais taxas que só eles 04 sabem.

Se a aluna 15 conseguiu estabelecer essa comparação entre a história narrada na charge com a sua realidade, foi porque houve vivência anterior de prática social semelhante. Nesse caso, houve um evento de letramento quando a aluna recebeu a conta de água e conseguiu identificar as peculiaridades desse gênero textual. Por isso, narrou essa situação para a professora-pesquisadora comentando sobre as taxas que vêm sendo cobradas nas contas de água, mas que não eram explicadas pela companhia responsável pela distribuição de água no Distrito Federal. 
Já em relação às práticas de letramento, Barton (1994, p.36) entende que elas dizem respeito aos padrões comuns pelos quais as pessoas utilizam a leitura e a escrita em situações particulares. São as formas culturais gerais de utilização do letramento, com as quais as pessoas se conduzem em um evento de letramento. (Ibid)

Isso significa que as práticas de letramento estão ligadas às atividades culturais que envolvem leitura/escrita comuns a determinado grupo social; elas são construídas dentro de determinado período histórico e de uma cultura específica. Essas práticas são responsáveis pela existência de certos eventos de letramento. Por exemplo, parte do conhecimento que os estudantes já possuíam a respeito da crise hídrica no estado de São Paulo foi construído pela vivência de eventos de letramento, como o contato com esse tema promovido pela professora regente da turma antes da realização das aulas ministradas pela professora-pesquisadora; o contato com contas de água, que os fizeram comparar a situação que eles viviam em São Sebastião - DF com aquela dos moradores de São Paulo (Excerto 24) e o contato com os meios de comunicação social, especialmente a televisão, quando relataram notícias que haviam assistido nos noticiários dos canais abertos de televisão (Excerto 23).

Esses exemplos elucidam as várias agências de letramentos existentes na sociedade: família, igreja, trabalho, mídia, escola, entre outras. Mas é preciso considerar que a escola é, sem dúvida, aquela onde é possível vivenciar quantidade maior de eventos de letramento. Por isso, Rojo (2009, p.107) argumenta ser um dos objetivos primordiais das instituições escolares fornecer a possibilidade de seus alunos participarem de várias práticas sociais que se utilizam da leitura e da escrita (letramentos) na vida da cidade, de maneira ética, crítica e democrática. Essas atividades devem levar em conta os diversos letramentos, ou seja, valorizar os eventos de letramento vivenciados pela comunidade escolar, mas sem deixar de abordar os letramentos valorizados, universais e institucionais. (Ibid)

Do mesmo modo, Kleiman (2007, p. 04) ratifica esse ponto de vista, ao se posicionar que

\footnotetext{
é na escola, agência de letramento por excelência de nossa sociedade, que devem ser criados espaços para experimentar formas de participação nas práticas sociais letradas e, portanto, acredito também na pertinência de assumir o letramento, ou melhor, os múltiplos letramentos da vida social, como o objetivo estruturante do trabalho escolar em todos os ciclos.
}

Rojo (2009, p. 107) chama atenção para os letramentos multisemióticos, os quais envolvem práticas de leitura e escrita de textos contemporâneos, que ampliaram a noção de letramento para o campo da imagem, da música e de outras semioses que não somente a 
escrita. Essa noção foi discutida e exemplificada na seção 4.3 deste trabalho (multimodalidade no processo inferencial).

Novamente Rojo (2012, p.13) argumenta que o conceito de multiletramentos aponta para duas espécies de multiplicidades presentes nas sociedades, principalmente as urbanas: (1) a multiplicidade cultural das populações e (2) a multiplicidade semiótica de constituição dos textos. Isso significa que as práticas de letramento, bem como as pesquisas nessa área, precisam levar em consideração as multissemioses em que as relações sociais são estabelecidas por meio da produção e do consumo de gêneros textuais com recursos semióticos cada vez mais complexos.

Buscam-se, desse modo, letramentos críticos (ROJO, 2012, p.28) que precisam ser objeto de trabalho da escola. O aluno, como consumidor do texto, precisa ser encorajado a ser analista crítico daquilo que lê, seja dentro ou fora dos muros da escola. As reflexões apresentadas neste trabalho, a partir das experiências vivenciadas em sala de aula pela professora-pesquisadora, procuraram investigar os processos envolvidos na compreensão textual, por meio das atividades que compuseram o corpus, a fim de propor eventos de aprendizagem que pudessem gerar letramentos críticos para que os alunos pudessem ter a oportunidade de se tornarem criadores de sentido (...) capazes de transformar (...) os discursos, as significações, seja na recepção ou na produção. (Ibid, p.29)

Os letramentos, portanto, devem ser investigados em seu caráter social, ou seja, em contextos sociais reais (STREET, 2014, p.19) nos quais ocorrem a prática de leitura e de escrita. Além disso, é necessário compreender como os eventos de letramento influenciam a ampliação da leitura de mundo dos estudantes e o modo como eles percebem essas mudanças.

Por isso, a concepção de modelo ideológico será utilizada neste estudo, uma vez que compreende os significados das práticas de leitura e escrita vivenciadas pelos colaboradores de pesquisa dentro e fora do ambiente escolar, ao contrário do modelo autônomo, que se apega tão somente aos resultados estatísticos, aos níveis de elevação social e de encaixamento no mercado de trabalho, despreocupando-se, desse modo, com o processo de aprendizagem da leitura e da escrita e dos significados advindos dessas práticas. Street (2014, p.44) faz essa distinção da seguinte forma:

O modelo (autônomo) pressupõe uma única direção em que o desenvolvimento do letramento pode ser traçado e associa-o a "progresso", "civilização", liberdade individual e mobilidade social. Ele isola o letramento como uma variedade independente e então alega ser capaz de estudar suas consequências. Essas consequências são classicamente representadas como "decolagem" econômica ou em termos de habilidades cognitivas. Um modelo "ideológico", por outro lado, força a pessoa a ficar mais cautelosa com grandes generalizações e pressupostos 
acalentados em torno do letramento "em si mesmo". Aqueles que aderem a este segundo modelo se concentram em práticas sociais específicas de leitura e escrita. Reconhecem a natureza ideológica e, portanto, culturalmente incrustada dessas práticas. (STREET, 2014, p.44)

O modelo ideológico considera que os estudantes precisam reconhecer criticamente os significados do processo de letramento. Além disso, considera que as práticas de letramento ultrapassam os muros escolares e, por isso, há a preocupação de compreender os significados do letramento em diversos grupos sociais (BARTON, 1994 \& STREET, 2014).

Portanto, a concepção de letramento dentro do modelo ideológico se compromete com pesquisas de orientação etnográfica, uma vez que, por meio dessas investigações, pretende-se dar voz às pessoas que vivenciam esses eventos para que seja possível compreender os significados do letramento nas práticas sociais por elas experimentadas. Por essa razão, o grupo focal constituiu estratégia valiosa para compreender como os estudantes perceberam as práticas de leitura durante os seis encontros com a professora-pesquisadora.

\subsection{Letramentos no Ensino Técnico: um olhar para a Andragogia}

Com a finalidade de compreender ainda mais as idiossincrasias dos estudantes que participaram desta pesquisa, é necessária breve contextualização do público atendido pelos cursos técnicos do campus São Sebastião. Não existem dados estatísticos formais divulgados pelo IFB que apontem a faixa etária média, na qual os alunos ingressam nos cursos técnicos subsequentes. Porém, sempre ficou claro para a professora-pesquisadora, a partir de sua experiência como docente da educação básica, técnica e tecnológica, que grande parte dos alunos desses cursos era composta por adultos.

Por essa razão, neste item, será apresentada a Andragogia, área de estudos voltada para a educação de adultos. Até então, a Pedagogia, do grego, paidós, "criança" e agogé, "condução", era a área do saber que compreendia os estudos voltados para o ensino em diferentes âmbitos, mas que privilegiou, durante muitos anos, pesquisas relacionadas à educação de crianças e adolescentes (LUDOJOSKI, 1972). Era necessária, então, a existência de área específica que se dedicasse aos estudos dos processos que envolvem o ensino, a aprendizagem e as políticas públicas voltadas para a educação dos adultos.

Vogt \& Alves (2005, p.207) apresentam o conceito de Andragogia, introduzido, pela primeira vez, por Alexander Kapp, em 1833: 
O termo andragogia foi formulado originalmente por Alexander Kapp, professor alemão, em 1833; caiu em desuso e reapareceu em 1921, no relatório de Rosenstok, sinalizando que a educação de adulto requer professores, métodos e filosofia diferenciados. Eduard Lindeman, em 1927, adotou o termo de Rosenstock e usou-o poucas vezes nos Estados Unidos. O vocábulo andragogia foi utilizado amplamente, desde a década de 60, na França, Yugoslávia e Holanda para se referir à disciplina que estuda o processo da instrução de adulto ou à ciência da educação de adulto. (VOGT \& ALVES, 2005, p.207).

As teorias com foco na educação de adultos foram se desenvolvendo a partir da década de 50, com o trabalho de Malcolm Knowles, intitulado de Informal Adult Education (KNOWLES, 1973), que revela a preocupação desse autor com o modo específico de aprendizagem do sujeito adulto. Para ele (ibid, p.43), quando uma pessoa amadurece, há necessidade e capacidade para auto-direção, para utilizar sua experiência na aprendizagem, para identificar seus próprios modos de aprender, e para organizar a sua aprendizagem em torno de problemas da vida ${ }^{80}$.

Sobre o modo específico de o adulto aprender, Knowles et al. (2005, p. 39-40), inspirados nas ideias de Linderman $(1926)^{81}$, apresentam os principais pressupostos da Andragogia:

1. Os adultos são motivados a aprender quando percebem que suas necessidades e seus interesses estão satisfeitos; portanto, estes são os pontos de partida apropriados para a organização de atividades de aprendizagem de adultos.

2. A orientação de aprendizagem dos adultos é centrada na vida; portanto, as unidades apropriadas para a organização de aprendizagem de adultos são situações da vida, e não assuntos específicos.

3. A experiência é o recurso mais rico para a aprendizagem dos adultos; portanto, a metodologia central da educação de adultos é a análise da experiência.

4. Os adultos têm uma profunda necessidade de se auto-dirigirem; assim, o papel do professor é de se engajar em um processo de investigação mútua com eles, em vez de transmitir o seu conhecimento e, em seguida, avaliá-lo.

5. As diferenças individuais entre as pessoas aumentam com a idade; por isso, a educação de adultos deve prever diferenças de estilo, geração, origem e ritmo de aprendizagem $^{82}$. (KNOWLES et al., 2005, p.39-40)

Durante o processo de interação com os colaboradores de pesquisa, emergiram relatos das experiências de vida de alguns alunos. Isso pode ser exemplificado nos momentos em que alguns deles desenvolveram narrativas referentes às suas experiências de vida com o tema em discussão (vide item 1.5.2, p. 53), tendo esse processo lhes auxiliado na construção de inferências e, por conseguinte, no processo de construção de letramentos.

Ludojoski (1972, p.27) ressalta que Andragogia não pode ser confundida com instrução; relaciona-se, em vez disso, com a educação, uma vez que considera o ser humano

\footnotetext{
80 Tradução própria.

${ }^{81}$ Citado por Knowles (2005, p. 39-40)

82 Tradução própria.
} 
em desenvolvimento, visando ao aperfeiçoamento integral da sua personalidade por meio de sua natureza, cultura e história individual. Esse autor (ibid) afirma que a educação do adulto pode ser considerada em sentido amplo ou em sentido restrito. O sentido amplo se refere à educação de adultos aplicada a qualquer nível que tenha como público pessoas adultas: desde a alfabetização, passando pelo ensino fundamental, até o ensino médio, modalidade que ficou conhecida, no Brasil, como EJA (Educação de Jovens e Adultos).

O sentido restrito se relaciona à complementação das insuficiências pelas quais o adulto passou ao longo de sua vida, podendo compreender cursos profissionalizantes, entre outras complementações educacionais. Tanto o sentido amplo como o restrito são, para Ludojoski (1972), fundamentais para a sociedade, uma vez que a educação voltada para o público adulto o inclui nos processos sociais, tanto na formação básica como nos estudos complementares.

Vogt \& Alves (2005, p.99) contextualizam historicamente que o termo educação de adultos passou a ser tratado no período da Revolução Industrial (séculos XIX e XX), uma vez que, diante do enorme avanço tecnológico da época, que elevou a produção das fábricas e impôs a necessidade de mão de obra operária, houve necessidade, por parte dos empregadores, de formar mão de obra especializada. Houve, então, a ampliação da educação formal, que era somente direcionada às elites, bem como a criação de escolas científicas, técnicas e profissionais, com a preocupação somente de formar técnicos para exercer as funções estabelecidas pelos empregadores.

O percurso histórico da educação de adultos teve práticas não tão condizentes com os pressupostos da Andragogia já apresentados. Vogt \& Alves (2005, p.203) fazem uma crítica ao afirmarem que a educação de adultos, em sua prática, constitui sistema pensado para crianças, mas aplicado para adultos. Ao contrário disso, as pesquisas na área da Andragogia propõem o saber emancipatório, pois os adultos procuram escolas exatamente por perceberem que necessitam construir conhecimentos que ultrapassem aqueles já adquiridos no dia a dia.

No tocante à aproximação teórica da Andragogia com as tendências educacionais dos séculos XIX e XX, a tradição liberal da Escola Nova, que possui visão humanista do ser humano e o considera como ser racional, moral, espiritual e dotado de senso estético, assim como a tendência tecnicista, podem ser consideradas as ideias pedagógicas que mais influenciaram Malcolm Knowles. Assim, essa especificidade da visão humanista de educação concebe que a formação do sujeito acontece, exclusivamente, por meio do desenvolvimento 
pessoal, de modo individualista, e não por meio de um projeto sociopolítico de educação. (Ibid, p.205-206)

Houve, assim, a necessidade de ampliar, nesta pesquisa, a concepção de Andragogia, que muito contribuiu para um novo olhar a respeito do modo de aprender próprio do adulto. Essa necessidade surgiu, porque este trabalho defende que a educação de adultos deve considerar os aspectos humanísticos presentes nos princípios da Andragogia, mas as questões sociopolíticas precisam também compor as bases teóricas dessa disciplina, e isso se realiza por meio de práticas educativas que objetivem o despertar da consciência crítica dos estudantes.

Por essa razão, é preciso discutir as tradições críticas da educação manifestadas, principalmente, nos países da América Latina, a partir da década de 60, tendo Paulo Freire como principal representante. Morales (1975, p.147) entende que Freire ampliou a noção de ser humano, como aquele que possui percepção crítica da realidade, sendo capaz de transformar-se a si mesmo e, consequentemente, o mundo.

\footnotetext{
O mais radical, primeiramente, é que [o homem] seja capaz de ver o mundo como transformável e a si mesmo como sujeito ativo de mudança. A partir daí é que a "percepção crítica” (aspas do autor) da realidade será o pressuposto básico para que o homem possa situar-se no mundo como sujeito livre e consciente que faz a sua própria história, como ser plenamente humano, não estando condenado passivamente a aceitar o mundo feito pelos outros ${ }^{83}$. (MORALES, 1975, p.147)
}

Em resumo, a filosofia presente na obra de Paulo Freire (1967 e 1989) compreende que a educação deve ser capaz de tornar o sujeito mais humano. E ele só será mais humano à medida que for capaz de ser livre para pensar por si mesmo, sendo assim, protagonista de sua própria história (1989, p.155). É nesse ponto que se situa a prática do professor do ensino técnico, que precisa compreender a importância de promover atividades de leitura que suscitem a capacidade criadora do aluno para que, aos poucos, ele seja capaz de realizar atividades de leitura de forma cada vez mais autônoma.

Freire (1989, p.17) alerta para a responsabilidade de os educadores assumirem a ingenuidade dos educandos para poderem, junto a eles, superá-la. Caminhar com os estudantes exige do professor de ensino técnico, e também daqueles de outras modalidades de ensino, humildade para assumir a criticidade dos alunos, aprendendo com eles e superando também sua ingenuidade. (Ibid)

\footnotetext{
83 Tradução própria.
} 
Portanto, é preciso que o professor desenvolva a consciência da necessidade de conhecer o seu público e sua faixa etária, porque a interação com alunos adultos pode conduzir a atividade de leitura para outra perspectiva. É necessário ao professor escutar mais e teorizar menos; facilitar o processo de leitura, em vez de fornecer respostas prontas, que compreendam apenas o seu ponto de vista. É preciso, pois, a introdução de atividades colaborativas e contextualizadas que ampliem as possibilidades de construção de sentido durante a leitura.

\subsection{Relatos do grupo focal: discurso dos alunos a respeito das atividades vivenciadas}

Alguns excertos, provenientes da transcrição do grupo focal, já foram utilizados ao longo deste trabalho em discussões voltadas para as estratégias de construção das inferências e também para justificar o modo coletivo e colaborativo pelo qual o conhecimento é construído nas teorias de sociocognição. Esses excertos compreendem a primeira parte do grupo focal, dedicada à releitura dos textos trabalhados em sala de aula nas atividades coletivas e aqueles utilizados nas atividades escritas de produção compreensiva.

Para esta subseção, o foco será a análise do segundo momento do grupo focal, no qual foram realizadas cinco perguntas aos colaboradores de pesquisa com o objetivo de neles suscitar reflexões sobre as atividades de leitura realizadas nos seis encontros, a fim de perceber, por meio de suas respostas, quais atividades mais contribuíram para a evolução da aprendizagem desses estudantes. As perguntas que conduziram esse segundo momento do grupo focal foram estas:

1. O que vocês aprenderam com os 06 encontros?

2. Como vocês aprenderam o assunto por meio dos textos?

3. Nas atividades realizadas, quais aspectos mais contribuíram para que vocês compreendessem os textos?

4. Quais atividades mais colaboraram para que vocês compreendessem o assunto?

5. O que vocês acham que os professores podem fazer para aprimorar a compreensão textual da turma?

Fairclough (2012, p.95) lembra que os atores sociais, em quaisquer práticas que estejam vivenciando, realizam representações de outras práticas. O autor (ibid) enfatiza que $a$ vida social é reflexiva. Isto é, as pessoas não apenas agem e interagem em redes de práticas 
sociais, elas também interpretam e representam o que fazem para si mesmas e entre si. (Ibid, p.99)

As representações sociais envolvem processos de individualização de ideias e concepções (FERREIRA, 2011, p.28). No caso deste trabalho, referem-se às ideias e às concepções dos alunos acerca das práticas de leitura que eles consideraram mais relevantes. $\mathrm{O}$ grupo focal foi a técnica utilizada pela professora-pesquisadora como estratégia de geração dos dados, com o intuito de suscitar nos estudantes as representações sobre os eventos de letramento vivenciados anteriormente.

Serão apresentadas, a seguir, as principais respostas dos alunos às cinco questões elaboradas, com vistas a evidenciar quais eventos de letramento vivenciados em sala de aula foram considerados mais relevantes para os alunos.

\subsubsection{O que vocês aprenderam com os 06 encontros?}

Com essa pergunta, esperava-se que os participantes pudessem revelar as ações referentes aos encontros conduzidos pela professora-pesquisadora que foram mais relevantes para eles. As respostas obtidas foram organizadas nos excertos 25 e 26.

\section{Excerto 25 - Grupo Focal ${ }^{84}$}

01 Aluna 3: Muita coisa.

02 Aluna 2: Rapaz... Tem que falar mesmo? ((Risos))

03 Professora: E aí?

04 Aluna 2: Vai lá, A1. Você primeiro.

05 Aluno 1: Ah, eu avalio assim uma aprendizagem, é, legal porque abrimos uma discussão, várias

06 discussões vindo de você e dos nossos colegas, porque a partir da colocação dos nossos colegas, a

07 gente pôde também conceituar, né, enriquecer mais o conteúdo. Foi bem discutido, eu gostei.

08 Essa é a conclusão. A minha, né ((riso))

09 Aluna 2: Não, eu gostei. Gostei porque... esclareceu muitas coisas que eu tinha que queria,

10 entendeu? Que não tava claro na minha cabeça com você eu achei, você deu uma clareada muito boa.

11 Professora: Em relação aos textos.

12 Aluna 2: Aos textos e os termos da explicação.

\footnotetext{
${ }^{84}$ A fim de estabelecer uma discussão, em que todos os participantes pudessem ter espaço de fala, foram realizados dois grupos focais. No primeiro grupo, a professora-pesquisadora ouviu os alunos 01,02 e 03 (excertos 25, 27, 29, 31 e 33); no segundo, as participantes foram as alunas 04, 05 e 06 (excertos 26, 28, 30, 32 e $34)$.
} 


\section{Excerto 26 - Grupo Focal}

01 Aluna 4: É:: Eu aprendi muita coisa. Assim, eu gosto de tá estudando sobre a água, sobre o meio

02 ambiente, né. Eu adoro esse estudo, eu aprendi muito sobre isso, né, sobre crise hídrica, né e o

03 meio ambiente, né, em si, eu aprendi bastante.

04 Professora: Na escola?

05 Aluna 4: Hã?

06 Professora: Ah tá. Você aprendeu nas aulas?

07 Aluna 4: Nas aulas que você deu. Aprendi muito sobre isso.

08 Professora: Entendi, aham, ótimo.

$09 \quad$ I../

10 Aluna 5: Pra mim deu uma clareada, porque eu tava meio que tapada nas aulas de português,

11 entendeu. Então, assim, é::, clareou a nossa mente e eu consegui aprender muita coisa. Então, eu

12 gostei muito.

13 Professora: E você?

14 Aluna 6: Professora, eu gostei muito. Assim, eu aprendi mais sobre o meio ambiente. Foi uma 15 coisa que eu sempre ouvi desde criança e quando eu fiz o segundo grau (ali) num colégio (ali).

16 Quando a professora de português entrava e falava: "tira da Mafalda". Eu falava ((risos de A5)).

17 Eu dava um desespero.

18 Professora: E a gente viu uma tira da Mafalda.

19 Aluna 6: Batia um desespero. Esses dias eu tava vendo uma, uma... /..../ Então, hoje, nossa... Eu

20 até comentei com a professora, assim... que eu tava olhando essas charges com, com ( ) verbal e a

21 não verbal pra mim, eu tô tendo mais facilidade.

$22 \quad$ I...I

23 Aluna 6: Desespero porque eu lia, era a mesma coisa de eu tá olhando aqui pra essa coisa em

24 branco ((passa a mão na mesa)). Não saía nada. Não saía nada.

Os participantes do grupo focal revelaram terem aprendido muito com os encontros realizados. No Excerto 25, os estudantes focalizaram mais nos eventos de letramento ocorridos em sala de aula, com a professora-pesquisadora, além de tratarem a respeito da oportunidade que tiveram de compreender o texto por meio das explicações e das interações vivenciadas (linhas 05-08).

Já no Excerto 26, as alunas presentes continuaram relatando as experiências ocorridas em sala de aula, sendo que, nas linhas 14 a 17, a aluna 06 expôs que sempre ouviu falar sobre meio ambiente, ou seja, vivenciou outros eventos de letramento fora da escola que envolviam o tema. Essa mesma aluna relembrou experiências escolares de leitura de textos e descreveu o desespero que sentia ao ver uma tira da personagem Mafalda (linhas 16-24), em razão de sua dificuldade em compreender os aspectos multimodais desse gênero textual.

\subsubsection{Como vocês aprenderam o assunto por meio dos textos?}

Os excertos 27 e 28 apresentam as principais respostas dos alunos sobre como eles construíram conhecimento dentro do tema da crise hídrica, por meio dos textos que compuseram as atividades elaboradas pela professora-pesquisadora. 


\section{Excerto 27 - Grupo Focal}

01 Aluno 1: Foi legal. A gente mostrar uma imagem pra um aluno e fazer ele chegar a uma 02 conclusão. Porque ali surgem ideias diferentes, colocações diferentes quando se retrata uma 03 imagem, uma charge, por exemplo. Porque não tem texto, não tem escrita, então, como a gente, 04 é... tem esse hábito de ler os textos para depois compreender isso às vezes se torna mais fácil pra 05 gente. Mas, a partir de uma imagem, a gente levantar discussões às vezes se torna difícil para o 06 aluno, mas a ideia foi interessante, porque além de olhar e ter as nossas conclusões, nós podemos 07 repassar isso para escrita, entendeu. E é aí onde entra quem não pode, quem não tem o hábito de 08 conversar na turma, de se expressar, melhor dizendo, pôde retratar na escrita, dentro do seu próprio texto.

09 Aluna 3: E trocar ideias, né.

Nesse relato, o aluno 01 se colocou no lugar de analista das práticas desenvolvidas em sala de aula. Isso foi perceptível no uso da terceira pessoa do discurso (linha 01). Logo adiante, na linha 03, ele já se inseriu no discurso, pois começou a avaliar como ele e os demais colegas tiveram que se empenhar para conseguirem compreender textos que possuíam não somente linguagem verbal, mas muitas imagens que exigiam dos alunos mais habilidades para a compreensão do texto. E, segundo esse aluno, eles tiveram a oportunidade de construir suas próprias conclusões, uma vez que realizaram atividades escritas, nas quais tinham que escrever sobre o que haviam compreendido dos textos. Conforme o aluno 01, essas atividades proporcionavam oportunidade não somente para que os alunos extrovertidos participassem do processo, mas também para aqueles mais tímidos, que puderam expressar seus pontos de vista por meio do texto escrito.

Há, nesse relato, o reconhecimento do evento de letramento vivenciado pelo aluno 01 e demais estudantes. Esse aluno percebeu a diferença entre os aspectos verbais e não verbais presentes nos textos lidos e a novidade de o professor apresentar textos com imagens, pois, segundo ele, era mais difícil extrair ideias desses textos em razão da pouca experiência dos alunos com a leitura de gêneros nos quais a multimodalidade era mais evidente.

\section{Excerto 28 - Grupo Focal}

01 Aluna 5: Eu achei muito bom. Me ajudaram, ajudou muito, mas:: se a gente tivesse chance de ter 02 aula até o final do semestre, né?

03 Aluna 6: ENEM que te segure, né! ((risos))

04 Aluna 4: Se a gente tivesse a oportunidade ( ) de ter a sua presença, a gente podia trabalhar mais 05 com produção de texto, né, que é muito bom. Ajuda no concurso, ajuda, até mesmo na faculdade 06 pra quem quer fazer, né.

07 Aluna 5: As redações, aí como ajuda.

08 Aluna 4: Mas deu pra trabalhar bastante, assim, em termo de produção de texto. Aqueles trem lá 09 que você passou. 
As três alunas avaliaram que os textos foram muito bons e que as ajudaram muito, porém, focalizaram suas falas nas atividades em que puderam escrever, relacionando-as a eventos de letramento de alta valorização social, como o ENEM (Exame Nacional do Ensino Médio), avaliação utilizada como forma de ingresso em várias instituições de ensino superior, públicas e privadas, além de citarem os concursos públicos.

Essas estudantes reconheceram o que Street (2006, p.472) chama de letramento dominante, ou seja, o discurso expresso no Excerto 28 evidencia a identificação das alunas com as práticas de letramento vivenciadas na escola e voltadas para a aprovação no ENEM e em concursos públicos. Esses letramentos dominantes relatados pelas alunas representavam, para elas, modos de inclusão social e de inserção no mundo do trabalho, perspectiva que as aproximava de um lugar social por elas almejado. Como analisa Mollica (2007, p.13),

através da escola, acredita-se que o indivíduo se torne agente ativo e transformador; para o cidadão comum, prevalece a ideia de que a educação, especialmente a veiculada na escola e calcada na aprendizagem de ler e escrever, é o caminho mais eficaz de se atingir melhor situação na vida atual.

A escola, portanto, ainda representa local em que os eventos de letramento vivenciados podem ser planejados e aplicados com o intuito de promover inserção nas práticas sociais valorizadas, e as alunas reconheceram essa necessidade a ponto de sugerirem que atividades como aquelas pudessem acontecer com mais frequência durante a vigência do curso que estavam fazendo.

5.3.3. Nas atividades realizadas, quais aspectos mais contribuíram para que vocês compreendessem os textos?

A partir dessa questão, esperou-se que os participantes do grupo focal revelassem quais aspectos relacionados à aplicação das atividades de leitura e compreensão textual mais chamaram a atenção deles e contribuíram para ampliação do entendimento dos textos. Nos excertos 29 e 30, encontram-se as respostas dos estudantes.

\section{Excerto 29 - Grupo Focal}

01 Aluno 1: Eu acho que o recurso slide ele é assim uma forma de melhorar a aprendizagem da 02 gente, porque quando você mostra seu texto, seu conteúdo em slide, é... já dá pra gente entender 03 melhor, até mesmo pela imagem, é, que vem sendo repassada pra gente. Melhor do que você 04 chegar com seu material na apostila, num preto e branco. Você viu aquela imagem que tinha 05 aquele gráfico lá e, embaixo eu acho que era água, né. 
06 Professora: É. Porque tinha a quantidade de água e os anos que se passaram.

07 Aluno 1: ( ) No preto e no branco, já dificulta um pouco, se for no colorido, então, já dá pra gente

08 ter uma noção bem ampla até mesmo nas nossas discussões ou na minha... eu tô falando pra mim.

09 Não pelos colegas. ((ri))

10 Professora: Vocês concordam?

11 ((Alunas 2 e 3 sinalizam que concordam))

12 Aluno 1: O recurso do slide foi muito bom nas suas atividades e não deixa de ser um aspecto também.

\section{Excerto 30 - Grupo Focal}

01 Aluna 4: Eu achei melhor desse jeito que a senhora fez... Foi muito bom. Foi a atividade pra 02 gente, né, e corrigir lá com a senhora, depois volta e corrige com a sala inteira, né. Porque a 03 pessoa fica sabendo no que tá errando, a pessoa já fica atenta. Da próxima vez já vai melhorar 04 naquilo, entendeu? Não sei se a senhora conseguiu (nos acertos), né? Mais aí, é muito bom assim 05 que a gente vai aprendendo.

$06 \quad$ l...l

07 Aluna 6: Tipo, a gente perdeu a timidez, né. Os temas foram atuais, ajudou também a gente 08 desenvolver o texto.

Percebe-se que, no Excerto 29, o aluno 01 se referiu a aspectos relacionados ao recurso didático físico data show, que, segundo ele, facilitou o entendimento do infográfico e de outros textos que possuíam ilustrações coloridas, mas que chegavam até eles em preto e branco nas apostilas fotocopiadas. Os outros colegas não fizeram comentário a respeito, mas ratificaram a informação do aluno 01 , sinalizando que concordavam com ele.

Já as respostas que estão no excerto 30 dizem respeito ao modo como a professorapesquisadora conduziu as atividades escritas, corrigindo individualmente cada análise que os alunos tinham feito e, depois, levando os textos para serem discutidos de forma coletiva. A aluna 04 (linhas 01-05) ressaltou que as atividades de leitura coletiva realizadas pela professora-pesquisadora ofereciam oportunidade para aqueles que não haviam conseguido compreender o texto de modo efetivo, pois os faziam perceber o ponto em que tinham se confundido, fazendo-os ampliar a sua compreensão leitora.

Já a aluna 06 relatou que ela e os colegas perderam a timidez por começarem a desenvolver pequenos textos que expressavam aquilo que eles haviam compreendido nas charges, nas tirinhas e nas reportagens que compuseram as atividades escritas aplicadas.

\subsubsection{Quais atividades mais colaboraram para que vocês compreendessem o assunto?}

\section{Excerto 31 - Grupo Focal}

01 Aluna 3: No fundo do poço. 
02 Professora: No fundo do poço?

03 Aluna 3: Pra mim.

04 Professora: Aquele texto, né "O fundo do poço".

05 Aluna 3: Resumiu, leu e a gente tinha que colocar, fazer um resumo.

06 /.../

07 Aluna 3: A gente tinha que fazer um resumo para dizer o que significa o fundo do poço. Pra

08 mim, no meu ponto de vista.

09 Professora: E vocês A1 e A2?

10 Aluno 1: A atividade que eu mais gostei. Foi aquela que veio três textos pra gente escrever.

11 Professora: Uhum.

12 Aluno 1: A partir da observação da charge. /.../ Eu gostei bastante dela.

Esse primeiro grupo se referiu às atividades que foram aplicadas para que os estudantes as fizessem, primeiramente, de forma individual. A aluna 03 relatou que gostou bastante da atividade de produção textual, que teve como texto norteador a reportagem $O$ fundo do Poço (Anexo II e Apêndice V). Já o aluno 01 revelou ter gostado também da atividade escrita, sendo esta a primeira aplicada para a turma (Apêndice III), que continha charges e tirinhas, com espaços para que eles pudessem escrever sobre aquilo que haviam compreendido no texto.

\section{Excerto 32 - Grupo Focal}

01 Aluna 5: Eu gostei da última, do fundo do poço.

02 Professora: $\mathrm{O}$ fundo do poço.

03 Aluna 5: Gostei sim. Deu pra gente, a gente já tava com a mente mais aberta, né. Então eu, por 04 exemplo, eu consegui desenvolver um texto gigante lá, entendeu. Por causa das explicação e 05 porque a gente já tinha visto antes, né. Então, eu acho que a última foi muito boa.

06 Aluna 6: Eu gostei daquela que tem um rio, um cara pescando e o governo. Que você falou 07 assim, se vocês quiserem refazer o texto e aí eu fiquei conversando comigo mesma ali (com 08 minha filha). Mas se eu for ler, olhar, eu vou fazer a mesma leitura, eu não vou conseguir 09 escrever outra coisa. Minha filha falou: “Ah, é verdade, mãe”. Mas, aí, naquela lá, eu, cara, tinha

10 muita coisa que eu deixei de falar. E, se fosse, eu faria novamente, diferente, ela.

11 Professora: $\mathrm{O}$ da varinha.

12 Aluna 6: $\mathrm{O}$ da varinha.

13 Professora: O governo e o povo.

No segundo grupo, a aluna 05 também identificou a atividade referente ao texto $O$ Fundo do Poço como a que mais colaborou para a compreensão do assunto, pois, segundo ela, a turma estava com a mente mais aberta e, por essa razão, essa estudante conseguiu desenvolver um texto de grande extensão sobre o assunto. A expressão mente aberta indicou que o trabalho prévio com outros textos, que antecederam essa atividade, contribuiu para que o entendimento dessa aluna pudesse ser ampliado. 
A fala dessa mesma aluna também foi relatada no excerto 16 (p. 102), pois, dentre os colaboradores de pesquisa, ela foi a que mais revelou dificuldades para compreender os textos da primeira atividade escrita (vide Figura 17, p. 103), mas relatou, durante o grupo focal, o quanto havia ampliado sua compreensão e sua escrita, em razão de estabelecer contato com vários textos sobre o assunto e de ter, por meio da explicação, ou seja, dos momentos de diálogo entre a professora-pesquisadora e a turma, a oportunidade de ampliar sua compreensão acerca do assunto.

A aluna 06 disse que a charge $O$ povo e o governo (texto 06, p.89) tinha sido a que mais havia gostado. Também relatou que, se tivesse mais tempo para retornar a esse texto, ela poderia ampliar a compreensão. Inclusive, essa aluna revelou ter levado a discussão desse texto para casa, quando narrou parte do diálogo que teve sobre ele com sua filha (linha 09).

As respostas dos alunos que participaram das duas sessões dos grupos focais apontam para a necessidade de uma atividade contínua de leitura de textos seguida de práticas dialogadas com os professores, nas quais esses profissionais atuem como facilitadores por meio da utilização de estratégias, como a do fornecimento de pistas de contextualização que contribuam para que os alunos avancem nos andaimes da compreensão textual.

5.4.5. O que vocês acham que os professores podem fazer para aprimorar a compreensão textual da turma?

A última pergunta feita aos alunos que participaram do grupo focal objetivou compreender seus pontos de vista a respeito das estratégias que podem ser utilizadas pelos professores quando estiverem fazendo atividades de leitura e de compreensão textual. Os excertos 33 e 34 apresentam as respostas desses estudantes.

\section{Excerto 33 - Grupo Focal}

01 Aluno 1: /.../ Então, assim, adaptar algumas pequenas coisas para não seja, quebrar o 02 gel/quebrar esse aluno, entendeu? Para que ele não venha se intimidar e na próxima ele não se 03 sentir nem capaz. Eu acho que dinamizar essa aula, é, com pequenos textos como você, é, 04 atribuiu pra gente, já é um grande avanço pra gente, entendeu, aí foi um grande avanço, porque 05 algumas pessoas nem se expressavam e hoje as pessoas já estão mais assim, participando das 06 aulas até mesmo com os outros professores. Então, a gente tem que falar, é::, não é aquela língua 07 assim cul::ta pra que os alunos ( ), eu sei que é o correto. A gente tem que ensinar o português da 08 forma correta, a gente não quer isso, mesmo quando se leia um texto que ele venha escrito pra 09 você fazer a correção. Então, é inadmissível você pegar e aceitar isso aqui, porque isso aqui está 10 errado, pro aluno, lógico que você vais ter que corrigir, mas é adaptar à realidade dele, entendeu, 11 o que ele vive, dentro de pequenos textos. 


\section{Excerto 34 - Grupo Focal}

01 Aluna 6: Eles tão fazendo, o M ((referindo-se ao professor da disciplina Sociedade e Meio

02 Ambiente)) tá fazendo.

03 Professora: E assim... quais atividades que vocês consideram interessantes, é... pra que a turma 04 possa compreender o texto no momento que lê.

05 Aluna 5: Ah, eu acho que devia, é:: ler com a gente o texto, né. Explicar, aí passar o exercício, 06 corrigir, né, corrige o exercício. Devolve pra gente saber se a gente foi bem, entendeu, no que, é:: 07 pelo menos, na atividade que você passou, eu gostei muito disso. Então, a gente pôde mais ver 08 onde a gente errou, e tal, que a gente pode melhorar, então, não são todos, mas, o M ((referindo09 se ao professor da disciplina Sociedade e Meio Ambiente)), por exemplo, ele passa um filme e a 10 gente tem que fazer um resumo. Só que ele passa dando um visto que vai dando visto de caderno 11 por caderno. Não dá tempo, igual ele falou, quando ele chegou na minha cadeira falou "Ó, eu li 12 por alto, não deu tempo de ver o que você errou". Entendeu, porque não dá tempo de corrigir. 13 Então, se fosse uma folha que pudesse levar e depois devolver, então, eu acho que a gente, é::: 14 melhoraria mais.

15 Aluna 6: Eu também acho assim, o interesse é do aluno, né. Mas eu, assim, pessoalmente, eu 16 acho que você foi muito participativa. Parece que você tava ali e parece que você incentivava a 17 gente, não sei...

18 Aluna 5: Ajudava.

19 Aluna 6: Talvez porque você lia e a gente ficava com aquele interesse e aquilo ali foi ajudando a 20 gente a entender.

No relato do aluno 01 (Excerto 33), ele expressou suas expectativas de os professores terem atitudes que gerassem mais aproximação com seus estudantes, de modo que estes não venham a se intimidar e, consequentemente, se afastarem de seus docentes (linhas 01 e 02). Esse aluno também falou em dinamizar a aula com pequenos textos, fazendo referência à maioria dos textos trabalhados com a turma que pertenciam aos gêneros charge, tirinhas e anúncio publicitário. Ou seja, os textos de curta extensão, segundo esse estudante, colaboraram para que os colegas pudessem se expressar mais por meio da participação nas aulas, inclusive, dos outros professores. Por fim, o aluno 01 defendeu ser preciso ensinar o português da forma correta, mas que, antes disso, era necessário que o professor se adapte à realidade do aluno, aproximando-se dele e da sua realidade para que, depois disso, corrigisseo e avançasse no processo de ensino.

No Excerto 34, a aluna 06 relata que o professor da disciplina Sociedade e Meio Ambiente estava desenvolvendo atividades de leitura e compreensão textual (linhas 01 e 02), e a aluna 05 retomou a ideia da aproximação do professor com o aluno por meio da devolutiva dos trabalhos, a fim de que os estudantes soubessem o que haviam errado para que pudessem, com os erros, evoluir no aprendizado. A aluna 06 ratificou o que a colega havia dito e elogiou 
as aulas da professora-pesquisadora, pois realizava atividades de leitura coletivamente, incentivava os alunos e os auxiliava na compreensão dos textos.

O intuito de realizar essas perguntas, ao final das duas sessões do grupo focal, foi de avaliar as ações realizadas pela professora-pesquisadora e perceber a receptividade dos alunos em relação às atividades de leitura e compreensão textual. As respostas apontaram para práticas de leitura voltadas para a interação entre professores e alunos. Os estudantes revelaram que quando o professor interfere nas atividades realizadas por eles, seja através de correção das atividades escritas, seja proporcionando momentos de discussão coletiva, eles se sentem capazes de progredir no processo de compreensão textual. E o professor tem papel relevante nesse processo de natureza essencialmente cooperativa. (KLEIMAN, 1989b, p.192)

Finalmente, convém retomar o conceito de Zona de Desenvolvimento Proximal - ZDP proposto por Vygotsky (1991). O processo de aprendizagem acontece na ZDP, intervalo entre o desenvolvimento real e o desenvolvimento potencial, ou seja, entre aquilo que o aluno compreende e o que ele ainda não consegue compreender (vide item 2.3, p. 85). E, no contexto escolar, o professor precisa intervir, cuidadosamente, com atividades que privilegiem o desenvolvimento da capacidade de reflexão sobre o texto, as quais envolvam, primeiramente, práticas individuais para familiarização com os sentidos do texto e, depois disso, discussões coletivas que forneçam aos alunos a oportunidade de aprender por meio da interação.

\subsection{Sobre os processos inferenciais revelados: uma proposta didática para atividades de leitura no ensino técnico}

Esta seção irá retomar os processos inferenciais que foram revelados durante a análise dos dados e estabelecer diálogo com as principais dificuldades enfrentadas pelos alunos quando realizaram as atividades escritas de compreensão textual. Além disso, pretende-se retomar, de modo sintético, o percurso dos estudantes entre a primeira (Apêndice III) e a segunda atividade (Apêndice V) escrita, refletindo sobre o que revelaram acerca do processo de ampliação dos objetos de discurso, por meio da escrita e de suas falas durante as aulas, bem como no grupo focal.

Pretende-se, com isso, apresentar proposta didática para os professores dos cursos técnicos e demais profissionais que trabalhem com a educação de adultos, a fim de auxiliá-los na realização de suas aulas. Convém frisar que essas propostas didáticas não constituem 
receitas prontas para qualquer professor utilizar em aulas cuja atividade fim seja a leitura e compreensão de textos. Ao contrário disso, tratam-se apenas de sugestões com base nos resultados desta pesquisa-ação, que se revelaram bastante úteis, uma vez que facilitaram a compreensão textual dos estudantes, os quais ampliaram o entendimento dos textos nos momentos de diálogo entre a professora-pesquisadora e a turma.

Os quatro processos inferenciais revelados foram apresentados, no item 1.5 (p. 50), com embasamento teórico e exemplos fornecidos por meio dos excertos das interações gravadas e das imagens dos textos construídos pelos estudantes. Eles serão retomados, a seguir, com a finalidade de organizar as práticas possíveis de serem assumidas em eventos de letramento que podem ser vivenciados em turmas de cursos técnicos subsequentes (Figura $30)$.

Figura 30 - Esquema dos processos inferenciais revelados.

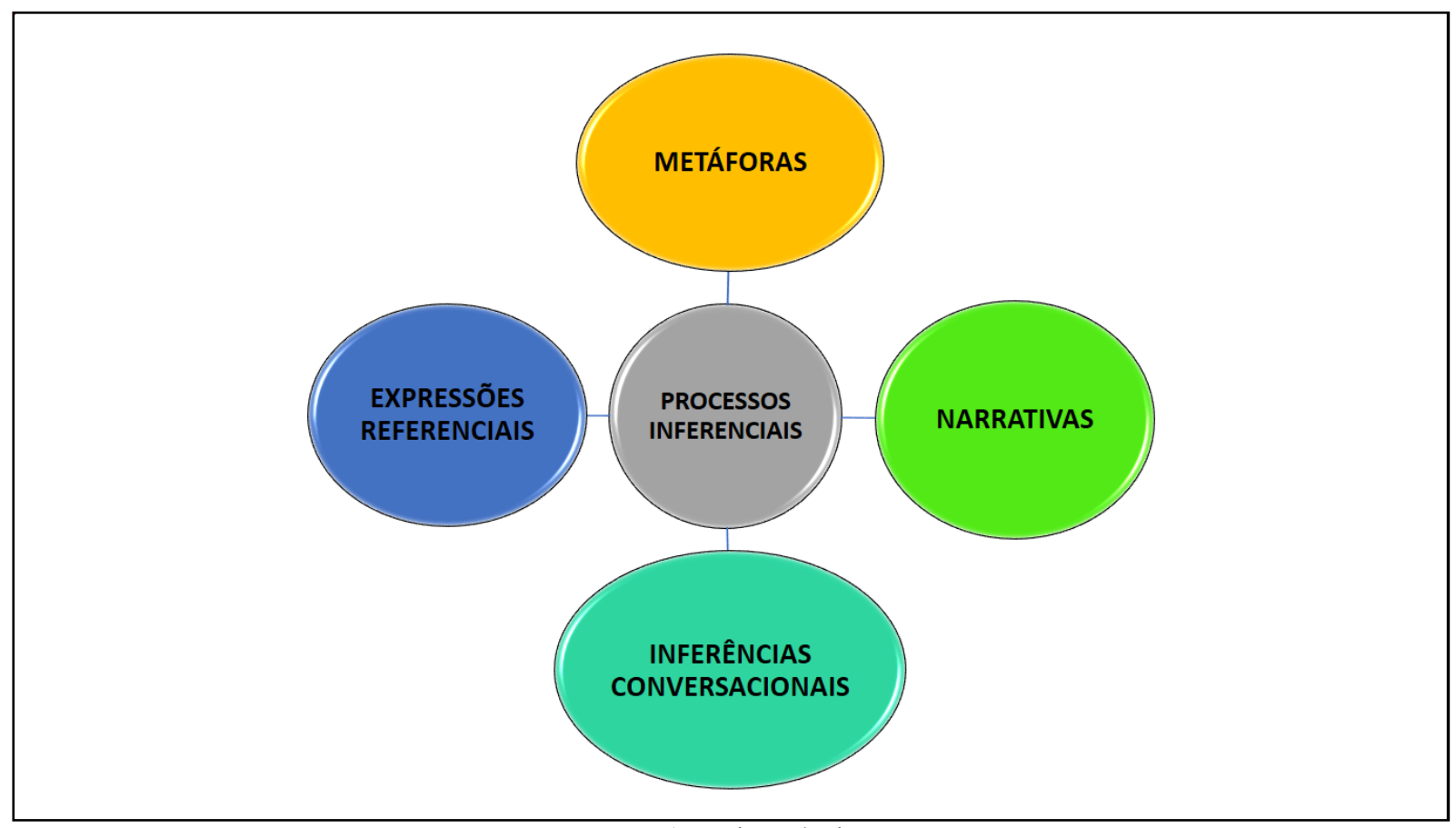

Fonte: Autoria própria.

- Elaboração de Metáforas:

As metáforas conceituais (LAKOFF \& JOHNSON, [1986] 2012) constituem expressões cognitivas construídas a partir de experiências que regem o sistema conceitual dos estudantes. Essas metáforas serviram, no contexto pesquisado, para que os colaboradores de pesquisa avançassem na construção de sentido dos textos. 
Foram observadas metáforas conceituais no texto produzido pela aluna 19 (Figura 06, p. 52), que personificaram o governo e as empresas, que, respectivamente, representavam os agentes governantes e os empresários, atribuindo a eles a responsabilidade de tomar providências em relação à crise hídrica. A metáfora fundo do poço (Anexo II), título do texto que embasou a atividade 02 (Apêndice V), foi incorporada pelos alunos e bastante utilizada em seus textos, como forma de construir argumentação na escritura do texto solicitado nessa atividade. Tomar as dores do planeta também constituiu exemplo de metáfora conceitual que igualmente ajudou na construção da argumentação e na produção de sentidos no texto da aluna 19 (Figura 07, p. 103).

\section{- Elaboração de Narrativas:}

As narrativas são, conforme Bruner (1991 e 2004), modos de organização das experiências e das memórias dos acontecimentos que servem como recurso para a construção de sentido no texto, pois as alunas que desenvolveram narrativas (Excerto 06, p. 54; Excerto 07, p. 56; Figura 08, p. 55) apresentaram histórias que aconteceram em suas vidas como provas empíricas, comprobatórias de seus argumentos sobre as transformações sofridas no meio ambiente em razão da falta de água.

É evidente, desse modo, o caráter sociocognitivo da construção de narrativas, pois elas são transmitidas culturalmente e servem como andaimes metacognitivos para que os alunos, ao narrarem histórias ou situações do dia a dia, possam construir sentido para os textos a partir de suas experiências.

\section{- Elaboração de expressões referenciais:}

A utilização de expressões referenciais já conhecidas pelos alunos e de outras aprendidas nos momentos de interação em sala de aula (KOCH, 2008 e 2014; MONDADA \& DUBOIS, 2003) contribuíram para a compreensão sobre o que estava explícito e implícito nos textos. As leituras e as vivências que alguns estudantes possuíam ajudaram na elaboração das expressões referenciais.

As crenças sociais contribuíram para a construção do conhecimento coletivo. É por meio do diálogo, da cooperação e do comum acordo entre os interagentes que novos objetos de discurso vão sendo construídos. As expressões referenciais, desse modo, foram sendo 
categorizadas e recategorizadas por meio de uma ordem sociocognitiva que ganha sentido nas interações sociais. (MARCUSCHI, 2007a)

Expressões como fundo do poço, popular (para designar a popularidade de São Paulo), contas caras, aquecimento global, mudanças climáticas (figuras 09, 10 e 11, p. 60, 62 e 64, respectivamente), entre outras utilizadas pelos alunos, compuseram o arsenal de léxico utilizado por eles para se referirem aos textos lidos, assim como facilitaram a compreensão dos textos nos momentos de leitura individual e discussões coletivas.

\section{- Inferências conversacionais:}

As inferências conversacionais construídas em atividades dialogadas em sala de aula constituem processo de interpretação vinculado ao contexto (GUMPERZ, 1982a). Os interagentes compartilham sinais indexicais que fazem com que os conhecimentos sejam partilhados para construção/reconstrução coletiva dos objetos de discurso.

Assim, as pistas de contextualização fornecidas pela pesquisadora constituíram gatilhos que propiciaram aos alunos a ampliação da compreensão textual (excertos 10 e 11, p. 68). Tal resultado não seria possível se os textos fossem apenas lidos e interpretados individualmente pelos estudantes. Inclusive, eles sinalizaram, durante o grupo focal, que nos momentos em que foi possível discutir os textos coletivamente, relendo-os e observando-os com mais clareza por meio dos slides coloridos, houve ampliação de entendimento por parte de alguns e, para outros, esses foram momentos em que eles começaram a compreender textos que não faziam sentindo para eles anteriormente.

A análise das respostas que os alunos forneceram para interpretação dos textos da atividade 01 (item 4.4, p. 157) apresentou grande discrepância na compreensão dos textos. Esse dado indicou que, antes da interação com a professora, muitos alunos não possuíam conhecimentos prévios suficientes para interpretarem os sentidos que os textos produziam. Por esse motivo, a realização das inferências conversacionais, que ocorreram em momentos de diálogo entre a professora-pesquisadora e os alunos, deve ser considerada como atividade imprescindível em qualquer aula que considere o texto como objeto de estudo.

É importante ressaltar que o modo como o professor conduz as discussões coletivas é decisivo para o sucesso da aula. Retomando Freire (1989), a prática dialógica em sala de aula é fundamental para que a voz do professor não seja a única a aparecer. Ao contrário disso, a 
voz do docente deve ser aquela que conduz as discussões e aponta para o começo do caminho, que deverá ser trilhado pelos alunos.

\subsection{Reflexões sobre os letramentos no ensino técnico: uma proposta didática}

Este capítulo apresentou as principais teorias de letramento que o concebem como prática social situada, em atividades que envolvem a leitura e a escrita. Em seguida, as práticas de letramento foram contextualizadas à luz da realidade do ensino voltado para o público adulto por meio da discussão sobre Andragogia e de sua relação com as práticas realizadas em turmas de cursos técnicos subsequentes.

O propósito de toda a investigação realizada neste trabalho foi o de desvelar, por meio das práticas realizadas durante a pesquisa-ação participativa crítica, modos de o professor do ensino técnico atuar em aulas que envolvam leitura e compreensão de textos. Os dados analisados e discutidos nos capítulos 01, 02, 04 e 05 foram revelando, aos poucos, atitudes viáveis e que podem gerar resultados produtivos no trabalho de docentes de quaisquer áreas do saber. O esquema (Figura 31), a seguir, expressa as ações que podem ser produtivas para esse tipo de trabalho e para os atores sociais nelas envolvidos.

Figura 31 - Práticas do docente em eventos de letramento no ensino técnico.

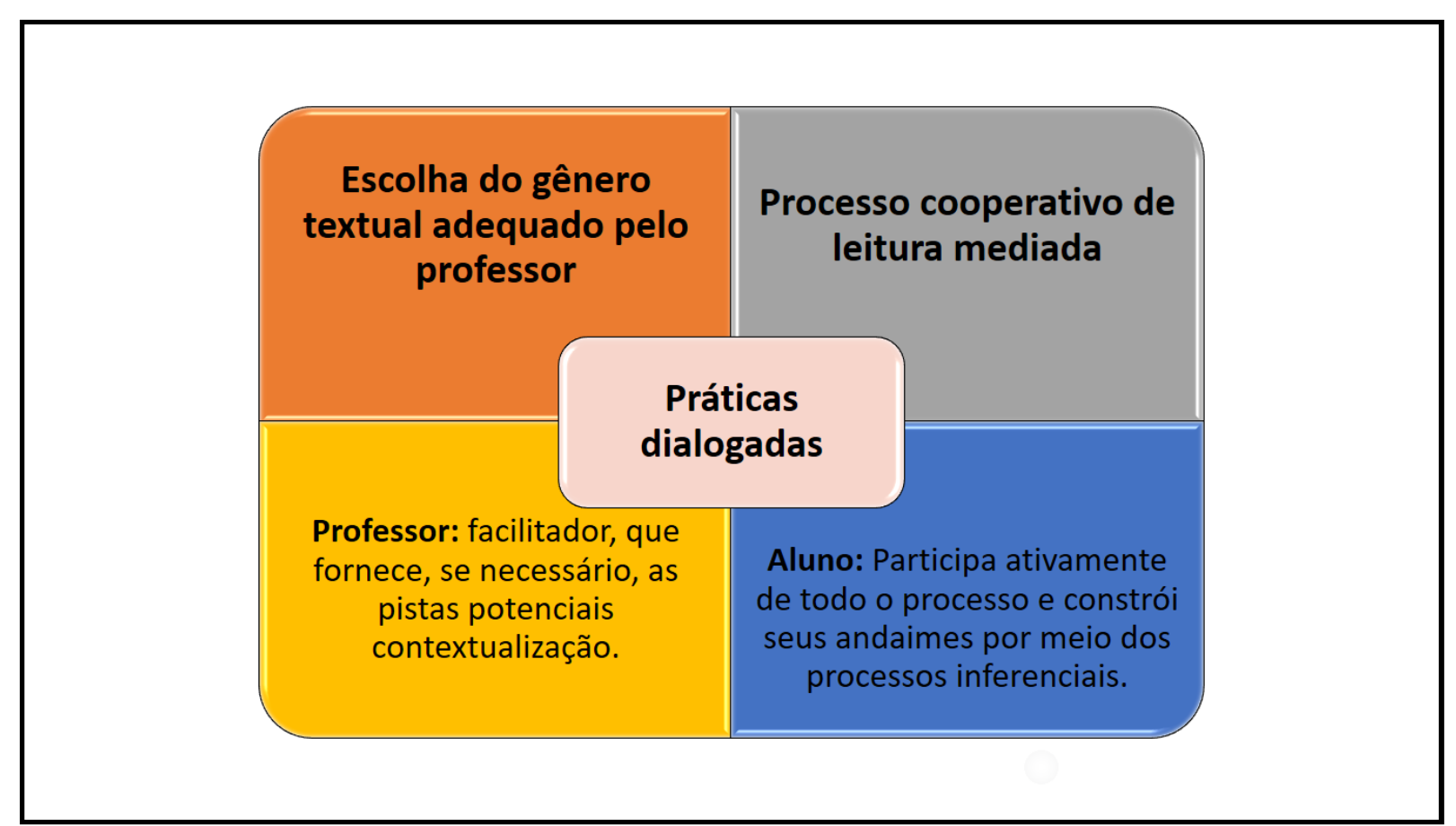

Fonte: Autoria própria. 
A Figura 31 retrata a relação dialógica e cooperativa proposta por este trabalho para atividades de leitura e compreensão textual no ensino técnico. Essa prática dialogada pressupõe que o aluno possa atuar ativamente no processo de compreensão textual por meio da construção de andaimes de forma individual, quando ele realiza atividades individualizadas; ou coletiva, quando participa de práticas dialogadas conduzidas pelo professor, que podem ampliar a compreensão de determinado assunto, seja pela apresentação de outros gêneros textuais, seja pela releitura de textos cuja primeira leitura não tenha sido suficiente para os estudantes realizarem inferências coerentes com o co-texto e o contexto.

Assim sendo, o objetivo primordial de aulas que tenham o texto como objeto central deve ser o alcance da compreensão efetiva dos objetos de discurso pelo maior número de alunos. Para tanto, é necessário que o professor respeite as idiossincrasias de cada um, uma vez que eles possuem ritmos bem diferentes de leitura e compreensão, pois possuem experiências diversificadas com o tema, o vocabulário e as particularidades do gênero textual, que vão exigir, de cada um, habilidades diversas de leitura.

Por essa razão, será proposto, neste trabalho, um encadeamento de ações (Figura 32) que pode servir de referência para a preparação de aulas que envolvam leitura em turmas de cursos técnicos subsequentes, ou que possuam adultos como público principal.

Figura 32 - Proposta didática: encadeamento de ações para o trabalho com a leitura em cursos técnicos.
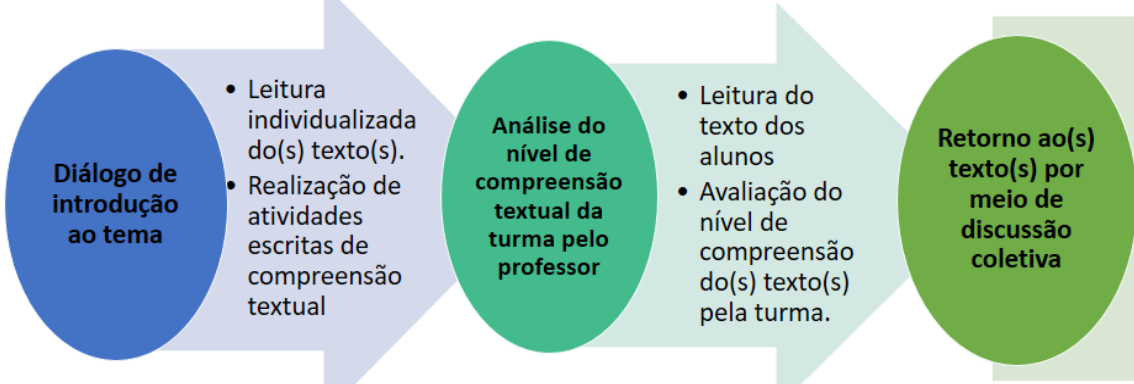

- Professor, como mediador/facilitador da discussão, fornece pistas potenciais quando julgar necessário. - Alunos guiam as discussões e ampliam a compreensão textual por meio do diálogo com professor e colegas. 
Esse encadeamento de ações propõe que, primeiramente, o professor inicie um diálogo com a turma para introduzir o tema a ser discutido. Após essa etapa, o texto será apresentado para que os estudantes realizem atividades escritas individualizadas nas quais demonstrem, por meio de pequenos textos, aquilo que compreenderam do texto objeto de discussão.

Depois da atividade individual, o professor pode realizar a leitura dos textos produzidos pelos alunos a fim de detectar como eles compreenderam os textos e quais as principais lacunas que inviabilizam sua compreensão efetiva. Seria falta de conhecimento sobre o assunto? Houve incompreensão do vocabulário? Os alunos não estão familiarizados com o gênero textual escolhido? Essas e outras perguntas podem ser feitas pelo professor para detectar as principais dificuldades e para procurar saná-las em encontros subsequentes.

A partir dessa análise, o texto será retomado pelo professor e pelos alunos em atividade de releitura coletiva com espaço para diálogo, de modo que o professor atue como mediador/facilitador do processo em momentos nos quais as intervenções dos alunos começarem a fugir dos objetos de significação do texto. Desse modo, o professor lançará pistas potenciais de contextualização para que os estudantes possam realizar as inferências conversacionais e possam, então, descobrir novos objetos de discurso no texto, ampliando, assim, sua compreensão.

Esta proposta didática constitui resultado das experiências vivenciadas pela professora-pesquisadora durante a geração dos dados. Ela não representa proposta fechada, pois foi gerada por meio da vivência de um evento de letramento que sempre representou desafio para professores dos cursos técnicos subsequentes, os quais recorrentemente detectam, no início dos semestres letivos, as dificuldades que os alunos possuem em práticas de leitura e escrita.

Portanto, pretende-se, com esta proposta didática, auxiliar professores e alunos nas atividades de leitura, que não devem ser vistas como atividades simples, a serem realizadas somente em um encontro. É necessário, ao menos, dois ou mais encontros para que a sequência de ações proposta seja realizada com êxito, o que exige, muitas vezes, mudanças de hábitos e opção por um trabalho com um número reduzido de textos, a fim de que a qualidade do trabalho seja priorizada pelos professores e os resultados sejam mais efetivos. 


\section{CONSIDERAÇÕES FINAIS}

Nesta etapa conclusiva, convém relembrar brevemente o caminho teórico e metodológico percorrido e apresentar as contribuições que deste estudo para pesquisas que abordem os processos inferenciais em atividades de leitura.

Este trabalho articulou as teorias da Sociolinguística Interacional com aquelas relacionadas à Sociocognição, à Linguística Textual, e aos estudos do letramento e da Andragogia. Os dados analisados confirmaram as teorias discutidas, uma vez que foi possível observar o viés sociointeracional presente nos processos de compreensão textual realizados pelos alunos nas atividades escritas e nas interações de sala de aula.

Os relatos dos alunos auxiliaram na discussão das representações desses estudantes sobre como as atividades realizadas em sala de aula os ajudaram a compreender os textos, revelando, assim, a importância de o professor elaborar atividades de leitura que permitam a prática dialogal.

Desse modo, tem-se como principais focos desta pesquisa: (1) os quatro processos inferenciais, revelados nas atividades escritas de produção compreensiva realizadas pelos estudantes e nas interações face a face entre a professora-pesquisadora e os alunos; (2) $a$ proposta de trabalho com textos em turmas de ensino técnico, tendo como base central as práticas dialogadas para o ensino da leitura, e (3) a proposta didática do encadeamento de ações para o trabalho com a leitura em cursos técnicos subsequentes, com vistas à ampliação das práticas de letramento vivenciadas pelos estudantes.

Para isso, serão retomadas as perguntas de pesquisa, que se encontram relacionadas aos objetivos específicos a fim de conferir evidência a este estudo.

\section{i. Que processos sociocognitivos são realizados pelos alunos durante o processamento textual em atividades escritas e nas interações com a professora- pesquisadora e com os demais colegas?}

Os processos sociocognitivos revelados foram os chamados pela pesquisadora de processos inferenciais (seções 1.5, p. 50 e 5.4, p. 190), a saber, (1) a metáfora; (2) a narrativa; (3) o uso de expressões referenciais e (4) as inferências conversacionais. Esses 04 processos 
inferenciais foram desvendados em alguns dos textos produzidos pelos alunos e também nas interações face a face, que foram filmadas e estudadas pela pesquisadora. As inferências conversacionais foram reveladas somente nas trocas verbais entre professora-pesquisadora e alunos.

É importante frisar que não foi estabelecido um quantitativo de processos inferenciais a serem inseridos nos resultados deste trabalho. Esta pesquisa possui caráter qualitativo, cujos resultados não precisam ser comprovados por meio de gráficos, tabelas ou outras ferramentas para quantificar informações. Nessa seara metodológica, os dados apresentados buscaram compreender os significados sociais evidenciados por meio das práticas discursivas dos colaboradores de pesquisa.

No caso deste estudo, a pesquisadora identificou traços verbais e alguns não verbais que revelaram os quatro processos sociocognitivos de construção das inferências, ao analisar as respostas dos alunos às questões da atividade 01 (Apêndice III), no texto produzido pelos estudantes na atividade 02 (Apêndice V), assim como nas interações de sala de aula.

Os dados apresentados e discutidos apontaram que a compreensão textual constitui processo inferencial realizado por meio da construção de metáforas e de narrativas, bem como por uso de expressões referenciais e pela realização de inferências conversacionais. Todos esses processos inferenciais são permeados de experiências vivenciadas pelos estudantes no contexto sociocultural em que estão inseridos.

No Excerto 01 (p. 27), por exemplo, a aluna processou a significação da palavra chuveiro de modo diferente da professora-pesquisadora, pois a vivência dessa estudante com esse utensílio doméstico trouxe a ela experiência diferente daquela relatada pela docente. Já no excerto 11 (p. 68-69), nas linhas 22 e 23, outra aluna revelou seu conhecimento a respeito da decomposição dos resíduos sólidos durante a discussão referente ao texto 05 (p. 68).

Do mesmo modo, no excerto 06 (p. 54) e na figura 08 (p.55), a aluna 06 narrou as histórias de fatos vivenciados no rio São Francisco e no córrego de São Sebastião, região administrativa do Distrito Federal, por meio do processo de narração. A aluna 12, no excerto 07 (p. 56), também relatou sua experiência com o desperdício de água de seus patrões na residência em que trabalhava como empregada doméstica.

Assim, em concordância com as teorias estudadas, os dados revelaram que os sentidos são construídos não somente pelo processamento mental do conteúdo linguístico presente no texto, mas pela interação dos aspectos linguísticos com os aspectos socioculturais, uma vez 
que tanto os processos metacognitivos como os sociocognitivos acontecem por meio da junção entre o conteúdo textual e as experiências dos sujeitos durante as atividades de leitura.

\section{ii. Como as pistas verbais e não verbais fornecidas pela professora pesquisadora colaboram para a construção de inferências e atribuição de sentidos ao texto?}

A professora-pesquisadora colocou em prática as teorias relacionadas à sociocognição e às pistas de contextualização durante as práticas de releitura colaborativa dos textos aplicados aos alunos nas atividades escritas, assim como na leitura de novos textos apresentados à turma por meio da exposição de slides.

Desse modo, a pesquisadora procurou conduzir a discussão de forma democrática solicitando que os alunos participassem do processo de atribuição de sentidos aos textos apresentados. No decorrer dessas práticas dialogadas, havia momentos em que os estudantes não conseguiam compreender, por si mesmos, alguns aspectos que a professora-pesquisadora considerava importantes para a compreensão efetiva de determinados textos e, por essa razão, ela fazia, nesses momentos, intervenções orais fornecendo pistas linguísticas potenciais a fim de auxiliar os alunos na construção dos andaimes para compreensão textual. Tal prática pode ser constatada no excerto 02 (p. 31), quando a professora, junto aos alunos, procurou construir um entendimento para a expressão fundo do poço para que eles pudessem iniciar o processo de compreensão antes de realizarem a atividade 02 (produção textual sobre a crise hídrica Apêndice V).

A professora-pesquisadora também forneceu pistas linguísticas potenciais durante a correção da primeira atividade, quando informou os alunos de que Haroldo era um tigre de pelúcia que pertencia ao personagem Calvin (excerto 03, p. 42-43) ou quando construiu com os alunos o sentido da palavra verticalização (excerto 05, p. 48). Também houve fornecimento de pistas nos excertos 12 (p. 89) e 13 (p. 90), quando a professora-pesquisadora apontou para os slides a fim de que os alunos visualizassem detalhes da charge e entendessem os sentidos das palavras governo e povo naquele contexto discursivo (texto 06, p. 89).

Além disso, o excerto 22 (p. 156) também exemplifica momento da aula em que a professora-pesquisadora construiu coletivamente com os alunos os sentidos para o texto 07 (cartaz publicitário da Elektro, que conscientizava a população acerca do desperdício de água, p. 156) por meio do fornecimento de pistas, nos momentos em que houve necessidade de os 
alunos visualizarem certos aspectos do texto importantes para compreensão dos sentidos veiculados pelo cartaz publicitário.

\section{iii. De que forma e por quais elementos a compreensão do texto vai sendo atualizada e reconstruída pelos estudantes ao compartilharem suas inferências em momentos de discussão coletiva?}

Os momentos de discussão coletiva foram importantes tanto para a construção como para a reconstrução dos objetos de discurso do texto. As aulas que aconteceram após a aplicação das atividades escritas representaram momentos importantes nos quais os estudantes puderam rever suas compreensões, contrapô-las com as interpretações dos colegas e perceber os elementos que não foram vistos quando realizaram a primeira etapa da atividade.

O processo de reconstrução de objetos de discurso pôde ser vivenciado na aula 03, quando houve releitura dos 04 textos presentes na atividade 01 (Apêndice III), e a reação positiva dos alunos a atividades como esta pode ser visualizada nos excertos 30 (p. 186), 33 (p. 188) e 34 (p. 189) quando eles revelaram, durante o grupo focal, que reler os textos de maneira coletiva facilitou a compreensão de elementos que eles não tinham identificado sozinhos. Além disso, a exposição de slides, com visualização colorida das imagens constituiu aspecto positivo revelado pelos alunos, uma vez que também facilitou a compreensão das charges, conforme relato do aluno 01 , no excerto 29 (p. 185-186).

Também é preciso retomar a fala desse mesmo aluno quando este revelou (excerto 14, p. 92) ter conseguido compreender o sentido do texto 02 (p. 37 ou p. 166) após um momento de troca verbal com uma colega. Esse resultado indica que os sentidos são construídos não somente por meio das discussões coletivas entre professores e alunos, mas também nas trocas verbais que os discentes estabelecem entre si.

Finalmente, a fala da aluna 05, nos excertos 15 (p. 101) e 16 (p. 102), evidencia a experiência dessa estudante com o processo de compreensão textual em meio às dificuldades que ela revelou possuir durante a realização da atividade 01 (Apêndice III). Porém, essa mesma aluna narrou sua evolução na compreensão do assunto quando usou a expressão nominal mente aberta para mostrar como ela se sentiu mais segura na atividade 02 (Apêndice V), pois já compreendia o tema. Essa experiência conferiu mais segurança a ela no processo de compreensão da reportagem $O$ fundo do poço (Anexo II). 


\section{iv. De que modo a apresentação de diversos gêneros textuais multimodais contribuirá para ampliação da compreensão leitora dos estudantes e para a construção de multiletramentos?}

As teorias apresentadas acerca dos gêneros textuais os consideram como resultados das práticas discursivas estabelecidas pelos sujeitos a partir das suas necessidades, que vão sendo construídas e reconstruídas em meio às transformações históricas e culturais de uma sociedade. Os gêneros textuais são, pois, materializações sócio-históricas e culturais transpostas por meio dos elementos verbais e não verbais presentes nos textos.

Assim, os resultados desta pesquisa sugerem que o trabalho do professor com atividades de leitura em cursos técnicos subsequentes, cujo público é formado, em sua maioria, por adultos que já possuem experiências escolares anteriores positivas e/ou negativas com atividades de leitura e compreensão de textos, precisa ser permeado de textos coerentes com temas a serem trabalhados com a turma. Além disso, é importante que o docente explicite para os estudantes os objetivos e as características desses gêneros textuais como primeiro passo para que eles compreendam o papel social do texto em suas vidas.

No contexto deste trabalho, a professora-pesquisadora elencou, em parceria com os alunos, as principais características do gênero textual charge, pois vários dos textos selecionados para as aulas pertenciam a esse gênero discursivo (excertos 17, p. 147 e 18, p. 148). Essa foi uma das escolhas da pesquisadora, pois pretendia investigar o processo de construção das inferências em textos nos quais as linguagens verbal e não verbal pudessem interagir entre si.

A mesma escolha da pesquisadora se deu quando selecionou o boletim informativo, texto oral que foi escutado pelos alunos (excerto 19, p. 149); o infográfico (excerto 20, p. 153), que foi analisado coletivamente quando a professora-pesquisadora projetou o site no qual esse gênero se encontrava, além do anúncio publicitário (excerto 22, p. 156), cujos aspectos imagéticos desse texto foram apontados pela docente e analisados coletivamente. Durante as discussões coletivas, a professora-pesquisadora procurou sempre evidenciar os aspectos multimodais que influenciaram na construção de sentido para esses textos. 


\section{v. Que atividades didático-pedagógicas poderiam ser realizadas para desenvolver competência de processamento textual tendo em vista a ampliação das inferências realizadas pelos alunos?}

Este estudo aponta não somente para uma atividade didático-pedagógica específica que pudesse desenvolver a competência leitora dos estudantes. $\mathrm{Na}$ verdade, os resultados indicam a necessidade da promoção de atividades de leitura que priorizem práticas dialogadas entre professores e alunos. De tal modo, propõe-se o encadeamento de ações para o trabalho com a leitura (Figura 32, p. 197), aliado às práticas que os docentes podem realizar em eventos de letramento no ensino técnico (Figura 31, p. 196).

Por meio dessa proposta didático-pedagógica, espera-se que os estudantes tenham oportunidade de vivenciar processos metacognitivos e, que após esse primeiro contato com $\mathrm{o}(\mathrm{s})$ texto(s), possam compartilhar com os colegas e os professores suas indagações e suas experiências, ampliando sua compreensão por meio da realização de inferências conversacionais e do processamento das pistas de contextualização a serem fornecidas pelos professores sempre que julgarem necessário auxiliar o(s) aluno(s) no processo compreensivo.

Portanto, este trabalho procurou contribuir para o repensar das práticas de leitura realizadas por professores de diferentes áreas do saber em cursos técnicos subsequentes. Além disso, apontou os processos inferenciais revelados no contexto estudado, uma vez que se trata de uma pesquisa situada. Espera-se, assim, que trabalhos futuros possam evidenciar outros processos nos quais as inferências são construídas para, deste modo, ampliar ainda mais o campo de estudos relacionados à compreensão leitora em perspectivas sociointeracionais e sociocognitivas. 
ADAM, J. M. Los textos: tipos y protótipos. Relato, discripción, argumentación, explicación, diálogo. Paris: Natan, 1992.

ANGROSINO, M. Etnografia e observação participante. Porto Alegre: Artmed, 2009.

Állan, S \& SOUSA, C. B. A. O Modelo de Tomasello sobre a Evolução CognitivoLinguística Humana. In: Psicologia: Teoria e Pesquisa, Vol. 25 n. 2, pp. 161-168, Abr-Jun 2009.

AUSTIN, J. L. How to Do Things with Words. Oxford: Clarendon Press, 1962

Quando dizer é fazer. - Trad. Danilo Marcondes de Souza Filho. Porto Alegre: Editora: Artes Médica, 1990.

AZEVEDO J. L. História de António Vieira. Lisboa: Livraria Clássica Editora, 1931.

BAKHTIN, M. Estética da Criação Verbal. São Paulo: Martins Fontes, [1979] 1997.

Marxismo e Filosofia da linguagem. 14 ed. São Paulo: Hucitec Editora, 2009.

BARBIER, R. A pesquisa-ação. Brasília: Liber Livro, 2007.

BARBOUR, R. Grupos Focais. Coleção Pesquisa Qualitativa. Porto Alegre: Artmed, 2009.

BARTON, D. Literacy: an introduction to the ecology of written language. Oxford, UK: Blackwell Publishers, 1994.

BATESON, G. A. Uma teoria sobre brincadeira e fantasia. In: RIBEIRO, B \& GARCEZ, P (orgs.). Sociolinguística Interacional. São Paulo: Loyola, 2002. Tradução Lúcia Quental.

BAZERMAN, C. Gêneros textuais, tipificação e interação. São Paulo: Cortez, 2005.

Gêneros, Agência e Escrita. HOFFNAGEL, Judith C. DIONÍSIO, Ângela P.(org.) São Paulo: Cortez, 2007.

BEAUGRANDE, R. de New Foundations for a Science of Text and Discourse: Cognition, Communication, and Freedom of Access to Knowledge and Society. Norwood, New Jersey: Alex, 1997.

\& DRESSLER, W.U. Introduction to Text Linguistics. New York, Longman, 1981.

BENTES, A. C. Linguística Textual. In: MUSSALIM, F \& BENTES, A. C. Introdução à Linguística: domínios e fronteiras. São Paulo: 2012. Volume 01.

BENVENISTE, E. Problemas de Linguística Geral II. Campinas, SP: Pontes Editores, [1974] 2006. 
BEZEMER, J \& JEWITT, C. Multimodal Analysis: Key issues. In: Litsseliti. L (ed.). Research Metthods in Linguistics. London: Continuum, 2010. pp 180-197.

BLOMMAERT, J. Contexto é/como crítica. In: SIGNORINI, I. Situar a linguagem. São Paulo: Parábola Editorial, 2008. pp. 91-115.

BONINI, A. Gêneros textuais e Cognição. Florianópolis: Insular, 2002.

A relação entre prática social e gênero textual: questão de pesquisa e ensino. In: VEREDAS ON LINE - ENSINO - 2/2007, pp. 58-77.

BORTONI-RICARDO, S. M. \& SOUSA. M. A. F. Andaimes e pistas de contextualização: um estudo do processo interacional em uma sala de alfabetização, 2003. Disponível em: http://www.stellabortoni.com.br/docs/f96BORTONIandaimes.doc. Acesso em 21/09/2009.

Parábola, 2008.

- O professor pesquisador: introdução à pesquisa qualitativa. São Paulo:

BRASIL, Presidência da República. Lei no 11.892 de 29 de dezembro de 2008. Institui a Rede Federal de Educação Profissional, Científica e Tecnológica, cria os Institutos Federais de Educação, Ciência e Tecnologia, e dá outras providências. Brasília, DF, 2008. Disponível em: https://www.planalto.gov.br/ccivil_03/_ato2007-2010/2008/lei/111892.htm. Acesso em: 11/12/2013.

Ministério da Educação. Conselho Nacional de Educação. Câmara de Educação Básica. Resolução $\mathbf{n}^{\mathbf{0}}$ 6, de 20 de setembro de 2012. Define Diretrizes Curriculares Nacionais para a Educação Profissional Técnica de Nível Médio. Disponível em: http://mobile.cnte.org.br:8080/legislacao-externo/rest/lei/51/pdf, acesso em 02/09/2016.

BRONCKART, J.P. Atividade de linguagem, textos e discursos: por um interacionismo sociodiscursivo. São Paulo: Educ, 2009. Trad. Anna Rachel Machado.

BROWN, P. \& FRASER, C. Speech as a marker of situation. In: K. R. Scherer and H. Giles (eds.), Social markers in speech. Cambridge: Cambridge University Press, 1979.

BRUNER, J. Child's Talk: learning to use language. New York: Norton, 1983.

Actual Minds, possible worlds. Cambridge: Cambridge University Press, 1986.

A construção narrativa da realidade. In: Critical Inquiry, 18(1), 1991. pp. 1-21. trad. Waldemar Ferreira Netto.

Realidade mental, mundos possíveis. 2. ed. Porto Alegre: Artes Médica, 2002.

Life as a narrative. In: social research Vol 71 : No 3, 2004. pp. 691-710.

CARR, W \& KEMMIS, S. Becoming Critical: education, knowledge and action research. New York: Routledge Farmer, Taylor and Francis Inc, 1986-2004.

CAVALCANTE, M.M. \& CUSTÓDIO FILHO, V. Revisitando o estatuto do texto. In: Revista do GELNE, Piauí, v.12, n.2, 2010. pp. 56-71. 
Os sentidos do Texto. São Paulo: Contexto, 2012.

\& SANTOS, L. W. dos. Referenciação e marcas de conhecimento partilhado. In:

Linguagem em (Dis)curso, Tubarão, SC, v. 12, n. 3, p. 657-681, set./dez. 2012.

; CUSTÓDIO FILHO, V \& BRITO, M. A. P. Coerência, Referenciação e Ensino.

São Paulo: Cortez, 2015.

CLARK, H. H. Using Language. New York, Cambridge University Press, 1996.

COHEN, L; MANION, L \& MORINSON, K. Research methods in education. London \& New York: Routledge, 2007.

COOK, Anne E.; LIMBER, John E.; O'BRIEN, Edward J. Situation-Based Context and the Availability of Predictive Inferences. Journal of Memory and Language 44, 220-234, 2001.

CORTEZ, S. L \& KOCH, I. G. V. A construção do ponto de vista por meio por meio de formas referenciais. In: CAVALCANTE, M. M \& LIMA, S. M. C. (orgs.). Referenciação: teoria e prática. São Paulo, Cortez, 2013.

COSCARELLI, C. V. Reflexões sobre as inferências. Anais do VI CBLA - Congresso Brasileiro de Linguística Aplicada, Faculdade de Letras da UFMG, CD Rom, 2002.

DEMO, P. Metodologia científica em ciências sociais. São Paulo: Atlas, 1995. 3 ed.

EERDMANS, S. L; PREVIGNANO, C. L. \& THIBAULT, P. J. Language and Interaction. Discussions with John Gumperz. Amsterdam: John Benjamins, 2003. p.p. 06-23.

ESTEBAN, M. P. S. Pesquisa qualitativa em Educação: fundamentos e tradições. Porto Alegre: Artmed, 2010.

FAIRCLOUGH, N. A dialética do discurso. In: MAGALHÃES, I. (Org.). Discursos e práticas de letramento: pesquisa etnográfica e formação de professores. São Paulo: Mercado de Letras, 2012. pp. 93-107.

FÁVERO, L. L \& KOCH, I. G.V. Linguística Textual: introdução. São Paulo: Cortez, 2008.

FAUCONNIER, G. Mental Species. Cambridge: Cambridge University Press, 1994.

\& TURNER, M. The way we think: conceptual blending and the mind's hidden complexities. New York: Basic Books, 2002.

\& TURNER, M. Rethinking Metaphor. In: Gibbs, R. (ed.) Cambridge Handbook of Metaphor and Thought. Cambridge: Cambridge University Press, 2008.

FERRARI, L. Introdução à Linguística Cognitiva. São Paulo: Contexto, 2011.

FERRAZ, J. A. A Multimodalidade no ensino de Português como segunda língua: novas perspectivas discursivas críticas. Brasília. Tese (doutorado em Linguística). Universidade de Brasília, 2011. 
FERREIRA, A. S. O discurso de professores do ensino superior: estilos e identidades. Dissertação (Mestrado em Linguística). Universidade de Brasília, 2011.

FILLMORE. C. Frame semantics and the nature of language. In: HARNAD, S. R., STEKLIS, H. D., \& LANCASTER, Jane. Origins and Evolution of Language and Speech, Annals of the NY Academy of Sciences, Vol. 280, 1976. pp. 20-32.

Frame semantics. In: Linguistics in the Morning Calm, ed. by the Linguistic Society of Korea, 111-137. Soeul: Hanshin, 1982.

FRAWLEY, W. Vygotsky e a ciência cognitiva. Porto Alegre: Artmed, 2000.

FREIRE, P. Educação como prática de liberdade. Rio de Janeiro: Paz e Terra, 1967.

Conscientização: teoria e prática da libertação: uma introdução ao pensamento de Paulo Freire. São Paulo: Cortez \& Moraes, 1979.

A importância do ato de ler. São Paulo: Cortez, 1989.

FRIEDRICH, J. Lev Vigotski: Mediação, Aprendizagem e Desenvolvimento. Uma leitura Epistemológica. São Paulo: Mercado de Letras, 2012.

GOFFMAN, E. A Situação Negligenciada. Trad. Pedro M. Garcez. In: RIBEIRO, B \& GARCEZ, P (orgs.). Sociolinguística Interacional. São Paulo: Loyola, [1964] 2002.

A Representação do Eu na Vida Cotidiana. 17 ed. Petrópolis, Vozes, 2009.

GONDIM, S. M. G. Grupos Focais como Técnica de Investigação Qualitativa: desafios metodológicos. In: Paidéia, 2003,12(24), 149-161.

GOPNIK, A. How we know our minds: The illusion of first-person knowledge of intentionality. Behavioral and Brain Sciences, 1993, 16, pp 1-14.

GUIMARÃES, E. Os limites do sentido: um estudo histórico e enunciativo da linguagem. São Paulo: Pontes, 1995.

GUMPERZ, J. Discourse strategies. Cambridge: Cambridge University Press, 1982a.

Language and Social Identity. Cambridge: Cambridge University Press, 1982b.

On Interactional Sociolinguistic method. In: Talk, Work and institutional order: Discourse in medical, mediation and management settings. Ed. By: SARANGI, $S$ \& ROBERTS, C. Berlin/New York: Mouton de Gruyter, 1999.pp. 453-471.

Convenções de contextualização. Trad. José Luiz MEURER, \& Viviane Heberle. In: RIBEIRO, B \& GARCEZ, P (orgs.). Sociolinguística Interacional. São Paulo: Loyola, 2002.

Entrevista a Carlo Prevignano. In: EERDMANS, S. L; PREVIGNANO, C. L. \& THIBAULT, P. J. Language and Interaction. Discussions with John Gumperz. Amsterdam: John Benjamins, 2003. pp. 06-23. 
HALLIDAY, M. A. K.; HASAN, R. Cohesion in English. New York: Longman, 1976.

\& MATTHIESSEN, C. An Introduction to Functional Grammar. London: Hodder Arnold, 2004.

HEMAIS, B. \& BIASI-RODRIGUES, B. A proposta sócio-retórica de John Swales para o estudo de gêneros textuais. In: MEURER, J.L, BONINI, A \& MOTTA-ROTH, D. Gêneros teorias, métodos, debates. São Paulo: Parábola, 2005.

IVIC, I. Lev Semionovich Vygotsky. In: IVIC, I \& COELHO, E. P. Lev Semionovich Vygotsky. Recife: Fundação Joaquim Nabuco, 2010.

JAMES, W. Principles of psychology. New York: Holt \& Co, 1980.

KEMMIS, S \& McTAGGART, R. Participatory action research. In: DENZIN, N. K \& LINCOLN, Y.S. The sage handbook of qualitative research. London: Sage Publications, 2005.

KINTSCH, W. (1988). The role of knowledge in discourse comprehension: a constructionintegration model. Psychological Review, nº 95, 1988. pp. 163-182.

KLEIMAN, A. Texto e Leitor. Aspectos cognitivos da leitura. São Paulo: Pontes [1989a], 2009. 12 ed.

Leitura: ensino e pesquisa. São Paulo: Pontes, 1989 b.

O que é letramento? Modelos de Letramento e práticas de alfabetização na escola. In:

KLEIMAN, A. Os significados do letramento. São Paulo: Mercado de Letras, 1995.

Abordagens de Leitura. Scripta, Belo Horizonte, vol. 7, n 14, 2004. pp. 13-22.

Preciso "ensinar" o letramento? Não basta ensinar a ler e a escrever. CEFIEL/IEL/UNICAMP, 2005.

Letramento e suas implicações para o ensino de língua materna. In: Signo. Santa Cruz do Sul, v. 32 n 53, p. 1-25, dez, 2007.

KNOWLES, M. S. The adult learner. A neglected species. Huston, Texas: Gulf Publishing Company, 1973.

; HOLTON III, E. F \& SWANSON, R. A. The Adult Learner: The Definitive Classic in Adult Education and Human Resource Development, 6th ed. San Diego, Califórnia, USA, Elsevier, 2005.

KOCH, I. G. V. Linguística textual: quo vadis? In: Revista D.E.L.T.A., 17: ESPECIAL, 2001. pp. 11-23.

Desvendando os segredos do texto. São Paulo: Cortez, 2002.

Referenciação e orientação argumentativa. In: KOCH, I. V; MORATO, E. M e BENTES, A. C. Referenciação e Discurso. São Paulo: Contexto, 2005. pp 33-52. 
. Como se constroem e reconstroem os objetos-de-discurso. In: Revista Investigações. v. 21, n. 2, 2008. pp. 99-114.

Linguagem e cognição: a construção e reconstrução de objetos-de-discurso. In: Revista Veredas, v. 06, n. 01, 2009a. pp. 29-42.

Introdução à Linguística Textual. São Paulo: Martins Fontes, 2009b.

Argumentação e Linguagem. São Paulo: Cortez, 2009c. 12 ed.

A Inter-ação pela linguagem. São Paulo: Contexto, 2012.

As tramas do texto. São Paulo: Contexto, 2014.

\& MARCUSHI, L. A. Processos de Referenciação na Produção Discursiva. In:

DELTA, São Paulo , v. 14, Especial Issue, 1998. Disponível em: http://www.scielo.br/scielo.php?pid=S0102-44501998000300012\&script=sci_arttext, acesso em 13/08-2015.

\& ELIAS, V. Ler e compreender: os sentidos do texto. São Paulo: Contexto, 2006.

KRESS, G. R. e van LEEUWEN, T. Reading Images: a Grammar of Visual Design. Londres: Routledge, 2006 [1996].

KRUEGER, R. A; CASEY, A. C. Focus Group: a practical guide for applied research. Los Angeles: Sage Publications, 2015. 5 ed.

LAKOFF, G \& JOHNSON, M. Metáforas de la vida cotidiana. Madrid. Ediciones Cátedra, [1986] 2012.

LEFFA, V. Aspectos da Leitura. Porto Alegre: Sagra - D.C. Luzzatto, 1996a.

LEFFA, Vilson Jose. Fatores da Compreensão na Leitura. Cadernos do IL, Porto Alegre, v.15, n.15, p.143-159, 1996 b.

LEVINSON, S. G. Pragmática. São Paulo: Martins Fontes, 2007. Trad. Luís Carlos Borges e Aníbal Mari.

LEWIN, S. Pesquisa de ação e problemas de minoria. In: LEWIN, K. Problemas de dinâmica de grupo. São Paulo: Cultrix, [1946] 1970. Disponível em: http://www.continents.com/Art104.htm, acesso em: 02/04/2015.

LIMA, S. M. C \& FELTES, H. P. M. A Construção de referentes no texto/discurso: um processo de múltiplas âncoras. In: CAVALCANTE, Mônica Magalhães, M \& LIMA, S. M. C (Orgs). Referenciação: teoria e Prática. São Paulo: Cortez, 2013. pp. 30-58.

LUDOJOSKI, R. L. Andragogia o educacion del adulto. Buenos Aires: Editorial Guadalupe, 1972.

LURIA, A. A construção social da mente. São Paulo: Ícone, 1992. Trad. Marcelo Brandão Cipolla. 
MARCUSCHI, L. A. Gêneros textuais emergentes no contexto da tecnologia digital. In: MARCUSCHI, L. A. \& XAVIER, A. C. (Orgs.) Hipertexto e gêneros digitais. Rio de Janeiro: Editora Lucerna, 2004.

. Cognição, linguagem e práticas interacionais. Rio de Janeiro: Lucerna, 2007a.

Análise da Conversação. 6. ed. São Paulo: Ática, 2007b.

Produção textual, análise de gêneros e compreensão. São Paulo: Parábola, 2008.

Gêneros Textuais: definição e funcionalidade. In: DIONÍSIO, A.P; MACHADO, A.

R \& BEZERRA, M. A. Gêneros textuais e ensino. São Paulo: Parábola, 2010.

Linguística de Texto: o que é e como se faz? São Paulo: Parábola, 2012.

MILLER, C. R. Genre as Social Action. In: Quarterly journal of speech. N. 70, 1984, pp. 151-167.

MOLLICA, M. C. Fala, Letramento e Inclusão Social. São Paulo: Contexto, 2007.

MONDADA, L \& DUBOIS, D. Construção dos objetos de discurso e categorização: uma abordagem dos objetos de referenciação. In: CAVALCANTE, M. M.; RODRIGUES, B.B \& CIULLA, A (orgs). Referenciação. São Paulo: Contexto, 2003. pp. 17-52.

MORALES, P. Que pretende Paulo Freire: su filosofia del hombre y de la educacion. In: OLABUENAGA, J.I.R.; MORALES, $\mathrm{P}$ \& MARROQUIN, M. Paulo Freire: Concientización y andragogía. Buenos Aires: Paidós, 1975.

MORGAN, D. Focus group as qualitative research. Qualitative Research Methods Series. 16. London: Sage Publications, 1977.

MORATO, E. M. Linguagem e Cognição. São Paulo: Plexus Editora, 2002. 2 ed.

O caráter sociocognitivo da metaforicidade: contribuições do estudo do tratamento de expressões formuladas por pessoas com afasia e com doença de alzheimer. Revista de Estudos Linguísticos, Belo Horizonte, vol. 16, n. 1, p. 157-177, jan./jun. 2008.

A noção de frame no contexto neurolinguístico: o que ela é capaz de explicar? In: Cadernos de Letras da UFF - Dossiê: Letras e cognição no 41, 2010. pp. 93-113.

Contribuições da Neurolinguística para a Linguística Aplicada - e vice-versa. In: Revista (Con)Textos Linguísticos, Vitória, v.8, n. 10.1, 2014. pp. 293-314.

MIRANDA, N. S. O caráter partilhado da construção da significação. Veredas, revista de estudos linguísticos. Juiz de Fora, 2001,v. 5, n. 1 p. 57 a 81.

PRINCE, E. F. Toward a Taxonomy of Given-New Information, In: COLE, P. (ed.). Radical Pragmatics. New York: Academic Press, 1981.

RAMOS, A. A. L. Um caminho estrangeiro para a compreensão dos gêneros: estratégias cognitivas em produção textual do CELP-BRAS. Tese (Doutorado em Linguística). 
Universidade de Brasília, 2007.

ROJO, R. Letramentos Múltiplos, escola e inclusão social. São Paulo: Parábola, 2009.

Pedagogia dos Multiletramentos. In: ROJO, R. \& MOURA (Orgs.)

Multiletramentos na escola. São Paulo: Parábola, 2012. pp. 07-31.

\& BARBOSA, J. P. Hipermodernidade, multiletramentos e gêneros discursivos.

São Paulo: Parábola, 2015.

ROSCH, E. Principles of categorization. In: E. ROSCH \& B.B LLOYD. (Eds.) Cognition and categorization. Hillsdale, N.J.: Lawrence Erlbaum, 1978.

SALOMÃO, M. M. Razão, Realismo e Verdade: o que nos ensina o estudo sociocognitivo da referência. In: KOCH, I. V; MORATO, E. M e BENTES, A. C. Referenciação e Discurso. São Paulo: Contexto, 2005, p.p 152-168.

SANTOS, Z. B \& PIMENTA, S.M.O. Da semiótica social à multimodalidade: a orquestração de significados. In: CASA: Cadernos de Semiótica Aplicada, v.12, n.2, 2014, pp. 295-324.

SCHENEUWLY, B. Gêneros e tipos de discurso: considerações psicológicas e ontogenéticas. In: SCHENEUWLY, B \& DOLZ, J. Gêneros orais e escritos na escola. Trad. e org. Roxane Rojo e Gláis Sales Cordeiro. Campusnas, SP: Mercado das Letras, 2004.

\& DOLZ, J. Os gêneros escolares - das práticas de linguagem aos objetos de ensino. In: SCHENEUWLY, B \& DOLZ, J. Gêneros orais e escritos na escola. Trad. e org. Roxane Rojo e Gláis Sales Cordeiro. Campusnas, SP: Mercado das Letras, 2004.

SEARLE, R. John. 1969. Speech acts. Cambridge: Cambridge University Press, 1969.

SILVESTRE, C. Multimodalidade e literacia. In: VIEIRA, J \& SILVESTRE, C. Introdução à Multimodalidade Contribuições da Gramática Sistêmico-Funcional Análise de Discurso Crítica/Semiótica Social. Brasília: CIP, 2015.

SOARES, M. Letramento: um tema em três gêneros. Belo Horizonte: Autêntica, 2009.

SPERBER, D \& WILSON, D. Relevance: Communication and Cognition. Oxford: Blackwell Publishers, 1995. 2 ed.

STREET, B. Literacy in Theory and practice. Cambridge: Cambridge University Press, 1984. 1993.

Cross-Cultural approaches to literacy. Cambridge: Cambridge University Press,

STREET, Brian. Perspectivas Interculturais sobre o Letramento. In: Filologia, linguistic. Port., $\mathrm{n}^{\circ}$ 08, 2006. pp. 465-488. 
Letramentos Sociais: abordagens do letramento no desenvolvimento, na etnografia e na educação. São Paulo: Parábola, 2014. Trad. Marcos Bagno.

SWALES, J. M. Genre Analysis: English in academic and research settings. Cambridge: Cambridge University Press, 1990.

THIOLLENT, M. Metodologia da pesquisa-ação. São Paulo: Cortez, 2011. 18 ed.

THOMAS, J. Meaning in interaction: an introduction to Pragmacts. London: Longman, 1995.

TANNEN, D. Interactional Sociolinguistics. In: Sociolinguistes: An International Handbook of the Science of Language anf Society. Ed. By AMMON, U; DITTMAR, N; MATTHEIER, K \& TRUDGILL, P. Berlin and New York: Walter de Gruyter, 2004.

\& WALLAT, C. Interactive frames and knowledge structure schemas in interaction: examples from a pediatric examination. Social Psychology Quarterly, 1987, Vol;. $\quad 50, \quad \mathrm{n}^{\mathrm{o}} \quad 2, \quad$ p. 205-216. Disponível em < http://www9.georgetown.edu/faculty/tannend/TANNEN\%20ARTICLES/scans\%20of\%20Ta nnen\%20Articles/1987/Interactive\%20Frames\%20and\%20Knowledge\%20Schemas\%20in\% 20Interaction.pdf . Acesso em 30/08/2015.

TFOUNI, L. Letramento - mosaico multifacetado. In: TFOUNI, L. (Org.). Letramento, escrita e leitura. São Paulo: Mercado de Letras, 2010.

TOMASELLO, M. Origens Culturais da aquisição do conhecimento humano. São Paulo: Martins Fontes, 2003.

Origins of human communication. Cambridge: University Press, 2008.

Wy we cooperate. Boston: Mit Press, 2009.

TRIPP, D. Pesquisa-ação: uma introdução metodológica. In: Educação e Pesquisa, São Paulo, v. 31, n. 3, set./dez. 2005, p. 443-466.

VAN DIJK, T. A. Discourse and cognition in society. In: CROWLEY, D. \& MITCHELL, D. Communication Theory Today. Oxford, Blackwell, 1992.

Discourse and Context: a sociogognitive approach. New York, Cambridge University Press, 2008.

Society and Discourse: How Social Contexts Influence Text and Talk. New York: Cambridge University Press, 2009.

Cognição, Discurso e Interação. São Paulo: Contexto, 2010.

VAN LEEUWEN, T. Introducing Social Semiotics. London: Routledge, 2005.

VIEIRA, J. Multimodalidade e eventos de letramento. In: VIEIRA, J \& SILVESTRE, C. Introdução à Multimodalidade Contribuições da Gramática Sistêmico-Funcional Análise de Discurso Crítica/Semiótica Social. Brasília: CIP, 2015. 
VOGT, C. Linguagem, Pragmática e Ideologia. São Paulo: Hucitec/Funcamp, 1980.

VOGT, M. S. L \& ALVES, E. D. Revisão Teórica sobre a educação de adultos para uma aproximação com a andragogia. In: Educação. Santa Maria, v. 30, n. 02, 2005. pp. 195214.

VYGOTSKY, L. S. Pensamento e Linguagem. Edição eletrônica: Ed. Ridendo Castigat Mores, [1934]2001. Disponível em: http://www.ebooksbrasil.org/adobeebook/vigo.pdf

A Formação Social da Mente. São Paulo: Martins Fontes, 1991.

Mind in Society: Development of Higher Psychological Processes. Cambridge, Massachusetts: Harvard University Press, 1978.

WARNEKEN, F \& TOMASELLO, M. Cognition for culture. In: ROBBINS, P \& AYDEDE, M. The Cambridge Handbook of Situated Cognition. New York: Cambridge University Press, 2009. pp. 467-479

WILSON, V. Teoria dos atos de fala. In: Martelotta, M.E. (org.) Manual de linguística. São Paulo: Contexto, 2008, pp.92 -96.

WOOD, D., BRUNER, J. S. and ROSS, G. The role of tutoring in problem solving. Journal of Child Psychology and Psychiatry, 1976, 17: 89-100.

ZANOTTO, M. S. de P. A construção e a indeterminação do significado metafórico no evento social de leitura. In: Paiva, V.L. Metáforas do cotidiano. Belo Horizonte: Ed. do Autor, UFMG, 1998. 


\section{INSTITUTO DE CIENCIAS HUMANAS / UNIVERSIDADE Q Protoforma DE BRASÍLIA / CAMPUS}

\section{PARECER CONSUBSTANCIADO DO CEP}

\section{DADOS DO PROJETO DE PESQUISA}

Título da Pesquisa: ATIVIDADES DE PRODUÇÄO E COMPREENSÃo TEXTUAL NO ENSINO TÉCNICO: ESTUDO SOCIONTERACIONAL DA REFERENCIAÇẨO E INFERENCIAÇÃO.

Pesquisador: Alinne Santana Ferreira

Área Temática:

Versão: 3

CAAE: 38470614.7 .0000 .5540

Instituição Proponente: FUNDACAO UNIVERSIDADE DE BRASILIA

Patrocinador Principal: Financiamento Próprio

\section{DADOS DO PARECER}

Número do Parecer: 900.358

Data da Relatoria: $11 / 12 / 2014$

Apresentação do Projeto:

Trata-se de um estudo de doutorado em linguistica que pretende analisar processos de produção textual junto a com estudantes do Instituto Federal de Brasilia. Serão realizadas aulas gravadas com os estudantes, considerados participantes da pesquisa-acao desenvolvida.

\section{Objetivo da Pesquisa:}

O objetivo geral da pesquisa 'e compreender como ocorre o processo de referenciaçäo/inferenciaçäo na produção de textos escritos e orais em atividades de produção/compreensão textual, bem como avaliar suas implicaçöes na construção do letramento escolar.

Os objetivos especificos sao: i. Investigar como o processamento das expressöes referenciais/indexicais contribui para a construção de sentido do texto quando os alunos realizam as inferências; ii. Revelar como o fornecimento de pistas verbais e não verbais pela professora pesquisadora, durante as discussões, levam os alunos fazer as inferências e, consequentemente, a construir o sentido do texto; iii. Analisar o grau de conhecimento contextual dos alunos nos processos de referenciaçäo e de categorização/recategorizaçäo, tendo em vista o desenvolvimento de estratégia para ampliar esse conhecimento e visando à melhoria do processo de produção/compreensão textual; iv. Revelar como o trabalho com a diversidade de gêneros

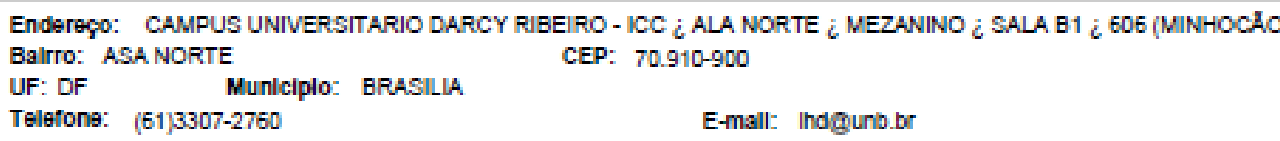




\section{INSTITUTO DE CIENCIAS HUMANAS / UNIVERSIDADE DE BRASÍLIA / CAMPUS}

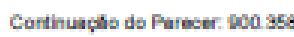

textuais, em sua maioria multimodais, corrobora com a ampliaçăo de conhecimentos linguísticos e extralinguísticos e, consequentemente, com a construçăo de um letramento crítico; v.Propor atividade didático-pedagógica para desenvolver a competéncia de processamento textual relativa aos processos de inferenciação e referenciação.

Avaliaçäo dos Riscos e Beneficios:

A pesquisadora avalia que os riscos săo mínimos, visto que os participantes säo todos maiores de idade e assinaräo os termos obrigatórios da pesquisa.

Comentários e Consideraçöes sobre a Pesquisa:

Os dados desta pesquisa seräo gerados por meio de gravaçäo de vídeo e áudio das interaçōes realizadas em sala de aula de um campus do Instituto Federal de Brasilia, que seräo transformadas em arquivos MP4. a serem editados, transcritos e analisados posteriormente. As filmagens serão realizadas durante 05 (cinco) aulas de Leitura e Produção de Texto da professora pesquisadora, nas nas quais a professora discutirá os sentidos do(s) texto(s) analisado(s) pelos alunos na aula anterior, sem a colaboração da professora. Primeiramente, os alunos irão fazer leitura individualizada e produçāo de parágrafos nos quais irão tecer comentários a respeito do texto. Esse material escrito, produzido pelos colaboradores de pesquisa, será recolhido e fotocopiado pela professora-pesquisadora. Na aula posterior, a professora irá fazer leitura mediada, e os alunos começarão a partilhar as suas inferências. Esse momento será filmado, pois as pistas verbais e näo verbais constituiräo pontos de análise muito importantes por revelarem como os sentidos do texto serảo construídos, des-construídos e re-constuídos pelos interagentes. Como estratégia para o visionamento da pesquisa, serăo feitas reuniöes com os alunos envolvidos, objetivando compreender como os colaboradores interpretam as ações sociais, fazendo com que os dados sejam interpretados sob a ótica do pesquisador e de seus colaboradores.

Consideraçöes sobre os Termos de apresentação obrigatória:

A pesquisadora apresenta TCLE dentro das exigências da regulamentação da ética em pesquisa no Brasil. Apresenta, ainda, Termo de Autorização para Uso de Imagem e Som adequado.

Recomendações:

Conclusões ou Pendências e Lista de Inadequações:

Sugiro que o projeto seja considerado aprovado.

Situação do Parecer:

Aprovado

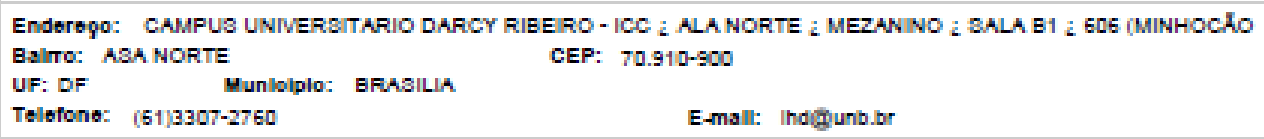




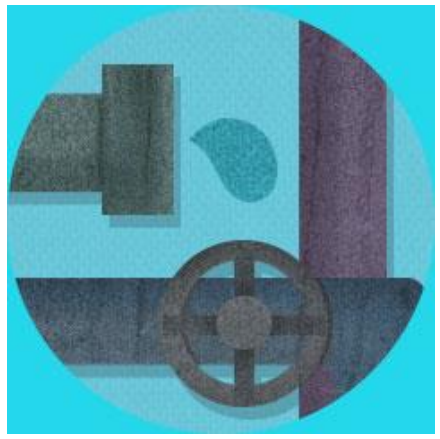

\section{O FUNDO DO POÇO}

O banho demorou demais, a chuva caiu de menos e, quando a população percebeu, já era tarde demais. Relembre como começou (e onde vai parar) a crise de água em São Paulo. POR OTAVIO COHEN

O primeiro sinal veio em 2004. Foi nesse ano que a Sabesp, empresa de abastecimento de São Paulo, renovou a autorização para administrar a água na cidade. Mas tinha alguma coisa errada: a estrutura dos reservatórios parecia insuficiente para dar conta de tanta demanda e seria preciso realizar obras para aumentar a capacidade de armazenamento de água. De acordo com os planos da Sabesp, a cidade de São Paulo ficaria bastante dependente do Sistema Cantareira, o que era preocupante. Se a água dos tanques do sistema acabasse, seria o caos. E foi. Em julho de 2014, o volume útil da Cantareira, que atende 8,8 milhões de pessoas na Grande SP, esgotou. Com o esvaziamento do reservatório e as previsões pessimistas de falta de chuva, São Paulo se afogou na maior crise hídrica dos últimos 80 anos.

O Sistema Cantareira é um conjunto de represas criado nos anos 1970 como resposta ao rápido crescimento populacional em São Paulo. As represas ficam nas nascentes da bacia do Rio Piracicaba, a cerca de 70 quilômetros da capital. Para manter os reservatórios cheios, o sistema depende das chuvas de verão. Acontece que, nos primeiros três meses de 2014, choveu menos da metade do esperado para o período. A estiagem não foi de uma hora para a outra. Desde 2013, a chuva já estava abaixo da média na região. E olha que, dois anos antes, choveu tanto que o sistema operava com um nível superior a $100 \%$.

Mas a culpa da crise na maior cidade do Brasil não é só da instabilidade de São Pedro. Ele jamais poderia prever, por exemplo, que a população crescesse tanto. 
De 4,8 milhões em 1960, o número de habitantes da capital pulou para 11,8 milhões em 2013. Isso só a capital mesmo, sem contar as outras cidades da região metropolitana. A urbanização, que aumenta a poluição dos rios e dificulta o acesso à água potável, também entrou na mistura, junto com todos aqueles outros vilões que a gente já conhece: verticalização, impermeabilização do solo, falta de planejamento, sobrecarga do sistema de abastecimento e coleta. A Sabesp estima que, em São Paulo, $25 \%$ da água se perca no caminho entre a distribuidora e as torneiras das casas. Segundo reportagem do Estadão, essa perda pode chegar a $31 \%$.

Para diminuir o problema, em maio, a Sabesp decidiu usar o volume morto, uma reserva de 400 bilhões de litros que fica abaixo das comportas que retiram água do Sistema Cantareira. Foram feitas obras para bombear mais de 180 bilhões de litros dessa reserva. , mas até que resolveu. Por um tempo. A previsão da Agência Nacional das Águas (ANA), órgão federal responsável pela gestão dos recursos hídricos brasileiros, é de que a reserva dure até novembro. A Sabesp pretende fazer obras para bombear mais alguns bilhões de litros do volume morto, para garantir o abastecimento por mais alguns meses. A estimativa mais otimista é de que haja água suficiente até março de 2015. Depois disso, a esperança é a chuva. Se chover como o previsto a partir de outubro de 2014, o Sistema Cantareira pode voltar a operar com $30 \%$ de seu volume. Não é muita coisa, mas é o melhor dos cenários. $\mathrm{E}$ o pior?

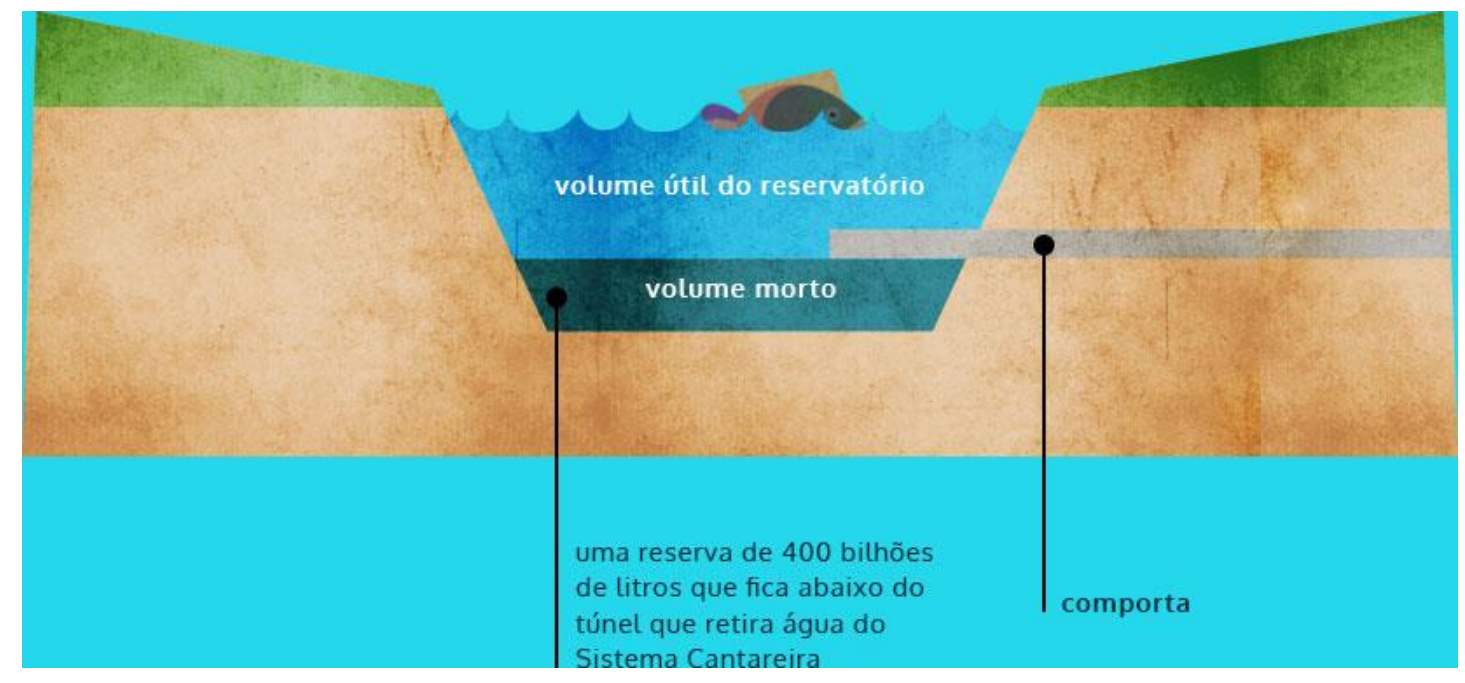

A Califórnia vive uma crise de água parecida com a de São Paulo. Ao longo de 2013, choveu por lá um terço da água que caiu em São Paulo nos seis primeiros meses de 2014. Chegou um ponto em que o governo declarou estado de emergência e começou a tomar medidas para preservar os recursos e evitar desperdício. Os cidadãos entraram num regime de economia de água parecido com o racionamento de energia que o Brasil viveu em 2001. Quem for flagrado em situações de desperdício, como lavar calçada com mangueira ou deixar a irrigação do jardim ligada o dia todo, terá que pagar uma multa de 500 dólares. 
Não é só ameaça. Desde abril, só a cidade de Santa Bárbara já arrecadou mais de 1 milhão de dólares em multas. É possível acessar informações sobre desperdício de água e conferir o nível dos reservatórios da Califórnia em tempo real. A previsão para o fim da água lá é entre (bem mais do que aqui, aliás).

Por aqui, em vez de um racionamento, ficou decidido que quem economizar em pelo menos $20 \%$ terá um desconto de $30 \%$ na conta de água. A Sabesp também diminuiu a pressão do abastecimento e começou uma campanha de conscientização com a população. Mas desde o fim da Copa do Mundo, moradores de alguns bairros já sentem o efeito da crise quando falta água nas torneiras e chuveiros.

Mesmo se chover mais do que qualquer meteorologista é capaz de prever, mesmo se a população compreender a necessidade urgente de uma redução drástica no consumo de água, ainda será preciso haver um plano de gestão mais eficiente. $\mathrm{A}$ recuperação do nível do Sistema Cantareira pode levar até 10 anos. Enquanto isso, a população vai continuar a crescer. Em algumas décadas, pode ser que nem os reservatórios atuais cheios deem conta do recado.

\section{BAIXO NÍVEL}

Navegue pelo gráfico e veja como o nível dos reservatórios mudou na última década. Apesar do nível baixo nas épocas de secas, nunca houve tão pouca água como em 2014.

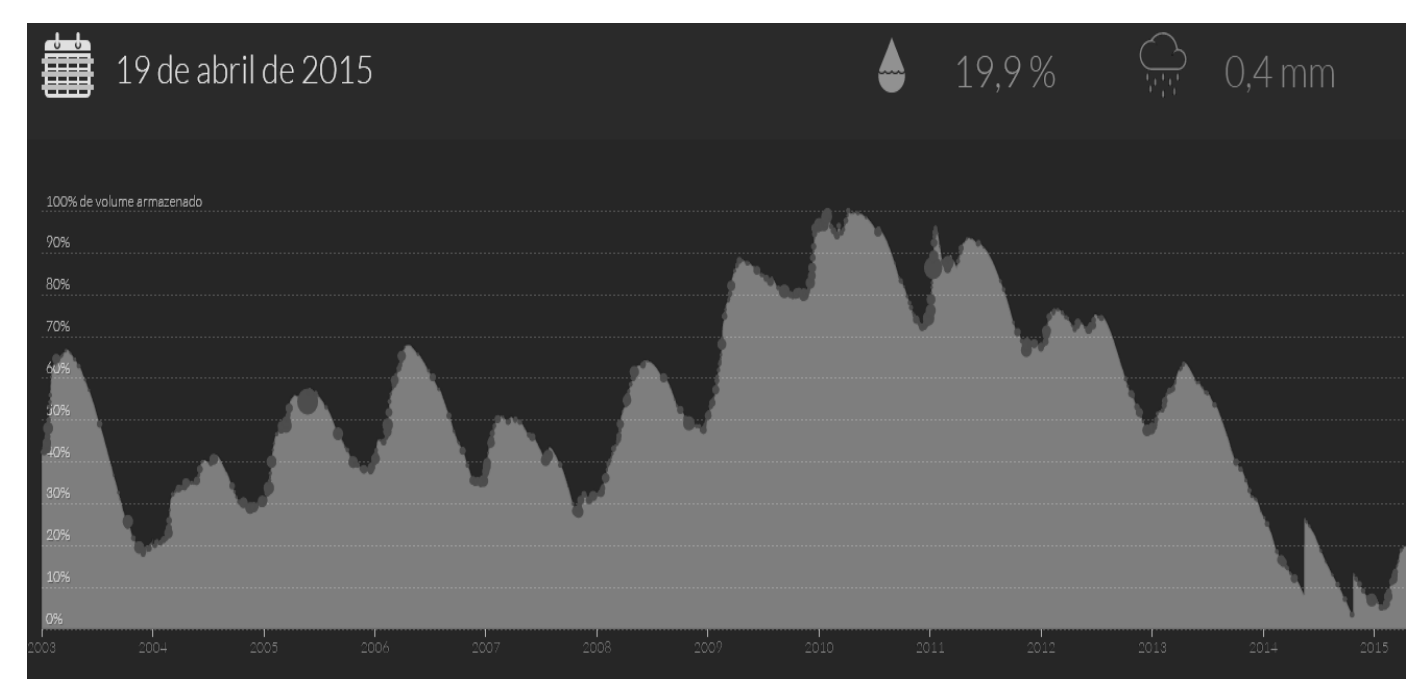




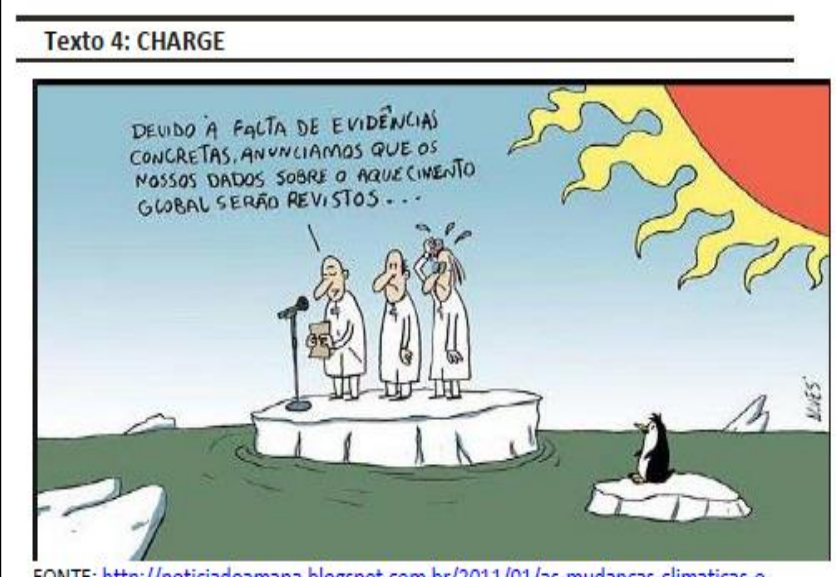

FONTE: http://noticiadoamapa.blogspot.com.br/2011/01/as-mudancas-climaticas-esuas.html

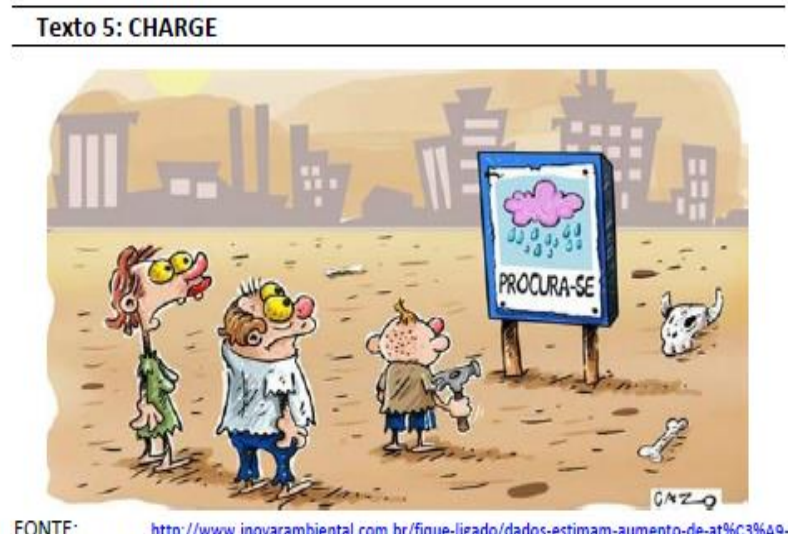

6\%C2\%BOc-no-brasil-a-longo-prazo-recursos-h\%6C3\%ADdricos-tendem-a-diminuir.aspx

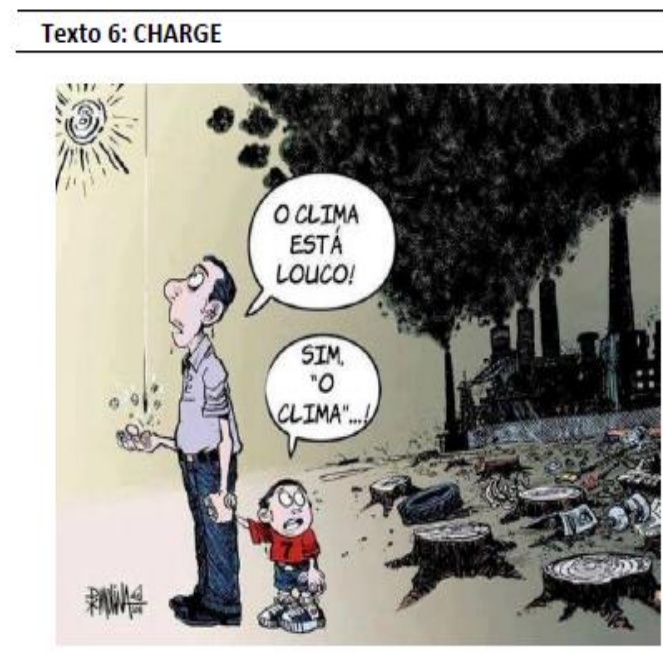

FONTE: http://www.silvaporto.com.br/blog/?p=2842

\section{ATIVIDADES PROPOSTAS}

1) Qual é o tema apresentado nas charges?

2) Qual é a crítica realizada por cada uma delas?

3) Quais as caracteristicas do gênero charge?

4) É possivel relacionar as charges com o texto "Mídia e mudança climática"?

5) Explique o uso da crase na primeira charge a partir das observaçôes no final do nosso material. 


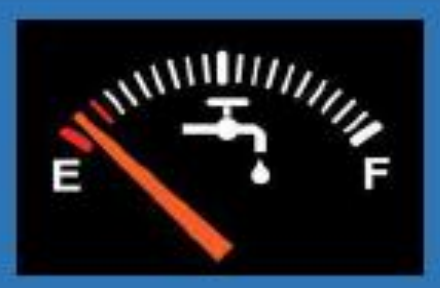

Crise Hídrica

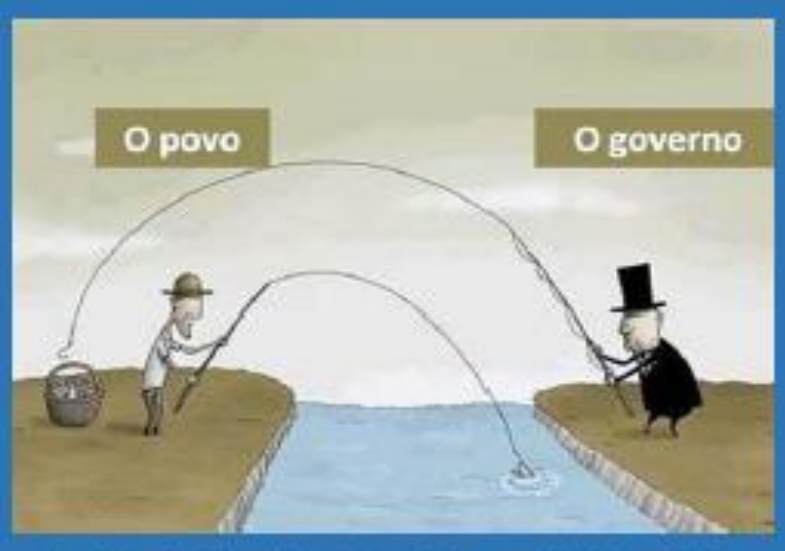

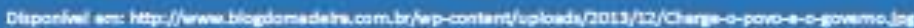



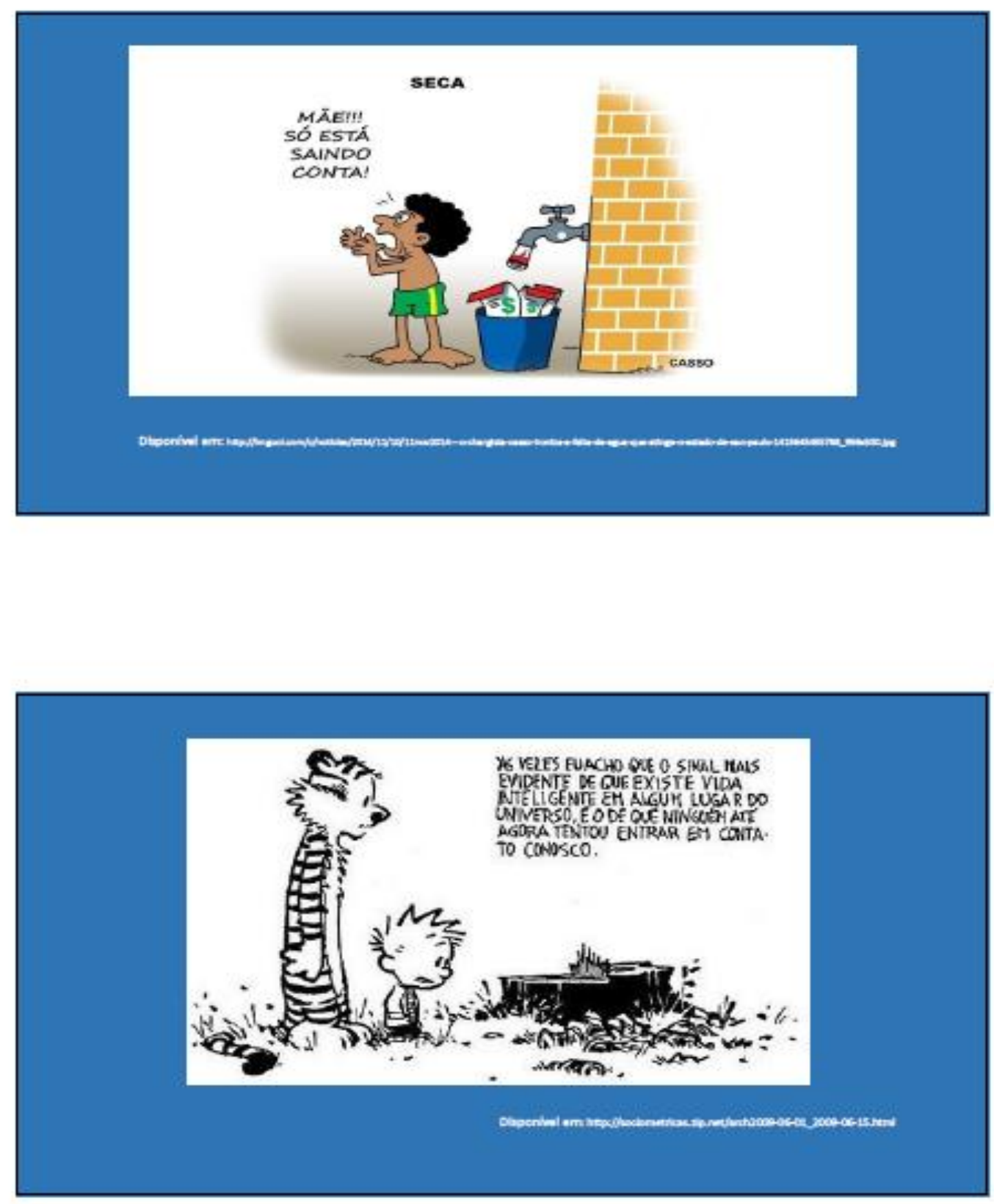

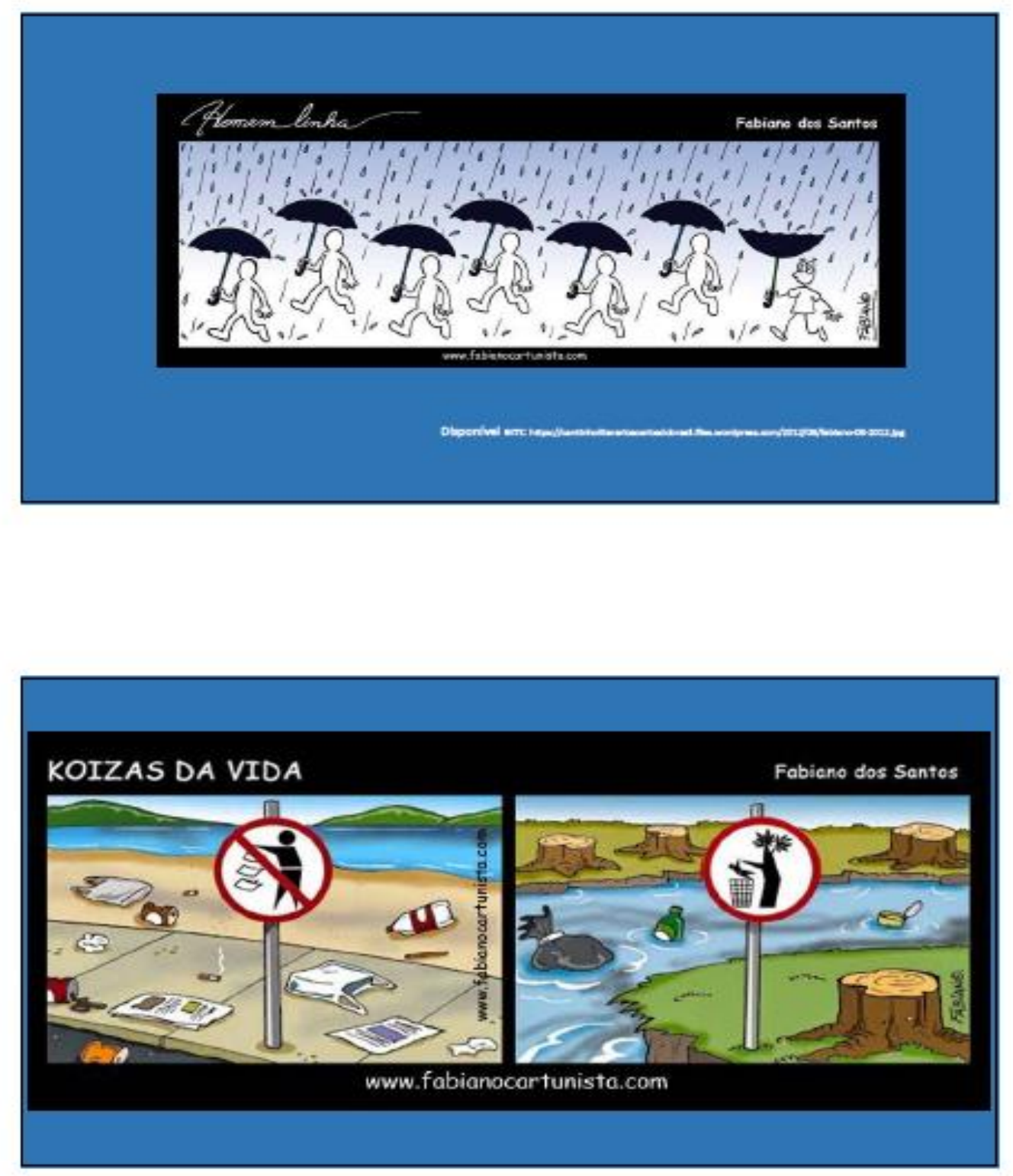


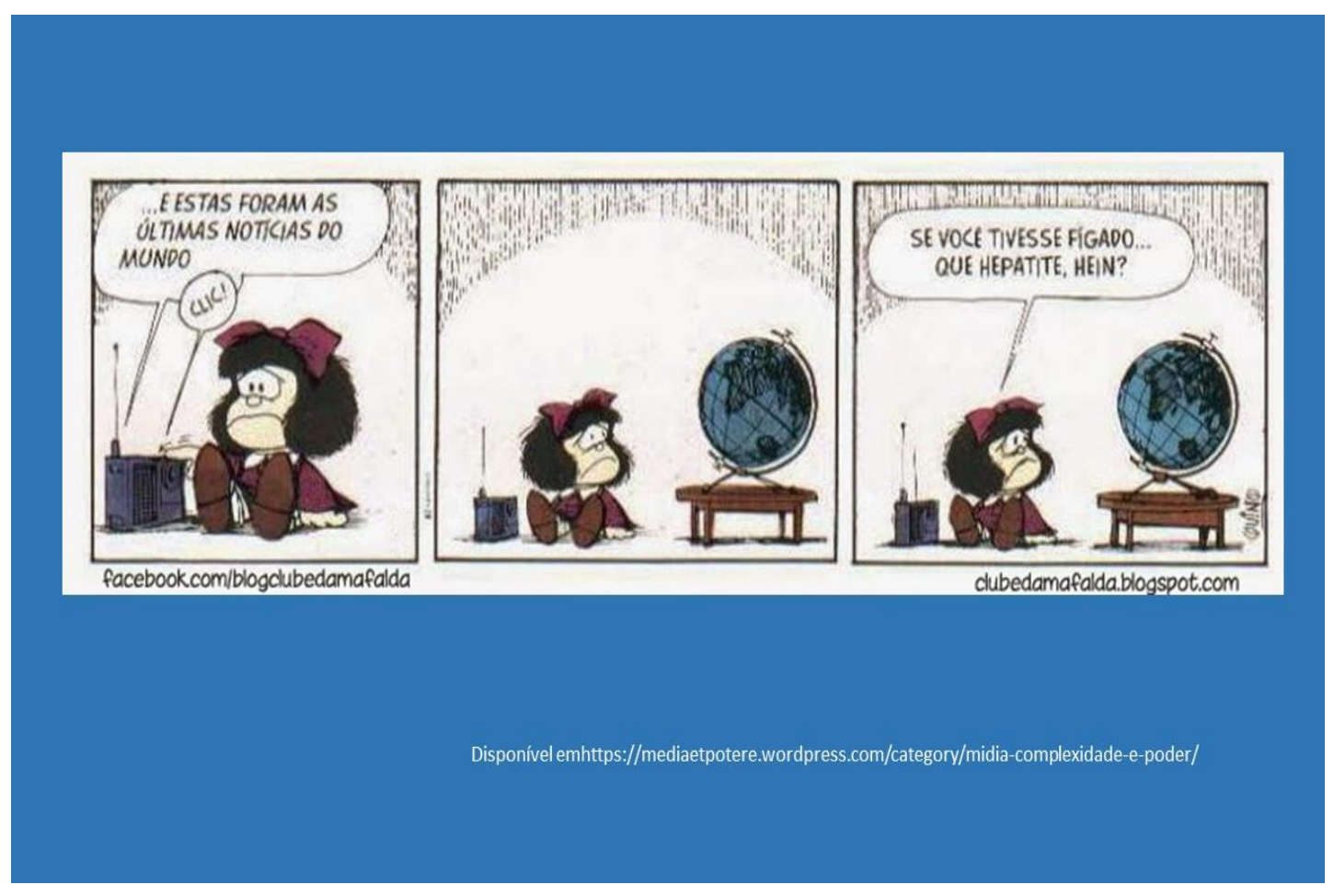




\section{INSTITUTO FEDERAL}

BRASÍLIA

Campus São Sebastiäo

Instituto Federal de Educação, Ciência e Tecnologia de Brasília - Campus São Sebastião.

Curso de Técnico em Secretariado Escolar Turma:

Professora: Maria Eneida

Componente Curricular: Leitura e Produção de Textos

Aluno:

Data: / 2015.

\section{Atividade de Leitura e Produção de Textos}

Valor: 1,0 ponto

1) Leia os textos que seguem e escreva um parágrafo sobre o que compreendeu em cada um deles.

a)

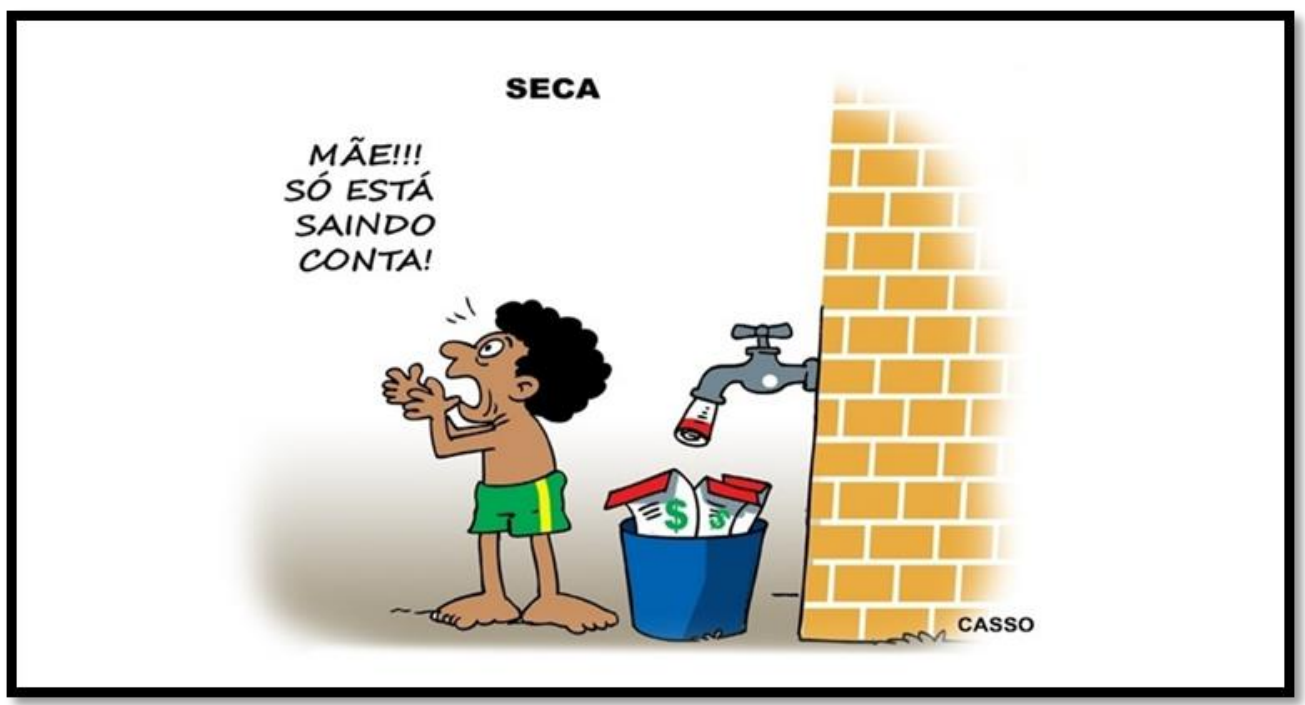

Disponível em: http://imguol.com/c/noticias/2014/11/10/11 nov2014---o-chargista-casso-ironiza-a-falta-de-agua-que-atinge-oestado-de-sao-paulo-1415645435788_956x500.jpg 
b)

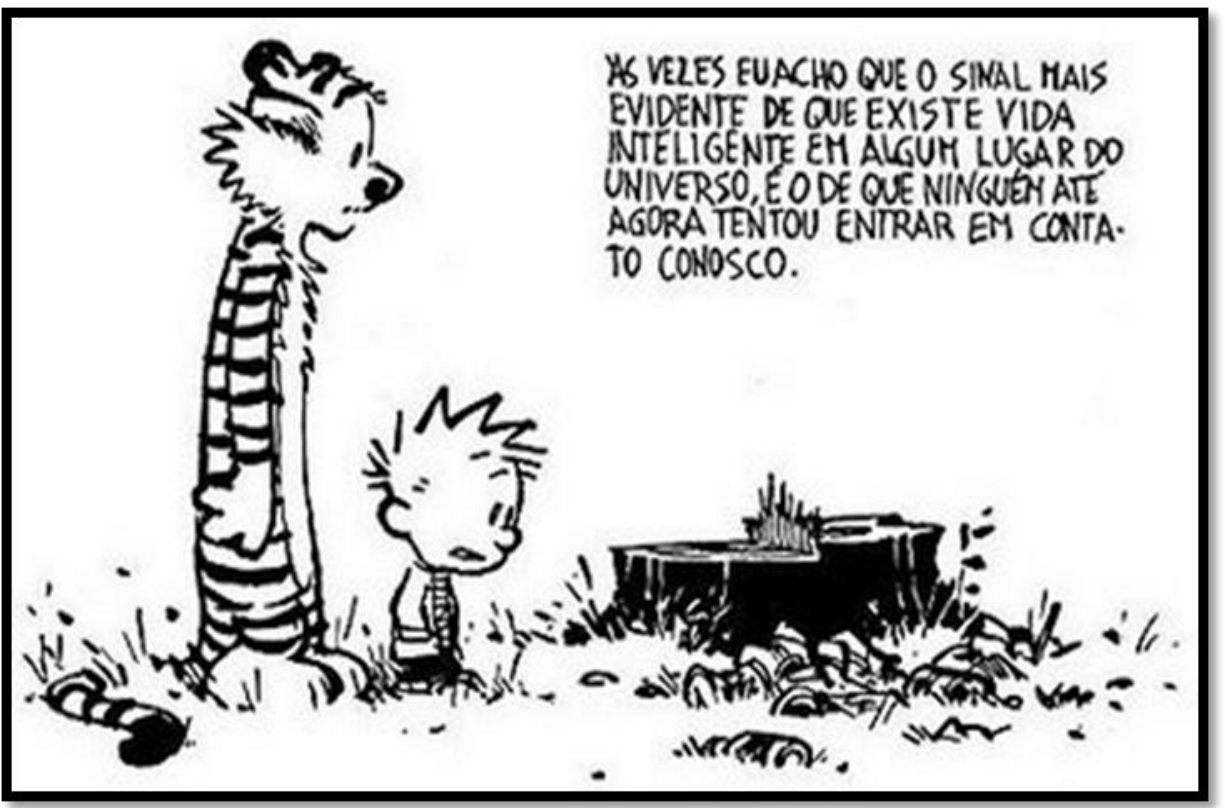

Disponível em: http://sociometricas.zip.net/arch2009-0 
c)

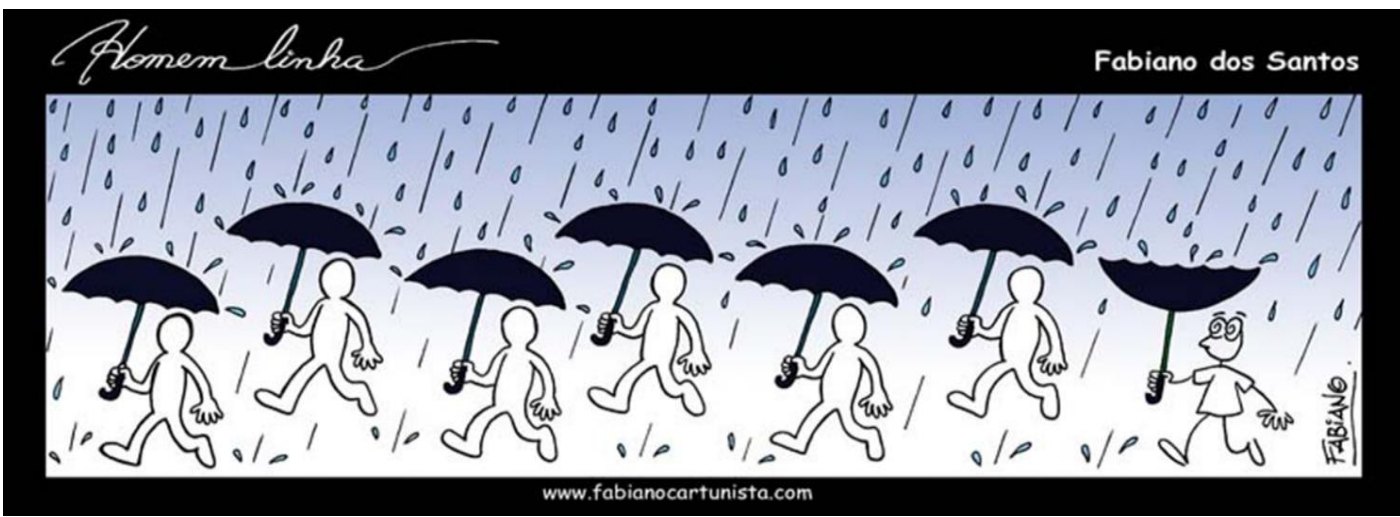

Disponível em: https://cantinholiterariososriosdobrasil.files.wordpress.com/2012/08/fabiano-08-2012.jpg

d)

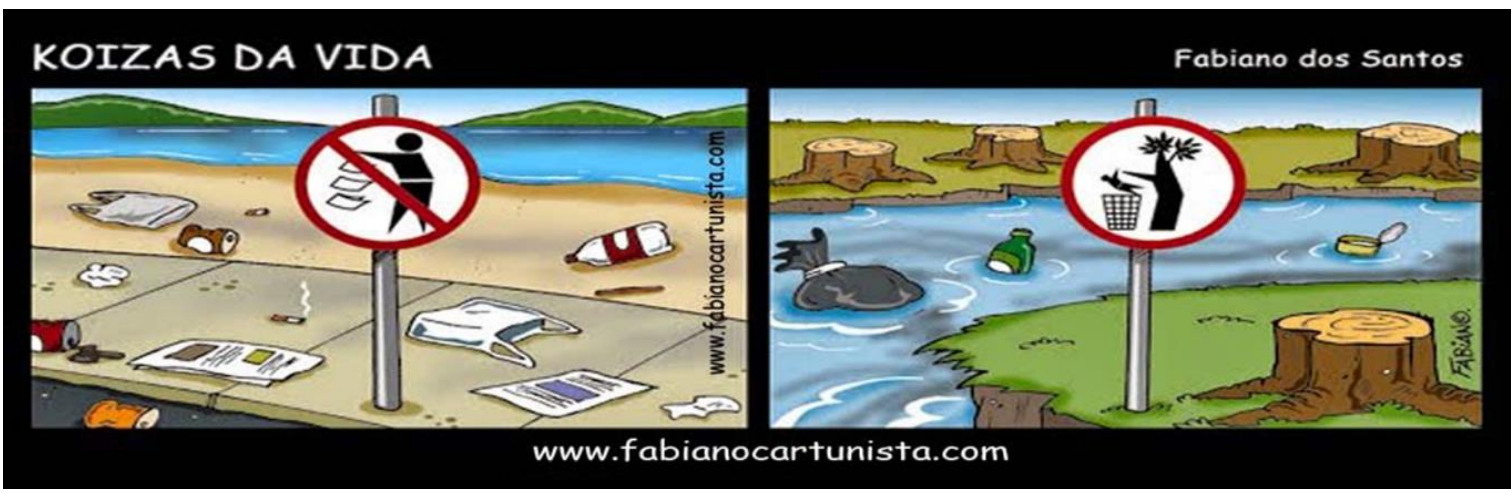

BOM TRABALHO! 


\section{Crise Hídrica}

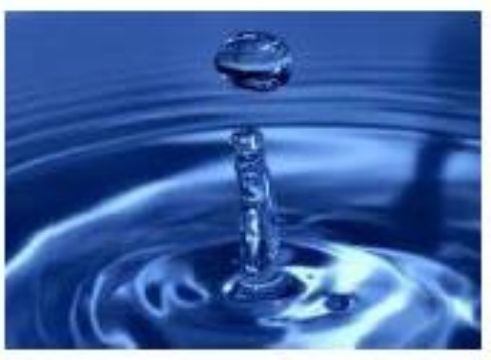

Gêneros Textuais apresentados:

- Anúncio publicitário

-Boletim Informativo

-Manchete de Jornal/Revista 

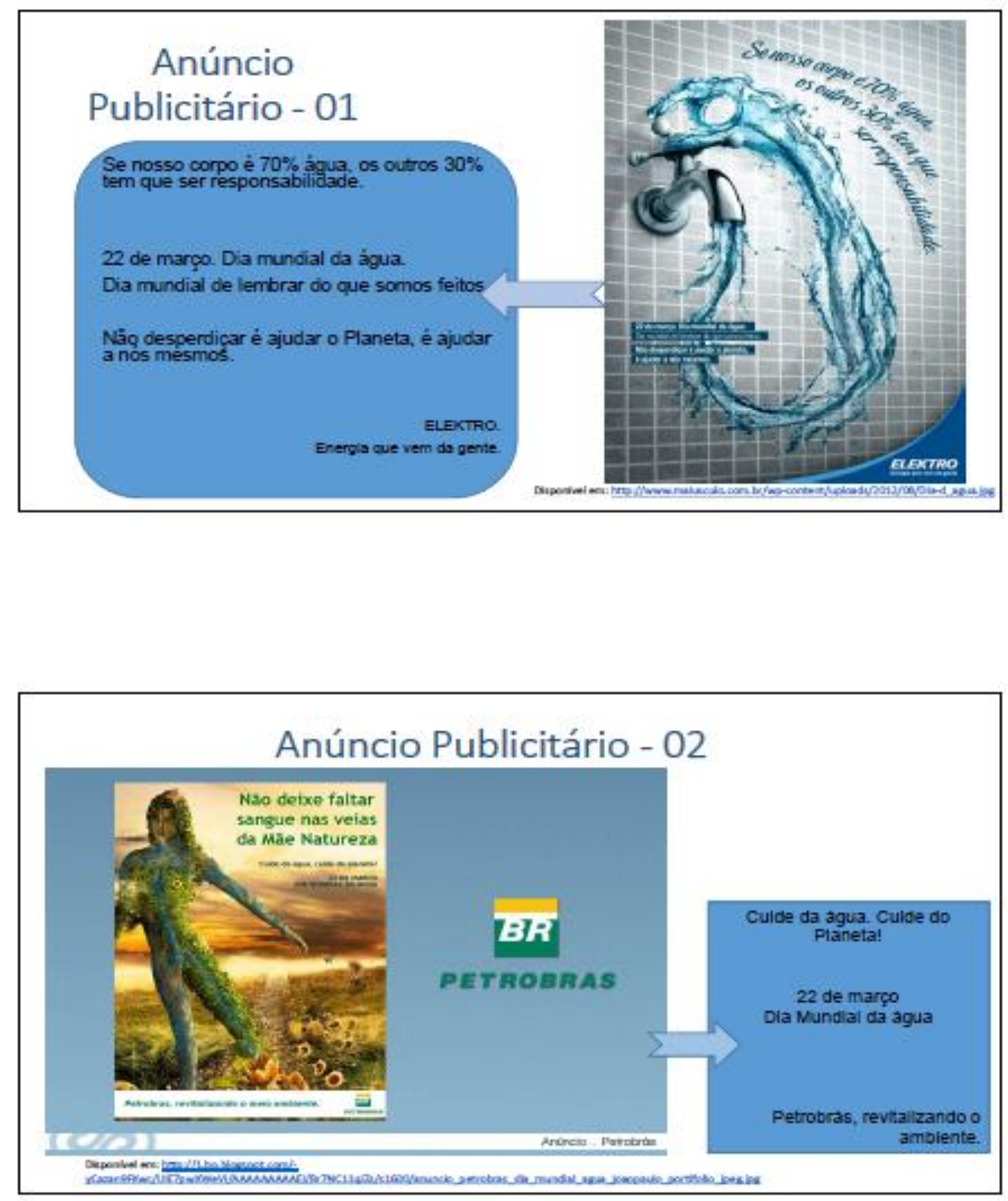


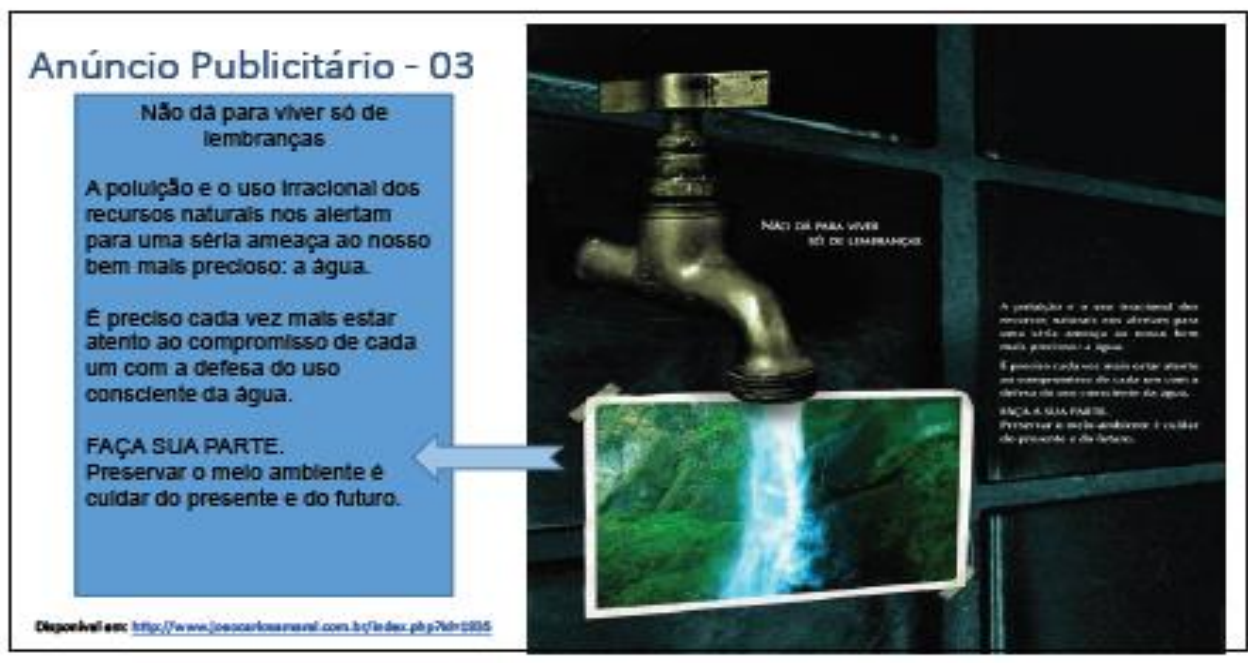

Boletim Informativo 1: Rádio Nova Brasil FM

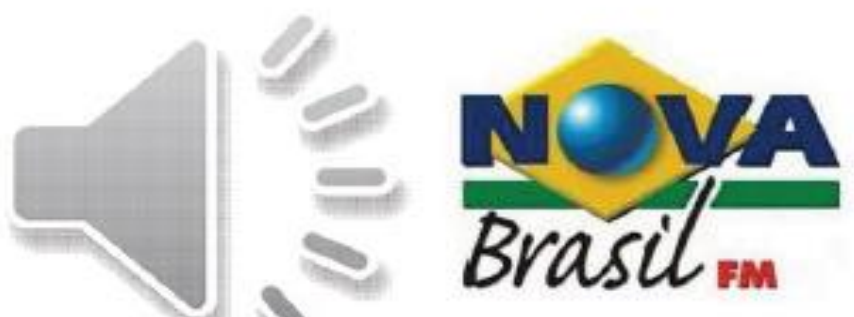


Boletim Informativo 2: Rádio Nova Brasil FM
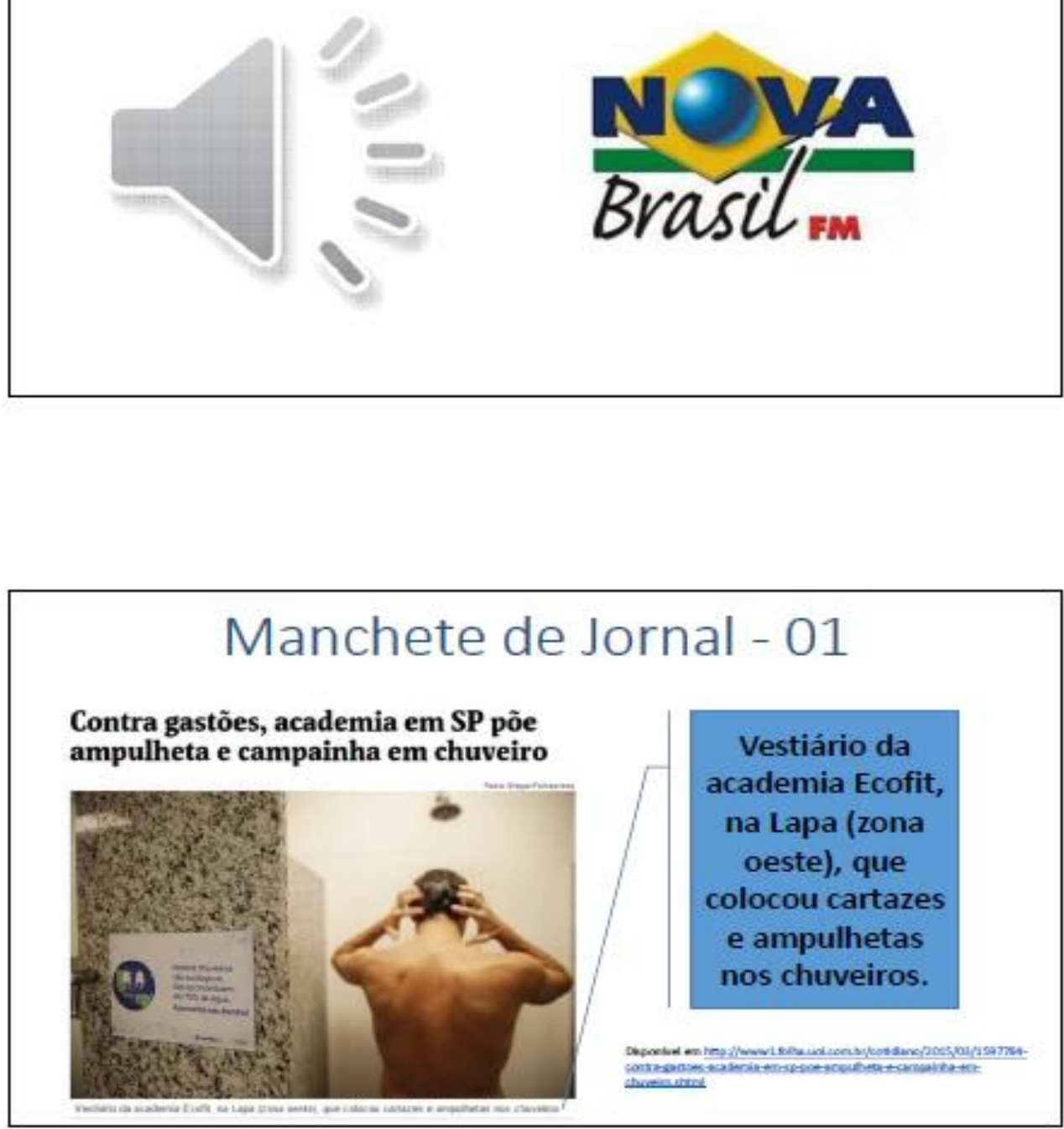


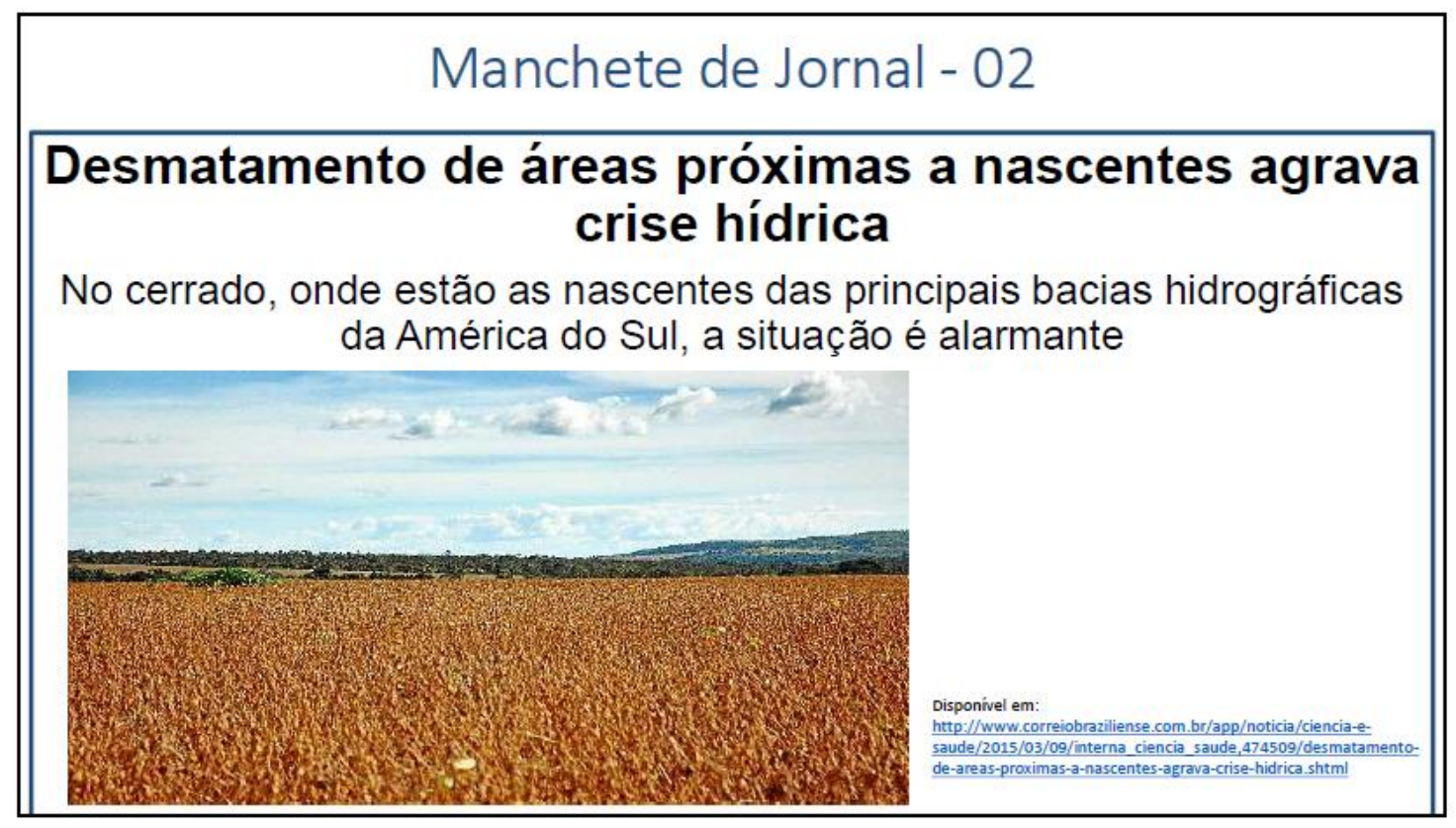




\section{INSTITUTO FEDERAL}

BRASILIA

Campus São Sebastião

Instituto Federal de Educação, Ciência e Tecnologia de Brasília - Campus São Sebastião. Curso de Técnico em Secretariado Escolar Turma:

Professora: Maria Eneida

Componente Curricular: Leitura e Produção de Textos

Aluno:

Data: $/ 2015$.

\section{Atividade de Leitura e Produção de Textos}

Valor: 2,0 pontos

A partir do assunto abordado no texto, das discussões realizadas anteriormente e das relações do tema "Crise Hídrica" com sua realidade, redija um ou mais parágrafos que demonstre(m) sua reflexão crítica acerca desse tema. 


\section{Termo de Consentimento Livre e Esclarecido}

Você está sendo convidado para participar da pesquisa Atividades de Produção e Compreensão Textual no Ensino Técnico: Estudo Socionteracional da Referenciação e Inferenciação. Sua participação é voluntária, não obrigatória. A qualquer momento, você pode desistir de participar e retirar seu consentimento. Sua recusa não trará nenhum prejuízo em sua relação com o pesquisador ou com a instituição. Não há riscos envolvidos para os participantes da pesquisa, o principal benefício da sua participação é ampliar seu conhecimento de mundo e o conhecimento enciclopédico por meio das atividades de leitura e compreensão textual que serão propostas nas aulas. $O$ objetivo desta pesquisa é compreender como ocorre o processo de referenciação/inferenciação na produção de textos escritos e orais em atividades de produção/compreensão textual, bem como avaliar suas implicações na construção do letramento escolar. Durante a geração de dados, serão utilizadas filmagens captadas durante as interações, que serão convertidas em arquivos MP4 e AVI.

As informações obtidas através dessa pesquisa serão confidenciais e será mantido sigilo sobre sua participação. Os dados não serão divulgados de modo que permitam a sua identificação (seu nome será trocado na pesquisa e os vídeos não serão divulgados). Sua identidade não será divulgada sob qualquer hipótese. Não haverá nenhuma forma de devolução dos dados. A pesquisa é revisada eticamente pela Plataforma Brasil (www.saude.gov.br/plataformabrasil, plataformabrasil@saude.gov.br)

Você receberá uma cópia deste termo e será esclarecido(a) sobre a pesquisa em qualquer aspecto que desejar.

\footnotetext{
Alinne Santana Ferreira

E-mail da pesquisadora: linne.one@gmail.com

E-mail do Comitê de ética em pesquisa em Seres Humanos da Universidade de Brasília - CEP/lH: cep ih@unb.br

Declaro que entendi os objetivos, riscos e benefícios de minha participação na pesquisa e concordo em participar.
} 


\section{TERMO DE CESSÃO DE DIREITO DE USO DA IMAGEM}

$\mathrm{Eu}$, , portador da carteira de identidade número - (órgão emissor e Unidade da Federação), autorizo o uso de minha imagem para colaboração na pesquisa: Atividades de Produção e Compreensão Textual no Ensino Técnico: Estudo Socionteracional da Referenciação e Inferenciação.

(NOME) 